JURNAL ALPHAEUCLIDEDU

JURNAL KEILMUAN MATEMATIKA DAN PENDIDIKAN MATEMATIKA

\author{
SURAT KEPUTUSAN DEKAN FKIP UNIVERSITAS TANJUNGPURA \\ NOMOR : 2922/UN22.6/PI/2021 TANGGAL 1 JULI 2021
}

\author{
Pelindung: \\ Dekan FKIP Universitas Tanjungpura \\ Penanggung Jawab: \\ Unit Penelitian Pengembangan Penerbitan dan Publikasi Ilmiah (UP4I) \\ FKIP Untan \\ Pemimpin Redaksi (Editorial In Chief) \\ Dr. Dede Suratman, M.Si \\ Sekretaris Redaksi (Managing Editorial) \\ Dona Fitriawan, M.Pd
}

Editor (Section Editorial)

1. Prof. Dr. Nanang Priatna, M.Pd (Universitas Pendidikan Indonesia)

2. Prof. Dr. Suradi, M.S

(Universitas Negeri Makassar)

3. Drs. Asep Nursangaji, M.Pd

(Universitas Tanjungpura)

4. Dr. Sugiatno, M.Pd

(Universitas Tanjungpura)

5. Dr. Mohamad Ri'fat, M.Pd

(Universitas Tanjungpura)

6. Dr. Hamdani, M.Pd

(Universitas Tanjungpura)

7. Fredi Ganda Putra, M.Pd

(UIN Raden Intan Lampung)

8. Dr. Nurfadilah Siregar, M.Pd

(Universitas Tanjungpura)

9. Revi Lestari Pasaribu, M.Si

(Universitas Tanjungpura)

Penyunting Ahli (Reviewers)

1. Prof. Dr. Toto Nusantara, M.Si (Universitas Negeri Malang)

2. Prof. Dr. Edy Sahputra, M.Pd

3. Prof. Dr. Heris Hendriana, M.Pd

(Universitas Negeri Medan)

4. Dr. Yulis Jamiah, M.Pd

5. Dr. Agung Hartoyo, M.Pd

(IKIP Siliwangi)

(Universitas Tanjungpura)

6. Drs. Edy Yusmin, M.Pd

(Universitas Tanjungpura)

7. Drs. Ade Mirza, M.Pd

(Universitas Tanjungpura)

8. Dr. Bistari, M.Pd

(Universitas Tanjungpura)

(Universitas Tanjungpura)

9. Drs. Dian Ahmad, M.Pd

(Universitas Tanjungpura)

10. Drs. Romal Ijuddin, M.Pd

(Universitas Tanjungpura) 


\section{PENGANTAR}

Puji syukur Kami haturkan kehadirat Tuhan Yang Maha Esa, atas terbitnya Jurnal Pendidikan Matematika yang bernama Jurnal AlphaEuclidEdu pada edisi Desember 2021. Jurnal AlphaEuclidEdu mencakup bidang matematika dan pendidikan matematika dengan rincian: 1) Belajar dan Pembelajaran Matematika ;2) Media dan Sumber Belajar Matematika; 3) Kurikulum Matematika; 4) Evaluasi Pembelajaran Matematika; 5) Profesi Pendidik Matematika; 6) Matematika Untuk Ekonomi; 7) Statistika; 8) Geometri; 9) Aljabar; 10) Analisis; 11) Kalkulus; 12) Trigonometri; 13) Operasi Riset.

Jurnal AlphaEuclidEdu diterbitkan oleh Program Studi Pendidikan Matematika yang diprakasai oleh UP4I (Unit Penelitian Pengembangan Penerbitan dan Publikasi Ilmiah) FKIP Universitas Tanjungpura. Tentunya juga jurnal ini diterbitkan atas partisipasi semua pihak yang turut berkonstribusi, khususnya para penulis yang telah mempercayakan tulisannya dimuat pada jurnal ini. Terbitnya jurnal ini merupakan berkat kerja sama yang baik para Tim Editor dan Para Reviewer.

Kami percaya bahwa Tuhan Yang Maha Esa senantiasa membalas semua kebaikan yang dilakukan semua pihak dalam atensinya sebagai amal bakti untuk memajukan kualitas pendidikan serta mengembangkan kebiasan menulis dalam nuansa ilmiah. Akhirnya, kami berharap kritik dan saran yang bermanfaat agar jurnal ini mampu memberikan konstribusi yang lebih baik di masa mendatang.

Pontianak, 28 Desember 2021

\section{Tim Editor}




\section{DAFTAR ISI}

Volume 2, Nomor 2, Desember 2021

COVER

SURAT KEPUTUSAN .

PENGANTAR

DAFTAR ISI

PEMBELAJARAN PROBLEM POSING SETTING KOOPERATIF UNTUK MENINGKATKAN BERFIKIR KREATIF.

Asmidi

$\begin{array}{lrlrlr}\text { MENGATASI } & \text { HAMBATAN } & \text { BELAJAR } & \text { DALAM } & \text { MATERI } & \text { PLSV } \\ \text { MENGGUNAKAN } & \text { DESAIN } & \text { DIDAKTIS } & \text { DENGAN } & \text { SCAFFOLDING }\end{array}$

Ari Ariansyah, Sugiatno, Bistari

EKSPLORASI SIKAP MAHASISWA PENDIDIKAN MATEMATIKA DALAM PEMBELAJARAN MATEMATIKA

Yulis Jamiah

KAJIAN ETNOMATEMATIKA DALAM TRADISI PERNIKAHAN MASYARAKAT DAYAK KANAYATN DI KECAMATAN TOHO KABUPATEN MEMPAWAH

Eka, Sugiatno, Munaldus

ANALISIS LITERASI NUMERASI PADA MATERI PERSAMAAN DAN PERTIDAKSAMAAN NILAI MUTLAK LINEAR SATU VARIABEL DIKAJI DARI KECERDASAN EMOSIONAL

Esa Sandi Putri, Edy Yusmin, Asep Nursangaji

PENGEMBANGAN BLOG PEMBELAJARAN MATEMATIKA MATERI PECAHAN DI SEKOLAH MENENGAH PERTAMA .

Ignasius Layola Dedy, Dede Suratman, Munaldus

PENGARUH PENDEKATAN REALISTIC MATHEMATIC EDUCATION (RME) TERHADAP HASIL BELAJAR PESERTA DIDIK DALAM MATERI LINGKARAN DI SMA PANCA SETYA SINTANG

Vonia Yulia Agustina, Ahmad Yani T, Romal Ijuddin

PENERAPAN MODEL PEMBELAJARAN STRUCTURE NUMBERED HEADS MATERI OPERASI HITUNG BILANGAN PECAHAN MTs AL-FATHAANAH MAMPAWAH HILIR 
PROSES BERFIKIR SISWA DALAM MEMECAHKAN MASALAH SISTEM PERSAMAAN LINEAR TIGA VARIABEL BERDASARKAN GAYA KOGNITIF DI SMK

Dea Angella, Edy Yusmin, Dian Ahmad

ANALISIS KONSEP MATEMATIKA SEKOLAH DALAM PEMULASARAAN JENAZAH

Tsamara Banafsaj, Ahmad Yani T, Asep Nursangaji

ANALISIS GAYA BELAJAR VISUAL DITINJAU DARI KEMAMPUAN PEMECAHAN MASALAH SISTEM PERSAMAAN LINEAR DUA VARIABEL

Aribah Errina, Mohamad Rif'at, Silvia Sayu

IMPLEMENTASI MOODLE SEBAGAI MEDIA PEMBELAJARAN JARAK JAUH

Indah Nopita Sari, Annisa Prima Exacta

POTENSI PESERTA DIDIK TIPE QUITTER MENYELESAIKAN SOAL OPENENDED MATERI SEGIEMPAT DAN SEGITIGA

Natalia, Sugiatno, Silvia Sayu

IDENTIFIKASI MISKONSEPSI DALAM MENYELESAIKAN SOAL PERTIDAKSAMAAN LINEAR SATU VARIABEL YANG MEMUAT NILAI MUTLAK 
Vol 2 No 2 Desember 2021

Jurnal AlphaEuclidEdu

Received: 25/10/2021; Resived: 11/11/2021; Accepted: 27/12/2021

\title{
PEMBELAJARAN PROBLEM POSING SETTING KOOPERATIF UNTUK MENINGKATKAN BERPIKIR KREATIF
}

\author{
*Asmidi \\ SMP Negeri 3 Simpang Hilir, Kabupaten Kayong Utara \\ asmidi100@gmail.com
}

\begin{abstract}
Penelitian ini bertujuan untuk mendeskripsikan pembelajaran problem posing setting kooperatif untuk meningkatkan berpikir kreatif siswa kelas IX SMP Negeri 1 Sukadana Pada Materi Tabung dan Kerucut. Jenis penelitian ini adalah penelitian tindakan kelas (PTK). Data yang dikumpulkan berupa hasil tes akhir siklus siswa. Langkah-langkah pembelajaran problem posing setting kooperatif pada materi tabung dan kerucut yaitu : 1) menyampaikan tujuan pembelajaran, memotivasi siswa, mengeksplorasi kemampuan awal siswa, menyampaikan materi pelajaran, dan memberikan contoh membuat soal sekaligus selesaianya dengan media tayang slide, 2) mengorganisasikan siswa kedalam kelompok-kelompok belajar yang bersifat heterogen berdasarkan kemampuan dan jenis kelamin yang beranggotakan 4 sampai 5 siswa, 3) meminta siswa untuk mengajukan soal sebanyak mungkin berdasarkan informasi gambar tabung dan kerucut yang disajikan dalam LKPD, 4) meminta siswa untuk saling bertukar soal sekaligus menyelesaikan soal yang telah dibuat oleh kelompok lain, kemudian siswa diminta untuk mengembalikan soal tersebut pada kelompok asal untuk di koreksi, 5) meminta siswa untuk mempresentasikan hasil kerja kelompoknya, 6) meminta siswa untuk membuat soal sebanyak-banyaknya sekaligus selesaiannya berdasarkan informasi gambar tabung dan kerucut secara individu. Kemampuan berpikir kreatif siswa setelah penerapan pembelajaran problem posing setting kooperatif pada penelitian ini meningkat dari kategori "cukup baik" menjadi kategori "baik". Skor kemampuan berpikir kreatif siswa dalam pembelajaran problem posing setting kooperatif pada siklus ke-1 sebesar 43 berada pada kategori "cukup baik" dan pada siklus ke-2 sebesar 65 berada pada kategori "baik”. Ini berarti terjadi peningkatan skor kemampuan berpikir siswa dari siklus ke-1 ke siklus ke-2 sebesar 22.

Keyword: Problem Posing, Pembelajaran Kooperatif, Berpikir Kreatif
\end{abstract}

\section{Pendahuluan}

Belajar matematika yang dilakukan siswa tidak sekedar mengingat materi yang telah disampaikan guru saat pembelajaran dikelas. Siswa harus memiliki banyak ide, gagasan, dan kreatifitas dalam menyelesaikan permasalahan matematika. Memiliki banyak ide dan gagasan sangat dibutuhkan dalam menyelesaikan masalah dalam matematika agar siswa tidak mudah menyerah dan putus asa. Memiliki kreatifitas menjadikan siswa lebih kreatif dalam menemukan solusi dari permasalahan. Silver (1997) mengungkapkan bahwa pelajaran matematika sangat berhubungan dengan kreatifitas.

Berpikir kreatif merupakan unsur penting yang dapat menumbuhkan dan mengembangkan kreatifitas siswa dalam belajar matematika. Siswa yang berpikir kreatif akan lebih mampu untuk mengolah berbagai informasi yang diperolehnya dari berbagai sumber belajar. Kemampuan berpikir kreatif juga dapat mendorong siswa untuk menyampaikan dan mengungkapkan berbagai ide dan gagasan yang dimilikinya dalam menyelesaikan soal matematika yang memiliki jawaban dengan berbagai alternatif penyelesaian. Oleh karena itu cara berpikir kreatif dapat dikembangkan melalui pendidikan matematika (Siswono : 2004).

Kenyataannya berpikir kreatif belum menjadi perhatian yang serius oleh guru. Bahar \& Maker (2011) menyatakan bahwa guru di tingkat dasar dan menengah belum menyadari pentingnya berpikir kreatif dan pemecahan masalah dalam matematika. Berdasarkan pengalaman penulis, guru belum maksimal mengeksplorasi kemampuan 
Vol 2 No 2 Desember 2021

Jurnal AlphaEuclidEdu

Received: 25/10/2021; Resived: 11/11/2021; Accepted: 27/12/2021

siswa dalam menyampaikan materi pelajaran. Guru belum maksimal memberikan kesempatan kepada siswa untuk mengungkapkan ide dan gagasannya. Guru belum melibatkan siswa secara aktif belajar secara berkelompok. Sehingga kemampuan berpikir kreatif siswa rendah.

Salah satu cara yang dapat dilakukan untuk meningkatkan berpikir kreatif siswa adalah dengan mengajukan masalah (problem posing). Silver (1997) menyatakan bahwa salah satu kegiatan yang dapat mengembangkan kreativitas siswa adalah kegiatan pengajuan masalah (problem posing). Mengajukan permasalahan dalam pembelajaran matematika menekankan pada aktivitas siswa untuk membuat soal sekaligus menyelesaikannya. Hal ini sejalan dengan Siswono (2004) menyatakan bahwa pengajuan masalah (problem posing) dalam pembelajaran intinya meminta siswa untuk mengajukan soal atau masalah. Lebih lanjut Siswono menjelaskan bahwa latar belakang masalah dapat berdasar topik yang luas, soal yang sudah dikerjakan atau informasi tertentu yang diberikan guru kepada siswa.

Silver (dalam Silver \& Cai, 1996) memberikan istilah pengajuan soal (problem posing) diaplikasikan pada tiga bentuk aktivitas kognitif matematika yang berbeda, yaitu: 1) pengajuan pre-solusi (presolution posing) yaitu seorang siswa membuat soal dari situasi yang diadakan, 2) pengajuan didalam solusi (within-solution posing), yaitu seorang siswa merumuskan ulang soal seperti yang telah diselesaikan, dan 3) pengajuan setelah solusi (post solution posing), yaitu seorang siswa memodifikasi tujuan atau kondisi soal yang sudah diselesaikan untuk membuat soal yang baru.

Untuk meningkatkan aktivitas belajar siswa secara aktif dapat dilakukan dengan menerapkan model pembelajaran kooperatif. Dalam pembelajaran kooperatif memberikan kesempatan kepada siswa saling berinteraksi dalam menyelesaikan tugas kelompok yang merupakan tanggung jawab seluruh anggota kelompok. Selain itu pembelajaran kooperatif dapat meningkatkan prestasi belajar siswa. Slavin (dalam Isjoni, 2013), pembelajaran kooperatif adalah suatu model pembelajaran dimana siswa belajar dan bekerja dalam kelompok-kelompok kecil secara kolaboratif yang anggotanya antara 4-6 orang dengan struktur kelompok heterogen.

Pembelajaran kooperatif merupakan strategi belajar dengan sejumlah siswa sebagai anggota kelompok kecil yang tingkat kemampuannya berbeda. Dalam menyelesaikan tugas kelompoknya, setiap siswa harus saling bekerja sama dan saling membantu untuk memahami materi pelajaran. Menurut Slavin (dalam Isjoni, 2013:15), pembelajaran kooperatif adalah suatu model pembelajaran dimana siswa belajar dan bekerja dalam kelompok-kelompok kecil secara kolaboratif yang anggotanya antara 4-6 orang dengan struktur kelompok heterogen. Maksud kelompok heterogen adalah kelompok yang terdiri dari campuaran tingkat kemampuan siswa, jenis kelamin, dan suku. Hal ini bermanfaat untuk melatih siswa untuk menerima perbedaan dan bekerja dengan teman yang berlatar belakang berbeda. Menurut Parker (dalam Huda, 2011), mendefinisikan kelompok kecil sebagai suasana pembelajaran dimana para siswa saling berinteraksi dalam kelompok- 
Vol 2 No 2 Desember 2021

Jurnal AlphaEuclidEdu

Received: 25/10/2021; Resived: 11/11/2021; Accepted: 27/12/2021

kelompok kecil untuk mengerjakan tugas akademik demi mencapai tujuan bersama.

Tujuan yang paling penting dari pembelajaran kooperatif menurut Slavin (2008:33) adalah untuk memberikan para siswa pengetahuan, konsep, kemampuan, dan pemahaman yang mereka butuhkan supaya menjadi anggota masyarakat yang bahagia dan memberikan kontribusi.

Keunggulan dalam pembelajaran kooperatif yang dikemukakan oleh Jarolimek \& Parker (dalam Isjoni, 2013:36) adalah: 1) saling ketergantungan yang positif, 2) adanya pengakuan dalam merespon perbeddaan individu, 3) siswa dilibatkan dalam perencanaan dan pengelolaan kelas, 4) suasana kelas yang rileks dan menyenangkan, 5) terjalinnya hubungan yang hangat dan bersahabat antara siswa dengan guru, 6) memiliki banyak kesempatan untuk mengekspresikan pengalaman emosi yang menyenangkan.

Problem posing didefinisikan sebagai kegiatan siswa dalam membuat masalah dan sekaligus pemecahannnya, English, NCTM 2000, Silver \& Cai (dalam Christou dkk, 2005). Menurut Leung (dalam Kar dkk, 2010) problem posing adalah mengorganisasikan masalah baru yang diberikan. English, Cai, dan Hwang 2002 (dalam Kar dkk, 2010) mendefinisikan problem posing sebagai restrukturisasi dari masalah saat ini. Selanjutnya problem posing juga diartikan sebagai pembentukan soal berdasarkan konteks, cerita, informasi atau gambar yang diketahui (Lin, 2004).

Problem posing dalam matematika mempunyai beberapa arti menurut Suryanto (dalam Permana 2010) yaitu: a) perumusan soal sederhana atau perumusan ulang soal yang ada dengan beberapa perubahan agar lebih sederhana dan dapat dikuasai, b) perumusan soal yang berkaitan dengan syarat-syarat pada soal yang telah diselesaikan dalam rangka pencarian alternatif pemecahan atau alternatif soal yang relevan, dan c) perumusan soal atau pembentukan soal dari suatu situasi yang tersedia, baik dilakukan sebelum, saat atau setelah pemecahan suatu masalah/soal.

Silver dan Cai (dalam Pittalis dkk, 2004) mengklasifikasikan tiga aktifitas kognitif dalam Problem Posing, yaitu: (1) Pre-solution Posing yaitu pengajuan soal berdasarkan situasi atau informasi yang diberikan, (2) Within-solution Posing yaitu pengajuan atau formulasi soal yang sedang diselesaikan, (3) Post-solution Posing; strategi ini disebut juga strategi "find a more challenging problem".

Pembelajaran problem posing setting kooperatif merupakan pembelajaran yang mengelompokan siswa kedalam tim-tim kecil agar saling belajar satu sama lainnya untuk merumuskan atau pembentukan soal dan sekaligus menyelesaikannya. Siswa diberikan informasi tentang materi pelajaran dan contoh tentang cara perumusan atau pembuatan soal dalam pembelajaran problem posing secara kelompok. Selanjutnya guru memberikan bimbingan dan arahan kepada kelompok yang menemukan kesulitan dalam merumuskan atau pembuatan soal. Siswa yang sudah mengerti diarahkan untuk membantu teman lain dalam kelompoknya.

Fase-fase pembelajaran problem posing setting kooperatif disertai prilaku guru dalam penelitian ini dapat dilihat pada tabel berikut : 
Vol 2 No 2 Desember 2021

Jurnal AlphaEuclidEdu

Received: 25/10/2021; Resived: 11/11/2021; Accepted: 27/12/2021

Tabel 1. Sintak Pembelajaran Problem Posing Setting Kooperatif

\begin{tabular}{cl}
\hline Fase-fase & \multicolumn{1}{c}{ Perilaku guru } \\
Fase 1 & $\begin{array}{l}\text { Menyampaikan tujuan pembelajaran } \\
\text { Menyampaikan apersepsi } \\
\text { Menyampaikan Informasi } \\
\text { Menyampaikan materi pelajaran } \\
\text { Memberikan contoh pengajuan soal sekaligus selesaiaanya }\end{array}$ \\
\hline Fase 2 & $\begin{array}{l}\text { Mengelompokan siswa kedalam tim-tim belajar yang beranggotakan 4- } \\
\text { 5 orang yang besifat heterogen berdasarkan kemampuan, dan jenis } \\
\text { kelamin }\end{array}$ \\
\hline Pembentukan Kelompok \\
Fengajukan Masalah. & Meminta siswa untuk mengajukan masalah dalam kelompok belajar \\
\hline Fase 4 & $\begin{array}{l}\text { Meminta siswa untuk bertukar masalan dengan kelompok lain dan } \\
\text { menyelesaikan masalah dari kelompok asal }\end{array}$ \\
\hline Fresentasi Kelompok & Meminta siswa untuk mempresentasikan hasil kerja kelompoknya \\
\hline Fase 6 & Mengevalusi, merefleksi kegiatan pembelajaran \\
\hline Mengevaluasi &
\end{tabular}

Ciri-ciri kemampuan berpikir kreatif menurut Munandar (dalam Azhari \& Somakim, 2013) antara lain meliputi : 1) keterampilan berpikir lancar, yaitu: menghasilkan banyak gagasan/jawaban yang relevan, menghasilkan motivasi belajar, dan arus pemikiran lancar. 2) keterampilan berpikir lentur (fleksibel), yaitu: menghasilkan gagasan-gagasan yang seragam, mampu mengubah cara atau pendekatan, arah pemikiran yang berbeda. 3) keterampilan berpikir orisinil, yaitu: meberikan jawaban yang tidak lazim, memberkan jawaban yang lain daripada yang lain, memberikan jawaban yang jarangdiberikan kebanyakan orang. 4) keterampilan berpikir terperinci (elaborasi), yaitu: mengembangkan, menambah, memperkaya suatu gagasan, memperinci detail-detail, memperluas suatu gagasan.

Kreatifitas siswa dapat dinilai menggunakan acuan yang dibuat Silver (1997) yang meliputi tiga komponen utama kreativitas yaitu:

Tabel. 2. Komponen Kreatifitas

\begin{tabular}{cl}
\hline Komponen Kreativitas & \multicolumn{1}{c}{ Pengajuan Masalah } \\
\hline Kefasihan/fluency & $\begin{array}{l}\text { Siswa membuat banyak masalah yang dapat dipecahkan. } \\
\text { swa berbagi masalah yang diajukan. }\end{array}$ \\
\hline Fleksibilitas/flexibility & $\begin{array}{l}\text { Siswa mengajukan masalah yang dapat dipecahkan dengan cara-cara } \\
\text { yang berbeda. }\end{array}$ \\
$\begin{array}{l}\text { Siswa menggunakan pendekatan "bagaimana jika tidak?" untuk } \\
\text { mengajukan masalah. }\end{array}$ \\
\hline Kebaruan/novelty & $\begin{array}{l}\text { Siswa memeriksa beberapa masalah yang diajukan kemudian } \\
\text { mengajukan suatu masalah yang berbeda. }\end{array}$ \\
\hline
\end{tabular}

\section{Metode Penelitian}

Penelitian ini merupakan penelitian tindakan kelas (classroom action research) karena penelitian dilakukan dikelas untuk meningkatkan kualitas pembelajaran, ini sejalan dengan Arikunto (2014:58) penelitian tindakan kelas (PTK) adalah penelitian tindakan (action research) yang dilakukan dengan tujuan memperbaiki mutu praktik pembelajaran dikelas. Partisipan penelitian ini adalah 25 siswa kelas IXC SMP Negeri 1 
Vol 2 No 2 Desember 2021

Jurnal AlphaEuclidEdu

Received: 25/10/2021; Resived: 11/11/2021; Accepted: 27/12/2021

Sukadana.

Rancangan penelitian tindakan ini mengacu pada model yang dikembangkan oleh Kemmis dan Taggart yang terdiri dari empat komponen tindakan yakni, perencanaan, tindakan, observasi, dan refleksi. Tahapan-tahan dalam penelitian ini adalah: 1) observasi awal, pada tahap ini dilakukan wawancara terhadap siswa, analis hasil belajar siswa untuk mengidentifikasi masalah yang ada dikelas, 2) perencanaan tindakan, pada tahap ini menyiapkan rencana pelaksanaan pembelajaran (RPP), lembar kerja peserta didik (LKPD), lembar tes pada akhir tiap siklus, lembar observasi terhadap pelaksanaan pembelajaran dan aktivitas siswa, format wawancara, 3) pelaksanaan tindakan, pada tahap ini dilaksanakan pembelajaran sesuai dengan rencana yang telah disusun pada tahap perencanaan.

Data yang dikumpulkan dalam penelitian ini adalah hasil tes berpikir kreatif siswa pada setiap akhir siklus pembelajaran. Hasil tes tersebut dianalisis dengan teknik analisis data kualitatif. Proses analisis dilakukan dari dengan tahapan-tahapan analisis sebagai berikut: 1) mereduksi data dilakukan dengan menyeleksi, memfokuskan, dan menyederhanakan semua data mentah dan kasar yang diperoleh, 2) penyajian data dilakukan dengan menyajikan hasil reduksi data secara naratif sehingga memungkinkan penarikan kesimpulan dan keputusan pengambilan tindakan, dan 3) penarikan kesimpulan dilakukan dengan memberikan simpulan terhadap hasil penafsiran dan evaluasi.

Penelitian ini dikatakan berhasil jika kategori kemampuan berpikir kreatif siswa sudah meningkat. Terdapat peningkatan kategori apabila kemampuan berpikir kreatif siswa meningkat dari suatu kategori ke kategori diatasnya. Misalnya dari kategori tidak baik menjadi kurang baik atau diatasnya, dari kategori kurang baik menjadi kategori cukup baik, atau diatasnya, dan seterusnya. Selain itu hasil observasi aktivitas siswa dan aktivitas guru termasuk kategori baik atau sangat baik.

\section{Hasil dan Pembahasan}

3.1 Hasil

Siklus 1

Pada siklus ke-1 dilakukan 3 kali pertemuan yaitu 2 kali pembelajaran problem posing setting kooperatif dan 1 kali tes akhir siklus. Alokasi waktu untuk 1 kali pertemuan adalah 2 x 40 menit. Materi pembelajaran problem posing setting kooperatif pada pertemuan pertama adalah luas permukan tabung, pertemuan kedua pada materi volume tabung, Tes akhir siklus ke-1 dilaksanakan pada pertemuan ketiga.

Tes akhir siklus ke-1 diikuti oleh 25 siswa dari 31 siswa kelas IXC. Adapun hasil tes berpikir kreatif siswa pada siklus ke-1 disajikan pada tabel berikut ini:

Tabel 3. Persentasi Hasil Tes Siklus Ke-1

\begin{tabular}{cccc}
\hline No & Kriteria & Jumlah Siswa & Persentasi \\
\hline 1 & Tidak Baik & 2 & $8 \%$ \\
\hline 2 & Kurang Baik & 14 & $56 \%$ \\
\hline 3 & Cukup Baik & 0 & $0 \%$ \\
\hline
\end{tabular}


Vol 2 No 2 Desember 2021

Jurnal AlphaEuclidEdu

Received: 25/10/2021; Resived: 11/11/2021; Accepted: 27/12/2021

\begin{tabular}{cccc}
\hline 4 & Baik & 8 & $32 \%$ \\
\hline 5 & Sangat Baik & 1 & $4 \%$ \\
\hline
\end{tabular}

Berdasarkan tabel diatas, hasil tes akhir tindakan siklus ke-1 yang berupa skor kemampuan berpikir kreatif siswa adalah $13 \%$ siswa termasuk kategori tidak baik, $20 \%$ siswa termasuk kategori kurang baik, $40 \%$ siswa termasuk kategori cukup baik, $27 \%$ termasuk kategori baik, dan 3\% siswa termasuk kategori sangat baik. Hasil analisis skor tes kemampuan berpikir kreatif siswa sebesar 48 termasuk kategori cukup baik.

Berdasarkan refleksi yang dilakukan diketahui bahwa masih ada siswa yang belum mampu membuat soal dengan benar sekaligus selesaiannya. Ada siswa yang sudah mampu membuat soal dengan benar tetapi belum mampu menyelesaikannya. Peneliti juga menyadari bahwa pembelajaran Problem Posing pada siklus ke-1 masih banyak terdapat kelemahan. Adapun kelemahan-kelemahan yang terjadi pada tindakan siklus I disajikan dalam tabel berikut.

Tabel 4. Tabel Kelemahan Tindakan Siklus I dan Perbaikan Tindakan Siklus II

\begin{tabular}{clll}
\hline No & \multicolumn{1}{c}{ Kelemahan } & \multicolumn{1}{c}{ Penyebab } & \multicolumn{1}{c}{ Rencana Perbaikan } \\
\hline 1 & $\begin{array}{l}\text { Siswa kurang dilibatkan } \\
\text { dalam pemberian contoh } \\
\text { pembuatan soal. }\end{array}$ & $\begin{array}{l}\text { Guru hanya terpaku pada } \\
\text { beberapa siswa yang aktif } \\
\text { saja. }\end{array}$ & $\begin{array}{l}\text { Meningkatkan aktivitas } \\
\text { siswa saat pemberian } \\
\text { contoh pembuatan soal. }\end{array}$ \\
\hline 2 & $\begin{array}{l}\text { Siswa belum berdiskusi } \\
\text { secara maksimal dengan } \\
\text { temannya. }\end{array}$ & $\begin{array}{l}\text { Siswa belum terbiasa belajar } \\
\text { dengan metode diskusi. }\end{array}$ & $\begin{array}{l}\text { Meningkatkan kerjasama } \\
\text { sesama siswa. }\end{array}$ \\
\hline 3 & $\begin{array}{l}\text { Masih ada siswa yang } \\
\text { memerlukan waktu yang } \\
\text { cukup lama dalam membuat } \\
\text { dan menyelesaikan soal. }\end{array}$ & Siswa kurang menguasai \\
& materi. & $\begin{array}{l}\text { Memberikan bimbingan } \\
\text { kepada siswa yang } \\
\text { mengalami kesulitan } \\
\text { membuat dan } \\
\text { menyelesaikan soal. }\end{array}$ \\
\hline 4 & $\begin{array}{l}\text { Siswa kurang } \\
\text { mengungkapkan } \\
\text { permasalahan yang } \\
\text { dihadapinya. }\end{array}$ & $\begin{array}{l}\text { Siswa belum terbiasa untuk } \\
\text { mengungkapkan } \\
\text { permasalahannya kepada guru. }\end{array}$ & $\begin{array}{l}\text { Meningkatkan perhatian } \\
\text { pada siswa yang masih } \\
\text { malu bertanya. }\end{array}$ \\
\hline $\begin{array}{l}\text { Pembelajaran melebihi } \\
\text { alokasi waktu yang } \\
\text { ditentukan. }\end{array}$ & $\begin{array}{l}\text { Siswa terlalu lama pada } \\
\text { kegiatan pembuatan soal dan } \\
\text { mengerjakan soal. }\end{array}$ & $\begin{array}{l}\text { Memberi batas waktu dalam } \\
\text { pembuatan soal dan } \\
\text { pengerjaan soal. }\end{array}$ \\
\hline
\end{tabular}

Berdasarkan tabel diatas, hasil tes akhir tindakan siklus ke-1 yang berupa skor kemampuan berpikir kreatif siswa adalah 8\% siswa termasuk kategori "tidak baik", 56\% siswa termasuk kategori "kurang baik", 0\% siswa termasuk kategori "cukup baik", 32\% termasuk kategori "baik", dan 4\% siswa termasuk kategori "sangat baik". Hasil analisis skor tes kemampuan berpikir kreatif siswa sebesar 43 termasuk kategori "cukup baik".

Berdasarkan hasil refleksi terhadap tindakan siklus ke-1 ditemukan beberapa kelemahan saat pembelajaran problem posing setting kooperatif pada materi luas permukaan dan volume tabung. Kelemahan-kelemahan yang terjadi pada tindakan siklus ke-1 adalah sebagai berikut : 
Vol 2 No 2 Desember 2021

Jurnal AlphaEuclidEdu

Received: 25/10/2021; Resived: 11/11/2021; Accepted: 27/12/2021

1. Guru belum melibatkan siswa secara aktif saat contoh pengajuan soal sekaligus selesaiannya.

2. Masih ada siswa yang kurang terlibat saat diskusi kelompok.

3. Masih ada siswa yang belum mampu mengungkapkan masalah yang dihadapinya terkait pengajuan soal dan mencari jawabannya.

4. Masih ada siswa yang kesulitan dalam mengajukan soal dan menjawan soal, sehingga melebihi alokasi waktu yang ditentukan.

5. Alokasi waktu pembelajaran melebihi dari alokasi waktu yang telah ditetapkan dalam RPP.

Adapun rencana perbaikan yang akan dilakukan pada siklus ke-2 terhadap kelemahan-kelemahan yang terdapat pada siklus ke-1 adalah sebagai berikut :

1. Guru meningkatkan aktifitas siswa saat pengajuan soal sekaligus selesaiannya.

2. Siswa diminta untuk meningkatkan kerjasama saat diskusi kelompok.

3. Guru meningkatkan perhatiannya terhadap siswa yang belum mampu mengungkapkan masalah yang dihadapinya.

4. Mengarahkan siswa untuk memperhatikan alokasi waktu yang telah ditetapkan.

5. Guru dan siswa harus memperhatikan alokasi waktu yang telah ditentukan.

Siklus 2

Pada siklus ke-2 dilakukan 3 kali pertemuan yaitu 2 kali pembelajaran problem posing setting kooperatif dan 1 kali tes akhir siklus. Alokasi waktu untuk 1 kali pertemuan adalah 2 x 40 menit. Materi pembelajaran problem posing setting kooperatif pada pertemuan pertama adalah luas permukan kerucut, pertemuan kedua pada materi volume kerucut, Tes akhir siklus ke-2 dilaksanakan pada pertemuan ketiga. Tes akhir siklus ke-2 diikuti oleh 25 siswa dari 31 siswa kelas IXC. Adapun hasil tes berpikir kreatif siswa pada siklus ke-2 disajikan pada tabel berikut ini :

Tabel 5. Persentasi Hasil Tes Siklus Ke-2

\begin{tabular}{cccc}
\hline No & Kriteria & Jumlah Siswa & Persentasi \\
\hline 1 & Tidak Baik & 0 & $0 \%$ \\
\hline 2 & Kurang Baik & 3 & $12 \%$ \\
\hline 3 & Cukup Baik & 0 & $0 \%$ \\
\hline 4 & Baik & 19 & $76 \%$ \\
\hline 5 & Sangat Baik & 3 & $12 \%$ \\
\hline
\end{tabular}

Berdasarkan tabel di atas, hasil tes akhir tindakan siklus ke-2 yang berupa skor kemampuan berpikir kreatif siswa adalah 0\% siswa termasuk kategori "tidak baik", $0 \%$ siswa termasuk kategori "kurang baik", 12\% siswa termasuk kategori "cukup baik", 76\% termasuk kategori "baik", dan 12\% siswa termasuk kategori "sangat baik". Hasil analisis skor tes kemampuan berpikir kreatif siswa sebesar 65 termasuk kategori "baik".

Berdasarkan hasil analisis data yang diuraikan diatas, disimpulkan bahwa tindakan siklus ke-2 sudah memenuhi kriteria keberhasilan yang telah ditetapkan dengan kemampuan berpikir kreatifnya termasuk kategori baik, sehingga mengalami peningkatan dari kategori "cukup baik" pada tindakan siklus ke-1 menjadi kategori "baik" pada tindakan siklus ke-2. 
Vol 2 No 2 Desember 2021

Jurnal AlphaEuclidEdu

Received: 25/10/2021; Resived: 11/11/2021; Accepted: 27/12/2021

\subsection{Pembahasan}

Pembelajaran yang dilakukan sebanyak empat kali pertemuan yaitu sebanyak dua kali pertemuan untuk pelaksanaan tindakan pada sikluske-1 dan dua kali pertemuan untuk pelaksanaan tindakan pada siklus ke-2. Pembelajaran yang dilakukan bertujuan untuk meningkatkan kemampuan berpikir kreatif siswa pada materi tabung dan kerucut. Pembelajaran yang dilakukan melalui penerapan pembelajaran Problem Posing setting kooperatif. Melalui penerapan pembelajaran penerapan pembelajaran Problem Posing setting kooperatif kemampuan berpikir kreatif siswa dalam penelitian ini meningkat. Hal ini sejalan dengan hasil penelitian lain seperti Siswono (2005) yang mengungkapkan bahwa problem posing dapat meningkatkan berpikir kreatif siswa dan Silver (1997) yang mengungkapkan bahwa kegiatan pengajuan masalah (problem posing) dapat mengembangkan kreativitas siswa.

Penerapan pembelajaran Problem Posing setting kooperatif yang dapat meningkatkan kemampuan berpikir kreatif siswa, penjelasan pelaksanaan terhadap fasefase dalam pembelajaran Problem Posing setting kooperatif sebagai berikut: 1) Fase penyampaian materi, pada fase ini peneliti menyampaikan tujuan pembelajaran dan memotivasi siswa dengan menjelaskan manfaat belajar tabung dan kerucut dalam kehidupan sehari-hari. Tujuan pembelajaran merupakan bagian proses pembelajaran yang harus dilakukan agar siswa mengetahui arah yang akan dicapai dalam pembelajaran. Sanjaya (2013: 64) menyatakan bahwa tujuan pembelajaran dapat digunakan sebagai pedoman dan panduan kegiatan belajar siswa. Setelah menyampaikan tujuan pembelajaran dan memotivasi siswa, peneliti melakukan tanya jawab untuk mengeksplorasi pengetahuan awal siswa tentang materi yang telah dipelajari sebelumnya sebagai materi prasyarat. Kemudian guru menyampaikan materi pelajaran dengan cara menjelaskan materi pelajaran dengan menggunakan media tayang slide dan tanya jawab. Setelah menyampaikan materi, peneliti meberikan contoh cara mengajukan masalah sekaligus selesaiannya berdasarkan informasi; 2) Fase pembentukan kelompok, pada fase ini peneliti mengorganisasikan siswa kedalam kelompok-kelompok belajar yang jumlah anggotanya 4 sampai 5 siswa. Kelompok yang dibentuk sifatnya heterogen berdasarkan tingkat kemapuan dan jenis kelamin. Hal ini sesuai dengan ciri-ciri pembelajaran kooperatif yang diungkapkan oleh Subanji (2013:160) yang menyatakan bahwa kelompok dibentuk secara hetergogen, berkemampuan tinggi, sedang, dan rendah. Kelompok diupayakan terdiri dari ras, budaya, suku, dan jenis kelamin yang berbeda. Pembentukan kelompok yang bersifat heterogen dalam pembelajaran problem posing setting kooperatif bertujuan untuk memberikan kesempatan kepada siswa untuk belajar secara bersama-sama dalam memahami materi pelajaran. Zakaria \& Iksan (2006) menyatakan bahwa pembelajaran kooperatif menciptakan banyak kesempatan belajar yang tidak biasanya terjadi di kelas tradisional; 3) Fase mengajukan masalah, pada fase ini siswa diminta untuk saling bekerjasama dalam mengajukan masalah dan membantu kelompok-kelompok yang mengalami kesulitan dalam mengajukan masalah. Aktivitas 
Vol 2 No 2 Desember 2021

Jurnal AlphaEuclidEdu

Received: 25/10/2021; Resived: 11/11/2021; Accepted: 27/12/2021

pengajuan masalah yang dilakukan siswa dengan cara membuat soal dapat mengarahkan siswa untuk berpikir kreatif, hal ini sesuai dengan pendapat Siswono (2005) yang menyatakan bahwa pengajuan masalah merupakan tugas kegiatan yang mengarah pada sikap kritis dan kreatif. Pada kegiatan pengajuan masalah, siswa disediakan LKPD yang memuat beberapa gambar tabung dan kerucut sebagai informasi untuk membuat soal; 4) Fase bertukar masalah, pada fase ini siswa diminta untuk saling bertukar masalah. kemudian siswa saling menyelesaikan masalah yang sudah diajukan oleh kelompok lain. Setelah selesai menyelesaikan pekerjaan kelompok, kemudian setiap kelompok untuk mengembalikan LKPD pada kelompok asal. Kelompok asal diminta untuk mengoreksi hasil pekerjaan yang telah dibuat kelompok lain. Pada saat menyelesaikan soal atau masalah dari kelompok lain, siswa ditekankan untuk saling membantu dan saling bekerja sama dengan anggota di kelompoknya. Subanji (2013:159) menyatakan bahwa setiap individu bertanggung jawab terhadap segala sesuatu di kelompoknya. Siswa yang berkemampuan tinggi diharapkan dapat membantu temannya yang mengalami kesulitan; 5) Fase presentasi kelompok, pada fase ini siswa diminta untuk mempresentasikan hasil pekerjaan kelompoknya dan jawaban dari kelompok lain. Siswa yang lain diberikan kesempatan untuk menenggapi dan bertanya. Guru sebagai fasilitaor memberikan penjelasan apabila terjadi kesalahan; 6) Fase mengevaluasi, pada fase ini siswa diberikan soal untuk mengetahui ketercapaian tujuan pembelajar yang telah ditetapkan pada awal pembelajaran. Evaluasi sangat penting dilakukan untuk melihat keberhasilan siswa dalam mencapai tujuan pembelajaran yang telah dilaksanakan. Sanjaya (2013:32) menyatakan bahwa eavluasi sebagai kegiatan yang bertujuan untuk menilai keberhasilan siswa.

\section{Kesimpulan}

Berdasarkan paparan data hasil penelitian, hasil analisis data dan pembahasan dapat disimpulkan bahwa langkah-langkah pembelajaran problem posing setting kooperatif pada materi tabung dan kerucut yang dapat meningkatkan kemampuan berpikir kreatif siswa adalah sebagai berikut : 1) menyampaikan tujuan pembelajaran, memotivasi siswa, mengeksplorasi kemampuan awal siswa, menyampaikan materi pelajaran, dan memberikan contoh membuat soal sekaligus selesaianya dengan media tayang slide, 2) mengorganisasikan siswa kedalam kelompok-kelompok belajar yang bersifat heterogen berdasarkan kemampuan dan jenis kelamin yang beranggotakan 4 sampai 5 siswa, 3) meminta siswa untuk mengajukan soal sebanyak mungkin berdasarkan informasi gambar tabung dan kerucut yang disajikan dalam LKPD, 4) meminta siswa untuk saling bertukar soal sekaligus menyelesaikan soal yang telah dibuat oleh kelompok lain, kemudian siswa diminta untuk mengembalikan soal tersebut pada kelompok asal untuk di koreksi, 5) meminta siswa untuk mempresentasikan hasil kerja kelompoknya, 6) meminta siswa untuk membuat soal sebanyak-banyaknya sekaligus selesaiannya berdasarkan informasi gambar tabung dan kerucut secara individu.

Kemampuan berpikir kreatif siswa setelah penerapan pembelajaran problem posing setting kooperatif pada penelitian ini meningkat dari kategori "cukup baik" 
Vol 2 No 2 Desember 2021

Jurnal AlphaEuclidEdu

Received: 25/10/2021; Resived: 11/11/2021; Accepted: 27/12/2021

menjadi kategori "baik". Skor kemampuan berpikir kreatif siswa dalam pembelajaran problem posing setting kooperatif pada siklus ke-1 sebesar 43 dan pada siklus ke-2 sebesar 65. Ini berarti terjadi peningkatan skor kemampuan berpikir siswa dari siklus ke1 ke siklus ke-2 sebesar 22 .

\section{Referensi}

Arikunto, S. dkk. 2014. Penelitian Tindakan Kelas. Jakarta : PT. Bumi Aksara.

Azhari \& Somakim, 2013. Peningkatan Kemampuan Berpikir Kreatif Matematika Siswa Melalui Pendekatan Konstruktivisme di Kelas VII Sekolah Menengah Pertama (SMP) Negeri 2 Banyuasin III. JurnalPendidikan Matematika Volume 7 No. 2 Juli 2013.

Bahar, A.K. \& Maker, C.J. 2011. Exploring the Relationship between Mathematical Creativity and Mathematical Achievement. Asia-Pacific Journal of Gifted and Talented Education, Volume 3, Issue 1, 2011

Christou, C. dkk. 2005. An Empirical Taxonomy of Problem Posing Processes. ZDM 2005 Vol. 37 (3).

Huda, M. 2011. Cooperative Learning. Yogyakarta: Pustaka Belajar.

Isjoni. 2013. Pembelajaran Kooperatif. Yogyakarta: Pustaka Belajar.

Kar dkk, 2010. The relation between the problem posing and problem solving skills of prospective elementary mathematics teachers. Procedia Social and Behavioral Sciences 2 (2010) 1577-1583.

Lin, P. 2004. Supporting Teachers On Desingning Problem-Posing Tasks As A Tool Of Assessment To Understand. Proceedings of the 28th Conference of the International Group for the Psychology of Mathematics Education.

Permana, A.S. 2010. Problem Posing Dalam Pembelajaran Matematika. (online), (http://achmadblue.blogspot.com/2011/05/problem-posing-dalampembelajaran.html).

Silver, E.A. \& Cai, J. (1996). An analysis of Aritmatic Problem Posing by Midlle School Students. Journal for Research In Mathematics Education, Vol. 27, No. 5 (Nov., 1996), pp. 521-539.

Silver, E.A. 1997. Fostering Creativity through Instruction Rich in Mathematical Problem Solving and Problem Posing. Zentralblatt fur Didaktik der Mathematik (ZDM) The International Journal on Mathematics Education. (online), (www.emis.de/journals/ZDM/zdm973a3.pdf).

Siswono, T. 2004. Identifikasi Proses Berpikir Kreatif Siswa dalam Pengajuan Masalah (Problem Posing) Matematika Berpandu dengan Model Wallas dan Creative Problem Solving (CPS). Buletin Pendidikan Matematika Volume 6 Nomor 2, Oktober 2004.

Siswono, T. 2005. Upaya Meningkatkan Kemampuan Berpikir Kreatif Siswa Melalui Pengajuan Masalah. Jurnal Pendidikan Matematika dan Sains", FMIPA Universitas Negeri Yogyakarta. Tahun X, No. 1, Juni 2005. (online), (https://tatagyes.files.wordpress.com/2009/.../paper05_problemposing.pdf).

Slavin R.E, 2008. Cooperative Learning. Bandung : Nusa Media. 
Vol 2 No 2 Desember 2021

Jurnal AlphaEuclidEdu

Received: 05/12/2020; Resived: 21/09/2021; Accepted: 27/12/2021

\title{
MENGATASI HAMBATAN BELAJAR DALAM MATERI PLSV MENGGUNAKAN DESAIN DIDAKTIS DENGAN SCAFFOLDING
}

\author{
${ }^{1}$ Ari Ariansyah, ${ }^{2}$ Sugiatno, ${ }^{3}$ Bistari \\ 1,2,3Pendidikan Matematika FKIP Universitas Tanjungpura Pontianak \\ Email: ariansyah06091997@gmail.com
}

\begin{abstract}
This research aimed to determine how to overcome student learning barriers in the material of onevariable linear equations using didactical design with scaffolding in class VIII of SMP Negeri 4 Sungai Raya. The form of research used in this study was didactical design research. The data source of this study were students of class VIII B of SMP Negeri 4 Sungai Raya and the data were the initial and final test answer sheets and the results of interviews. The results showed that didactic design with scaffolding can overcome student learning barriers. Before being given a didactical design with scaffolding students were not able to made mathematical models in the form of story problems, students were not able to equivalent and classify similar terms, the incompatibility of the problem solving steps ordered by the completion steps done by students, students cannot solve the problem comes to the simplest form, and students made mistakes in calculating the value of a count operation. After being given a didactical design with scaffolding students have been able to make mathematical models in the form of story questions, students have been able to equivalent and classify similar terms, the problem solving steps ordered with the completion steps done by students are appropriate, students can already solve the problem to the simplest form, and students are able to calculate the value of a calculated operation correctly even though there are a few operating errors in some problems.
\end{abstract}

Keywords: Didactical Design, Learning Obstacles, Scaffolding

\section{Pendahuluan}

Permasalahan dalam belajar matematika sering kali terjadi pada setiap siswa, bukan hanya siswa yang lambat saja, tetapi juga terjadi pada siswa yang cerdas. Permasalahan belajar tersebut terjadi cenderung berulang. Menurut pandangan beberapa ahli, permasalahan belajar itu dinamakan mereka hambatan, kesulitan, dan kesalahan belajar (Brousseo, 2002; Suryadi, 2010; Moru, 2006).

Hambatan mengandung banyak arti dalam setiap melaksanakan suatu tugas atau dalam suatu masalah tertentu. Moru (2006) menyatakan bahwa hambatan adalah sesuatu yang menghalangi pembelajaran siswa. Hambatan yang sering dihadapi oleh siswa pada umumnya dikenal dengan hambatan belajar. terjadinya hambatan belajar sesuai dengan pendapat yang telah disampaikan oleh Brousseo (2002: 86) disebabkan oleh beberapa faktor diantaranya: (1) hambatan ontogeni adalah hambatan yang berkaitan dengan kesiapan mental siswa dalam pembelajaran; (2) hambatan didaktis adalah hambatan yang berkaitan dengan bahan ajar atau cara guru mengajar yang diterapkan di dalam kelas pada saat proses pembelajaran berlangsung; dan (3) hambatan epistemologi adalah hambatan yang berkaitan dengan keterbatasan pengetahuan yang dimiliki siswa sehingga pengetahuan yang dimiliki sebelumnya tidak dapat digunakan secara utuh. Brousseau (1997: 86) mengemukakan bahwa hambatan epistemologis adalah hambatan yang terjadi akibat keterbatasan siswa pada konteks tertentu, ketika siswa dihadapkan 
dengan konteks baru siswa tampak kebingungan. Secara hirarkis hambatan belajar dapat menyebabkan siswa mengalami kesulitan belajar (Saputro et al., 2015); (Ernawati et al., 2017).

Menurut Irham (2017: 254) sebuah permasalahan yang mengakibatkan siswa belum mampu mengikuti proses pembelajaran secara baik seperti siswa lain pada umumnya yang disebabkan oleh faktor-faktor tertentu sehingga siswa tersebut terlambat atau bahkan tidak dapat mengikuti pembelajaran dengan baik sesuai dengan yang diharapkan dinamakan sebagai kesulitan belajar. Dengan demikian, adanya kesulitan serta hambatan dalam pembelajaran yang dialami siswa akan berdampak pada menurunnya prestasi belajar. Satu diantara materi yang menyebabkan siswa terhambat dan dianggap sulit bagi siswa adalah materi persamaan linear satu variabel (PLSV) (Rasmania et al., 2018).

Berdasarkan kurikulum 2013, PLSV merupakan satu diantara materi yang diajarkan di SMP. PLSV penting dipelajari siswa karena materi ini banyak kaitannya dengan materi selanjutnya, diantaranya pertidaksamaan linear satu variabel, Sistem persamaan linear dua varibel, dll . Materi PLSV banyak penerapannya dalam kehidupan sehari-hari misalnya untuk membagi waktu dalam menyelesaikan suatu pekerjaan, menentukan banyaknya uang untuk membeli sejumlah barang, dan dapat memnentukan umur seseorang. Mengingat pentingnya materi PLSV tersebut, diharapkan siswa mampu menguasai materi dengan benar. Namun kenyataan di lapangan masih banyak siswa kebingungan dalam menyelesaikan soal terkait PLSV yang disebabkan karena siswa masih merasa kesulitan dalam menyelesaikan soal tersebut. Kesulitan belajar mengakibatkan siswa sering kali melakukan kesalahan. Sejalan dengan itu Febrianti (2014: 25 ); (Saputro et al., 2015), melakukan penelitian dengan judul Identifikasi Kesalahan Siswa Kelas VII SMP Muhammadiyah Terpadu Kota Bengkulu Dalam Menyelesaikan Soal-Soal Persamaan Dan Pertidaksamaan Linier Satu Variabel yang menyatakan bahwa kesalahan-kesalahan yang dilakukan siswa pada saat mengerjakan soal terkait PLSV meliputi: kesalahan konsep, kesalahan prosedur, kesalahan operasi hitung dan tidak memberikan jawaban. Adapun faktor penyebabnya antara lain: (1) ketidaktelitian siswa dalam membaca soal; (2) siswa masih kebingungan dalam membedakan antara koefesien, variabel, dan konstanta; (3) siswa masih belum mampu memahami maksud dari soal yang diberikan sehingga belum mengerti cara mengekuivalenkan kedua ruas; (4) siswa kurang paham cara mengubah soal bentuk cerita menjadi model matematika.

Hasil penelitian tersebut sejalan berdasarkan pengalaman peneliti pada saat praktek pengalaman lapangan (PPL) di SMPN 4 Sungai Raya tahun pelajaran 2018/2019 yang mana fakta lapangan membuktikan bahwa faktor penyebab siswa mengalami kesulitan diantaranya (1) siswa kebingungan dalam memahami soal yang diberikan; (2) kesulitan dalam membuat model matematika pada soal cerita; (3) siswa kebingungan membedakan anatara koefesien, variabel, dan konstanta (4) siswa kesulitan ketika mengekuivalenkan kedua ruas dan kesulitan mengoperasikan. Berdasarkan kesalahan yang dilakukan siswa dan ketiga faktor dalam hambatan belajar terlihat bahwa 
hambatan yang dialami siswa di SMPN 4 Sungai Raya adalah hambatan yang berkaitan dengan aspek hambatan epistemologis. Berdasarkan riset terdahulu tentang permasalahan hambatan belajar yang dihadapi siswa dan sampai saat ini belum ditemukan bagaimana cara mengatasinya terkhusus pada materi PLSV, oleh sebab itu pada penelitian ini akan dibahas cara mengatasi hambatan belajar siswa.

Dari hambatan belajar yang dipaparkan sebelumnya, perlu suatu cara yang diberikan untuk mengatasi hambatan tersebut . Satu diantaranya menggunakan desain didaktis dengan scaffolding. Nur'aeni,Dkk (2016) menyatakan bahwa Desain didaktis adalah bentuk rencana pembelajaran dari bahan ajar yang berfungsi untuk mengurangi atau menghilangkan hambatan dalam belajar. Penelitian mengenai desain didaktis untuk mengatasi hambatan epistemologis telah banyak dilakukan peneliti sebelumnya, diantaranya: Hanafi (2015) yang melakukan penelitian tentang desain didaktis pembelajaran matematika untuk mengatasi hambatan epistimologis pada konsep limit fungsi aljabar. Hasil penelitian tersebut menunjukan perubahan, artinya setelah dilakukan perlakuan desain didaktis terlihat bahwa hambatan epistemologis yang teridentifikasi sebelumnya tidak muncul lagi. Madona (2013) juga melakukan penelitian mengenai desain didaktis konsep limit fungsi aljabar pada pembelajaran matematika SMA. Hasil penelitian juga menunjukan bahwa desain didaktis yang disusun cukup efektif dan berhasil dalam mengatasi kesulitan siswa saat memahami konsep tersebut.

Berdasarkan paparan tersebut, peneliti tertarik untuk mengatasi hambatan belajar yang terjadi pada siswa terkhusus dalam materi PLSV . Oleh karena itu peneliti ingin mengangkat judul untuk dijadikan penelitian yaitu "Mengatasi Hambatan Belajar Siswa Dalam Materi Persamaan Linear Satu Variabel Menggunakan Desain Didaktis dengan Scaffolding di Sekolah Menengah Pertama (SMP)”

Tujuan umum penelitian ini adalah untuk mengetahui Bagaimana Mengatasi/ Meminimalisir Hambatan Belajar Siswa Dalam Materi PLSV Menggunakan Desain Didaktis dengan Scaffolding Di Kelas VIII SMPN 4 Sungai Raya . Adapun secara khusus tujuan dalam penelitian ini adalah sebagai berikut: (1) Mengungkap hambatan epistemologis siswa sebelum diberikan pendekatan desain didaktis dengan scaffolding dalam materi persamaan linear satu variabel; (2) Mendeskripsikan rancangan pendekatan desain didaktis dengan scaffolding dalam materi persamaan linear satu variabel; (3) Mengeksplanasi perubahan hambatan epistemologis siswa setelah diberikan pendekatan desain didaktis dengan scaffolding dalam materi persamaan linear satu variabel; (4) Memperjelas eksplanasi pendekatan desain didaktis dengan scaffolding untuk mengatasi hambatan epistemologis siswa dalam materi PLSV.

\section{Metode Penelitian}

Bentuk penelitian yang digunakan dalam penelitian ini adalah menggunakan Didactical Design Research. Menurut Suryadi (2010) Didactical Design Research adalah penelitian yang terdiri dari tiga tahapan diantaranya: (a) Analisis situasi didaktis sebelum pembelajaran dimulai yang berupa dugaan kemungkinan kesulitan belajar siswa/ respon yang diberikan siswa, (b) Analisis Metapedadidaktik, serta (c) Analisis 
Retrosfektif yaitu analisis yang mengaitkan hasil analisis situasi didaktis hipotesis dengan hasil analisis metapedadidaktik.

Teknik purposive sampling digunakan untuk pemilihan siswa yang dijadikam sebagai subjek penelitian. Menurut American Journal of Theoretical and Applied Statistics (2016) purposive sampling juga disebut judgment sampling yaitu salah satu teknik non random yang melakukannya tidak perlu teori khusus yang mendasarinya tetapi pemilihan subjek yang dilakukan secara sengaja karena kebutuhan dalam penelitian. Subjek dalam penelitian ini adalah 6 siswa kelas VIIIB SMPN 4 Sungai Raya.

Objek dalam penelitian adalah suatu yang akan diselidiki selama kegiatan penelitian (Fitrah dan Luthfiansyah, 2017: 156). Berdasarkan tujuan yang sudah dikemukakan, maka objek dalam penelitian ini adalah learning obstacle (hambatan epistemologi) dalam materi persamaan linear satu variabel.

Alat pengumpulan data yang digunakan dalam penelitian ini adalah berupa tes dan wawancara. Tes adalah serangkaian pertanyaan atau sejenisnya yang digunakan peneliti untuk mengukur keterampilan, pengetahuan, intelegensi, kemampuan, atau bakat yang dimiliki oleh individu atau kelompok. Tes dalam penelitian ini terdiri dari tes awal dan tes akhir (Mahmud, 2011: 185). Pada tes awal, tes tersebut digunakan untuk mengungkap hambatan belajar khususnya hambatan epistemologis terkait dengan materi PLSV. Sedangkan tes akhir digunakan untuk mengetahui apakah hambatan belajar terkhusus hambatan epistemologis dalam materi PLSV masih muncul kembali atau tidak setelah dilakukan implementasi desain didaktis dengan scaffolding.

Wawancara adalah interaksi berupa tanya jawab yang dilakukan oleh dua pihak, yaitu si pewawancara yang memberikan pertanyaan untuk menggali informasi yang dibutuhkan dan yang diwawancarai untuk memberikan jawaban atas pertanyaan yang telah diberikan (Moleong, 2016: 186). Dalam penelitian kualitatif wawancara terdiri dari wawancara terstruktur dan wawancara tidak terstruktur. Adapun wawancara yang digunakan dalam penelitian ini adalah wawancara tidak terstruktur.

Dalam penelitian ini, wawancara dilakukan kepada 6 siswa yang dianggap paling banyak mengalami learning obstacle berdasarkan hasil tes awal. Adapun tujuan dari wawancara dalam penelitian ini adalah untuk mengetahui hambatan belajar yang dialami oleh siswa dalam mengerjakan soal yang diberikan terkait persamaan linear satu variabel. Sehingga akan memungkinkan peneliti mengetahui gambaran mengenai learning obstacle yang dihadapi serta mempermudah peneliti pada saat membuat desain didaktis.

Menurut Barbara (2014) analisis data adalah proses mengurangi sejumlah besar data yang telah dikumpulkan agar masuk akal. Teknik analisis data adalah suatu teknik analisis yang digunakan untuk menjawab rumusan masalah atau menguji hipotesis yang telah dirumuskan dalam proposal (Sugiyono, 2016: 333). Teknik analisis data yang dilakukan pada penelitian ini terfokus pada jawaban tes awal dan tes akhir siswa dan respon atau jawaban siswa ketika di wawancarai. 


\section{Hasil Penelitian dan Pembahasan}

\subsection{Hasil Penelitian}

Hasil Tabel 1. Hasil Penelitian Hambatan pada Tes Awal dan Tes Akhir

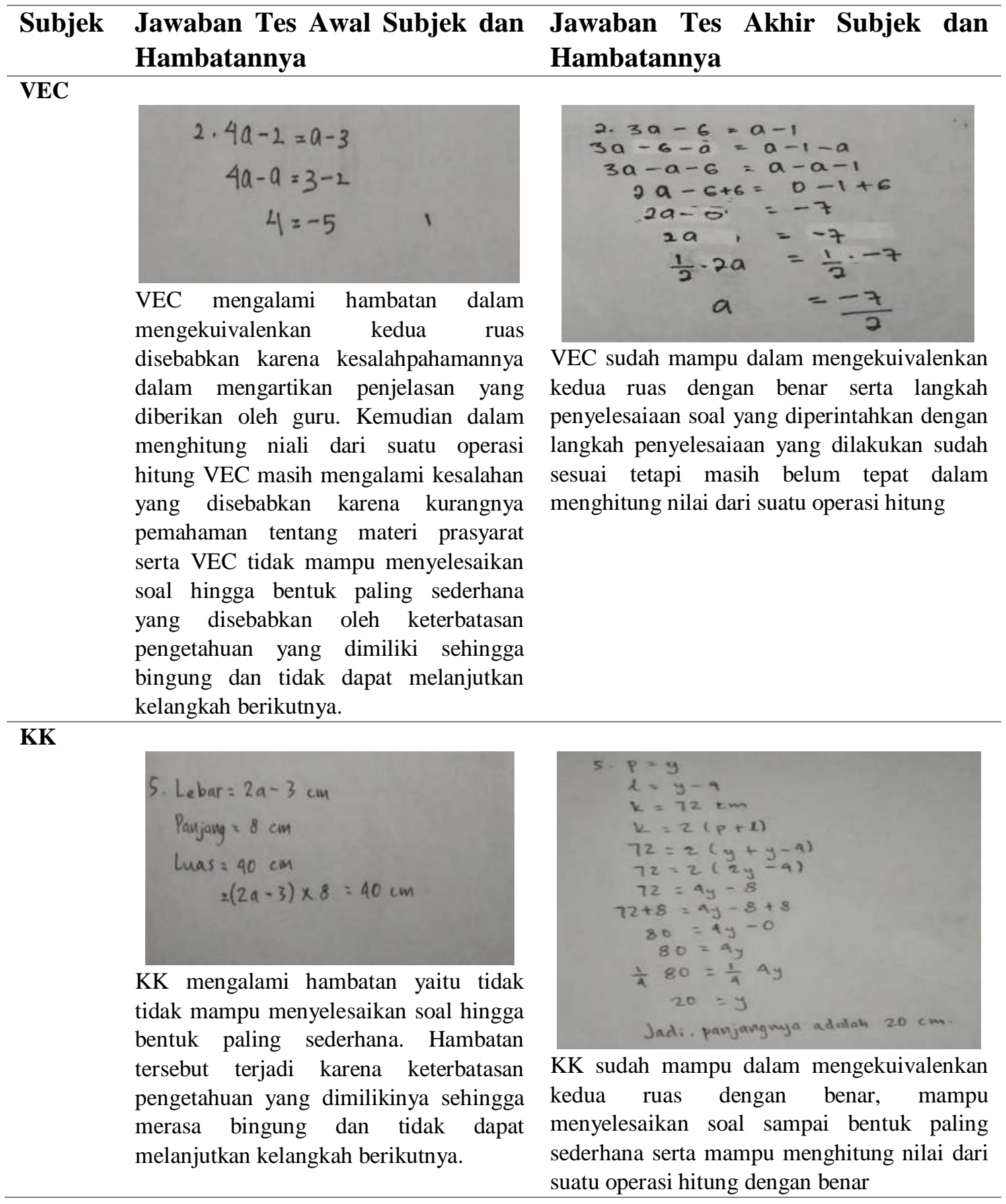


M mengalami hambatan dalammembuat model matematika, mengekuivalenkan kedua ruas, langkah penyelesaiaan soal yang diperintahkan dengan langkah penyelesaiaan yang dilakukannya tidak sesuai serta mengalami hambatan dalam mengoperasikan. Hambatan tersebut terjadi karena keterbatasan pengetahuan yang dimiliki subjek yang disebabkan karean ketidakmampuannya mengingat materi sebelumnya (lupa).

JA

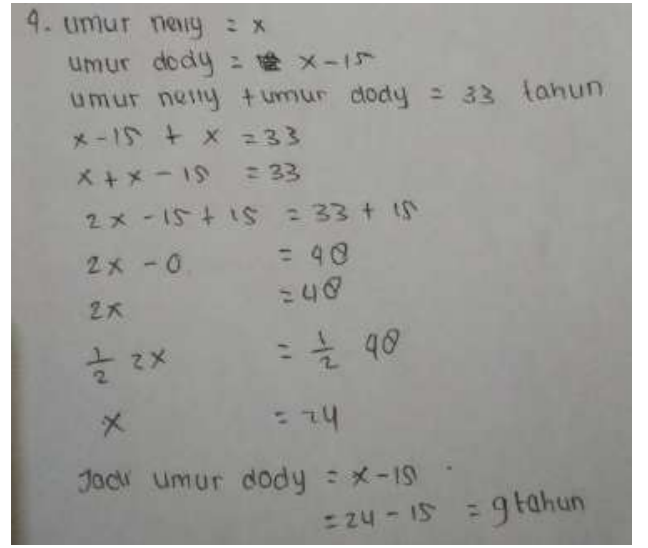

M sudah mampu dalam mengekuivalenkan kedua ruas dengan benar, langkah penyelesaiaan soal yang diperintahkan dengan langkah penyelesaiaan yang dilakukan sudah sesuai serta mampu menghitung nilai dari suatu operasi hitung dengan benar

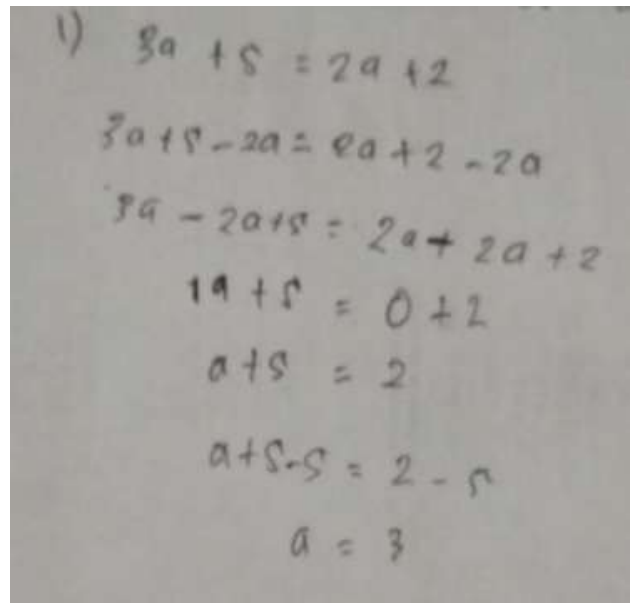

JA sudah mampu dalam mengekuivalenkan kedua ruas dan dapat menyelesaikan soal sampai bentuk paling sederhana tetapi masih melakukan kesalahan menghitung nilai dari suatu operasi hitung. 


\begin{tabular}{|c|c|c|}
\hline \multicolumn{3}{|l|}{ WW } \\
\hline & 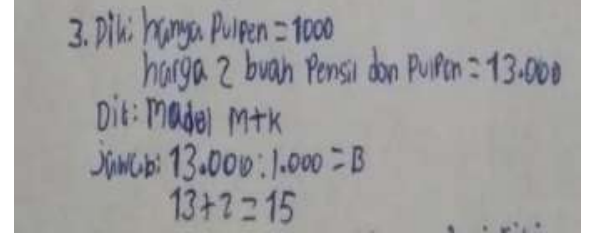 & 3. $\begin{array}{rl}P=\cdots ? & \\
k=60 & k=2(P+L) \\
k=60=2(x+x-6) & \\
& 60=2(2 x-6) \\
& 60=4 x-12\end{array}$ \\
\hline & $\begin{array}{l}\text { WW mengalami hambatan membuat } \\
\text { model matematika dalam bentuk soal } \\
\text { cerita disebabkan karena malu untuk } \\
\text { bertanya }\end{array}$ & $\begin{array}{l}\text { WW sudah mampu membuat model } \\
\text { matematika dalam bentuk soal cerita dengan } \\
\text { benar dan langkah penyelesaiaan soal yang } \\
\text { diperintahkan dengan langkah penyelesaian } \\
\text { yang dilakukan sudah sesuai serta mampu } \\
\text { menghitung nilai dari suatu operasi hitung } \\
\text { dengan benar }\end{array}$ \\
\hline \multicolumn{3}{|l|}{ FT } \\
\hline & $\begin{aligned} 1.2 a+2 & =a+3 \\
2 a+3 z & =3+2 \\
A & =5\end{aligned}$ & \multirow{2}{*}{$\begin{array}{l}\text { 1. } 3 a+5=2 a+2 \\
3 a+5-2 a=2 a+2-2 a \\
3 a-2 a+5=2 a-2 a+2 \\
a+5=0+2 \\
a+5=2 \\
a+5-5=2-5 \\
a+0=-3 \\
a=-3\end{array}$} \\
\hline & \multirow{2}{*}{$\begin{array}{l}\text { FT mengalami hambatan dalam } \\
\text { mengekuivalenkan kedua ruas diebabkan } \\
\text { karena ketidakmampuan siswa } \\
\text { memahami materi jika hanya dengan satu } \\
\text { atau dua kali penjelasan yang diberikan } \\
\text { guru serta FT belum mampu mengitung } \\
\text { nilai dari opeasi hitung dengan benar } \\
\text { disebabkan karena kurangnya }\end{array}$} & \\
\hline & & $\begin{array}{l}\text { FT sudah mampu dalam mengekuivalenkan } \\
\text { kedua ruas dan mampu menghitung nilai dari } \\
\text { suatu operasi hitung dengan benar, serta dapat } \\
\text { menyelesaikan soal sampai bentuk paling } \\
\text { sederhana }\end{array}$ \\
\hline & $\begin{array}{l}\text { pemahaman siswa tentang materi } \\
\text { prasyarat }\end{array}$ & \\
\hline
\end{tabular}

Berdasarkan tes awal, keenam subjek dalam materi PLSV masih mengalami hambatan, baik itu terkait konseptual, prosedural, maupun teknik operasional. Hambatan konseptual yang dialami subjek yaitu: (1) Subjek tidak mampu membuat model matematika dalam bentuk soal cerita; (2) Subjek tidak mampu dalam mengekuivalenkan dan mengelompokkan suku-suku yang sejenis (sama). Hambatan prosedural yang dialami subjek yaitu: (1) Ketidaksesuaian langkah penyelesaiaan soal yang diperintahkan dengan langkah penyelesaiaan yang dilakukan siswa; (2) Subjek tidak dapat menyelesaikan soal sampai pada bentuk paling sederhana. Hambatan teknik operasional yang dialami subjek yaitu: (1) Subjek melakukan kesalahan dalam menghitung niali dari suatu operasi hitung.

\subsection{Pembahasan}

Pada tahap pertama peneliti memberikan tes awal bertujuan untuk mengungkap hambatan yang terjadi pada siswa. Setelah ditemukannya hambatan tersebut selanjutnya peneliti merancang desain didaktis dengan scaffolding sesuai dengan hambatan yang diialami siswa bertujuan agar hambatan tersebut tidak terjadi lagi atau 
terminimalisir. Tahap kedua, peneliti memberikan implementasi desain didaktis dengan scaffolding yang sudah dibuat kepada 6 orang subjek yang bertujuan untuk mengatasi learning obstacle (hambatan epistemologi) dalam materi persamaan linear satu variabel.

Pada saat implementasi desain didaktis dengan scaffolding diberikan kepada 6 subjek secara bersamaan, scaffolding yang diberikan pada saat pembelajaran yaitu: (1) Mengingatkan subjek mengenai koefesien, variabel dan konstanta; (2) Mengingatkan subjek mengenai suku-suku yang sejenis; (3) Menjelaskan cara mengekuivalenkan kedua ruas dan mengelompokkan suku yang sejenis dengan benar; (4) Mengingatkan kembali tentang materi opersai bilangan bulat dan operasi bentuk aljabar; (5) Menjelaskan cara mengoperasikan dengan benar; (6) Membimbing siswa membuat model matematika dalm bentuk soal cerita; (7) Membimbing siswa langkah demi langkah hingga pada langkah terakhir. Selain itu juga peneliti memberikan scaffolding secara individu kepada subjek yang masih mengalami hambatan dengan cara menanyakan kembali bagian yang belum mereka pahami dan mejelaskan secara runtut.

Hambatan konseptual yang dialami VEC yaitu tidak mampu dalam mengekuivalenkan kedua ruas, tidak mampu dalam mengelompokkan suku-suku yang sejenis (sama), tidak mampu membuat model matematika dalam bentuk soal cerita. Hambatan konseptual tersebut terjadi karena disebabkan oleh beberapa faktor. Berdasarkan hasil wawancara peneliti dengan subjek VEC faktor penyebeb VEC salah dalam mengekuivalenkan kedua ruas dan salah dalam mengelompokkan suku sejenis, peneliti menyimpulkan bahwa terjadi kesalahpahaman subjek dalam mengartikan penjelasan yang diberikan oleh guru. kemudian berdasarkan hasil wawancara juga penyebab subjek VEC salah dalam membuat model matematika adalah ketidakmampuannya mengingat materi sebelumnya (lupa). Dengan scaffolding peneliti meluruskan kesalahpahaman tersebut dengan cara membimbing dan menjelaskan cara mengekuivalenkan dan mengelompokkan suku sejenis serta mengingatkan dan membimbing subjek membuat model matematika dengan benar. Ternyata setelah implementasi kesalahpahaman subjek VEC sudah dapat teratasi dan sudah dapat mengingat materi sebelumnya sehingga subjek sudah mampu dalam menekuivalenkaan kedua ruas, mengelompokkan suku sejens serta membuat model matematika.

Hambatan prosedural yang dialami VEC adalah ketidakmampuanya dalam menyelesaikan soal sampai bentuk paling sederhana. Berdasarkan hasil wawancara peneliti dengan subjek hambatan tersebut disebabkan oleh keterbatasan pengetahuan yang dimiliki sehingga merasa bingung dan tidak dapat melanjutkan kelangkah berikutnya. Dengan scaffolding peneliti menjelaskan cara menyelesaikan soal secara sistematis hingga bentuk paling sederhana. Ternyata setelah implementasi subjek tidak merasa bingung lagi dan sudah dapat menyelesaikan soal sampai bentuk paling sederhana.

Hambatan teknik operasional yang dialami VEC adalah melakukan kesalahan dalam menghitung niali dari suatu operasi hitung. Berdasarkan hasil wawancara peneliti dengan subjek hambatan tersebut disebabkan karena kurangnya pemahaman tentang materi prasyarat. Dengan scaffolding peneliti mengingatkan kembali operasi 
bentuk aljabar dan menjelaskan cara menghitung nilai dari suatu operasi hitung dengan benar. Ternyata setelah implementasi subjek VEC sudah mampu menghitung dengan benar pada soal no 2, 3, 4, dan 5. Namun masih mengalami sedikit kesalahan mengoperasikan pada soal no 1 disebabkan karena keterbatasan pengetahuan subjek terkait materi prasyarat.

Hambatan konseptual yang dialami KK yaitu tidak mampu dalam mengekuivalenkan kedua ruas, tidak mampu dalam mengelompokkan suku-suku yang sejenis (sama), tidak mampu membuat model matematika dalam bentuk soal cerita. Hambatan konseptual tersebut terjadi karena disebabkan oleh beberapa faktor. Berdasarkan hasil wawancara peneliti dengan subjek KK faktor penyebeb KK salah dalam mengekuivalenkan kedua ruas dan salah dalam mengelompokkan suku sejenis, peneliti menyimpulkan bahwa terjadi kesalahpahaman subjek dalam mengartikan penjelasan yang diberikan oleh guru. kemudian berdasarkan hasil wawancara juga penyebab subjek KK salah dalam membuat model matematika adalah subjek kurang mendengarkan penjelasan guru karena suasana kelas yang tidak kondusif. Dengan scaffolding peneliti meluruskan kesalahpahaman tersebut dengan cara membimbing dan menjelaskan cara mengekuivalenkan dan mengelompokkan suku sejenis serta membimbing subjek membuat model matematika dengan benar. Ternyata setelah implementasi kesalahpahaman subjek KK sudah dapat teratasi dan subjek sudah mampu dalam menekuivalenkaan kedua ruas, mengelompokkan suku sejens serta membuat model matematika dengan benar.

Hambatan prosedural yang dialami KK adalah ketidakmampuanya dalam menyelesaikan soal sampai bentuk paling sederhana. Berdasarkan hasil wawancara peneliti dengan subjek hambatan tersebut disebabkan oleh keterbatasan pengetahuan yang dimiliki sehingga merasa bingung dan tidak dapat melanjutkan kelangkah berikutnya. Dengan scaffolding peneliti menjelaskan cara menyelesaikan soal secara sistematis hingga bentuk paling sderhana. Ternyata setelah implementasi subjek tidak merasa bingung lagi dan sudah dapat menyelesaikan soal sampai bentuk paling sederhana.

Hambatan konseptual yang dialami $\mathrm{M}$ yaitu tidak mampu dalam mengekuivalenkan kedua ruas, tidak mampu dalam mengelompokkan suku-suku yang sejenis (sama), tidak mampu membuat model matematika dalam bentuk soal cerita. Hambatan konseptual tersebut terjadi karena disebabkan oleh beberapa faktor. Berdasarkan hasil wawancara peneliti dengan subjek $\mathrm{M}$ faktor penyebeb $\mathrm{M}$ salah dalam mengekuivalenkan kedua ruas dan salah dalam mengelompokkan suku sejenis, peneliti menyimpulkan bahwa terjadi kesalahpahaman subjek dalam mengartikan penjelasan yang diberikan oleh guru. kemudian berdasarkan hasil wawancara juga penyebab subjek $\mathrm{M}$ salah dalam membuat model matematika adalah ketidakmampuannya mengingat materi sebelumnya (lupa). Dengan scaffolding peneliti meluruskan kesalahpahaman tersebut dengan cara membimbing dan menjelaskan cara mengekuivalenkan dan mengelompokkan suku sejenis serta mengingatkan dan membimbing subjek membuat model matematika dengan benar. Ternyata setelah implementasi kesalahpahaman subjek M sudah dapat 
teratasi dan sudah dapat mengingat materi sebelumnya sehingga subjek sudah mampu dalam mengekuivalenkaan kedua ruas, mengelompokkan suku sejens serta membuat model matematika dengan benar.

Hambatan prosedural yang dialami $M$ adalah ketidakmampuanya dalam menyelesaikan soal sampai bentuk paling sederhana, langkah penyelesaiaan soal yang diperintahkan dengan langkah penyelesaiaan yang dilakukan siswa tidak sesuai. Berdasarkan hasil wawancara peneliti dengan subjek hambatan tersebut disebabkan oleh keterbatasan pengetahuan yang dimiliki sehingga merasa bingung dan tidak dapat melanjutkan kelangkah berikutnya. Dengan scaffolding peneliti menjelaskan cara menyelesaikan soal secara sistematis hingga bentuk paling sderhana. Ternyata setelah implementasi subjek tidak merasa bingung lagi dan sudah dapat menyelesaikan soal sampai bentuk paling sederhana.

Hambatan teknik operasional yang dialami $\mathrm{M}$ adalah dalam menghitung niali dari suatu operasi hitung $\mathrm{M}$ masih mengalami kesalahan. Berdasarkan hasil wawancara peneliti dengan subjek hambatan tersebut disebabkan karena kurangnya pemahaman tentang materi prasyarat. Dengan scaffolding peneliti mengingatkan kembali operasi bilangan bulat dan menjelaskan cara menghitung nilai dari suatu operasi hitung dengan benar. Ternyata setelah implementasi subjek $M$ sudah mampu menghitung nilai dari suatu operasi hitung dengan benar.

Hambatan konseptual tersebut terjadi karena disebabkan oleh beberapa faktor. Berdasarkan hasil wawancara peneliti dengan subjek JA faktor penyebeb JA salah dalam mengekuivalenkan kedua ruas dan salah dalam mengelompokkan suku sejenis karena guru yang bersangkutan terlalu cepat dalam menjelaskan materi yang berkaitan dengan PLSV. kemudian berdasarkan hasil wawancara juga penyebab subjek JA salah dalam membuat model matematika adalah ketidakmampuannya mengingat materi sebelumnya (lupa). Dengan scaffolding secara perlahan dan tidak terburu-terburu peneliti menjelaskan cara mengekuivalenkan dan mengelompokkan suku sejenis serta mengingatkan dan membimbing subjek membuat model matematika dengan benar. Ternyata setelah implementasi subjek JA sudah mampu dalam mengekuivalenkaan kedua ruas, mengelompokkan suku sejens serta membuat model matematika dengan benar.

Hambatan prosedural yang dialami JA adalah ketidakmampuanya dalam menyelesaikan soal sampai bentuk paling sederhana. Berdasarkan hasil wawancara peneliti dengan subjek hambatan tersebut disebabkan oleh keterbatasan pengetahuan yang dimiliki sehingga merasa bingung dan tidak dapat melanjutkan kelangkah berikutnya. Dengan scaffolding peneliti menjelaskan cara menyelesaikan soal secara sistematis hingga bentuk paling sderhana. Ternyata setelah implementasi subjek tidak merasa bingung lagi dan sudah dapat menyelesaikan soal sampai bentuk paling sederhana.

Hambatan teknik operasional yang dialami JA adalah dalam menghitung niali dari suatu operasi hitung JA masih mengalami kesalahan. Berdasarkan hasil wawancara peneliti dengan subjek hambatan tersebut disebabkan karena kurangnya pemahaman 
tentang materi prasyarat. Dengan scaffolding peneliti mengingatkan kembali operasi bentuk aljabar dan menjelaskan cara menghitung nilai dari suatu operasi hitung dengan benar. Ternyata setelah implementasi subjek JA sudah mampu menghitung nilai dari suatu operasi hitung dengan benar pada soal no 2,3,4. Namun masih mengalami sedikit kesalahan mengoperasikan pada soal no 1 dan no 5 disebabkan karena kekeliruan atau ketidaktelitian karena tidak mngecek ulang jawaban yang telah dituliskan

Subjek WW dalam materi persamaan linear satu variabel sebelum diberikan desain didaktis dengan scaffolding masih mengalami hambatan, baik itu hambatan konseptual, hambatn prosedural, maupun hambatan teknik operasional.

Hambatan konseptual yang dialami WW yaitu tidak mampu dalam mengekuivalenkan kedua ruas, tidak mampu dalam mengelompokkan suku-suku yang sejenis (sama), tidak mampu membuat model matematika dalam bentuk soal cerita. Hambatan konseptual tersebut terjadi karena disebabkan oleh beberapa faktor. Berdasarkan hasil wawancara peneliti dengan subjek WW faktor penyebeb WW salah dalam mengekuivalenkan kedua ruas, salah dalam mengelompokkan suku sejenis, dan salah dalam membuat model matematika dikarenakan subjek malu untuk bertanya. Dengan scaffolding peneliti membimbing dan menjelaskan cara mengekuivalenkan dan mengelompokkan suku sejenis serta membimbing subjek membuat model matematika dengan benar. Setelah itu, peneliti memberikan scaffolding secara individu kepada subjek dengan cara menghampiri dan menanyakan kepada subjek terkait yang belum ia pahami serta menjelaskannya. Selain itu juga peneliti memberikan motivasi agar subjek berani untuk bertanya jika belum memahami materi yang dijelaskan oleh guru. Ternyata setelah implementasi subjek WW sudah dapat teratasi, dan subjek sudah mampu dalam mengekuivalenkaan kedua ruas, mengelompokkan suku sejens serta membuat model matematika dengan benar.

Hambatan prosedural yang dialami WW adalah ketidakmampuanya dalam menyelesaikan soal sampai bentuk paling sederhana, ketidaksesuaiaan langkah penyelesaiaan soal yang diperintahkan dengan langkah penyelesaiaan yang dilakukan. Berdasarkan hasil wawancara peneliti dengan subjek hambatan tersebut disebabkan karena subjek tidak terbiasa membuat langkah penyelesaian secara sistematis. Dengan scaffolding peneliti menjelaskan cara menyelesaikan soal secara sistematis hingga bentuk paling sderhana. Ternyata setelah implementasi subjek dapat menyelesaikan soal sampai bentuk paling sederhana.

Hambatan teknik operasional yang dialami WW adalah dalam menghitung niali dari suatu operasi hitung WW masih mengalami kesalahan. Berdasarkan hasil wawancara peneliti dengan subjek hambatan tersebut disebabkan karena kurangnya pemahaman tentang materi prasyarat. Dengan scaffolding peneliti mengingatkan kembali operasi bentuk aljabar dan menjelaskan cara menghitung nilai dari suatu operasi hitung dengan benar. Ternyata setelah implementasi subjek WW sudah mampu menghitung nilai dari suatu operasi hitung dengan benar.

Hambatan konseptual yang dialami FT yaitu tidak mampu dalam mengekuivalenkan kedua ruas, tidak mampu dalam mengelompokkan suku-suku yang 
sejenis (sama), tidak mampu membuat model matematika dalam bentuk soal cerita. Hambatan konseptual tersebut karena disebabkan oleh beberapa faktor. Berdasarkan hasil wawancara peneliti dengan subjek FT faktor penyebeb FT salah dalam mengekuivalenkan kedua ruas, salah dalam mengelompokkan suku sejenis, dan salah dalam membuat model matematika dikarenakan ketidakmampuan FT memahami materi jika hanya dengan satu atau dua kali penjelasan yang diberikan guru. Dengan scaffolding peneliti membimbing dan menjelaskan cara mengekuivalenkan dan mengelompokkan suku sejenis serta membimbing subjek membuat model matematika dengan benar. Setelah itu, peneliti memberikan scaffolding secara individu kepada subjek dengan cara menghampiri dan menanyakan kepada subjek terkait yang belum ia pahami serta menjelaskannya. Ternyata setelah implementasi subjek FT sudah dapat teratasi, dan subjek sudah mampu dalam mengekuivalenkaan kedua ruas, mengelompokkan suku sejens serta membuat model matematika dengan benar.

Hambatan prosedural yang dialami FT adalah ketidakmampuanya dalam menyelesaikan soal sampai bentuk paling sederhana, ketidaksesuaiaan langkah penyelesaiaan soal yang diperintahkan dengan langkah penyelesaiaan yang dilakukan. Berdasarkan hasil wawancara peneliti dengan subjek hambatan tersebut disebabkan karena subjek tidak terbiasa membuat langkah penyelesaian secara sistematis. Dengan scaffolding peneliti menjelaskan cara menyelesaikan soal secara sistematis hingga bentuk paling sderhana. Ternyata setelah implementasi subjek dapat menyelesaikan soal sampai bentuk paling sederhana.

Hambatan teknik operasional yang dialami FT adalah dalam menghitung niali dari suatu operasi hitung FT masih mengalami kesalahan. Berdasarkan hasil wawancara peneliti dengan subjek hambatan tersebut disebabkan karena kurangnya pemahaman tentang materi prasyarat. Dengan scaffolding peneliti mengingatkan kembali operasi bentuk aljabar dan menjelaskan cara menghitung nilai dari suatu operasi hitung dengan benar. Ternyata setelah implementasi subjek FT sudah mampu menghitung nilai dari suatu operasi hitung dengan benar.

Dari hasil analisis 6 subjek terlihat bahwa hambatan yang dialami subjek pada tes awal berkurang bahkan tidak muncul kembali pada saat diberikan desain didaktis dengan scaffolding. Artinya, desain didaktis dengan scaffolding cukup berhasil dalam mengatasi/meminimalisir hambatan epistemologi khusunya pada materi persamaan linear satu variabel. Serta respon dari subjek juga terbilang cukup baik ketika peneliti menanyakan perlakuan yang diberikan pada saat penelitian berlangsung.

\section{Kesimpulan}

Berdasarkan hasil jawaban tes awal sebelum diberikan perlakuan menggunakan desain didaktis dengan scaffolding terlihat bahwa subjek mengalami hambatan baik itu konseptual, prosedural, maupun teknik operasional. Adapun desain didaktis dengan scaffolding yang diberikan untuk mengatasi hambatan tersebut berupa: Mengingatkan subjek mengenai koefesien, variabel dan konstanta, mengingatkan subjek mengenai suku-suku yang sejenis, menjelaskan cara mengekuivalenkan kedua ruas dan 
mengelompokkan suku yang sejenis dengan benar, mengingatkan kembali tentang materi opersai bilangan bulat dan operasi bentuk aljabar, menjelaskan cara mengoperasikan dengan benar, membimbing siswa membuat model matematika dalm bentuk soal cerita, embimbing siswa langkah demi langkah hingga pada langkah terakhir. Selain itu juga peneliti memberikan scaffolding secara individu kepada subjek yang masih mengalami hambatan dengan cara menanyakan kembali bagian yang belum mereka pahami dan mejelaskan secara runtut. Berdasarkan hasil jawaban tes akhir yang diberikan setelah implementasi desain didaktis dengan scaffolding terlihat bahwa hambatan yang muncul pada saat tes awal menjadi berkurang atau bahkan tidak muncul lagi pada saat diberikan tes akhir. Dengan demikian Desain didaktis dengan scaffolding dapat mengatasi/ meminimalisir sebagian besar hambatan yang dialami subjek

\section{Referensi}

Barbara, kawulich. (2014). Data Analysis Techniques in Qualitative Research. In Darla Twale (Ed) Jornal of Research in Education.14(1)p. 96 - 113.

Brousseau, G. (1997). Theory Of Didactical Situations In Mathematics. Dordrecht: Kluwer Academic Publishers.

Anonim. (2002). Theory Of Didactical Situations In Mathematics. Vol 19. America: Kluwer Academic Publishers.

Ernawati, Suratman, D., \& Bistari. (2017). Pengembangan desain didaktis penalaran spasial dan penalaran kuantitif dalam materi teorema pythagoras di smp. Jurnal Penelitian, $1-10$. http://jurnal.untan.ac.id/index.php/jpdpb/article/view/22867/18131

Rasmania, Sugiatno, S., \& Suratman, D. (2018). Hambatan Epistimologis Siswa Dalam Menentukan Domain Dan Range Fungsi Kuadrat Di Sekolah Menengah Atas. Jurnal Pendidikan Dan Pembelajaran Khatulistiwa, 7(7), 1-9.

Saputro, M., Yadi, A., \& Dona, F. (2015). Faktor-Faktor yang Mempengaruhi Prestasi

Belajar (Studi Korelasi Pada Mahasiswa Pendidikan Matematika IKIP PGRI Pontianak). Jurnal Pendidikan Informatika Dan Sains, 4(2), 233-246.

Sugiyono. (2016). Metode Penelitian Kuantitatif, Kualitatif Dan, R\&D. Bandung: Alfabeta.

Suryadi, Didi. (2010). Didactical Design Research (DDR) Dalam Pengembangan Pembelajaran Matematika 1, Jurnal ilmu pendidikan, (online), (http://ejurnal.fkip.upi.ac.id, diakses 17 april 2019). 
Vol 2 No 2 Desember 2021

Jurnal AlphaEuclidEdu

Received: 23/09/2021; Resived: 01/10/2021; Accepted: 27/12/2021

\title{
EKSPLORASI SIKAP MAHASISWA PENDIDIKAN MATEMATIKA DALAM PEMBELAJARAN MATEMATIKA
}

\author{
Yulis Jamiah \\ Prodi Pendidikan Matematika, FKIP Universitas Tanjungpura \\ E-mail: vulis.jamiah@fkip.untan.ac.id
}

\begin{abstract}
In essence, an appropriate and interesting learning process for students will encourage them to optimize their potential. On the other hand, if educators/lecturers carry out the process of learning activities that are less creative and less innovative, can you imagine what will happen? The students interacting in the learning process are not like empty bottles, but they have brought cultural values brought from their families and communities. Wise educators must be able to understand the diversity of their attitudes in the learning process. Exploration of student attitudes in learning mathematics can be used as a vehicle to understand student character. Attitude is a readiness to react to objects in a certain environment and as an appreciation of the object. There are three main components that together form a complete attitude, namely: a) belief in an object, b) emotional life or evaluation of an object, and c) tendency to act. Understanding of student attitudes will make it easier to interact in the learning process.
\end{abstract}

Keywords: Attitude, Mathematics Learning.

\section{Pendahuluan}

Matematika merupakan ilmu yang memegang peranan cukup penting dalam pengembangan ilmu pengetahuan dan teknologi. Oleh karena itu agar matematika dapat berperan aktif dalam kehidupan yang terus berkembang ini, maka penguasaan terhadap matematika merupakan suatu keharusan. Penguasaan terhadap matematika ini dapat menjadikan seorang untuk berpikir dan bernalar secara teratur, logis dan konsisten. Untuk menguasai matematika dapat dilakukan melalui jalur pendidikan formal maupun non formal, melalui jalur pendidikan formal inilah akan mengenal terjadinya proses kegiatan pembelajaran di kelas.Pendidikan formal ini ada 3 aspek yang merupakan sasaran dalam proses kegiatannya, yaitu aspek kognitif, aspek afektif dan aspek psikomotor. Dalam aspek afektif terdapat satu komponen yang cukup penting dan mempengaruhi belajar mahasiswa, yakni komponen sikap.

Sikap mahasiswa menyenangi matematika, maka sikapnya itu tentu mempengaruhi prilakunya terhadap matematika. Sikap yang ditunjukkan sebaliknya, tentu merupakan salah satu hambatan dalam belajar matematika untukmencapai prestasi belajar yang tinggi. Oleh karena itu seorang pendidik/dosen tidak hanya menitikberatkan pada aspek kognitif dan psikomotor tetapi aspek afektif terutamasikap. Karena dengan terbentuknya sikap yang positif terhadap matematika sangat membantu mahasiswa menguasai materi matematika dengan baik.

Penguasaan materi matematika yang baik, penyajiannya dalam pembelajaran matematika harus memahami karakteristiknya, yaitu: 1) pembelajaran matematika berjenjang (bertahap), artinya materi pembelajaran diajarkan secara berjenjang atau bertahap dari hal konkrit ke abstrak, hal yang sederhana ke kompleks, atau dari konsep mudah ke konsep yang lebih sukar; 2) pembelajaran matematika mengikuti metoda spiral, artinya setiap mempelajari konsep baru perlu memperhatikan konsep atau bahan yang telah dipelajari sebelumnya; 3) pembelajaran matematika menekankan pola pikir deduktif, yang harus dapat dipilihkan pendekatan yang cocok dengan kondisi pembelajar; dan 4) pembelajaran matematika menganut kebenaran konsistensi, artinya 
Vol 2 No 2 Desember 2021

Jurnal AlphaEuclidEdu

Received: 23/09/2021; Resived: 01/10/2021; Accepted: 27/12/2021

kebenaran-kebenaran dalam matematika pada dasarnya merupakan kebenaran konsistensi, tidak bertentangan antara kebenaran suatu konsep dengan yang lainnya (Soedjadi, 2004); Bambang, 2007).

Berdasarkan pengalaman dan hasil pengamatan penulis selama memberikan perkuliahan maupun pembimbingan tiga tahun terakhir ini, terungkap suatu indikasi bahwa profil kelulusan mahasiswa lebih dominan mementingkan hasil akhir dalam aspek pengetahuan, dan kurang memperhatikan aspek sikap. Indikasi ini diperlihatkan dengan prilaku ingin cepat atauinstan untuk memperoleh sesuatu yang diinginkannya.

Sikap mahasiswa menyenangi matematika, maka sikapnya itu tentu mempengaruhi prilakunya terhadap matematika. Sebaliknya sikap tidak menyukai matematika merupakan salah satu hambatan dalam belajar matematika. Oleh karena itu, seorang dosen untuk mewujudkankemampuan minimal yang harus dikuasai mahasiswa tidak hanya menitikberatkan padaaspek pengetahuan saja, tetapi harus menyeimbangkan aspek ketrampilan dan aspek sikap. Karena dengan terbentuknya sikap yang positif terhadap matematika, hal ini sangat membantu mahasiswa dalam menguasai materi.

Hasil pengamatan tiga tahun terakhir yang penulis lakukan, mengindikasikan hasilyang kontradiktif dengan hasil penelitian tahun 2006, yakni mendeskripsikan sikap mahasiswa semester VI Jurusan PMIPA Program Studi Pendidikan Matematikamelalui pembelajaran matematika dalammata kuliah Struktur Aljabar. Berdasarkan 34pernyataan dengan muatan tentang sikap, yang dipilih oleh 31 mahasiswa, menunjukkan hasil sebagai berikut: 1) terdapat 3,22 \% (satu mahasiswa) menyatakan sikap sangat negatip; 2) terdapat3,22\% (satu mahasiswa) menyatakan sikap negatip; 3 ) terdapat 6,34 \% (dua mahasiswa) menyatakan sikap ragu-ragu; dan 4) terdapat 54,83 \% (17 mahasiswa) menyatakan sikap positif; serta 5) terdapat 32,25 \% (10 mahasiswa) menyatakan sikap sangat positip.Hasil tersebut, sebagian besar mahasiswa $( \pm 87 \%)$ memberikan tanggapan bahwa mahasiswa dalam mempelajari matematika di semester enam, khususnya mata kuliahStruktur Aljabar bersikap positip dan sangat positip. Hal ini memberikan makna bahwa sikap mahsiswa, seperti: sangat senang, tanggung jawab, merespon dengan baik terhadap pembelajaran matematika dalam mata kuliah Struktur Aljabar.

Faktor yang mempengaruhi perolehan belajar, di antaranya adalah sikap. Menurut Azwar, (1988), Sikap sebagai derajat perasaan positif atau negatf yang dikaitkan dengan suatu objek psikologis. Sikap merupakan sesuatu yang dipelajari, dan sikap menentukan bagaimana individu bereaksi terhadap situasi serta menentukan apa yang dicari individu dalam kehidupan. Triandis (Slameto, 1991: 191) mendefinisikan sebagai berikut. An attitude is an idea charged with emation which predisposes a class of action to a particular class of social situations. Sikap mempunyai persamaan unsur, yaitu adanya kesediaan untuk berespon terhadap suatu situasi. Sikapterbentuk melalui beberapan cara, diantaranya: 1) melalui pengalaman yang berulang-ulang, 2) melalui imitasi/peniruan, 3) melalui sugesti, dan 4) melalui identifikasi(Slameto, 1991: 192).

Sikap merupakan kesiapan untuk bereaksi terhadap objek di lingkungan tertentu sebagai suatu penghayatan terhadap objek. Allport (Notoatmodjo, 2007) menjelaskan bahwa sikap itu mempunyai tigakomponen pokok yang secara bersama-samamembentuk sikap yang utuh, yakni: a) kepercayaan (keyakinan), ide dan konsep terhadap suatu objek, b) kehidupan emosional atau evaluasi terhadap suatu objek, dan c) kecenderungan untuk bertindak. Sikap yang utuh ini, pengetahuan, pikiran, keyakinan dan emosi memegang peranan penting. Selain adanya komponen pokok, sikap juga terbagai 
Vol 2 No 2 Desember 2021

Jurnal AlphaEuclidEdu

Received: 23/09/2021; Resived: 01/10/2021; Accepted: 27/12/2021

tingkatannya, yakni: i) menerima artinya subjek memperhatikan stimulus yang diberikan, ii) merespon artinya memberikan jawaban apabila ditanya, mengerjakan dan menyelesaikan tugas yang diberikan, iii) menghargai artinya mengajak orang lain untuk mengerjakan ataumendiskusikan suatu masalah, dan iv) bertanggung jawab atas segala sesuatu yang telah dipilihnya dengan segala risiko merupakan sikap yang paling tinggi.

Pengindikasian sikap seseorang merasa senang atau tidak senang terhadap matematika, pengkajiannya ini tertuang dalam disposisi matematis. Menurut Kilpatrick, Swafford, dan Findell (2001) menamakan disposisi matematis sebagai productive disposition (disposisi produktif), yakni pandangan terhadap matematika sebagai sesuatu yang logis, dan mengahasilkan sesuatu yang berguna. Lebih lanjut dikatakannya, disposisi matematika adalah kecenderungan; i) memandang matematika sesuatu yang dapat dipahami; ii) merasakan matematika sebagai sesuatu yang berguna dan bermanfaat; iii) meyakini usahayang tekun dan ulet dalam mempelajari matematika akan membuahkan hasil; dan iv) melakukan perbuatan sebagai pebelajar dan pekerja matematika yang efektif. Polking (dalam Sumarmo, 2010) mengemukakan bahwa komponen disposisi matematik, yakni: 1) rasa percaya diri dalam menggunakan matematika, memecahkan masalah, memberi alasan dan mengkomunikasikan gagasan; 2) fleksibilitas dalam menyelidiki gagasan matematik dan berusaha mencari metoda alternatif dalam memecahkan masalah; 3) tekun mengerjakantugas matematik; 4) minat, rasa ingin tahu (curiosity), dan dayatemu dalam melakukan tugas matematik; 5) cenderung memonitor, merepleksikan performance dan penalaran mereka sendiri; 6) menilai aplikasi matematika ke situasi lain dalam matematika dan pengalaman seharihari; 7) apresiasi (appreciation) peran matematika dalam kultur dan nilai, matematika sebagai alat danbahasa.

Berdasarkan uraian di atas, tertuanglah pertanyaan yang akan dibahas dalam tulisan ini, yaitu: Bagaimana mengeksplorasi sikap mahasiswa pendidikan matematika dalam pembelajaran matematika? Dengan tujuan memperoleh gambaran secara teoritis kecendrungan sikap mahasiswa pendidikan matematika dalam pembelajaran matematika.

\section{Metode Penelitian}

Pengkajian yang digunakan untuk menjawab pertanyaan "bagaimana mengeksplorasi sikap mahasiswa pendidikan matematika dalam pembelajaran matematika?". Pengkajian bersifat kualitatif bertumpu pada suatu fokus masalah. Menurut Moleong (2007: 93) masalah merupakan suatu keadaan yang bersumber dari hubungan antara dua faktor atau lebih yang menghasilkan situasi yang menimbulkan tanda tanya dan dengan sendirinya memerlukan upaya untuk mencari suatu jawaban. Fokus kajiannya adalah: 1) sikap yang utuh terbentuk dari tiga komponen pokok, yakni: a) kepercayaan (keyakinan), ide dan konsep terhadap suatu objek, b) kehidupan emosional atau evaluasi terhadap suatu objek, dan c) kecenderungan untuk bertindak; 2) sikap berdasarkan tingkatannya, yakni: i) menerima artinya subjek memperhatikan stimulus yang diberikan, ii) merespon artinya memberikan jawaban apabila ditanya, mengerjakan danmenyelesaikan tugas yang diberikan, iii) menghargai artinya mengajak orang lain untuk mengerjakan atau mendiskusikan suatu masalah, dan iv) berrtanggung jawab atas segala sesuatu yang telah dipilihnya dengan segala risiko merupakan sikap yang paling tinggi. 
Vol 2 No 2 Desember 2021

Jurnal AlphaEuclidEdu

Received: 23/09/2021; Resived: 01/10/2021; Accepted: 27/12/2021

Penjaringan dan pengumpulan data menggunakan intrumen non-tes, yakni angket. Menurut Sanjaya (2013:255), angket merupakan instrumen berupa daftar pertanyaan atau pernyataan secara tertulis yang harus dijawab atau diisi oleh responden sesuai dengan petunjuk pengisian. Penyusunan angket ini, memerlukan format kisi-kisi yang memuat definisi secara teoritis; definisi konseptual; definisi operasional; indikator; dan item pernyataan favorable/unfavorable. Setiap item pernyataan dalam angket diberikan pilihan tanggapan dengan menggunakan skala likert,yakni Sangat Setuju (SS); Setuju (S); Ragu- Ragu (R); Tidak Setuju (TS); dan SangatTidak Setuju (STS).

Beberapa kriteria yang harus diperhatikan dalam menyusun pernyataan untuk mengungkapkan sikap seseorang terhadap suatu objek, sehingga dapat memperoleh jawaban yang benar-benar diharapkan, setiap pernyataan yang diajukanhendaknya tidak meragukan dan menimbulkan tafsiran lain. Edward (1969: 13-14) mengemukakan kriteria tersebut sebagai berikut: a) arahkanlah pernyataan yang dikemukakan yang berhubungan dengan kondisi aktual, tidak mengungkapkan hal-hal yang sifatnya basi; b) hindarkan pernyataan yang merupakan suatu fakta atau dapat dianggap fakta, sehingga tidak mengungkapkan sikap; c) pernyataan hendaknya tidak mengandung arti yang bermacam-macam sehingga membingungkan; d) pernyataan hendaknya relevan dengan aspek psikologi yang akan dievaluasi; e) hindarkan pernyataan yang akan disetujui oleh semua responden, atau sebaliknya; f) susunlah pernyataan dalam bahasa yang sederhana, jelas dan langsung pada pokok masalah serta disajikan diusahakan singkat; g) tiap pernyataan diusahakan hanya memuat satu pokok pikiran; h) hindari kata-kata yang sifatnya universal, seperti semua, setiap, selalu, tak satupun, atau tak pernah sehingga tidak menimbukan keraguan; i) hati-hati menulis pernyataan dengan menggunakan kata "hanya" dan sejenisnya; j) usahakan menyusun pernyataan dengan kalimat tunggal; k) gunakan kata-kata yang sudah banyak dikenal agar tidak menyesatkan; dan 1) hindarkan menggunakan pernyataan yang mengandung kata negatif lebih dari satu kali.Data hasil angket yang diperolah berasal dari tanggapan mahasiswa, dianalisismenggunakan peskoran sesuai dengan skalalikert.

Analisis ini menyatakan kesetujuan dan ketidak setujuan responden pada lima kategori pilihan dengan tujuan untuk mempertegas pilihan responden. Kelima kategori tersebut, yakni item favorable: skor 4 untuk memilih "Sangat Setuju (SS)"; skor 3 untuk memilih "Setuju (S)"; skor 2 untukmemilih "Ragu-Ragu (R)"; skor 1 untuk memilih "Tidak Setuju (TS)"; dan skor 0untuk memilih "Sangat Tidak Setuju (STS)". Sedangkan untuk item unfavorable berlaku penskoran kebalikan dari favorable. Penskalaan dengan metode likert dalamanalisis ini berbantukan deviasi normal dengan tujuan untuk memberi bobot yang tertinggi bagi kategori jawaban yang favorabel dan memberi bobot rendah pada jawaban yang tidak favorable (Syaifuddin, 2010:141).

Proses penentuan nilai skala, yaitu: 1) membuat tabel distribusi responden; 2) membuat tabel nilai skala kategori jawaban untuk setiap pernyataan, dengan tahapan untuk menentukan nilai skala, di antaranya: a) menghitung frekuensi (f) jawaban responden untuk masing-masing kategori respon; b) menghitung proporsi (p) masingmasing respon dengan cara membagi frekuensi pada tiap respon dengan jumlah responden keseluruhan; c) menghitung proporsi kumulatif (pk); d) menghitung titik tengah proporsi kumulatif (pkt); e) mencari nilai $\mathrm{z}$ dari tabel deviasi normal; $\mathrm{f}$ ) menentukan titik nol pada respon paling kiri atau paling rendah; dan g) melakukan pembulatan harga z. Selanjutnya melakukan tahapan untuk setiap item pernyataan: 3) 
Vol 2 No 2 Desember 2021

Jurnal AlphaEuclidEdu

Received: 23/09/2021; Resived: 01/10/2021; Accepted: 27/12/2021

menentukan interval untuk menggolongkan responden pada kategori yang sesuai dengan pilihannya; dan 4) menentukan skala responden.

\section{Hasil dan Pembahasan}

Pendidik/dosen yang mencintai profesinya demi kemajuan mahasiswa tidak akan merobohkan pilar pembelajaran. Selain itu, dosen yang profesional tentu selalu mencerminkan prilaku yang dapat di tauladani oleh mahasiswa, seperti berbahasa dengan bijak, dengan baik dan benar, dengan bahasa yang indah-indah, serta dengan sopansantun akan menumbuhkan pikiran dan sikappositif, menumbuhkan keakraban dan mempererat persaudaraan, menumbuhkan simpati dan empati, menjauhkan lawan bicara dari rasa tertekan atau terintimidasi (Chairil, 2012:9). Prilaku-prilaku dosen yang dipaparkan tersebut dapat mempengaruhi sikap dan prilaku serta kemampuan belajar mahasiswa.

Tujuan pembelajaran bukanlah penguasaan materi semata, namun lebih jauh proses penguasaan materi dapat membentuk prilaku mahasiswa itu sendiri. Proses pembelajaran untuk membentuk prilaku mahasiswa yang baik sangat dipengaruhi oleh kondisi kewibawaan dan kewiyataan yang ada pada diri dosen selaku pendidik. Karena kondisi tersebut merupakan pilar pembelajaran. Kewibawaan dapat tercipta, jika dosen mampu membangun sentuhan yang tinggi terhadap mahasiswa sehingga terciptanya rasa aman dan nyaman bersama pendidiknya. Untuk mengkondisikan rasa aman dan nyaman dalam belajar ini, sangat perlu memperhatikan unsur-unsur kewibawaan, yaitu: 1) pengakuan dan penerimaan; 2) kasih sayang dan kelembutan; 2) penguatan; 4) tindakan tegas yang mendidik; dan 5) pengarahan dan keteladanan. Sementara unsurunsur yang ada pada kewiyataan, yaitu: 1) penguasaan materi pembelajaran; 2) penerapan metode pembelajaran; 3) penggunaan alat bantu pembelajaran; 4) pengembangan lingkungan pembelajaran; dan 5) penyelenggaraan penilaian pembelajaran (Phil Y.K., 2012:110).

Selanjutnya, membangun sikap mahasiswa yang mumpuni setidaknya memerlukan tiga hal, yaitu: keteladanan, pembiasaan, dan pengontrolan. Keteladan, dapat diwujudkan dalam proses pembelajaran dengan menginternalisasikan nilai-nilai, seperti: keberanian, kejujuran, percaya diri, tanggungjawab, kerendahan hati, saling menghargai. Pembiasaan, prosesnya dapat diwujudkan melalui membiasakan dengan mengulang-ulang nilai yang diinternalisasikan dalam diri seseorang. Pengontrolan, prosesnya senantiasa memberikan penghargaan (reward) pada mahasiwa yang berprestasi sebagai penyemangat/motivator, dan pemberian sanksi (punishment) bagi mereka yang kurang memberikan perhatian (Arif Rachman, 2015). Artinya, membangun sikap tidak lepas dari kesadaran dari tugas pendidik/dosen yang bukan hanya membuat pembelajar menjadi pandai, tetapi juga membekali mereka dengan nilai-nilaikehidupan untuk mempersiapkan dalam menghadapi tantangan masa depan.

Penginternalisasian nilai-nilai ini mempengaruhi pembentukan kepribadian atau karakter mahasiswa. Lickona (1991) menyatakan pandangannya bahwa karakter terbentuk melalui proses knowing the good, feeling the good, acting the good. Pandangan ini memberikan implikasi bahwa dalam pembentukan dan pengembangan karakter melalui proses pemahaman, menghayati/meyakini, dan mewujudkan nilai karakter dalam perbuatan. Selanjutnya, Kilpatrick (Muslich, 2011:133) menyatakan bahwa seseorang mempunyai kebajikan (moral knowing) namun harus mampu 
Vol 2 No 2 Desember 2021

Jurnal AlphaEuclidEdu

Received: 23/09/2021; Resived: 01/10/2021; Accepted: 27/12/2021

mewujudkan pemahamannya melalui pembiasaan menjadi perilaku baik (moralaction). Pewujudan moral knowing menjadi moral action memerlukan moral feeling. Maksudnya, kemampuan meyakini apa yang diketahui seseorang terhadap kebajikan itu mampu merubah pengetahuannya menjadi perilaku baik. Kemampuan terhap moral knowing dan moral feeling menjadi moral action memerlukan latihan atau pembiasaan. Penanaman nilai-nilai moral kowing, moral feeling dan moral action diharapkan dapat membentuk kepribadian seseorang yang mempunyai perilaku mandiri dapat memutuskan tindakan yang berasal dari kebajikan dalam dirinya. Sehingga sikap dan tindakan yang dilakukan mengarah pada pembentukan dan pengembangan kepribadian atau karakter seseorang.

\section{Kesimpulan}

Sikap atau perilaku pengertiannya secara umum dianggap sama, hal ini ada benarnya karena sikap dan perilaku sama sama merupakan respon yang ditunjukkan dengan reaksi sesuai karakter dari seseorang yang melakukannya. Namun dalam psikologi terdapat perbedaan makna antara sikap dan perilaku. Manifestasi sikap tidak dapat langsung dilihat, melainkan ditafsirkanterlebih dahulu sebagai tingkah laku, sikap sering dihadapkan pada rangsang sosial dan reaksi yang bersifat emosional. Dengan kata lain, bahwa sikap bukan merupakan suatu tindakan melainkan merupakan kecenderungan perilaku.

Pengeksplorasian sikap mahasiswa dalam pembelajaran matematika dapat digunakan sebagai wahana untuk memahami karakter mahasiswa. Sikap itu merupakan kesiapan untuk bereaksi terhadap objek di lingkungan tertentu dan sebagai suatu penghayatan terhadap objek. Terdapat tiga komponen pokok yang secara bersama-sama membentuk sikap yang utuh, yakni: a) kepercayaan terhadap suatu objek, b) kehidupan emosional atau evaluasi terhadap suatu objek, dan c) kecenderungan untuk bertindak. Pemahaman terhadap sikap mahasiswa akan memudahkan untuk berinteraksi dalam proses pembelajaran.

Perilaku ketauladan, pembiasaan dan koreksi atau kontrol sangat diperlukan untuk menegakkan pilar pembelajaran matematika,karena prilaku tersebut akan muncul dan memancarkan nilai edukatif. Nilai tersebut selalu terpancar, jika pendidik/dosen tidakhanya bertindak sebagai pentransfer ilmu pengetahuan intelektual subjek didiknya saja,melainkan pendidik yang dapat memberdayakan dan mengembangkan pengetahuan subjek didiknya secara utuh/komprehensip.

\section{Referensi}

Arif Rachman (2015). Guru Berdasarkan Catatan Ukim Komarudin, Penerbit Erlangga. Bambang, H. (2007). Representasi dalam Pembelajaran Matematika. Pontianak: STAIN Pontianak Press.

Chairif E. (2012). Peranan Bahasa Melayu dalam MembangunKarakter Bangsa, Bahan SeminarNasional di Hotel AstonPontianak Tgl 5-6 Juni 2012.

Kilpatrick, J., Swafford, J., \& Findell, B. (2001). Adding it up: Helping children learn mathematics. Washington, DC. : NationalAcademy Press.

Lickona, T. (1991). Educating For Character How Our Schools Can Teach Respect AndResponsibility. New York : Simon\& Schuster, Inc.

Muslich, M. (2011).Pendidikan Karakter Menjawab Tantangan Krisis 
Vol 2 No 2 Desember 2021

Jurnal AlphaEuclidEdu

Received: 23/09/2021; Resived: 01/10/2021; Accepted: 27/12/2021

Multidimensional. Jakarta:PT. Bumi Aksara.

Soedjadi, R. (2004). Designing Instruction of Values in SchoolMathematics, Surabaya: FPMIPAUNESA.

Sumarmo, U. 2010. Berfikir dan Disposisi Matematik: apa, Mengapa, dan Bagaimana dikembangkan pada Peserta Didik. https://www.scribd.com/doc/763 53753/Berfikir-DanDisposisi- Matematik-Utari [on-line diunduh12-06-2021].

Yulis J., dkk (2013). Pengembangan Model Pembelajaran Matematika Humanis Sederhana Berbasis Pendidikan Karakter BagiMahasiswa Pendidikan Matematika FKIP UntanPontianak. Laporan Penelitian. , (2006). Deskripsi SikapMahasiswa Semester VI Jurusan PMIPA Program Studi Pendidikan Matematika Terhadap Mata Kuliah Struktur Aljabar.Laporan Penelitian. 
Vol 2 No 2 Desember 2021

Jurnal AlphaEuclidEdu

Received: 05/05/2021; Resived: 11/10/2021; Accepted: 28/12/2021

\title{
KAJIAN ETNOMATEMATIKA DALAM TRADISI PERNIKAHAN MASYARAKAT DAYAK KANAYATN DI KECAMATAN TOHO KABUPATEN MEMPAWAH
}

\author{
Eka, Sugiatno, Munaldus \\ Program Studi Pendidikan Matematika FKIP Untan Pontianak \\ Email: $\underline{\text { ekamrdn98@gmail.com }}$
}

\begin{abstract}
The purpose of the research is to know Dayak Kanayatn Custom as a mathematical aspect in Marriage related to ethnomathematics studies to be used in mathematics learning in schools and mathematical aspects contained in the wedding tradition. The seven subjects in the study were: 1 patent expert', 1 patone's helper, executing subject: 1 perias, 2 male parents, 2 female parents. The object of the research is the Wedding Tradition of Dayak Kanayatn People in Toho Subdistrict, Mempawah Regency. Qualitative descriptive type research. Data from research subjects' interviews and activities carried out by the Dayak Kanayatn community of Toho Subdistrict, Mempawah Regency. They then reviewed the mathematical aspects based on six basic mathematical activities-one mathematical aspect of the dominant, namely numerate. The saying is seen when Patone' performs nyangahatn, which aims to plead with Jubata to intervene in the Marriage. Pantone' started the activity of saying: asa', dwa, talu, ampat, lima, anam, seven. The number seven is the highest number, meaning fulness.
\end{abstract}

Keywords: Ethnomatematic Studies, Wedding Traditions, Dayak Kanayatn Society

\section{Pendahuluan}

Sukar untuk disangkal bahwa pendidikan terkait dengan proses budaya. Proses ini berlaku untuk semua materi pelajaran termasuk pelajaran matematika. Etnomatematika pada dasarnya merupakan nilai-nilai matematika yang diimplementasikan oleh para leluhur diberbagai belahan dunia dalam melaksanakan aktivitasnya sehari-hari. Sebagaimana diungkapkan oleh para ahli di National Council of Teachers of Mathematics (NCTM) bahwa dalam belajar, membangun hubungan antara budaya sosial, kehidupan pribadi, serta matematika sangatlah penting (NCTM, 2000).

Hubungan yang dapat membangun matematika dan budaya satu diantaranya adalah konsep-konsep etnomatematika yang ditemukan dalam tiap-tiap daerah dan dikelompok budaya tertentu, dan dapat dikombinasikan dalam pembelajaran tingkat sekolah dasar maupun tingkat sekolah menengah pertama. Matematika pada kelompok budaya disebut juga dengan istilah etnomatematika (D'Ambrosio, 1989). 6 aktivitas yang terdapat dalam kajian etnomatematika, yaitu: Aktivitas Membilang, Aktivitas Mengukur, Aktivitas Menentukan Lokasi, Aktivitas Membuat Rancang Bangun, Aktivitas Bermain, serta Aktivitas Menjelaskan.

Istilah etno dapat digambarkan melalui semua hal yang berbentuk identitas dalam budaya-budaya suatu kelompok, yaitu kebiasaan dan sifat-sifat fisik, keyakinan, nilainilai, kode, bahasa, makanan dan pakaian. Sedangkan matematika itu sendiri mencakup pandangan yang sangat luas mengenai mengurutkan, mengklarifikasi, modeling, dan menyimpulkan. Etnomatematika sangat berfungsi untuk mengekspresikan suatu hubungan antara budaya dan matematika. Melalui pernyataan tersebut dapat diambil kesimpulan, bahwa Etnomatematika merupakan ilmu yang dapat digunakan untuk menjelaskan bagaimana matematika itu dapat di adaptasikan dengan sebuah kebudayaan (Marsigit, 2016); (Panjaitan et al., 2021). 
Vol 2 No 2 Desember 2021

Jurnal AlphaEuclidEdu

Received: 05/05/2021; Resived: 11/10/2021; Accepted: 28/12/2021

National Academy of Sciences dalam (Orey, 2006), menjelaskan bahwa budaya mempunyai keberagaman. Keberagaman dalam budaya ini merupakan faktor yang dapat memperkuat dan dapat memberi pengaruh terhadap pembentukan karakter-karakter siswa, bagaimana cara mereka berpikir dalam memahami kehidupan dan dunia yang mereka jalani, dan bagaimana cara mereka untuk menginterpretasikan pengalamannya, bahkan pengalaman orang lain. Oleh sebab itu, pendapat yang dikemukakan oleh (Orey, 2006), bahwa budaya dapat memberi pengaruh terhadap cara memperoleh dan menggunakan pengetahuan terhadap matematika, sehingga strategi dalam etnomatematika dapat diterapkan, yang bertujuan untuk menciptakan dan mengintegrasikan antara budaya yang dimiliki oleh siswa dan matematika dalam suatu pembelajaran matematika.

Etnomatematika merupakan suatu kajian yang mempelajari cara orang dalam mengartiku-lasikan, memahami, serta menggunakan konsep-konsep dan praktik-praktik pada budaya tertentu yang melambangkan segala sesuatu yang matematis. Barton (1996:196), berpendapat bahwa etnomatematika adalah suatu bidang kajian dalam penelitian. Etnomatematika bukanlah matematika dari kelompok budaya tertentu, sebab matematika bukan kumpulan-kumpulan dari bagian matematika yang terpisah, masingmasing satukan dari kelompok yang berbeda-beda. Melainkan etnomatematika merupakan bidang kajian penelitian yang mempelajari suatu ide-ide matematika dalam konteks budaya.

Begitu pula dengan pendapat Orey (2006), mengenai etnomatematika, Ia berpendapat bahwa etnomatematika merupakan himpunan bagian antara antropologi budaya, matematika institusional, dan pemanfaatan pemodelan matematika, yaitu untuk memecahkan masalah nyata serta menerjemahkannya kedalam sistem bahasa matematika. Penyelidikan tentang apa itu budaya merupakan salah satu kajian etnomatematika. Budaya yang menggunakan ide-ide dalam suatu kelompok tertentu.

Implikasi etnomatematika pernikahan merupakan sebuah ikatan yang sah untuk membina rumah tangga dan berkeluarga, karena kedua suami istri bertanggung jawab terhadap keduanya dan anak-anaknya. Pada dasarnya, pernikahan Adat yang dilaksanakan oleh Suku Dayak Kanayatn di Kecamatan Toho, Kabupaten Mempawah, mempunyai bentuk pernikahan yang dipengaruhi oleh sistem kekeluargaan yang bersifat Parental. Parental yang dimaksud adalah sistem kekeluargaan yang menarik garis keturunan baik dari pihak keluarga Ibu maupun dari pihak keluarga Bapak (Nana, 2006).

Puntor (55 tahun) mengemukakan bahwa di Kecamatan Toho khususnya di Desa Sepang, tradisi pernikahan merupakan sebuah acara yang wajib di laksanakan jika ada yang ingin menikah. Dalam hal ini, pernikahan tersebut dilakukan secara ber-Adat. Adat Dayak Kanayatn. Adat kebudayaan Dayak Kanayatn yang selalu digunakan saat prosesi pernikahan akan digelar. Ernst Cassirer (dalam Wahyuni, 2013), mengemukakan bahwa ada 5 aspek dalam kebudayaan, yaitu: (i) Kehidupan spiritual, (ii) Bahasa dan kesastraan, (iii) Kesenian, (iv) Sejarah, dan (v) Ilmu pengetahuan.

Pengetahuan akan dapat berkembang jika matematika yang ada merupakan gagasan dari etnomatematika itu sendiri. Oleh sebab itu, jika pengetahuan mengenai gagasan etnomatematika telah berkembang, maka akan banyak yang melakukan penyelidikan, sehingga matematika dapat diajarkan secara bersahaja dengan mengambil budaya setempat. 
Vol 2 No 2 Desember 2021

Jurnal AlphaEuclidEdu

Received: 05/05/2021; Resived: 11/10/2021; Accepted: 28/12/2021

Budaya yang dimaksud di sini adalah Adat-Istiadat dalam tradisi pernikahan masyarakat Dayak Kanayatn di Kecamatan Toho. Menyangkut masalah sesajian (palantar) yang di hidangkan, pakaian pengantin yang digunakan beserta alat-alat, serta persiapan dalam melaksanakan upacara pernikahan. Penelitian terkait yang dilakukan oleh Sana (2018), ber judul "Perkawinan Adat Dayak Ma'anyan Sebagai Ujud Pendidikan Masyarakat Kalimantan Tengah". Penelitiannya menemukan: Pernikahan merupakan se-suatu yang kodratnya baik dari aspek kebutuhan biologis maupun sosial. Dilihat dari kebutuhan biologis, pernikahan mengarah kepada upaya untuk meneruskan keturunan; sedangkan dari struktur sosial mengarah kepada kelembagaan tradisi atau Adat yang ada di masyarakat.

Penelitian lain dilakukan oleh Noriana (2019), berjudul "Perkawinan Adat Masyarakat Muslim Suku Dayak Ngaju: Sejarah dan Akulturai Islam Terhadap Budaya Lokal di Desa Petak Bahandang". Dalam penelitiannya menemukan: Di Desa Bahandang dalam melaksanakan prosesi pernikahan telah terjadi perubahan, khususnya simbol non-verbal sebagai akibat dari perkembangan jaman dan interaksi antar masyarakat serta masyarakat dalam pernikahan Adat sebagai prosesi yang sakral dari leluhur terdahulu dan masih dilaksanakan hingga sekarang. Dalam penelitiannya Noriana juga mengemukakan, bahwa Suku Dayak Ngaju khususnya umat Muslim berpandangan bahwa Agama dan ke-budayaan merupakan dua hal saling berinteraksi dan saling memberi pengaruh, karena pada keduanya terdapat suatu nilai dan simbol.

Penelitian yang telah dikemukakan di atas dan penelitian yang akan diteliti saat ini memiliki kesamaan konsep, yaitu eksplorasi bentuk-bentuk etnomatematika yang terdapat dalam tradisi pernikahan. Matematika sebagai budaya telah terintegrasi pada segala aspek yang berkaitan dengan pola hidup masyarakat dimanapun mereka tinggal. Maka dapat dikatakan matematika seseorang dapat dipengaruhi oleh lingkungan budaya setempat, sebab apa yang mereka kerjakan berdasar dari apa yang mereka lihat dan mereka rasakan. Budaya sangat berpengaruh bagi prilaku atau sikap individu seseorang dan mempunyai gagasan yang sangat penting pada perkembangan pemahaman individualismenya, termasuk dalam pembelajaran matematika itu sendiri. Pada dasarnya pembelajaran matematika telah menyatu (berkaitan) dengan kehidupan kita sehari-hari.

Budaya dan pendidikan adalah se-suatu yang saling berkaitan. Pendidikan maupun budaya dipandang sebagaimana cara masyarakat mewarisi (mewariskan) tradisi, menemukan gagasan baru dan berevolusi dari generasi ke generasi. Penggunaan budaya dalam pendidikan matematika dapat terjadi karena: (i) Belajar melalui budaya, merupakan penggunaan budaya sebagai sarana dalam belajar, dan (ii) Belajar dengan budaya, merupakan penggunaan budaya sebagai sumber belajar.

Secara umum, prosesi pernikahan Adat Dayak Kanayatn dimulai dengan pinangan dan diakhiri dengan membongkar tingkalakng (seserahan). Terdapat juga beragam ritual yang harus dilaksanakan. Dalam pernikahan Dayak Kanayatn di Desa Sepang tersebut, sangat melarang sebuah pernikahan dilakukan jika kedua mempelai yang masih terikat dengan keluarga. Namun, ada beberapa yang terkadang rela melanggar aturan dengan membayar hukum Adat (denda) sebagai tebusan atas aturan yang mereka langgar. Unsur-unsur matematika yang terkandung dalam ritual pernikahan Adat Dayak Kanayant ini yaitu: jumlah 1 pahar, dalam pahar ini terdiri dari: 2 mangkuk putih, 1 piring yang berisi 7 cucur/tumpi, beras poe'/pulut yang ada dalam 1 bambu, 7 bontokng, 1 piring putih, 3 ayam, 1 babi, 3 cangkir untuk melengkapi Adat. 
Vol 2 No 2 Desember 2021

Jurnal AlphaEuclidEdu

Received: 05/05/2021; Resived: 11/10/2021; Accepted: 28/12/2021

Materi pada hantaran yang dikemaskan yaitu: 7 nasi yang dibungkus dengan daun simpur, 7 nasi pulut yang dibungkus dengan daun layakng, 8 tumpi' (cucur) dibungkus juga dengan daun layakng, 7 ruas sengkatek nasi pulut yang dimasak dalam ruas bambu muda, 1 garam, 1 gula aren (gula enau), 7 linting (gulung) rokok daun, 7 tembakau hitam, dan 7 buah pinang, daun sirih, gembir, dan kapur sirih secukupnya.

Dalam pelaksanaan pernikahan, rombongan mempelai pria akan berangkat menuju rumah mempelai perempuan, namun sebelum berangkat menuju rumah mempelai perempuan, Patone' akan membacakan doa baras banyu terlebih dahulu, yang berbunyi: 'A koa iant kita' Ene' Daniang, Pana Ne' Nange Patampa', Ne' Pajaji, Ne' Pengedokng, Ne' Taratatn, Ne' Amikng, Ne' Pamijar nang nonokng ngalompa; kami talino manusia tamula idup tamula jaji, Siti Awa, Nabi Adam, iant aku maca mamangan baras banyu baras cuci baras aning naing jakita' pama Jubata. Nianlah kami babatak bajahula batampak batarakng ka' kita'. Karana ari naing kami nurutatna' panganten da' Edot dan Rosa, jaji nian unang ia dah turutna' panganten kami minta baras banyu nian kade' ka' pucuk jaji payukng jaji tono'. Kade' ka' tubuh ka' badan ia jaji gunapm barote' jaji palincir palias. Kade' ia ka' tanah ka' saka ka' maraga jaji sabar kuta benteng pagar talutuk jaji jojo danatn. Kade' ada setan ibalis nang ngaco nang ngarua' kami mintak baras banyu nianlah nang mampu mampi' madapnmnya. Karana kami mangka make baras banyu nian Jubata bukaatn uga' numbuh namula mobok marompokng. Nianlah baras banyu nang turutn di ne' Unte' Tanyukng Bunga sae' di Sabaka Samatn di Turintikng Angge Pauh Janggi Petor Kalimantan Tungal nang ngajaratnnya $k a$ ' kami talino manusia Jubata. Kade' panganten nian bajalatn ampa bajalatn $k a^{\prime}$ bide ka' papatn poa' duri poa' onak. Sampe atakng ia ka' rumah nang bibi nang yaknya binia', atakng baraseh atakng salamat. Ahe agi' ke' ia nang pangantena' sampe uga' ka' Pucaranya sampe uga' ka' kami nang ngayukngi'nya sampe uga' $k a$ ' nang bini nang diatakngia' sama baraseh sama salamat nian bah nang kami minta kami mulih Jubata. Asa' dua talu ampat lima anam tujuh koa bajalatn nang kao dolo' baras banyua. Kade' ada jangkang raba' setan balis kao salabih dolo' ngege ngais nyiang muka' ngaramaknya ame ia jaji pangaco pangaru ka' talino manusia jakita' Pama....Jubata".

Artinya: "Ya Tuhan Ya Allah Engkau yang menciptakan dunia ini serta isinya, juga engkau yang menciptakan kami dari tanah liat dan memberi kami nafas kehidupan pada manusia yang pertama Nabi Adam dan Siti Awa. Dengarlah doa kami dengan beras banyu yang 7 biji ini. Biarlah Engkau memberkati beras kuning ini agar menjadi pelindung kami di tengah-tengah perjalanan nanti. Ya Tuhan, karena kami pada hari ini akan menghantarkan mempelai laki-laki kerumah mempelai perempuan yang sekaligus pada hari ini pula akan melangsungkan pernikahan. Tuhan, lindungilah kami semuanya. Tuhan juga mau melindungi mempelai perempuan beserta kaum berkumpul bersamasama dalam keadaan selamat ya Tuhan. Satu dua tiga empat lima enam tujuh, berjalanlah engkau beras banyu yang tujuh biji, karena engkau sudah diberkati oleh Tuhan Yang Maha Kuasa. Biarlah jika engkau diatas menjadi tudung bagi kami. Kalau engkau berada di badan kami biarlah engkau menjadi perisai untuk menyelamatkan kami dari godaan setan iblis. Satu dua tiga empat lima enam tujuh ya...Tuhan".

Etnomatematika mempunyai kerangka, yaitu: Culltural Antropology, Mathematics, Mathematics Modeling. 
Vol 2 No 2 Desember 2021

Jurnal AlphaEuclidEdu

Received: 05/05/2021; Resived: 11/10/2021; Accepted: 28/12/2021

\section{Metode Penelitian}

Penelitian ini menggunakan metode penelitian kualitatif dengan pendekatan etnografi. Hal tersebut dimaksudkan agar dapat mendeskripsikan hasil eksplorasi konsep matematika yang ada pada aktivitas membilang dalam tradisi pernikahan Daya Kanaytn di Desa Sepang, Kecamatan Toho, Kabupaten Mempawahdan dapat mengaplikasikannya kedalam proses pembelajaran matematika.

Terdapat tujuh subjek yang terlibat dalam penelitian ini, yaitu subjek ahli 1 patone', 1 pembantu patone', sedangkan subjek pelaksana yaitu 1 ahli dalam merias, 2 orang tua pengantin mempelai pria, dan 2 orang tua pengantin mempelai wanita.Objek dari penelitian ini yaitu Tradisi Pernikahan Masyarakat Dayak Kanayatn di Kecamatan Toho, Kabupaten Mempawah.

Merancang proposal penelitian adalah langkah awal dalam prosedur penelitian ini, setelah merancang proposal penelitian kemudian dilanjutkan dengan pendeskripsian hasil wawancara dengan 7 subjek penelitian, selanjutnya ditarik kesimpulan agar rumusan masalah yang telah diumuskan dapat terjawab dengan baik.

Penelitian ini dilakukan ditempat kediaman Bapak Molana, yang beralamat di Desa Sepang, Kecamatan Toho, Kabupaten Mempawah. Penelitian ini dilakukan saat putera pertama dari Bapak Molana menikah dengan cara ber-Adat. Penelitian ini dilaksanakan selama 3 hari pada tanggal 18-20 April 2021.

Bentuk wawancara merupakan data yang di peroleh dalam penelitian ini. Berikut adalah beberapa pertanyaan utama yang peneliti tanyakan kepada subjek ahli (Patone') mengenai tradisi pernikahan yang dilaksanakan:

\begin{tabular}{|c|c|}
\hline Pertanyaan & Jawaban \\
\hline $\begin{array}{l}\text { Tadi saat bapak melakukan nyangahatn } \\
\text { saya mendengan bahwa bapak } \\
\text { mengawalinya dengan asa, dwa, talu, } \\
\text { ampat, lima, anam, tujuh. Maksudnya } \\
\text { apa? }\end{array}$ & $\begin{array}{l}\text { "Kata asa, dwa, talu, ampat, lima, anam, } \\
\text { tujuh ini mempunyai arti bahwasannya } \\
\text { kita ingin memulai berinteraksi dengan } \\
\text { Jubata agar turut campur dalam } \\
\text { pelaksanaan pernikahan ini." }\end{array}$ \\
\hline Mengapa diakhiri dengan angka tujuh? & $\begin{array}{l}\text { "Karena memang tadisi kita seperti ini, } \\
\text { tradisi yang telah dilakukan turun } \\
\text { temurun" }\end{array}$ \\
\hline Mengapa tidak ada angka nol? & $\begin{array}{l}\text { "Karena dalam pelaksanaan nyangahatn } \\
\text { tidak mengenal angka nol." }\end{array}$ \\
\hline $\begin{array}{l}\text { Apa itu Adat dalam tradisi pernikahan } \\
\text { Dayak Kanayatn? }\end{array}$ & $\begin{array}{l}\text { "Adat dalam tradisi pernikahan Dayak } \\
\text { Kanayatn merupakan sebuah ritual (ritual } \\
\text { nyangahatn)." }\end{array}$ \\
\hline
\end{tabular}

Instrument utama pada penelitian ini adalah peneliti sendiri, dan instrument lainnya merupakan instrumen pendukung, berupa: kamera, alat rekam, pertanyaan wawancara.

\section{Hasil Dan Pembahasan}


Vol 2 No 2 Desember 2021

Jurnal AlphaEuclidEdu

Received: 05/05/2021; Resived: 11/10/2021; Accepted: 28/12/2021

Berdasarkan wawancara kepada 7 subjek pada tanggal 18-20 April 2021, peneliti menemukan satu aspek matematis yang dominan, yaitu membilang. Aspek membilang nampak ketika Patone' (pemimpin upacara) melakukan aktifitas nyangahatn. Nyangahatn bertujuan memohon kepada Jubata agar turut campur dalam pelaksanaan Pernikahan. Patone' (pemimpin upacara) mengawali dengan aktifitas membilang: asa', $d w a$, talu, ampat, lima, anam, tujuh. Angka tujuh merupakan angka paling tinggi yang mempunyai makna kegenapan (keterlibatan Jubata dalam pelaksanaan pernikahan).

Penelitian ini bertujuan untuk mengetahui Adat Istiadat Dayak Kanayatn sebagai aspek matematis dalam prosesi pernikahan yang berkaitan dengan kajian etnomatematika, sehingga dapat digunakan dalam belajar mengajar matematika disekolah dan tidak harus terpaku dengan bahan ajar, melainkan dari kebiasaaan seharihari juga dapat dikaitkan dengan pembelajaran, khususnya pembelajaran matematika.

Contoh: kebiasaan dalam mengikuti sebuah tradisi pernikahan yang diadaka. Sebuah tradisi atau kebiasaan yang sering kali diadakan dari tahun ketahunnya. Begitu pula dengan masyarakat Dayak Kanayatn di Desa Sepang Kecamatan Toho, Kabupaten Mempawah, yang selalu mengadakan tradisi pernikahan jika ada sanak saudaranya yang hendak disatukan sehingga tercipta sebuah keluarga. Dalam pelaksanaan tradisi pernikahan di Desa Sepang, Kecamatan Toho ini menemukan sebuah aspek yang lebih dominan, yaitu membilang.

\section{Simpulan}

Berdasarkan hasil penelitian dapat di ambil kesimpulan: Dalam pelaksanaan pernikahan Dayak Kanayatn di Kecamatan Toho, Kabupaten Mempawah terdapat satu aspek yang dominan, yaitu membilang.

Aspek membilang ini nampak ketika Patone' melakukan nyangahatn yang diawali dengan ucapan: asa dwa talu ampat lima anam tujuh. Angka ujuh adalah angka paling tinggi yang mempunyai makna kegenapan.

\section{Referensi}

Barton, B. (1996). Making Sense Of Etnhomathematics: Ethnomathematics Is Making Sense. Educational Studies In Mathematics. [diakses, 11 Februari 2021].

D'Ambrosio, U. On ethnomathematics. 1989. Philosophica Mathematica (2) 4 no.1, 3 14 [diakses, 15 Februari 2021].

Hartoyo, A. 2012. Eksplorasi Etnomatematika pada Budaya Masyarakat Dayak Perbatasan Indonesia-Malaysia Kabupaten Sanggau Kalbar. Jurnal Penelitian Pendidikan, 13 (1) [diakses, 20 November 2020].

National Council of Teacher of Mathematics. (2000). Principles And Standarts For School Mathematics. School Science And Mathematics (Vol 47). [diakses, 25 Februari 2021].

Noriana, 2019 - Perkawinan Adat Masyarakat Muslim Suku Dayak Ngaju: Sejarah dan Akulturasi Islam Terhadap Budaya Lokal di Desa Petak Bahandang. [diakses, 20 November 2020].

Orey, Daniel Clark \& Rosa, Milton. 2006. Etnomathematics: Cultural Assertions And Challenges Towards Pedagogical Action. The Journal Of Mathematics And Culture. [diakses, 11 September 2020].

Panjaitan, S., Hartoyo, A., \& Fitriawan, D. (2021). Eksplorasi Etnomatematika Kain 
Vol 2 No 2 Desember 2021

Jurnal AlphaEuclidEdu

Received: 05/05/2021; Resived: 11/10/2021; Accepted: 28/12/2021

Tenun Songket Suku Melayu Sambas. Jurnal AlphaEuclidEdu, 2(1), 19-31. https://jurnal.untan.ac.id/index.php/AlphaEuclidEdu/article/view/47890

Puntor (usia 55 Tahun) Selaku Ketua Adat di Desa Sepang, Kecamatan Toho, Kabupaten Mempawah. [diakses, 25 September 2020].

Sintani Sana, 2018 - Perkawinan Adat Dayak Ma'anyan Sebagai Ujud Pendidikan Masyarakat. [diakses, 20 November 2020].

Wahyuni, A., dkk. 2013. Peran Etnomatematika dalam Membangun Karakter Bangsa. Prosiding ISBN : 978-979-16353-9-4. Makalah dipresentasikan dalam Seminar nasional Matematika dan Pendidikan Matematika dengan tema "Penguatan Peran Matematika dan Pendidikan Matematika untuk Indonesia yang Lebih Baik" [diakses, 15 Oktober 2020]. 
Vol 2 No 2 Desember 2021

Jurnal AlphaEuclidEdu

Received: 02/03/2021; Resived: 23/09/2021; Accepted: 28/12/2021

\title{
ANALISIS LITERASI NUMERASI PADA MATERI PERSAMAAN DAN PERTIDAKSAMAAN NILAI MUTLAK LINEAR SATU VARIABEL DIKAJI DARI KECERDASAN EMOSIONAL
}

\author{
Esa Sandi Putri, Edy Yusmin, Asep Nursangaji \\ Program Studi Pendidikan Matematika FKIP Untan Pontianak \\ Email:esasandiputri01@gmail.com
}

\begin{abstract}
This study aims to determine numeracy literacy in the material equations and inequalities of the absolute value assessed from the emotional intelligence of students at SMA Panca Setya Sintang. The method used in this research is descriptive with a case study research. The subjects in this study were students of grade X IPA 3 with a total of 17 students. The object to be researched is numeracy literacy in the material equations and inequality of the absolute linear value of one variable assessed from the emotional intelligence of students. The techniques used in data collection are questionnaires, numeracy literacy tests and interviews. The results obtained from this study that there were four students who had high levels of emotional intelligence and tended to have high numeracy literacy, eleven students had moderate emotional intelligence and also varied numeracy literacy with one student with good numeracy literacy, six students with good numeracy and four students with poor numeracy, and two students who had low levels of emotional intelligence and had low numeracy literacy.
\end{abstract}

Keywords: Numeracy Literacy, Emotional Intelligence, Equations And Inequalities Of The Absolute Value

\section{Pendahuluan}

Matematika merupakan mata pelajaran yang ada di setiap tingkatan pendidikan mulai dari Pendidikan Anak Usia Dini, Taman Kanak-Kanak, SD, SMP, maupunSMA. Dari tingkatan pendidikan paling awal anak-anak mulai dikenalkan dengan matematika. Misalnya pada anak usia dini mulai dikenalkan bilangan sederhana mulai dari 1 sampai 10. Matematika diharapkan dapat memberikan sumbangan dalam meningkatkan kemampuan peserta didik. Dalam hal ini telah dilakukannya berbagai upaya oleh pemerintah untuk meningkatkankemampuan peserta didik, salah satudiantaranya adalah merumuskan tujuan pendidikan. Pada konteks ini kita membahas tentang pembelajaran matematika maka tujuan dari pembelajaran matematika menurut Peraturan Menteri Pendidikan dan Kebudayaan Republik Indonesia Nomor 22 Tahun 2016 mengenai tujuan pembelajaran matematika, yakni (1) memahami konsep matematika, mendeskripsikan bagaimana keterkaitan antara konsep matematika dan menerapkan konsep secara efisien, luwes, akurat, dantepat dalam memecahkan masalah, (2) menalar pola sifat dari matematika, mengembangkan atau memanipulasi matematika dalam menyusun argumen, merumuskan bukti, atau mendeskripsikan argumen atau pernyataan matematika, (3) memecahkan masalah matematika yang meliputi kemampuan memahami masalah, menyusun model penyelesaian matematika, menyelesaikan model matematika, dan memberikan solusi yang tepat, dan (4) mengkomunikasikan argumen atau gagasan dalam bentuk tabel, diagram, simbol, ataupun media lainnya yang dapat memperjelas permasalahan ataupun keadaan. Tujuan dari pembelajaran matematika di 
Vol 2 No 2 Desember 2021

Jurnal AlphaEuclidEdu

Received: 02/03/2021; Resived: 23/09/2021; Accepted: 28/12/2021

atas sejalan dengan kemampuan literasi matematika yang sedang hangat diperbincangkan dalamkalangan pendidikan matematika internasional (Elviani, 2020).

Di dalam dunia pendidikan internasional peserta didik dituntut untuk dapat menyelesaikan persoalan matematika yang ada didalam kehidupan sehari-hari melalui kemampuan literasi matematika yang ada. Namun, kondisi pembelajaran matematika yang ada di Indonesia dapat dikatakan masih memiliki mutu pendidikan yang rendah jika dilihat dari kompetensi yang ada. Menurut berita Edukasi Kompas bahwa skor literasi yang ada di Indonesia berada di bawah literasi rata-rata skor PISA negara anggota OECD, yang mana skor rata rata ialah 489 sedangkan skor Indonesia 379 (Kompas.com, 2019). Hal ini menunjukan pentingnya literasi dalam menunjang pembelajaran matematika yang ada di sekolah (Panjaitan et al., 2021); (Fitriawan, 2021).

Secara umum literasi merupakan kemampuan dalam membaca, menulis, berbicara dan penggunaan bahasa. Literasi juga dapat dikaitkan dengan matematika. Literasi matematika merupakan kemampuan peserta didik untuk merumuskan, menerapkan dan menafsirkan matematika dalam bentuk konteks yang meliputi penalaran matematis dan penggunaan fakta, prinsip, konsep dan prosedural untuk mendeskripsikan suatu kejadian (OECD, 2016: 65); (Darmawati, 2020). Dalam literasi matematika terdapat berbagai macam literasi, salah satunya adalah literasi numerik atau dikenal juga literasi numerasi. Literasi numerasi adalah kemampuan seseorang dalam menggunakan angka dan simbol-simbol dalam matematika dalam bentuk kontekstual, menganalisis informasi dalam berbagai bentuk dan menginterpretasi serta mengkomunikasikan hasil analisis untuk mengambil kesimpulan (dalam Gerakan Literasi Nasional 2017: 3). Keterampilan literasi numerasi sangat di perlukan dalam kehidupan sehari-hari, dengan menggunakan angka dan simbol yang ada dikehidupan sehari-hari untuk menyelesaikan suatu permasalahan.

Literasi numerasi memiliki perbedaan dengan matematika, dimana pengetahuan matematika saja tidak membuat seseorang memiliki kemampuan literasi numerasi namun literasi numerasi mencakup keterampilan mengaplikasikan konsep matematika dalam bentuk kontekstual. Jadi jika seseorang memiliki kemampuan literasi baik maka keterampilan matematika baik pula namun sebaliknya jika kemampuan matematika baik belum tentu kemampuan literasi seseorang baik pula dikarenakan kemampuan literasi numerasi memerlukan tingkat berpikir yang cukup tinggi. Dari pengertian literasi numerasi sendiri dapat dilihat pembelajaran matematika memerlukan kemampuan berpikir yang cukup tinggi. Menurut hasil wawancara singkat peneliti dengan salah seorang guru matematika yang ada di SMA Panca Setya Sintang pada tanggal 29 Agustus 2020 melalui via whatsapp, permasalahan yangada di sekolah saat ini peserta didik masih sulit untuk menyelesaikan soal-soal kontekstual. Peserta didik mampu menyelesaikan permasalahan rutin atau soal-soal yang tidak berbentuk kontekstual. Salah satu contohnya pada materi persamaan dan pertidaksamaan nilai mutlak linear satu variable peserta didik sudah mampu mencari penyelesaian dari $|2 x-7|=3$, namun masih belum mampu menyelesaikan permasalahan kontekstual dari materi ini dan mengkomunikasikan kepada peserta didik lainnya. Selain itu faktor yang dapat mempengaruhi pembelajaran matematika ialah kecerdasan emosional seseorang, dimana kemampuan seseorang menguasai emosi dirinya dalam memahami permasalahan matematika dan cara seseorang berinteraksi dengan sesamanya dalam 
Vol 2 No 2 Desember 2021

Jurnal AlphaEuclidEdu

Received: 02/03/2021; Resived: 23/09/2021; Accepted: 28/12/2021

mengkomunkasikan permasalahan matematika yang ada.

Menurut Wardono dan Kurniasih (2015) salah satu upaya guru dalam meningkatkan kemampuan literasi matematika peserta didik adalah dengan melakukan inovasi pembelajaran, sehingga proses pembelajaran dapat meningkatkan kecerdasan emosional peserta didik. Menurut hasil observasi peneliti terhadapguru yang mengajar banyak peserta didik yang kurang percaya diri sehingga menjadi faktor penghambat dalam memahami materi yang disampaikan guru. Pada saat peserta didik mulai mendengarkan materi yang disampaikan oleh guru, ada peserta didik yang tidak memahami namun tidak punya kepercayaan diri untuk bertanya. Selain kurang percaya diri masalah yangdialami peserta didik ialah kurangnya motivasi dalam pembelajaran.

Pada saat mengerjakan soal banyak peserta didik yang mengalami kesulitan, namun tidak ada usaha untuk mengerjakan soal tersebut. Padahal jika peserta didik tersebut ada keinginan mengerjakan soal yang dianggap sulit itu akan dapat terselesaikan. Namun kebanyakan peserta didik menyerah terlebih dahulu dikarenakan tidak bisa menjawab. Terlebih pada kondisi sekarang, pembelajaran dilakukan secara daring dan kebanyakan guru mengalami kesulitan dalam mengajar dikarenakan kurangnya respon peserta didik dalam proses pembelajaran. Dapat dilihat pada saat pembelajaran daring peserta didik kurang memiliki kesadaran diri untuk mengikuti pembelajaran. Percaya diri, mudah menyerah dan kesadaran diri termasuk ke dalam kecerdasan emosional, yang mana kecerdasan emosional sangat berhubungan dengan literasi, jika seseorang memiliki kecerdasan emosional tinggi dapatmembantu seseorang tersebut dalammemahami soal matematika yang berkaitan dengan literasi numerasi.

Menurut Aunurrahman (2008: 69) kecerdasan emosional tidak kalah penting dengan kecerdasan akademik, kecerdasan emosional membuat seseorang mampu melihat masalah, mampu mengatasi kegagalan dan akan mencapai kesuksesan. Jadi dengan dimilikinya kecerdasan emosional yang baik dapat membantu seseorang mencapai kesuksesannya. Kemampuan literasi numerasi merupakan kemampuan berpikir matematika tingkat tinggi, namun pada kenyataannya kemampuan berpikir matematika peserta didik masih rendah. Menurut Goleman(dalam Prawira, 2011: 159) kesuksesan peserta didik didukung dari $20 \%$ kecerdasan akademik dan 80\% merupakan kecerdasan lain yang disebut kecerdasan emosional. Salovery and Mayer (dalam Prawira, 2011: 113) kecerdasan emosional yaitu kemampuan untuk mengenali diri sendiri secara tepat, kemampuan memotivasi diri, kemampuan mengenali emosi orang lain dan kemampuan menjalin hubungan dengan orang lain. Jadi jika peserta didik memiliki kecerdasan emosional yang baik maka peserta didik tersebut dapat menyelesaikan permasalahan matematika yang menuntut peserta didik memiliki kemampuan berpikir matematika tingkat tinggi. Atau dapat diperjelas jika peserta didik memiliki kecerdasan emosional baik maka kemampuan literasi peserta didik tersebut juga baik (Fitriawan, 2004).

\section{Metode Penelitian}

Metode yang digunakan dalam penelitian ini adalah metode deskriptif dengan bentuk penelitian studi kasus. Subjek dalam penelitian ini adalah peserta didik kelas X IPA 3 SMAS Panca Setya Sintang sebanyak 17 orang. Sedangkan objek dalam penelitian ini adalah literasi numerasi pada materi persamaan dan pertidaksamaan nilai mutlak linear satu variabel dikaji dari kecerdasan emosionl peserta didik. Teknik 
Vol 2 No 2 Desember 2021

Jurnal AlphaEuclidEdu

Received: 02/03/2021; Resived: 23/09/2021; Accepted: 28/12/2021

pengumpulan data dalam penelitian ini adalah teknik tes, angket dan wawancara. Prosedur penelitian dalam penelitian ini terdapat 3 tahap yaitu: tahap persiapan, tahap pelaksanaan dan tahapakhir.

Tahap Persiapan

Dalam tahapan persiapan, kegiatan yang dilakukan adalah (1) menyusun desain penelitian, (2) membuat instrumenpenelitian berupa angket kecerdasan emosional, kisikisi soal tes, soal tes literasi numerasi pada materi persamaan dan pertidaksamaan nilai mutlak, alternatif penyelesaian, pedoman indikator literasi numerasi, dan pedoman wawancara, (3) melakukan validasi instrument, (4) merevisi instrument berdasarkan hasil validasi, (5) membuat google classroom, (6) melakukan uji coba instrument penelitian menggunakan classroom, (7) menganalisis data hasil uji coba, (8) merevisi instrumen penelitian berdasarkan hasil uji coba

\section{Tahap Pelaksanaan}

Dalam tahap pelaksanaan dilakukan beberapa kegiatan yaitu: (1) membagikan link dan kode classroom kepada peserta didik, (2) memberikan angket kecerdasan emosional di google classroom kepada peserta didik, (3) memberikan soal tes literasi numerasi pada materi persamaan dan pertidaksamaan nilai mutlak linear satu variable di google classroom kepada peserta didik, (4) menganalisis hasil angket kecerdasan emosional, (5) mengelompokan peserta didik menurut tingkatan kecerdasan emosional peserta didik yaitu tinggi, sedangdan rendah, (6) menganalisis hasil tesliterasi numerasi, (7) melakukan wawancarakepada 3 orang peserta didik yang terdiri dari 1 orang peserta didik yang memiliki kecerdasan emosional tingkat tinggi, 1 orang peserta didik yang memiliki kecerdasan emosional tingkat sedang dan 1 orang peserta didik yang memiliki kecerdasan emosional tingkat rendah, (8) melakukan analisis terhadap hasil wawancara, (9) mendeskripsikan hasilpengolahan data, (10) menarik kesimpulan untuk menjawab permasalahan berdasarkan rumusan masalah.

\section{Tahap Akhir}

Dalam tahapan akhir kegiatan ini yang akan dilakukan adalah menyusun laporan penelitian.

\section{Hasil Penelitian dan Pembahasan \\ Hasil Penelitian \\ Angket Kecerdasan Emosional}

Salah satu instrumen dalam pengumpulan data yang digunakan adalah angket kecerdasan emosional. Angket kecerdasan emosional digunakan untuk mengetahui tingkatan kecerdasan emosional peserta didik. Angket diberikan kepada 17 peserta didik di kelas X IPA 3 SMAS Panca Setya Sintang. Hasil angket dapat dilihat pada tabel berikut.

Tabel 1. Jumlah Skor dan Kategori Kecerdasan Emosional Peserta Didik

\begin{tabular}{|c|c|c|c|}
\hline No & Nama & Skor & Kategori \\
\hline 1 & ATA & 61,3 & Sedang \\
\hline 2 & AF & 90,5 & Tinggi \\
\hline 3 & EDN & 82,5 & Tinggi \\
\hline 4 & YE & 61 & Sedang \\
\hline 5 & AP & 26,1 & Rendah \\
\hline
\end{tabular}


Vol 2 No 2 Desember 2021

Jurnal AlphaEuclidEdu

Received: 02/03/2021; Resived: 23/09/2021; Accepted: 28/12/2021

\begin{tabular}{|c|c|c|c|}
\hline 6 & SA & 54,5 & Sedang \\
\hline 7 & KM & 27 & Rendah \\
\hline 8 & PGE & 62,5 & Sedang \\
\hline 9 & RSH & 59,6 & Sedang \\
\hline 10 & AN & 68,2 & Sedang \\
\hline 11 & MOM & 66,8 & Sedang \\
\hline 12 & MW & 66,4 & Sedang \\
\hline 13 & SN & 57,4 & Sedang \\
\hline 14 & SM & 53,7 & Sedang \\
\hline 15 & U & 64,2 & Sedang \\
\hline 16 & HS & 81,6 & Tinggi \\
\hline 17 & FYNA & 80,4 & Tinggi \\
\hline
\end{tabular}

Berdasarkan tabel 1 dari 17 peserta didikdiperoleh 4 peserta didik yang memiliki tingkat kecerdasan emosional tinggi, 11 peserta didik dengan kecerdasan emosional tingkat sedang dan 2 peserta didik dengan kecerdasan emosonal tingkat rendah.

\section{Literasi Numerasi}

Selain angket kecerdasanemosional, tes literasi numerasi juga merupakan salah satu instrumen dalam pengumpulan data dalah penelitian ini. Tes berupa soal literasi dengan materi persamaan dan pertidaksamaan nilai mutlak linear satu variabel. Berikut merupakan hasil dari tes literasi numerasi dengan jumlah soal sebanyak 4 soal.

Tabel 2. Hasl Perolehan Skor Literasi Numerasi

\begin{tabular}{|c|c|c|c|c|c|c|}
\hline \multirow[t]{2}{*}{ No } & \multirow[t]{2}{*}{ Nama } & \multicolumn{4}{|c|}{$\begin{array}{c}\text { Skor } \begin{array}{c}\text { Literasi Numerasi } \\
\text { Per Soal }\end{array}\end{array}$} & \multirow[t]{2}{*}{ Jumlah } \\
\hline & & 1 & 2 & 3 & 4 & \\
\hline 1 & ATA & 2 & 4 & 2 & 1 & 7 \\
\hline 2 & $\mathrm{AF}$ & 6 & 6 & 6 & 6 & 24 \\
\hline 3 & EDN & 6 & 6 & 6 & 6 & 24 \\
\hline 4 & YE & 4 & 1 & 3 & 2 & 9 \\
\hline 5 & $\mathrm{AP}$ & 2 & 0 & 1 & 1 & 2 \\
\hline 6 & SA & 4 & 3 & 4 & 1 & 9 \\
\hline 7 & KM & 2 & 1 & 1 & 1 & 4 \\
\hline 8 & PGE & 5 & 2 & 2 & 1 & 8 \\
\hline 9 & RSH & 5 & 1 & 3 & 1 & 9 \\
\hline 10 & AN & 2 & 5 & 6 & 6 & 19 \\
\hline 11 & MOM & 4 & 4 & 4 & 4 & 16 \\
\hline 12 & MW & 4 & 1 & 2 & 1 & 7 \\
\hline 13 & SN & 4 & 3 & 1 & 1 & 6 \\
\hline 14 & SM & 5 & 5 & 2 & 1 & 13 \\
\hline 15 & $\mathrm{U}$ & 4 & 5 & 4 & 1 & 13 \\
\hline 16 & HS & 6 & 5 & 5 & 6 & 22 \\
\hline 17 & FYNA & 6 & 6 & 6 & 6 & 24 \\
\hline
\end{tabular}

Berdasarkan tabel 2 hasil perolehan skor literasi numerasi pada materi persamaan dan pertidaksamaan nilai mutlak linear satu variabel dapat dilihat bahwa 
Vol 2 No 2 Desember 2021

Jurnal AlphaEuclidEdu

Received: 02/03/2021; Resived: 23/09/2021; Accepted: 28/12/2021

29,4\% peserta didik memiliki literasi numerasi baik, 41,1\% peserta didik memiliki numerasi cukup baik dan 29,4\% peserta didik memiliki literasi numerasi kurang baik. Dari hasil pencapaian skor yang ada, ada 3 indikator yang dijadikan dasar penilaian literasi numerasi yaitu peserta didik mampu menggunakan berbagai macam angka dan simbol-simbol yang terkait dengan matematika dasar untuk memecahkan permasalahan kontekstual dan menganalisis informasi yang berbentuk grafik, tabel, bagan, dll serta menggunakan interpretasi dan mengkomunikasikan hasil analisis tersebut untuk memprediksi dan mengambil kesimpulan akhir. Berikut merupakan pencapaian indikator literasi numerasi pada peserta didik kelas X IPA 3. 
Vol 2 No 2 Desember 2021

Jurnal AlphaEuclidEdu

Received: 02/03/2021; Resived: 23/09/2021; Accepted: 28/12/2021

Tabel 3. Pencapaian Indikator Literasi Numerasi

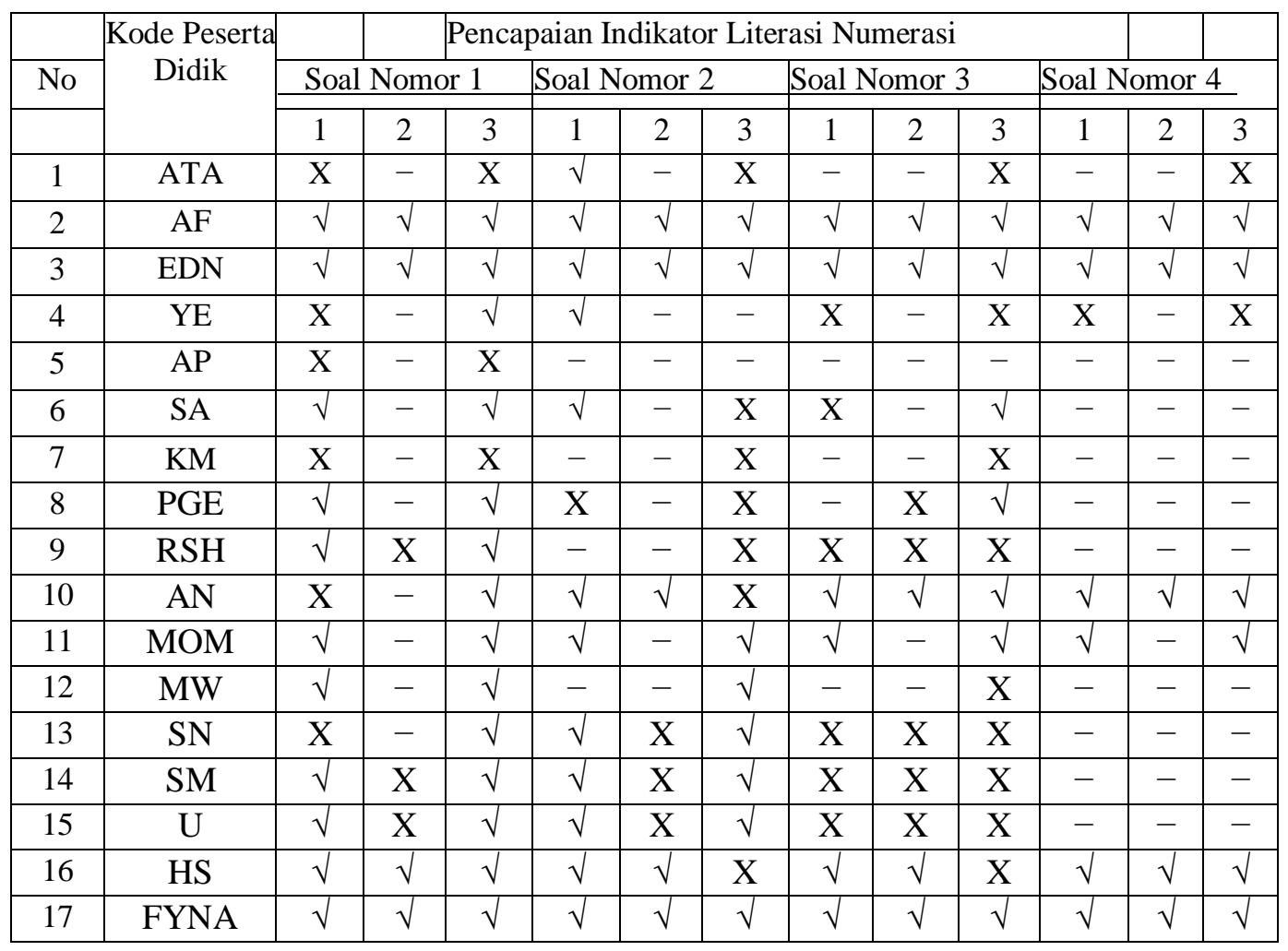

\section{Literasi Numerasi Dikaji Dari Kecerdasan Emosional Peserta didik}

a. Literasi Numerasi Peserta Didik Dengan Kecerdasan Emosional TingkatTinggi

Berdasarkan hasil tes literasi numerasi yang dilakukan terhadap 17 peserta didik, ada empat peserta didik yang memiliki kecerdasan emosional tingkat tinggi yaitu peserta didik dengan kode AF, EDN, HS dan FYNA. Dilihat dari hasil tes, peserta didik yang memiliki kecerdasan emosional tingkat tinggi juga memiliki literasi numerasi yang sangat baik. Seperti dari hasil tes AF, EDN dan FYNA yang mencapai maksimal dari skor tes yaitu 24. Ketiga peserta didik ini dapat menjawab tesdengan baik dan benar sesuai dengan indikator yang diujikan.

b. Literasi Numerasi Peserta Didik Dengan Kecerdasan Emosional TingkatSedang Berdasarkan hasil tes literasi numerasi yang diberikan kepada 17 peserta didik, ada 11 peserta didik dengan tingkat kecerdasan emosional sedang yaitu ATA, YE, SA, PGE, RSH, AN, MOM, MW, SN, SM, dan U. Dari kesebelas peserta didik ini memperoleh hasil tes yang bervariasi. Seperti halnya pada peserta didik dengan kode AN, iamemperoleh hasil tes yang bagus yaitu 19 untuk AN. Selain itu, terdapat juga peserta didik yang memperoleh hasil tes yang cukup seperti YE, SA, RSH, MOM, SM, dan U. Hasil tes literasidari keenam peserta didik ini, adasekitar empat peserta didik yang belum mampu mencapai indicator menganalisis informasi yang ditampilkan dalam berbagai bentuk yaitu MOM, YE, RSH, dan SM. Peserta didik yang memiliki tingkat kecerdasan emosional sedang juga ada yang memperoleh hasil tes literasi numerasi yang kurang baik yaitu MW, ATA, PGE dan SN dimana 
Vol 2 No 2 Desember 2021

Jurnal AlphaEuclidEdu

Received: 02/03/2021; Resived: 23/09/2021; Accepted: 28/12/2021

peserta didik ini belum mampu mencapai keseluruhan indikator yang ada.

c. Literasi Numerasi Peserta Didik dengan Kecerdasan Emosional Tingkat Rendah

Berdasarkan hasil tes literasi numerasi yang diberikan kepada 17 peserta didik, ada dua peserta didik yang memilikikecerdasan emosional tingkat rendah yaitu AP dan KM. Dari hasil pengerjaan soal tes literasi numerasi menunjukan bahwa peserta didik yang memiliki tingkat kecerdasan emosionalrendah secara keseluruhan hasil tes literasi numerasinya juga kurang baik.

\section{Pembahasan}

Kecerdasan emosional adalah kemampuan individu dalam mengenali perasaan diri sendiri dan perasaan orang lain, mampu memotivasi diri sendiri, mampu mengolah emosi dan dapat berhubungan sosial yang baik dengan sesamanya. Menurut Aunurrahman (2008: 69) kecerdasan emosional tidak kalah penting dengan kecerdasan akademik, kecerdasan emosional membuat seseorang mampu melihat masalah, mampu mengatasi kegagalan dan akan mencapai kesuksesan. Jadi dengan dimilikinya kecerdasan emosional yang baik dapat membantu seseorang mencapai kesuksesannya. Menurut Goleman (dalam Prawira, 2011: 159) kesuksesan peserta didik didukung dari $20 \%$ kecerdasan akademik dan 80\% merupakan kecerdasan lain yang disebut kecerdasan emosional. Dalam penelitian ini, kita akan melihat literasi numerasi peserta didik yang dikaji dari tingkatan kecerdasan emosional peserta didik tersebut. Literasi numerasi termasuk dalam literasi matematika, dimana literasi ini memerlukan kemampuan berpikir tingkat tinggi. Dilihat dari pendapat para ahli diatas mengennai kecerdasan emosional yang berpengaruh dalam kesuksesan belajar peserta didik, maka dapat disimpulkan juga jika peserta didik memiliki kecerdasan emosional yang baik maka peserta didik tersebut dapat menyelesaikan permasalahan matematika yang menuntut peserta didik memiliki kemampuan berpikir matematika tingkat tinggi. Atau dapat diperjelas jika peserta didik memiliki kecerdasan emosional baik maka kemampuan literasi pesertadidik tersebut juga baik.

Literasi numerasi pada materi persamaan dan pertidaksamaan nilai mutlak linear satu variabel pada peserta didik yang memiliki tingkat kecerdasan emosional rendah juga cendrung rendah. Peserta didik yang tergolong dalamkecerdasan emosional tingkat rendah ada dua orang yaitu AP dan KM. Hasil yang diperoleh dari kedua peserta didik itu adalah 2 untuk AP dan 4 untuk KM. Dilihat dari hasil maksimal tes literasi numerasi ialah 24 hasil yang diperoleh dari kedua peserta didik ini dapat dikatakan rendah. Dapat dilihat bahwa hasil penelitian sesuai dengan teori yang ada. Literasi numerasi pada peserta didik dengan tingkat kecerdasan emosional sedang sangat bervariasi dapat dilihat bahwa ada peserta didik yang memiliki literasi numerasi yang baik yaitu AN. Hasil yang diperoleh AN dapat digolongkan baik karena sebagian besar indikator dapat tercapai. Selain itu pada peserta didik lain ada enam orang yang memiliki literasi numerasi yang cukup baik, peserta didik ini sudah cukup mampu dalam mencapai indikator yang ada walaupun ada beberapa indikator yang masih belum tercapai. Kemudian empat orang diantara peserta didik yang memiliki kecerdasan emosional tingkat sedang memiliki literasi numerasi yang kurang baik, keempat peserta didik ini belum mampu mencapai sebagian besarindikator yang ada. Hasil penelitianpada tingkat kecerdasan emosionalsedang tidak sesuai dengan teori yang ada. Literasi numerasi pada peserta didik yang memiliki kecerdasan emosioanal tingkat tinggi memiliki literasi numerasi yang baik. Dilihat dari hasil tes dimana keempat peserta didik ini sudah 
Vol 2 No 2 Desember 2021

Jurnal AlphaEuclidEdu

Received: 02/03/2021; Resived: 23/09/2021; Accepted: 28/12/2021

mampu mencapai seluruhindikator yang ada, walaupun pada peserta didik HS terdapat kekeliruan sedikit pada salah satu indikator yang ada. Hal ini dapat dikatakan hasil penelitian sesuai dengan teori yang ada.

Dari Hasil dan pembahasan dalam penelitian ini dapat dilihat bahwa tidak selalu peserta didik yang memiliki kecerdasan emosional sedang juga memiliki literasi numerasi yang cukup baik. Dari hasil penelitian peserta didik dengan tingkat kecerdasan emosional sedang juga memiliki literasi yang baik dan kurang baik pula.

Pada kecerdasan emosional tingkat sedang memiliki literasi numerasi yang bervariasi. Pada teori yang ada, seharusnya kercerdasan emosional tingkat sedang memiliki literasi numerasi yang cukup baik. Namun, pada kenyataan dalam penelitian ini tidak sesuai dengan teori. Dilihat dari hasil tes literasi banyak peserta didik yang mengalami kesulitan dalam mengerjakannya. Didukung juga dalam wawancara dengan salah seorang peserta didik, ia mengatakan jika ia merasa kesulitan dalam mengerjakan pada soal nomor 4. Sehingga pada saat mengerjakan ada yang melihat google ataupun bertanya pada teman yang lain, karena tes dilakukan secara online. Selain itu, banyak peserta didik yang tidak teliti dalam mengerjakan soal- soal literasi numerasi. Dilihat dari hasil tes ada yang hanya menjawab sebagian saja dan terburu-buru dalam mengerjakan, karena pada saat tes ada waktu pengumpulan dan peserta didik banyak juga yang mengalami masalah dalam jaringan.

\section{Kesimpulan dan Saran Kesimpulan}

Berdasarkan hasil penelitian dan pembahasan pada bab IV, maka dapat disimpulkan bahwa: Kecerdasan emosional tingkat rendah pada dua orang peserta didik cenderung memiliki literasi numerasi kurang baik, dikarenakan dua peserta didik ini belum mampu mencapai dari ketiga indikator yang ada, yaitu belum mampu menggunakan berbagai macam angka dan simbol-simbol yang terkait dengan matematika dasar untuk memecahkan masalah kontekstual, menganalisis informasi yang ditampilkan dalam berbagai bentuk, dan menggunakan interpretasi dan mengkomunikasikan hasil analisis untukmemprediksi dan mengambilkesimpulan.

Kecerdasan emoisonal tingkat sedang pada sebelas orang peserta didik memiliki literasi numerasi yang bervariasi, yaitu satu orang dengan literasi numerasi yang baik, mampu mencapai dari ketiga indikator yang ada. Ada enam orang dengan literasi numerasi yang cukup baik, mampu mencapai beberapa indikator yang ada dalam literasi numerasi. Contohnya pada peserta didik dengan kode MOM, dimana peserta didik ini hanya mampu mencapai dua indikator saja yaitu mampu menggunakan berbagai macam angka dan simbol-simbol yang terkait dengan matematika dasar untuk memecahkan masalah kontekstual dan mampu menggunakan interpretasi dan mengkomunikasikan hasil analisis untukmemprediksi dan mengambilkesimpulan.

Empat orang dengan literasi numerasi yang kurang baik, dimana subjek belum mampu mencapai seluruh indikator yang ada. Jadi tidak semua peserta didik yang tergolongdalam kecerdasan emosional tingkat sedang memiliki literasi yang cukup baik. Kecerdasan emosional tingkat tinggi pada empat orang peserta didik cenderung memiliki literasi numerasi yang baik, yaitu mampu mencapai seluruh indikator yang dimaksud.

\section{Saran}

Beberapa saran yang dapat penulis sampaikan berdasarkan hasil temuan dalam 
Vol 2 No 2 Desember 2021

Jurnal AlphaEuclidEdu

Received: 02/03/2021; Resived: 23/09/2021; Accepted: 28/12/2021

penelitian ini yaitu: a) Hasil penelitian ini menunjukan bahwa kecerdasan emosional subjek penelitian tergolong sedang atau dapat dikatakan sudah baik. Oleh karena itu kepada pengajar di SMAS Panca Setya Sintang, orang tua dan orang-orang yang berkewajiban agar dapat mempertahankan terus pola-pola bimbingan dan penghargaannya selama ini, sambil tersu menambah informasi yang berkaitan dengan kecerdasan emosional, sehingga diharapkan akan lebih efektif dalam membantu pengembangan diri peserta didik; b) Hasil penelitian ini menunjukan bahwa literasi numerasi subjek penelitian tergolong sedang. Dengan demikiandiharapkan kepada guru untukmempertahankan pengajaran didalamkelas, sambil meningkatkan literasi numerasi peserta didik dengan latihan- latihan soal kontekstual yang diharapkan mampu membantu peserta didik meningkatkan literasi numerasi.

\section{Referensi}

Aunurrahman. 2008. Belajar danPembelajaran. Bandung: Alfabeta.

Darmawati. (2020). Matematika Dengan Metode Tutor Sebaya. 1(2), 49-58.

Elviani, D. (2020). Vol 1, No 1: 2020. Jurnal AlphaEuclidEdu, 1(1), 1-8. https://doi.org/10.21428/8c841009.086f1532

Fitriawan, D. (2004). Strategi Reorientasi Kurikulum Pendidikan Matematika Di Era Revolusi Industri 4.0. Jurnal Pengabdi, 4, 300.

Fitriawan, D. (2021). Ekplorasi Bahan Ajar Geometri Dalam Kesinambungan Diskursus Matematika. Jurnal Derivat: Jurnal Matematika Dan Pendidikan Matematika, 8(1), 11-20. https://doi.org/10.31316/j.derivat.v8i1.1332.

Kemendikbud. 2017. Gerakan Literasi Nasional. Jakarta: Kemendikbud. Online. Diakses 1 September 2020.

Kurniasih, A.W. \& Wardono. 2015. Peningkatan Literasi Matematika Mahasiswa Melalui Pembelajaran Inovatif Realistik E-learning Edmodo Bermuatan Karakter Cerdas Kreatif Mandiri. Jurnal Matematika Kreatif- Inovatif.6(1) : 93 - 100 OECD. (2016). PISA 2015 Results in Focus. New York: Columbia University.

Panjaitan, S., Hartoyo, A., \& Fitriawan, D. (2021). Eksplorasi Etnomatematika Kain Tenun Songket Suku Melayu Sambas. Jurnal AlphaEuclidEdu, 2(1), 19-31. https://jurnal.untan.ac.id/index.php/AlphaEuclidEdu/article/view/47890

Prawira, Purwa Atmaja. 2011. Psikologi Pendidikan dalam Perspektif Baru. Jogjakarta: Ar Ruzz Media. 
Vol 2 No 2 Desember 2021

Jurnal AlphaEuclidEdu

Received: 05/10/2021; Resived: 11/11/2021; Accepted: 29/12/2021

\title{
PENGEMBANGAN BLOG PEMBELAJARAN MATEMATIKA MATERI PECAHAN DI SEKOLAH MENENGAH PERTAMA
}

\author{
Ignasius Layola Dedy, Dede Suratman, Munaldus \\ Program Studi Pendidikan Matematika FKIP Untan Pontianak \\ Email: dedydisel@gmail.com
}

\begin{abstract}
This study aims to develop a product for developing a mathematics learning blog on material in junior high school. The research method used in this research is the research and development method. Research and development are the process of developing a new product or improving an existing product. The data collection tools include a material expert validation questionnaire, a media expert validation questionnaire, and a student response questionnaire. From the results of material expert validation, an average score of 75 was obtained with a good category, the results of media expert validation obtained an average score of 75 with a good category, then the response questionnaire was obtained, namely a positive response with a percentage of $96.18 \%$ and a negative response with a percentage of $3.82 \%$. Based on the data obtained, it can be obtained that the blog development product is as expected and in accordance with the needs and curriculum. The responses that have been submitted to students get a very good response.
\end{abstract}

Keywords: Blog development, fractions, junior high school

\section{Pendahuluan}

Pada saat ini, semua negara yang ada di dunia tengah menghadapi pandemik Covid-19. Seluruh kegiatan dibatasi demi menunda tersebarnya virus Corona, termasuk kegiatan pendidikan. Di Indonesia sendiri, seluruh kegiatan pendidikan dimulai dari tingkatan dasar serta menengah hingga tingkatan perguruan tinggi dilaksanakan dengan daring (dalam jaringan) tidak dengan bertemu wajah diantara guru dan pelajara secara langsung.

Perkembangan serta peralihan ilmu pengetahuan setra teknologi akan maju sekarang ini, meningkatkan pemanfaatan teknologi dalam proses belajar. Guru diharapkan mampu menggunakan dan mengembangakan ketrampilan dalam membuat media pembelajaran berbasis teknologi maju (Azhar Arsyad, 2009: 2); (Andiani \& Fitria, 2021).

Berdasarkan pengamatan peneliti terhadap siswa saat jam pelajaran matematika materi pecahan yang berlangsung secara daring dengan media WhatsApp, siswa terlihat kurang aktif dengan materi yang diberikan ditambah dengan perolehan tanya jawab peneliti bersama pendidik bidang studi matematika yang ada pada SMP Islamiyah Pontianak kemampuan siswa dalam materi pecahan masih tergolong rendah, dibuktikan dengan hasil ulangan harian dimana hanya 30\% siswa yang memenuhi KKM dari 27 orang siswa.

Berkenaan dengan gejala-gejala di atas, maka pembelajaran matematika harus menarik dan menyenangkan siswa. Salah satunya penggunaan media pembelajaran melalui internet yaitu blog pembelajaran matematika yang dapat di akses dengan gratis. Berkaitan atas pemikiran meciptakan keadaan akan kondusif, media menjadi sebagian pengaruh yang turut memastikan keberhasilan belajar mengajar. Kata media bermula sejak bahasa latin yakni medium bahwa secara harfiah mengandung tengah penghubung atau pendahuluan. Beserta kata berbeda media merupakan penghubung atau pendahulu 
Vol 2 No 2 Desember 2021

Jurnal AlphaEuclidEdu

Received: 05/10/2021; Resived: 11/11/2021; Accepted: 29/12/2021

pesan (Sutikno, 2009: 105); (Rizal \& Walidain, 2019).

Penggunaan media Blog pembelajaran matematika berarti menjadikan pembelajaran akan bertambah menggirangkan atau menyenangkan.Karena dengan memanfaatkan Blog pembelajaran matematika siswa dapat berinternet sembari belajar. Pembelajaran akan menggirangkan adalah pembelajaran akan keadaan belajar mengajar adapun menciptakan siswa girang berakibat siswa terpusat pandangan dengan lengkap serta waktu tercurah perhatianya (time on taks) terpusat. Terpusatnya time on taks menjadi meningkatnya perolehan belajar siswa.

Blog pembelajaran matematika merupakan kependekan melalui web log. Blog pembelajaran matematika ialah program web bahwa pada dalamnya mengandung informasi berbentuk tulisan mengenai materi pembelajaran matematika yang dikenal dengan istilah posting (Fany Ariasari, 2006: 2-3); (Raisa et al., 2018).

Penelitian Prasetya (dalam Anggraeni, 2010) mengungkapkan tentang banyaknya persentase pembelajaran adapun memperoleh ketuntasan bahasa (nilai minimum 70) sesudah memakai sarana berbasis computer hasil pengembangan, sejumlah $83,37 \%$ serta tergolong kriteria adapun sangat baik. Pembelajaran dengan Blog pembelajaran matematika yakni diinginkan untuk berhasil mendorong siswa agar berusaha untuk meningkatkan hasil belajar karena bisa diakses kapan juga serta dimana juga mampu menyampaikan materi secara menarik.

Berdasarkan hasil pengamatan dan sejalan dengan pandemi yang sedangan dialami masyarakat khusunya pelajar, Maka peneliti mencoba melakukan Pengembangan Blog Pembelajaran Matematika Pada Materi Pecahan di Sekolah Menengah Pertama.

\section{Metode Penelitian}

Metode penelitian dan pengembangan (Research and Development) suatu rangkaian maupun proses dengan tujuan mengembangkan produk baru atau memperbaiki produk yang sudah ada. maksud produk pada konteks ini yaitu tidak selalu berwujud hardware (modul,buku dan bahan bantu belajar di kelas), tetapi dapat juga berbentuk perangkat lunak (software) layaknya program dalam mengelola data, proses belajaran di kelas, laboratorium atau perpustakaan, atau pun pola pendidikan, pelatihan pembelajaran, penilaian, bimbingan, manajemen dan lainya. Objek yang diteliti ialah pengembangan blog pembelajaran matematika pada materi pecahan di SMP.

Penelitian terdiri atas tiga tahap yaitu: Tahapan pendahuluan, penelitian serta mengumpulkan informasi akan diproses melewati aktivitas analisis keperluan, survei pustakaan serta penelitian pada skala kecil. Salanjutnya perencangan, dalakukan indentifikasi kemampun-kempuan akan dibutuhkan pada kegiatan penelitian, membentuk rumusan tujuan yang ingin diperoleh, menciptakan desain serta rancanagan penelitian dan membuat harapan percobaan pada daerah terbatas.

Tahapan mengembangkan model, dilaksanakan rancangan berikut: Mengembangkan produk awal, menyiapkan bahan ajar proses pembelajaran dan instrument validasi. Memvalidasi produk blog pembelajaran kepada kelompok ahli yaitu ahli materi dan ahli media. Revisi blog, yaitu dilaksanakan revisi pada blog awal yang sudah diproses didasarkan oleh penemuan serta saran pada validasi kepada ahli media serta ahli materi. Pengujian terbatas, dilakukan dengan mengujicoba blog yang sudah divalidasi serta dikatakan pantas oleh ahli materi dan ahli media.

Tahap pengujian model, Saat pengujicoba terbatas dilaksanakan observasi, peluasan angket respon siswa, untuk keinginan memperoleh evaluasi kulitatif blog akan 
Vol 2 No 2 Desember 2021

Jurnal AlphaEuclidEdu

Received: 05/10/2021; Resived: 11/11/2021; Accepted: 29/12/2021

dikembangkan. Selain itu juga dilaksanakan pengambilan data kualitatif mengenai proses saat produk yang dikembanagkan dilakukan. rancangan setelah revisi blog dilandaskan pada uji coba terbatas, dilaksanakan revisi blog hingga memperoleh produk akhir /model akhir.

\section{Hasil Penelitian dan Pembahasan Hasil Penelitian}

Hasil penelitian serta bahasan dalam penelitian ini didapat melalui beberapa tahap, yaitu melalui validasi ahli media dan validasi ahli materi. Dimana validasi dari ahli media serta ahli materi untuk melihat kesesuaian Blog hasil pengembangan Pembelajaran matematika pada materi pecahan di SMP ditinjau pada aspek materi ataupun isi, aspek pembelajaran, aspek tampilan seta aspek pemograman. Selain itu hasil penelitian juga diperoleh dari angket respon siswa, dimana angket tersebut dapat melihat tanggapan siswa pada Blog hasil pengembangan Pembelajaran Matematika pada materi pecahan di sekolah menengah pertama.

Validasi akan dilaksanakan dari ahli materi terdiri dari dua apek, yaitu aspek isi/materi serta aspek pembelajaran. yang bisa diperhatikan tabel di bawah

Tabel 1. Hasil Validasi Aspek Isi / Materi

\begin{tabular}{|c|l|c|c|c|c|c|}
\hline \multirow{2}{*}{ No } & \multicolumn{1}{|c|}{ Aspek Penilaian } & \multicolumn{3}{|c|}{ Skor } & Keterangan \\
\cline { 2 - 5 } 1 & $\mathbf{1}$ & $\mathbf{2}$ & $\mathbf{3}$ & $\mathbf{4}$ & \\
Kesesuaian konsep materi dengan & & & $\sqrt{ }$ & & \\
\hline 2 & $\begin{array}{l}\text { Keruntum 2013 revisi. } \\
\text { pembelajaran materi yang ada dalam blog }\end{array}$ & & $\sqrt{ }$ & \\
\hline 3 & $\begin{array}{l}\text { Ketepatan contoh-contoh untuk } \\
\text { mempelajari isi / materi. }\end{array}$ & & $\sqrt{ }$ & \\
\hline 4 & $\begin{array}{l}\text { Ketepatan pemakaian bahasa selaras pada } \\
\text { tingkat pemahaman siswa SMP. }\end{array}$ & & $\sqrt{ }$ & \\
\hline 5 & $\begin{array}{l}\text { Kesesuaian gambar akan menjelaskan isi / } \\
\text { materi. }\end{array}$ & & $\sqrt{ }$ & \\
\hline 6 & $\begin{array}{l}\text { Keterikatan materi pada latihan atau } \\
\text { penilaian akhir. }\end{array}$ & & $\sqrt{ }$ & \\
\hline \multicolumn{2}{|c|}{ Jumlah Skor } & & & 18 & \\
\hline \multicolumn{2}{|l|}{ Rata-rata Skor } & & 75 & \\
\hline
\end{tabular}

Tabel 2. Validasi Aspek Pembelajaran

\begin{tabular}{|c|l|c|c|c|c|c|}
\hline \multirow{2}{*}{ No } & \multicolumn{2}{|c|}{ Aspek Penilaian } & \multicolumn{3}{|c|}{ Skor } & \multirow{2}{*}{ Keterangan } \\
\hline & & $\mathbf{1}$ & $\mathbf{2}$ & $\mathbf{3}$ & $\mathbf{4}$ & \\
\hline 1 & $\begin{array}{l}\text { Konsistensi antara KI, KD dengan } \\
\text { materi sajian yang ada dalam blog } \\
\text { pembelajaran matematika. }\end{array}$ & & & & $\sqrt{ }$ & \\
\hline 2 & $\begin{array}{l}\text { Penampilan teks akan } \\
\text { memperjelas materi. }\end{array}$ & & & $\sqrt{ }$ & & \\
\hline 3 & $\begin{array}{l}\text { Penampilan gambar saat } \\
\text { menperjelaskan materi. }\end{array}$ & & & $\sqrt{ }$ & & \\
\hline 4 & $\begin{array}{l}\text { Sistematika dalam penyajian } \\
\text { materi. }\end{array}$ & & & $\sqrt{ }$ & \\
\hline 5 & Kejelasan petunjuk belajar. & & & $\sqrt{ }$ & & \\
\hline 6 & Kemudahan dalam memahami & & & $\sqrt{ }$ & & \\
\hline
\end{tabular}


Vol 2 No 2 Desember 2021

Jurnal AlphaEuclidEdu

Received: 05/10/2021; Resived: 11/11/2021; Accepted: 29/12/2021

\begin{tabular}{|c|l|c|c|c|c|c|}
\hline & $\begin{array}{l}\text { materi yang ada dalam blog } \\
\text { pembelajaran matematika }\end{array}$ & & & & & \\
\hline 7 & $\begin{array}{l}\text { Keseimbangan materi dengan soal } \\
\text { contoh. }\end{array}$ & & & $\sqrt{ }$ & & \\
\hline 8 & $\begin{array}{l}\text { Diberikan penegasan pada hasil } \\
\text { soal dan latihan. }\end{array}$ & & & $\sqrt{ }$ & & \\
\hline 9 & $\begin{array}{l}\text { Pemberian ulasan pada hasil soal } \\
\text { yang salah }\end{array}$ & & $\sqrt{ }$ & & & \\
\hline Jumlah Skor & & & 27 & & \\
\hline Rata-rata Skor & & & 75 & & \\
\hline & & & & & \\
\hline
\end{tabular}

Pada tahap validasi ahli media, produk yang dihasilkan divalidasi dengan melihat dari aspek tampilan dan aspek pemograman.

Tabel 3. Validasi Aspek Tampilan

\begin{tabular}{|c|l|c|c|c|c|c|}
\hline \multirow{2}{*}{ No } & \multirow{2}{*}{ Aspek Penilaian } & \multicolumn{4}{|c|}{ Skor } & \multirow{2}{*}{ Keterangan } \\
\hline & & $\mathbf{1}$ & $\mathbf{2}$ & $\mathbf{3}$ & $\mathbf{4}$ & \\
\hline 1 & Pemilihan macam (font) / huruf & & & $\sqrt{ }$ & & \\
\hline 2 & Ukuran font / huruf & & & $\sqrt{ }$ & & \\
\hline 3 & Pengaturan alinea, jarak dan baris & & & $\sqrt{ }$ & & \\
\hline 4 & Kejelasan teks & & & $\sqrt{ }$ & & \\
\hline 5 & Kecocokan background dan tulisan & & & $\sqrt{ }$ & & \\
\hline 6 & Letak dan penampilan gambar & & & $\sqrt{ }$ & & \\
\hline 7 & $\begin{array}{l}\text { Keserasian warna tulisan dan } \\
\text { background / komposisi }\end{array}$ & & & $\sqrt{ }$ & & \\
\hline \multicolumn{2}{|l|}{ Jumlah Skor } & & & $\mathbf{2 1}$ & & \\
\hline \multicolumn{2}{|l|}{ Rata-rata skor } & & & $\mathbf{7 5}$ & & \\
\hline
\end{tabular}

Tabel 4. Validasi Aspek Pemograman

\begin{tabular}{|c|c|c|c|c|c|c|}
\hline \multirow{2}{*}{ No } & \multirow{2}{*}{ Aspek Penilaian } & \multicolumn{4}{|c|}{ Skor } & \multirow{2}{*}{ Keterangan } \\
\hline & & 1 & 2 & 3 & 4 & \\
\hline 1 & $\begin{array}{l}\text { Tingat interaktivitas siswa dengan } \\
\text { blog pembelajaran matematika. }\end{array}$ & & & $\sqrt{ }$ & & \\
\hline 2 & $\begin{array}{l}\text { Kemudahan dalam menggunakan } \\
\text { blog pmbelajaran matematika. }\end{array}$ & & & $\sqrt{ }$ & & \\
\hline 3 & Efisiensi teks & & & $\sqrt{ }$ & & \\
\hline 4 & Peletakan gambar & & & $\sqrt{ }$ & & \\
\hline & Jumlah Skor & & & 12 & & \\
\hline & Rata-rata Skor & & & 75 & & \\
\hline
\end{tabular}

Produk yang sudah divalidasi serta dilakukan revisi menurut masukan (komentar) dari ahli materi dan ahli media. Selanjutnya dilaksanakan ujicoba terbatas agar ditinjau pada aspek isi/materi dari perolehan respon siswa bisa diperhatikan tabel di bawah.

Tabel 5. Hasil Respon Siswa

\begin{tabular}{|c|c|c|c|c|c|}
\hline \multirow{2}{*}{ No } & \multirow{2}{*}{ Pertanyaan Angket Respon } & \multicolumn{2}{|c|}{ Hasil Respon } & \multicolumn{2}{c|}{ Persentase } \\
\cline { 3 - 6 } & & Positif & Negatif & Positif & Negatif \\
\hline 1 & $\begin{array}{l}\text { Bagaimana menurut anda tentang } \\
\text { pembelajaran matematika menggunakan }\end{array}$ & 21 & - & $100 \%$ & - \\
\hline
\end{tabular}


Vol 2 No 2 Desember 2021

Jurnal AlphaEuclidEdu

Received: 05/10/2021; Resived: 11/11/2021; Accepted: 29/12/2021

\begin{tabular}{|c|l|c|c|c|c|}
\hline & Blog? & & & & \\
\hline 2 & $\begin{array}{l}\text { Apakah tulisan yang terdapat pada blog } \\
\text { pembelajaran matematika tersebut sudah } \\
\text { jelas? Kalau sudah berikan komentar dan } \\
\text { kalau belum jelas beri komentar! }\end{array}$ & 20 & 1 & $95,23 \%$ & $4,77 \%$ \\
\hline 3 & $\begin{array}{l}\text { Menurut anda apakah materi yang } \\
\text { terdapat pada blog pembelajaran } \\
\text { matematika tersebut sudah jelas dan } \\
\text { mudah untuk dipahami? Jelaskan! }\end{array}$ & 21 & - & $100 \%$ & - \\
\hline 4 & $\begin{array}{l}\text { Bagaimana menurut anda tentang } \\
\text { tampilan pada blog pembelajaran } \\
\text { matematika tersebut, apakah sudah } \\
\text { menarik? Coba jelaskan! }\end{array}$ & 18 & 3 & $85,71 \%$ & $14,29 \%$ \\
\hline 5 & $\begin{array}{l}\text { Bagaimana menurut anda kemudahan } \\
\text { dalam penggunaan blog pembelajaran } \\
\text { tersebut? Jelaskan! }\end{array}$ & 21 & - & $100 \%$ & \\
\hline & \multicolumn{1}{|c|}{ Rata-Rata } & 96,19 & 3,81 & $96,18 \%$ & $3,82 \%$ \\
\hline
\end{tabular}

\section{Pembahasan}

Berdasarkan paparan hasil penelitian, Pertama hasil validasi dari ahli materi, pada validasi aspek isi atau materi. Ahli materi memvalidasi dengan memberikan centang di skor 3 kepada setiap aspek penilaian dengan rata-rata skor 75 ini dapat dikatagorikan baik, pada aspek penilaian nomor 1 sesesuaian konsep materi dengan kurikulum 2013 revisi sudah sesuai, aspek penilaian nomor 2 keruntunan materi yang ada dalam blog pembelajaran matematika sudah berurut, aspek penilaian nomor 3 ketepatan contohcontoh untuk memperjelas isi/materi sudah cukup, aspek penilaian nomor 4 keakuratan pemakaian bahasa sudah sesuai pada golongan pemahasan siswa SMP sudah tepat, aspek penilaian nomor 5 kesesuaian gambar untuk memperjelas isi/materi sudah sesuai dan aspek penilaian nomor 6 keterkaitan materi dengan latihan sudah sesuai.

Pada validasi aspek pembelajaran ahli materi memberikan centang pada skor 4 aspek penilaian nomor 1 ini dikarenakan blog yang di produksi sudah sesuai dan konsisten anatara KI, KD dengan materi yang di sajikan pada blog pembelajaran matematika. Pada aspek penilaian nomor 2 penyajian teks untuk memperjelas materi diberi skor 3 karena teks yang disajikan sudah jelas, aspek penilaian nomor 3 penyajian gambar untuk memperjelas materi diberi skor 3 karena gambar sudah jelas, aspek penilaian nomor 4 sistematika penyajian materi debikan skor 3 karena penyajian materinya sudah sistematis, aspek penilaian nomor 5 kejelasan petunjuk belajar diberikan skor 3 karena petunjuk belajar yang diberikan sudah jelas, aspek penilaian nomor 6 kemudahan dalam memahami materi yang ada dalam blog pembelajaran matematika diberikan skor 3 karena materi yang ada dalam blog sudah sesuai dengan bahasa siswa SMP, aspek penilaian nomor 7 keseimbangan materi dengan contoh soal diberikan skor 3 karena materi dan contoh soal sudah sesuai, aspek penilaian nomor 8 pemberian penguat untuk jawaban soal dan latihan diberikan skor 3 karena soal dan contoh soal cukup mudah untuk dipahami dan aspek penilaian nomor 9 pemberian balikan jawan soal yang salah diberikan skor 2 karena pemberian untuk jawaban yang salah masih kurang sesuai sehingga di sarankan diperbaiki lagi agar menjadi sesuai. Sehingga jumlah skor pada aspek pembelajaran yaitu 27 dengan rata-rata skor 75 yang dikatagorikan baik. Rata-rata aspek isi/materi ditambah dengan aspek pembelajaran memperoleh rata-rata 75 dan dinyatakan oleh ahli materi pantas agar diujicoba serta 
Vol 2 No 2 Desember 2021

Jurnal AlphaEuclidEdu

Received: 05/10/2021; Resived: 11/11/2021; Accepted: 29/12/2021

revisi berdasarkan saran.

Kedua hasil validasi ahli media, Pada validasi aspek tampilan ahli media memvalidasi dengan memberikan centang di skor 3 kepada setiap aspek penilaian dengan jumlah skor 21 dan rata-rata skor 75 ini dikatagorikan baik, pada aspek penilaian nomor 1 pemilihan jenis font atau huruf diberikan skor 3 karena jenis font atau huruf yang digunakan mudah untuk dibaca, aspek penilaian nomor 2 ukuran font atau huruf diberikan skor 3 karena ukuran font atau huruf yang digunakan sudah sesuai satu sama lain, aspek penilaian nomor 3 pengaturan jarak, baris, dan alinea diberikan skor 3 karena sudah sesuai dengan satu sama lain, aspek penilaian nomor 4 keterbacaan / kejelasan teks diberikan skor 3 karena teks pada blog sudah jelas, aspek penilaian nomor 5 keserasian backgraund dan tulisan diberikan skor 3 karena dianggap sudah serasi, aspek penilaian nomor 6 penempatan dan penampilan gambar diberikan skor 3 karena letah gambar sudah sesuai dan aspek penilaian nomor 7 keserasian warna tulisan dan backgraund / kompisisi diberikan skor 3 karena sudah serasi satu sama lainnya.

Pada validasi aspek pemograman ahli media juga memberikan centang di skor 3 pada setiap aspek penilaian. Aspek penilaian nomor 1 tingkat interakaktivitas siswa dengan blog pembelajaran matematika diberikan skor 3 karena interaktivitas blog dengan siswa baik ini di ukur dari jumlah kujungan ke blog pembelajaran matematika, aspek penilaian nomor 2 kemudahan dalam menggunakan blog pembelajaran matematika diberikan skor 3 karena blog yang digunakan belajar mudah digunakan cukup mengklik link yang dibagikan, aspek penilaian nomor 3 efisiensi teks diberika skor 3 karena teks yang ada dalam blog tidak berlebihan dalam menjelaskan materi atau contoh soal dan aspek penilaian nomor 4 peletakan gambar diberikan skor 3 karena gambar yang ada dalam blog pembelajaran sudah sesuai letaknya. Sehingga jumlah skor pada aspek pemograman yaitu 12 dengan rata-rata skor 75 yang dikatagorikan baik. Rata-rata aspek tampilan ditambah dengan aspek pemograman memperoleh rata-rata 75 dan dinyatakan oleh ahli media pantas agar diujicoba serta revisi berdasarkan saran.

Ketiga hasil respon siswa, Pada tahap ini respon siswa terhadap blog hasil pengembangan pembelajaran matematika pada materi pecahan di sekolah menengah pertama di tinjau dari aspek isi/materi. Respon yang diberikan siswa dari pengisisan angket terbuka di kelompokan terbagi dua yakni respon yang positif dan respon yang negatif. Respon yang positif; pertanyaan yang pertama dengan persentase $100 \%$ dari 21 responden memberikan respon sangat baik. Secara umum respon yang diberikan dari jawaban responden adalah "menyenangkan, sangat membantu, menarik". Respon pertanyaan yang kedua dengan persentase 95,23\% dari 21 responden. Adapun respon yang diberikan secara umum yaitu "sudah jelas, dapat dimengerti, penjelasannya mudah di pahami". Respon pertanyaan yang ketiga dengan persentase $100 \%$ dari 21 responden. Adapun respon yang diberikan secara umum yaitu "sudah jelas dan mudah di pahami karna disertai contoh". Respon pertanyaan yang keempat dengan persentase $85,71 \%$ dari 21 responden. Adapun respon yang diberikan secara umum yaitu "Menarik karena terdapat gambar". Respon pertanyaan yang kelima dengan persentase 100\% dari 21 responden. Adapun respon yang diberikan secara umum yaitu "Memudahkan dalam belajar karena bisa diakses kapan saja, tidak perlu bawa-bawa buku yang berat lagi". Respon Negatif.

Respon pertanyaan pertama bagaimana munurut anda tentang pembelajaran matematika menggunakan blog? Hasil respon siswa tidak ada yang negatif semuanya menyatakan "menyenangkan, sangat membantu, menarik" sehingga persentasenya $0 \%$. Respon tentang kedua apakah tulisan yang terdapat pada blog pembelajaran matematika 
Vol 2 No 2 Desember 2021

Jurnal AlphaEuclidEdu

Received: 05/10/2021; Resived: 11/11/2021; Accepted: 29/12/2021

tersebut sudah jelas? Dengan persentase $4,77 \%$ dari 21 responden. Adapun respon yang diberikan secara umum yaitu "ada beberapa yang belum jelas, beberapa angka tidak bisa dilihat karena dalam bentuk kode". Respon pertanyaan ketiga menurut anda apakah materi yang terdapat pada blog pembelajaran matematika tersebut sudah jelas dan mudah untuk dipahami? Jelaskan! Hasil respon siswa tidak ada yang negatif semuanya menyatakan "sudah jelas". Respon pertanyaan keempat tentang tampilan pada blog pembelajaran matematika dengan persentase 14,29\% dari 21 responden. Adapun respon yang diberikan secara umum yaitu "gambarnya masih kurang, tulisannya masih sedikit berdempetan". Respon pertanyaan kelima bagaimana menurut anda kemudahan dalam penggunaan blog pembelajaran tersebut? Jelaskan dengan persentase $0 \%$ dari 21 responden. Secara umum menjawab "Memudahkan dalam belajar karena bisa diakses kapan saja, tidak perlu bawa-bawa buku yang berat lagi". Hasil respon siswa dari 21 orang yang menjawab menyatakan respon positif sebesar 96,19 dengan persentase 96,18\% sedangkan yang memberikan respon negatif sebesar 3,81 dengan persentase $3,82 \%$.

\section{Simpulan dan Saran Simpulan}

Berdasarkan temuan penelitian pada pengembangan Blog pembelajaran matematika pada materi pecahan di sekolah menengah pertama "Belajar Matematika Kuy" peneliti menyajikan materi operasi pecahan yang dilengkapi dengan gambar serta contoh soal yang mudah dipahami dan digunakan untuk memperjelas materi operasi pecahan, dapat disimpulkan bahwa: (1)Kesesuaian Blog hasil pengembangan pembelajaran matematika pada materi pecahan di sekolah menengah pertama di tinjau pada aspek isi/materi serta aspek pembelajaran dengan nilai rata-rata sebesar 75 . Sedangkan aspek tampilan serta aspek pemograman pada nilai rata-rata yaitu 75 . pada skor rata-rata yang telah didapat telah selaras pada yang diinginkan serta selaras pada kebutuhan dan kurikulum. (2) Tanggapan siswa terhadap blog hasil pengembangan pembelajaran matematika pada materi pecahan di sekolah menengah pertama mendapatkan respon yang sangat baik, walaupun ada sedikit kesalahan dan kekurangan pada Blog pembelajaran matematika. Tanggapan yang telah disampaikan siswa merupakan masukan bagi pengembangan Blog pembelajaran matematika ini agar lebih baik lagi dan mengembangkan sesuai dengan kebutuhan siswa di sekolah.

\section{Saran}

Bagi peneliti berikutnya yang akan mengembangkan Blog pembelajaran matematika pada materi pecahan di sekolah menengah pertama disarankan: (1) Untuk lebih mengerti mengenai bahasa pemograman Latex sehingga tidak kesusahan dalam menulis simbol-simbol dalam pembelajaran matematika; (2) Untuk peneliti selanjutnya yang akan mengembangkan Blog pembelajaran pada materi lain, disarankam untuk melihat tampilan, kejelasan tulisan serta dapat menyisipkan video agar Blog yang dikembangkan lebih menarik lagi sehingga siswa lebih tertarik lagi untuk melihat dan belajar dari Blog.

\section{Referensi}

Ariasari, Fany. 2006. Pernak-pernik Blog. Jakarta: Media Kita.

Azhar Arsyad. 2009. Media Pembelajaran. Jakarta: Raja Grafindo Persada.

Amrun Salam Riyadi. 2011. Pengembangan Media Pembelajaran Berbasis Komputer Untuk Mata Diklat Mengoprasikan Mesin CNC Dasar Di SMK Negeri 2 Depok 
Vol 2 No 2 Desember 2021

Jurnal AlphaEuclidEdu

Received: 05/10/2021; Resived: 11/11/2021; Accepted: 29/12/2021

Sleman Yogyakerta. Prodi Pendidikan Teknik Mesin Fakultas Teknik UNY.

Anggraeni, Rina. 2010. Pembuatan CD Pembelajaran Sestem Peredaran Darah Manusia Berbasis Flash. Skripsi F.MIPA: Universitas Sebelas Maret.

Andiani, W., \& Fitria, H. (2021). Pembelajaran Daring Menggunakan Media Online Selama Pandemi Covid-19 Pada Siswa Sd Negeri 103. 172-181.

Raisa, S., Adlim, A., \& Safitri, R. (2018). Respon Peserta Didik Terhadap Pengembangan Media Audio-Visual. Jurnal Pendidikan Sains Indonesia, 5(2), 8286. https://doi.org/10.24815/jpsi.v5i2.9821

Rizal, S., \& Walidain, B. (2019). Pembuatan Media Pembelajaran E-Learning Berbasis Moodle Pada Matakuliah Pengantar Aplikasi Komputer Universitas Serambi Mekkah. JURNAL ILMIAH DIDAKTIKA: Media Ilmiah Pendidikan Dan Pengajaran, 19(2), 178. https://doi.org/10.22373/jid.v19i2.5032

Brog, Walter, R \& Gall, Meredith, D, 1989. Educational research: An introducation. New York: Longman Inc.

Rohani, Ahmad. 1997. Media Intstruksional Edukatif. Jakarta: Rineka Cipta.

Sugiyono, 2017. Metode Penelitian Pendidikan Pendekatan Kuantitatif, Kuantitatif dan RnB Bandung: Alfabeta. 
Vol 2 No 2 Desember 2021

Jurnal AlphaEuclidEdu

Received: 23/09/2021; Resived: 15/11/2021; Accepted: 29/12/2021

\title{
PENGARUH PENDEKATAN REALISTIC MATHEMATIC EDUCATION (RME) TERHADAP HASIL BELAJAR PESERTA DIDIK DALAM MATERI LINGKARAN DI SMA PANCA SETYA SINTANG
}

\author{
Vonia Yulia Agustina, Ahmad Yani T, Romal Ijuddin \\ Program Studi Pendidiikan Matematika, FKIP, Universitas Tanjungpura, Pontianak \\ Email: voniayulia3107@gmail.com
}

\begin{abstract}
This review intends to decide the impact of practical arithmetic training approach on the learning results of class XI understudies in circle material at SMA Panca Setya Sintang. The exploration strategy utilized in this examination is an investigation with a single shot contextual analysis research plan. The populace in this review were understudies of class XI IPA SMA Panca Setya Sintang. While the examples utilized were understudies of class XI IPA 2 there were 24 apprentices. The method of gathering information on learning results utilizes estimation procedures by giving exposition test inquiries in circle material to understudies. To see the consistency in the accomplishment of learning results, then, at that point following two weeks, a postpone test is given. The normal score at the hour of the last test was 53.82, while the normal score at the hour of the deferred test was 55.56. In view of the estimation of the t-test normal of one example, the worth of $t_{\text {count }}=-0.26$ and $t_{\text {table }}=2.07$ with a huge degree of $=0.05$, this implies that $t_{\text {count }}<t_{\text {table }}$ thenis acknowledged implying that there is no huge contrast between the mean the normal worth of understudies at the hour of the last test and the postponed test. Then, at that point there is consistency between the last grades and the deferred test scores, this implies that the utilization of practical arithmetic training way to deal with the circle material influences understudy learning results.
\end{abstract}

Keywords: Impact, Realistic Mathematic Education, Learning Results

\section{Pendahuluan}

Permendikbud No. 22 tahun 2016 merupakan tujuan matematika dalam dunia pendidikan antara lain (a) memahami ide-ide matematika, menggambarkan bagaimana hubungan antara ide-ide matematika dan menerapkan ide-ide atau logaritma secara mahir, adaptif, benar, dan tepat dalam menangani masalah, (b) memikirkan contohcontoh gagasan matematika, menciptakan atau mengendalikan matematika dalam membangun argumen, membentuk bukti, atau menggambarkan argumen dan penjelasan matematika, (c) menangani masalah matematika yang menggabungkan kemampuan untuk mendapatkan masalah, mengembangkan model pengaturan matematika, model matematika lengkap, dan memberikan pengaturan yang sesuai, dan (d) menyampaikan pertentangan atau pemikiran dengan bagan, tabel, gambar, atau media lain untuk menjelaskan masalah atau keadaan. Tujuan ini menjelaskan bahwa kemampuan berpikir kritis harus digerakkan oleh peserta didik karena prestasi atau kekecewaan seseorang dalam matematika ditentukan oleh kemampuan untuk mengatasi masalah yang mereka hadapi.

Pada dasarnya tujuan tersebut telah dicapai oleh peserta didik yang mempelajarinya. Namun pada kenyataannya hasil pembelajaran matematika 
Vol 2 No 2 Desember 2021

Jurnal AlphaEuclidEdu

Received: 23/09/2021; Resived: 15/11/2021; Accepted: 29/12/2021

peserta didik tidak seperti yang diharapkan, karena banyak perolehan pembelajaran matematika peserta didik yang masih belum mencapai nilai KKM. Berdasarkan hasil pengamatan yang dilaksanakan peneliti pada kelas XI IPA 2 SMA Panca Setya Sintang, dapat diketahui bahwa selama proses pembelajaran masih terdapat guru yang mengajar dengan menggunakan metode ceramah yaitu proses belajar mengajar hanya berpusat pada guru saja sebagai pemberi bahan pelajaran dan peserta didik mendengarkan. Aktivitas peserta didik dalam pembelajaran masih kurang, interaksi antara guru dengan peserta didik dan peserta didik dengan teman sebayanya jarang terjadi selama proses Pembelajaran (Saputro et al., 2015).

Guru saat menerangkan materi pembelajaran beberapa peserta didik tidak menyimak, ditemukan juga peserta didik yang bercerita dengan teman sekelasnya, ketika guru memberikan kesempatan peserta didik untuk menyajukan bertanya, peserta didik tidak memanfaatkannya dengan baik, mereka hanya memilih untuk diam, dan ketika diminta mengerjakan tugas mereka hanya menyalin jawaban dari temannya tanpa ingin berdiskusi untuk menyelesaikan masalah. Hal ini menunjukkan bahwa interaksi yang terjadi antara peserta didik dan guru selama proses pembelajaran masih kurang, pada saat diskusi kelas hanya sedikit peserta didik yang aktif, sehingga peserta didik lainnya hanya berperan sebagai pendengar yang tidak mau mengemukakan pendapat.

Ketiadaan pemahaman peserta didik pada topik tersebut menyebabkan rendahnya perolehan pembelajaran matematika. Data konsekuensi ulangan harian pada materi lingkaran di kelas XI IPA 2 tahun pelajaran 2019/2020. Dari 36 peserta didik tersebut, hanya 12 peserta didik atau 33,33\% yang tuntas dan 24 peserta didik atau $66,66 \%$ tidak tuntas, sedangkan pemenuhan ketuntasan klasikal di sekolah seharusnya $85 \%$. Nilai ulangan harian normal yang didapat adalah 53, tidak mencapai Kriteria Ketuntasan Minimal (KKM) yaitu pada taksiran 75. Opsi yang dipandang siap menggerakkan peserta didik saat menimba ilmu ialah dengan menggunkaan pendekatan pelajaran yang dapat membuat peserta didik antusias, lingkungan belajar yang mempesona, sehingga dapat menggairahkan ketertarikan dan animasi peserta didik dalam belajar matematika. Salah satu aplikasi yang menurut peneliti tepat adalah pendekatan Realistic Mathematic Education (RME).

Pemikiran tersebut menyinggung penilaian Freudenthal (1985: 5) yang mengemukakan bahwa matematika harus diidentikkan dengan dunia nyata dan matematika adalah gerakan manusia. Pendekatan RME adalah pendekatan pengajaran yang dimulai dari dunia nyata untuk peserta didik, menekankan keterampilan siklus melakukan percakapan matematika dan upaya bersama, bersaing bersama kawan sekolah jadi mereka bisa mencari tahu sendiri dan pada akhirnya menggunakan matematika untuk mengurusi kegiatan positif sebagai mandiri meskipun dalam musyawarah Zainal, dalam (Sari 2010: 1). Dalam metode ini tugas guru hanyalah fasilitator, moderator atau evaluator sementara peserta didik berpikir, menyampaikan, melatih seluk-beluk pemerintahan mayoritas dengan memperhatikan penilaian orang 
Vol 2 No 2 Desember 2021

Jurnal AlphaEuclidEdu

Received: 23/09/2021; Resived: 15/11/2021; Accepted: 29/12/2021

lain (Rosyada et al., 2019).

Secara hipotesis, RME dapat bekerja pada kemampuan peserta didik untuk mengatasi masalah matematika. Hal ini sesuai dengan hasil penelitian Evi Soviawati (2011) bahwa pendekatan RME adalah suatu metodologi yang menempatkan kebenaran dan pengalaman peserta didik sebagai tahap awal untuk menyadari dimana peserta didik ditawarkan kesempatan untuk mengembangkan informasi matematika formal mereka sendiri melalui masalah faktor nyata yang ada. Menggunakan strategi RME, peserta didik tidak saja gampang mendominasi ide dan topik, melaikan juga tidak bersungguhsungguh gagal mengingat hal yang sudah mereka peroleh pada belajar matematika (Elwijaya et al., 2021).

Mengingat dasar masalah, peneliti tertarik untuk mengarahkan penelitian bernama "Pengaruh Pendekatan Realistic Mathematic Education (RME) Terhadap Hasil Belajar Peserta Didik Kelas XI Dalam Materi Lingkaran di SMA Panca Setya Sintang”. Maka tujuan dari penelitian ini adalah: (1) untuk mengetahui hasil belajar peserta didik yang normal pada materi lingkaran di kelas XI SMA Panca Setya Sintang setelah diperlihatkan pemahaman menggunakan pendekatan Realistic Mathematik Education $(R M E)$; (2) untuk mengetahui hasil belajar normal peserta didik kelas XI di SMA Panca Setya Sintang dengan menggunakan pendekatan Realistic Mathematic Education (RME) setelah diberikan tes tunda; (3 ) untuk melihat apakah terdapat perbedaan signifikan antara nilai tes akhir dan skor tes ditunda peserta didik pada materi lingkaran kelas XI di SMA Panca Setya Sintang setelah diperlihatkan mengambil menggunakan pendekatan Realistic Mathematik Education (RME).

Ketercapaian penelitian yang diharapkan mau ditunjukkan dengan konsistensi pencapaian perolehan nilai. Hasil belajar yang disinggung pada analisis ini adalah penguasaan peserta didik dalam materi lingkaran yang ditunjukkan dengan perolehan nilai dari hasil tes yang diperoleh peserta didik setelah diperlihatkan menguasai penggunaan pendekatan Realistic Mathematic Education (RME). Menurut Sudjana (2009:22) hasil belajar adalah peserta didik yang mampu menerima pembelajaran yang telah diberikan. Dengan kata lain, penilaian hasil belajar diisi sebagai instrumen untuk menentukan pencapaian dalam sistem pembelajaran.

\section{Metode Penelitian}

Penelitian ini menggunakan metode eksperimen. Menurut Sugiyono (2013:107) menyatakan bahwa, "metode eksperimen adalah suatu metode yang digunakan untuk mencari pengaruh perlakuan tertentu terhadap orang lain dalam kondisi yang terkendali". Bentuk penelitian ini yakni pre-experimental design dengan desain penelitian The One-Shot Case Study ditambah Delayed Test. Desain ini dapat disajikan dalam tabel berikut:

Tabel 1. Rancangan Penelitian One-Shot Case Study

\begin{tabular}{|c|c|c|}
\hline Treatment & \multicolumn{2}{|c|}{$\mathrm{O}$} \\
\hline $\mathrm{X}$ & $\mathrm{O}_{1}$ & $\mathrm{O}_{2}$ \\
\hline
\end{tabular}


Vol 2 No 2 Desember 2021

Jurnal AlphaEuclidEdu

Received: 23/09/2021; Resived: 15/11/2021; Accepted: 29/12/2021

\footnotetext{
Keterangan:

$\mathrm{X}=$ Pembelajaran pada kelas eksperimen menggunakan pendekatan Realistic Mathematic Education (RME).

$O_{1} \quad=$ Tes yang diberikan setelah dilakukan pembelajaran menggunakan pendekatan Realistic Mathematic Education (RME) (Posttest).

$\mathrm{O}_{2} \quad=$ Tes yang diberikan setelah dua minggu kemudian, untuk melihat kembali kemampuan peserta didik (Delayed Test). (Suryabrata, 2010: 100)
}

Populasi adalah wilayah spekulasi yang terdiri dari objek/subyek yang memiliki karakteristik atau atribut tertentu yang didiktekan oleh peneliti untuk dikonsentrasikan dan kemudian ditarik kesimpulan (Sugiyono, 2013:117). Populasi dalam penelitian ini adalah peserta didik kelas XI IPA SMA Panca Setya Sintang. Seperti yang ditunjukkan oleh Sugiyono (2013: 118) "sampel sangat penting untuk jumlah dan kualitas yang digerakkan oleh populasi tersebut". Memeriksa tergantung pada wilayah populasi yang ditentukan sebelumnya. Jadi sampel dalam penelitian ini adalah tes populasi, khususnya peserta didik kelas XI IPA 2 SMA Panca Setya Sintang.

Strategi yang dilakukan dalam penelitian ini meliputi tiga tahap, yaitu: (1) Tahap Persiapan, latihan yang dilakukan selama kesiapan meliputi: menyebutkan fakta-fakta yang dapat diamati di SMA Panca Setya Sintang, mengumpulkan rencana penelitian, membuat instrumen penelitian, menguji instrumen penelitian, menyetujui instrumen ujian, dan menyelidiki informasi dari konsekuensi pengujian instrumen penelitian; (2) Tahap pelaksanaan, latihan yang dilakukan adalah: menawarkan perlakuan pada kelas eksplorasi dengan pengambilan RME, menawarkan tes akhir ke kelas trial, dan memberikan tes tunda setelah dua minggu; (3) Tahap Terakhir, latihan yang dilakukan pada tahap terakhir meliputi: membedah informasi yang didapat dengan uji statistik yang tepat, menutup efek samping dari penanganan informasi sebagai jawaban untuk mengeksplorasi masalah, dan menyusun laporan penelitian.

Strategi pengumpulan informasi yang digunakan dalam penelitian ini adalah prosedur pengukuran. Menurut Nawawi (2005: 95) strategi estimasi adalah metode pengumpulan informasi kuantitatif untuk menentukan tingkat atau tingkat sudut tertentu yang dikontraskan dengan standar tertentu sebagai unit estimasi yang signifikan. Strategi estimasi dalam penelitian ini adalah dengan memberikan tes soal essay dalam materi lingkaran kepada peserta didik. Instrumen ragam informasi yang digunakan adalah soal tes. Pengujian dikendalikan dua kali, untuk lebih spesifik pengaturan tes terakhir (posttest) dan tes yang ditangguhkan (delayed test), pertanyaan yang digunakan untuk pengujian adalah pertanyaan serupa. Informasi yang diperoleh dari hasil tes ditangani sesuai langkah analisisnya: untuk menjawab pertanyaan pertama dan kedua diperiksa menggunakan statistik deskriptif,langkah-langkahnya adalah: (1) menilai hasil tes akhir dan hasil tes tertunda, (2) mengubah skor menjadi jenis nilai signifikan, (3) mencari nilai rata-rata tes akhir dan tes tunda. Sementara itu, untuk menjawab soal 
Vol 2 No 2 Desember 2021

Jurnal AlphaEuclidEdu

Received: 23/09/2021; Resived: 15/11/2021; Accepted: 29/12/2021

ketiga, itu diselidiki dengan menggunakan statistikparametrik dan data nilai tes akhir dan tes tunda peserta didik ditentukan normalitasnya menggunakan persamaan chikuadrat. Dengan asumsi skor tes posttest dan delayed testberedar secara teratur, lanjutkan dengan uji-t tes rata-rata satu sampel.

\section{Hasil dan Pembahasan}

Dari latihan penelitian yang dipimpin selama dua pertemuan di kelas XI MIPA 2 SMA Panca Setya Sintang, informasi yang diperoleh dari hasil belajar peserta didik, menjadi informasi hasil tes dan tes tertunda tertentu sebagai kualitas yang dikonversi dari perhitungan absolut yang didapatkan setiap peserta didik. Nilai hasil belajar dapat dilihat pada tabel berikut:

Tabel 2. Data Perolehan Posttest dan Delayed Test

\begin{tabular}{|c|c|c|c|}
\hline No & Kode Peserta Didik & Nilai Posttest & Nilai Delayed Test \\
\hline 1 & A1 & 75 & 25 \\
\hline 2 & $\mathrm{~A} 2$ & 66,7 & 50 \\
\hline 3 & A3 & 50 & 50 \\
\hline 4 & A4 & 66,7 & 25 \\
\hline 5 & A5 & 83,3 & 83,3 \\
\hline 6 & A6 & 25 & 50 \\
\hline 7 & A7 & 50 & 91,7 \\
\hline 8 & A8 & 25 & 66,7 \\
\hline 9 & A9 & 25 & 91,7 \\
\hline 10 & A10 & 50 & 66,7 \\
\hline 11 & A11 & 25 & 83,3 \\
\hline 12 & A12 & 25 & 75 \\
\hline 13 & A13 & 50 & 66,7 \\
\hline 14 & A14 & 83,3 & 75 \\
\hline 15 & A15 & 91,7 & 66,7 \\
\hline 16 & A16 & 50 & 50 \\
\hline 17 & A17 & 75 & 25 \\
\hline 18 & A18 & 50 & 25 \\
\hline 19 & A19 & 66,7 & 50 \\
\hline 20 & $\mathrm{~A} 20$ & 66,7 & 66,7 \\
\hline 21 & $\mathrm{~A} 21$ & 50 & 50 \\
\hline 22 & A22 & 25 & 25 \\
\hline 23 & A23 & 50 & 25 \\
\hline 24 & A24 & 66,7 & 50 \\
\hline \multicolumn{2}{|r|}{ Rata-rata } & 53,82 & 55,56 \\
\hline \multicolumn{2}{|r|}{ SD } & 20,82 & 22,21 \\
\hline
\end{tabular}


Vol 2 No 2 Desember 2021

Jurnal AlphaEuclidEdu

Received: 23/09/2021; Resived: 15/11/2021; Accepted: 29/12/2021

Mengingat dampak dari tes akhir dan tes tunda, ditemukan maka skor tertinggi yang didapat peserta didik pada saat tes akhir sebesar 91,7(1 peserta didik) dan skor terendah adalah 25 (6 peserta ) dari nilai lengkap dari 100. Hasil belajar peserta didik normal pada saat tes akhir adalah $=53,82$ dengan standar deviasi $(\mathrm{SD})=20,82$. Sedangkan nilai tertinggi yang diperoleh peserta didik saat tes tunda adalah 91,7 (2 peserta didik) dan skor terendah adalah 25 (6 peserta didik) dari nilai mutlak 100. Hasil belajar peserta didik normal selama tes tunda adalah $=55,56$ dengan simpangan baku $(\mathrm{SD})=22,21$.

Data nilai tes akhir dan tes tunda ditentukan kewajarannya dengan memanfaatkan uji chi-kuadrat. Dari hasil estimasi tes akhir diperoleh $X^{2}{ }_{\text {hitung }}=9,81$ dan $X_{\text {tabel }}^{2}=11,07$ dengan $\alpha=0,05$.Sedangkan konsekuensi dari estimasi data tes tunda didapat diperoleh $X_{\text {hitung }}^{2}=9,40$ dan $X_{\text {tabel }}^{2}=11,07$ dengan taraf kesalahan $\alpha=0,05$. Data nilai tes akhir dan tes tunda biasanya berdistribusi normal jika $X_{\text {hitung }}^{2}<X_{\text {tabel, }}^{2}$ dengan alasan $X^{2}$ hitung pada kedua informasi nilai hasil belajar peserta didik kurangdari $X^{2}$ tabel, maka dapat disimpulkan bahwa informasi tes akhir dan tes tunda tersebar secara teratur.

Sejak tes akhir dan informasi tes tunda berdistribusi normal biasanya disesuaikan, itu diikuti oleh uji statistik parametrik menggunakan uji-t tes rata-rata satu sampel.Uji ini diarahkan untuk memutuskan apakah ada perbedaan signifikan antara nilai tes akhir dan skor tes tunda. Dilihat dari estimasi uji-t tes rata-rata satu sampel diperoleh nilai thitung $=-0,26$ dan tabel $=2,07$ dengan $a=0,05$, hal ini bearti thitung $<t_{\text {tabel }}$ jadi Ho diakui, berakibat bahwa tidak kelihatan selisih signifikan antara nilai normal peserta didik selama tes akhir dan tes tunda.

\section{Pembahasan Rata-rata Hasil Belajar}

Berdasarkan informasi tes akhir dan tes tunda, didapati bahwa perolehan belajar peserta didik yang normal saat tes akhir sebesar $\bar{x}=53,82$ dengan skor tertinggi yang diperoleh peserta didik pada tes akhir adalah 91,7 didapatkan 1 orang peserta didik dan skor terendah adalah 25 diperoleh 6 orang peserta ddiik dari nilai mutlak 100 . Sedangkan hasil belajar siswa yang normal pada tes tunda adalah $\bar{x}=55$,56dengan skor tertinggi yang diperoleh peserta didik pada tes tunda adalah 91,7 yang diperoleh 2 orang peserta didik dan nilai terkecil adalah 25 didapatkan 6 orang peserta didik dari skor absolut 100. Mengingat efek samping dari penggambaran informasi, skor normal peserta didik selama tes akhir berada di bawah normal untuk tes tunda. Dalam proses belajar mengajar peserta didik diharuskan untuk lebih bersungguh-sungguh dan kreatif, peserta didik diharuskan supaya berusaha menemukanpengetahuan maupun pemecahan masalah dari berbagai sumber yang ada, peserta didik juga senang dan aktif dalam mengikuti proses pembelajaran dengan menggunakan pendekatan Realistic Mathematic Education (RME).

Pembahasan Pengaruh Pendekatan Realistic Mathematic Education (RME) terhadap Hasil Belajar 
Vol 2 No 2 Desember 2021

Jurnal AlphaEuclidEdu

Received: 23/09/2021; Resived: 15/11/2021; Accepted: 29/12/2021

Ketika informasi tes akhir dikontraskan dengan informasi tes tunda, diketahui bahwa hasil belajar peserta didik normal pada tes akhir secara empirik berbeda dengan hasil belajar peserta didik normal selama tes tunda. Hasil belajar peserta didik yang normal melalui tes diperbolehkan setelah dua minggu setelah mengalami peningkatan dari efek samping normal dari tes sebelumnya. Nilai normal pada saat tes akhir adalah 53,82, sedangkan nilai normal pada saat tes tunda adalah 55,56. Dari nilai normal siswa pada saat tes akhir dan tes tunda cenderung terlihat adanya kontras normal sebesar 1,74.

Bagaimanapun, perbedaan ini harus dicoba lagi dengan sungguh-sungguh, karena data tes akhirdan tes tunda berdistribusi normal maka untuk, jadi untuk melihat apakah ada perbedaan besar antara skor tes akhir dan tes tertunda, uji-t tes rata-rata satu sampel yang digunakan. Mengingat perhitungan normal uji-t tes rata-rata satu sampel dengan derajat besar $=0,05$, maka diperoleh nilai $t_{\text {hitung }}=-0,26$ dan $t_{\text {tabel }}=2,07$, hal ini bearti $t_{\text {hitung }}<t_{\text {tabel }}$ hingga Ho diakui yang mengakibatkan bahwa tidak ada kontras besar antara nilai normal peserta didik selama tes akhir dan tes tunda.

Hasil analisis data adalah bahwa tidak ada perbedaan kritis antara nilai normal peserta didik selama tes akhir dan tes tunda, ini sesuai dengan spekulasi normal, khususnya ada konsistensi dalam pencapaian hasil belajar. Tanpa perbedaan kritis dalam efek samping dari tes akhir dan tes tunda, ada konsistensi antara skor tes akhir dan tes tunda. Hal ini membuktikan bahwa implikasi Realistic Mathematic Education $(R M E)$ dalam materi lingkaran mempengaruhi hasil belajar peserta didik.

Berdasarkan nilai normal peserta didik pada saat tes akhir dan tes tunda, dapat disimpulkan bahwa nilai normal peserta didik pada tes akhirt agak setara dengan nilai normal peserta didik selama tes tunda. Pada saat proses belajar mengajar berlangsung peserta didik diharuskan agar bertambah dinamis maupun inovatif, peserta didik diminta agar menemukan pengetahuan juga berpikir jernih saat pemecahan masalah dari berbagai sumber yang mudah diakses, peserta didik juga senang dan aktif dalam mengikuti sistem pembelajaran dengan menggunakan pendekatan Realistic Mathematic Education (RME). Peserta didik sangat antusias dengan hal-hal baru yang dilakukan oleh para peneliti, karena belajar menggunakan pendekatan Realistic Mathematic Education (RME) berhubungan dengan pengalaman dan rutinitas peserta didik seharihari sebagai tahap awal untuk belajar matematika.

\section{Kesimpulan dan Saran}

Berdasarkan hasil pengolahan data penelitian, maka hasil akhir yang diperoleh dari tinjauan ini adalah sebagai berikut: (1) Hasil belajar peserta didik yang normal pada materi lingkaran melalui penggunaan pendekatan Realistic Mathematic Education (RME) adalah 53,82 dengan skor paling penting yang didapat oleh peserta didik adalah 91,7 (1 peserta didik) dan skor paling sedikit adalah 25 (6 peserta didik); (2) Hasil belajar peserta didik normal pada materi lingkaran melalui penggunaan pendekatan Realistic Mathematic Education (RME) setelah diberikan tes tunda adalah 55,56 dengan nilai tertinggi yang diperoleh peserta didik adalah 91,7 (2 peserta didik) paling sedikit 
Vol 2 No 2 Desember 2021

Jurnal AlphaEuclidEdu

Received: 23/09/2021; Resived: 15/11/2021; Accepted: 29/12/2021

adalah 25 (6 peserta didik); (3) Tidak diperoleh selisih mencolok antara nilai normal peserta didik pada tes akhir dan tes tunda, hal ini menunjukkan bahwa penggunaan cara Realistic Mathematic Education (RME) untuk menangani materi lingkaran berpengaruh terhadap hasil belajar peserta didik kelas XI IPA 2 SMA Panca Setya Sintang.

Catatan penting yang perlu dilakukan berdasarkan penelitian ini: (1) Dalam penggunaan pendekatan RME, lebih baik bagi guru atau peneliti lebih lanjut untuk menggunakan bantuan instruksi yang tidak hanya relevan masalah sebagai cerita atau gambar. Artinya mempermudah mahasiswa untuk mendapatkan data karena mahasiswa melihat hal-hal yang lebih substansial dari pada dinamis; (2) Dalam penggunaan pendekatan RME, pengajar atau ilmuwan juga harus menambahkan latihan-latihan pembelajaran, khususnya mengaitkan ide dengan pemanfaatannya dalam kehidupan sehari-hari, sehingga peserta didik memahami hipotesis serta menerapkannya dalam kehidupan sehari-hari. ; (3) Penelitian saya ini terkena ancaman implementor karena implementornya saya sendiri, oleh sebab itu pada peneliti yang lain mungkin sebaiknya implementornya bukan peneliti bisa saja guru.

\section{Referensi}

Freudenthal, H. (1985). Develoving Realistic Mathematic Education. Freudenthal Institute: Utrecht.

Nawawi, H. (2005). Metode Penelitian Bidang Social. Yogyakarta: Gajah Mada University Press.

Permendikbud. (2016). Peraturan Menteri Pendidikan dan Kebudayaan Republik Indonesia No. 22 Tahun 2016 Tentang Standar Proses Pendidikan Dasar dan Menengah.

Elwijaya, F., Harun, M., \& Helsa, Y. (2021). Implementassi Pendekatan Realistic Mathematics Education (RME) di Sekolah Dasar. Jurnal Basicedu, 5(2), 741-748. https://doi.org/10.31004/basicedu.v5i2.796

Rosyada, T. A., Sari, Y., \& Cahyaningtyas, A. P. (2019). Pengaruh Model Pembelajaran

Realistic Mathematics Education (Rme) Terhadap Kemampuan Pemecahan

Masalah Matematika Siswa Kelas V. Jurnal Ilmiah Pendidikan Dasar, 6(2), 116. https://doi.org/10.30659/pendas.6.2.116-23

Saputro, M., Yadi, A., \& Dona, F. (2015). Faktor-Faktor yang Mempengaruhi Prestasi

Belajar (Studi Korelasi Pada Mahasiswa Pendidikan Matematika IKIP PGRI Pontianak). Jurnal Pendidikan Informatika Dan Sains, 4(2), 233-246.

Soviawati, Evi. (2011). Pendekatan Matematika Realistik (PMR) Untuk Meningkatkan Kemampuan Berpikir Siswa Di Tingkat Sekolah Dasar. Jurnal Universitas Pendidikan Indonesia Vol. 9 No 2, halaman 79-85: http://jurnal.upi.edu/file/9Evi_Soviawati-edit.pdf. (Jum'at, 30 November 2012).

Sudjana, Nana. (2009). Penilaian Hasil Proses Belajar Mengajar. Bandung: PT. Remaja Rosdakarya.

Sugiyono. (2013). Metode Penelitian Pendidikan. Bandung: Alfabeta.

Suryabrata, Sumadi. (2010). Metodologi Penelitian. Jakarta: Rajawali. 
Vol 2 No 2 Desember 2021

Jurnal AlphaEuclidEdu

Received: 02/02/2021; Resived: 13/09/2021; Accepted: 29/12/2021

PENERAPAN MODEL PEMBELAJARAN STRUCTURE NUMBERED HEADS MATERI OPERASI HITUNG BILANGAN PECAHAN MTS AL-FATHAANAH MEMPAWAH HILIR

\author{
Nopita Sari ${ }^{1}$, Agung Hartoyo ${ }^{2}$, Dede Suratman ${ }^{3}$ \\ ${ }^{1,2,3}$ Pendidikan Matematika, FKIP, Universitas Tanjungpura, Pontianak \\ Email: snopita554@gmail.com
}

\begin{abstract}
In the study effectiveness is very important, learning is said to $b$ e successful when learners and educators can achieve the objectives to be reached. The effectiveness of what this researchsats is the learning activities performed by the teacher in administering the materials to be presented, the study activity, and the learning result of the learners. The purpose of the researchto see the effectiveness of these three aspects in applying the research Structure Numbered Heads to the operating material VII MTs. Al-Fataanah Memapawah Hilir. The method used in research is experimental method, with the shape of the research is a One-Shot Case Study. The subjects in this study are VII-A class learners and teachers at MTs. Al-Fataanah Mempawah Hilir. Research data is obtained from the administration of study tests (posttest), the learning management observation sheet and the observation sheet of participants activities. The result of all three learning effectiveness is that the learning process applies 3,04 cooperative types of Structure Numbered Heads to good categories, learning activity percentage is $68,9 \%$ in the active category, learners can achieve the greatest learning result of individual achievement of 8 or $40 \%$ and classified intellgence is not lade. Since there is an unfulfilled indicator that the achievement of classified learning will not be achieved it seems that the study of applying cooperative models Structure Numbered Heads is not effective to apply in program class MTs. Al-Fataanah Mempawah Hilir.
\end{abstract}

Keywords: Model, Learning, Structure Numbered Heads

\title{
1. Pendahuluan
}

Pembelajaran adalah kegiatan yang berlangsung melalui langkah pembentukan, penerapan, dan penilaian, dimaknai seperti korelasi peserta didik dengan guru dan referensi belajar dalam suatu cangkupan melatih diri. Pembelajaran ialah koneksi dua arah, mendidik dijalankan oleh golongan guru selaku pendidik, sementara itu menggali ilmu diperankan oleh peserta didik atau murid. Pendidikan bersumber pada kurikulum 2013 melibatkan pelajar, peluang bagi pelajar membangun kemampuan yang dipunyainya baik dalam perilaku (spiritual dan sosial), intelektual, ataupun keahlian, dimana pendidikan harus berfokus pada peserta didik (Permendikbud No. 104 Tahun 2014, tentang Pembelajaran). Para pengajar matematika setuju bahwa para peserta didik hendaklah mendalami matematika (Hilbert \& Carpenter dalam Van de Walle, $2008: 23$ ).

Hal ini tentunya tidak lepas dari komponen efektivitas dalam pembelajaran itu sendiri. Efektivitas dalam pembelajaran tidak sekedar ditinjau dari peserta didik saja, 
Vol 2 No 2 Desember 2021

Jurnal AlphaEuclidEdu

Received: 02/02/2021; Resived: 13/09/2021; Accepted: 29/12/2021

melainkan dilihat dari cara pendidik mengusahakan pendidikan, keaktifan pelajar ketika belajar, dengan hasilnya yang dicapai pelajar setelah mengikuti pembelajaran. Dalam pembelajaran matematika sasaran utama yang diukur adalah tujuan pembelajaran matematika.

Akan tetapi pada kenyataan, kebenaran nan berlangsung di lapangan tidak sejalan pada apa yang di inginkan.pada hasil wawancara dari salah seorang pengajar mata pelajaran matematika di MTs. Al-Fathaanah Mempawah Hilir, Ia mengungkapkan walaupun sekolah telah menerapkan Kurikulum 2013 aktivitas pembelajaran matematika terkadang masih merepakan model konvensional, semacam teknik ceramah, penugasan, dan tanya jawab hal ini dikarenakan ada beberapa materi yang sulit untuk dipahami peserta didik salah satunya melakukan penjumlahan dan pengurangan pada bilangan pecahan yang memiliki penyebut berbeda sehingga membuat peserta didik merasa kebingungan

Peserta didik masih kesulitan ketika menyamakan penyebut dan kebingungan dalam menyelesaikan soal cerita. Lebih lanjut lagi salah satu guru matematika disana yaitu Nuraisyah S.Pd, mengungkapkan bahwa lemahnya interpretasi peserta didik mengenai operasi penjumlahan dan pengurangan sehingga peserta didik menjadi kesusahan dalam menerapkan operasi-operasi yang seterusnya, yakni perkalian dan pembagian. Dari fakta tersebut interpretasi peserta didik pada operasi bilangan pecahan masih lemah. Oleh karena itu, sebesar 15 atau 70\% dari 20 peserta didik belum mencapai ketuntasan minimal yaitu 75. Aktivitas pembelajaran yang diterapkan yakni, penyampaian ulasan perihal pelajaran yang akan dibelajarakan, pemberian contoh soal, dan pembagian tugas setelah itu didiskusikan bersama. Bagi peserta didik yang pasif tentu membuatnya kurang aktif dalam belajar sehingga kesulitan dalam memahami materi yang diajarkan akan menjadi masalah untuk mereka (Putri et al., 2020).

Perlu adanya pembaharuan dalam melaksanakan kegiatan belajar dengan model kooperatif, dimana peserta didik dapat bertukar informasi agar terjadinya pemahaman sekitar peserta didik secara berlainan, terciptanya pembelajaran yang ampuh, tenang, menarik dan praktis perlu ada suatu bentuk pembelajaran kooperatif (Sari et al., 2021). Dalam hal ini perlu diadakan pembaruan dalam kegiatan belajar, salah satu bentuk yang tentu menolong pendidik terus meningkatkan hasil belajar, kegiatan belajar, dan proses pembelajaran guru mengelola pembelajaran adalah model Structure Numbered Heands (Kepala Bernomor Sruktur).

Structure Numbered Heads (SNH) ialah salah satu contoh pengajaran berasaskan kooperatif yang menekankan keefektivitas melatih diri bagi pelajar dalam memperoleh, mengola, dan menyampaikan laporan yang didapat dari beragam sumber lalu disampaikan. Peserta didik belajar memenuhi tanggung jawab personalnya dan saling keterlibatan dengan teman kelompoknya (Lie, 2010). Tujuan dari bentuk pengajaran Structure Numbered Heads yaitu peserta didik sanggup bekerja sama, bertanggung jawab, saling membantu menyelesaikan pertanyaan dan saling memacu satu sama lain untuk meningkatkan prestasi belajar, meringankan saat pembagian tugas setiap siswa dalam kelompok lalu dapat menumbuhkan efektivitas siswa.

\section{Metode Penelitian}


Vol 2 No 2 Desember 2021

Jurnal AlphaEuclidEdu

Received: 02/02/2021; Resived: 13/09/2021; Accepted: 29/12/2021

Pada percobaan ini memakai teknik penelitian eksperimen. Menurut Nawawi (2012: 3), penelitian eksperimen merupakan proses penyelesaian persoalan yang diamati dengan menggambarkan/melukiskan keadaan subyek/obyek peyelidikan (seseorang, lembaga, masyarakat dan lain-lain) untuk kesempatan masa kini bersumberkan buktibukti yang terlihat, atau sebagaimana adanya. Eksperimen ini bertujuan untuk mendapat informasi dengan cara mendeskripsikan keefektivitas model kooperatif tipe Structure Numbered Heads.

Bersumber pada rancangan eksperimen yang dipakai, sehingga bentuk rancangannya ialah One-Shot Case Study. Sistem akumulasi informasi yang dipakai pada rancangan ini ialah teknik pengukuran. dilakukan dengan pemberian skor terhadap kemampuan peserta didik dalam menyelesaikan soal tes hasil belajar (post-test) dan teknik observasi langsung dilaksanakan ketika guru mengawali pembelajaran dan ketika guru mengakhiri pelajaran. Penelitian ini dilaksanakan kedalam tiga tahapan, yakni 1) persiapan, 2) pelaksanaan, 3) akhir.

\section{Hasil dan Pembahasan \\ Hasil penelitian}

Hasil penelitian dan penjabaran ini bersumber pada informasi yang telah didapatkan dari aktivitas penelitian yang dilakukan selama dua Kali pertemuan di kelas VII MTs. AL - Fathaanah Mempawah Hilir. Percobaan ini dilrealisasikan pada tanggal 30 November sampai dengan tanggal 03 Desember 2020. Data yang didapat mencakup informasi hasil pengamatan proses pembelajaran pendidik dalam mengusahakan pengajaran, informasi hasil peninjauan kegiatan melatih diri pelajar, dan data hasil belajar murid menggunakan model penataran Structure Numbered Heads pada materi operasi hitung bilangan pecahan kelas VII MTs. AL-Fathaanah Mempawah Hilir.

Tabel 1. Deskripsi Hasil Observasi Proses Pembelajaran Guru dalam Mengelola Pembelajaran

\begin{tabular}{|c|c|c|c|}
\hline \multirow{2}{*}{ No } & \multirow{2}{*}{ Kegiatan } & \multicolumn{2}{|c|}{ Pertemuan } \\
\cline { 3 - 4 } & & Rata-rata & Keterangan \\
\hline 1 & Pendahuluan & 3,33 & Baik \\
\hline 2 & Inti & 3 & Baik \\
\hline 3 & Penutup & 2,8 & Baik \\
\hline & Rata-rata & 3,04 & Baik \\
\hline
\end{tabular}

Tabel 2. Rekapitulasi Aktivitas Belajar Peserta Didik

\begin{tabular}{|l|c|c|c|}
\hline \multirow{2}{*}{ No } & Kategori Aktivitas Peserta Didik & Persentase (\%) & \multirow{2}{*}{$\begin{array}{c}\text { Kategori } \\
\text { Aktivitas }\end{array}$} \\
\cline { 3 - 3 } & & Pertemuan & Sangat aktif \\
\hline 1 & Visual activities & $85 \%$ & Cukup aktif \\
\hline 2 & Oral activities & $51,6 \%$ & Aktif \\
\hline 3 & Listening activities & $79 \%$ & Cukup aktif \\
\hline 4 & Writing activities & $60 \%$ & Aktif \\
\hline
\end{tabular}


Vol 2 No 2 Desember 2021

Jurnal AlphaEuclidEdu

Received: 02/02/2021; Resived: 13/09/2021; Accepted: 29/12/2021

Tabel 3. Skor dan Nilai Hasil Belajar Peserta Didik

\begin{tabular}{|c|c|}
\hline Keterangan & Skor \\
\hline Rata- rata & 56,7 \\
\hline Skor Tertinggi & 83 \\
\hline Skor Terendah & 17 \\
\hline Banyak Peserta Didik Tuntas & 8 \\
\hline Banyak Peserta Didik Tidak Tuntas & 12 \\
\hline
\end{tabular}

\section{Pembahasan}

Bersumber pada hasil kajian yany sudah diuraikan diatas dari ketiga keefektifan pendidikan ditemukan bahwa prosedur pengajaran menggunakan model kooperatif tipe Structure Numbered Heads sebanyak 3,04 pada golongan baik, persentase aktivitas peserta didik $68,9 \%$ pada kategori aktif, peserta didik dapat memperoleh ketuntasan hasil belajar yakni ketuntasan secara personal berjumlah 8 peserta didik atau sebesar 40\% dan ketuntasan secara klasikal tidak terpenuh. Dalam hal ini terdapat satu komponen tak terlaksana yakni ketuntasan hasil belajar secara klasikal tidak terpenuhi karena hanya $40 \%$ peserta didik yang tuntas secara klasikal. maka dapat disimpulkan bahwa pembelajaran menerapkan model kooperatif tipe Structure Numbered Heads tidak efektif untuk digunakan dalam materi operasi hitung bilangan pecahan di kelas VII MTs. Al- Fathaanah Mempawah Hilir.

Model Structure Numbered Heads merupakan modifikasi dari model Numbered Heads Together sehingga kedua model ini sejenis dalam proses pelaksanaan dan juga penerapannya. Hasil penelitian yang telah dilakukan kali ini kurang sejalan dengan beberapa hasil penelitian seperti yang telah dilakukan sebelumnya seperti penelitian dari (Putra \& Rery, n.d.), dengan judul "Pembelajaran Kooperatif Tipe Structure Numbered Heads Pada Mata Pelajaran Geografi di SMAN 5 Bandung Kelas XII IIS B Semester 2(ganjil) Tahun Ajaran 2014/2015" bahwa penerapan model pembelajaran Structured Numbered Heads dapat meningkatkan hasil belajar peserta didik pada pokok bahasan Struktur Atom dan Sistem Periodik Unsur di kelas X MIA SMAN 5 Pekanbaru. Besarnya pengaruh penerapan model pembelajaran Structured Numbered Heads terhadap peningkatan prestasi belajar siswa pada pokok Struktur Atom dan Sistem Periodik Unsur di kelas X SMAN 5 Pekanbaru sebesar 14,14\%.

Penelitian yang sama juga telah dilakukan oleh (Hardianti et al., 2019), tentang "Penerapan Model Pembelajaran Kooperatif Tipe Kepala Bernomor Struktur untuk Meningkatkan Prestasi Belajar Siswa pada Pokok Bahasan Ikatan Kimia di Kelas X SMAN 11 Pekanbaru" dengan hasil penelitiannya menunjukkan bahwa Penerapan Model Pembelajaran Kepala Bernomor Struktur berhasil meningkatkan prestasi belajar 4 siswa yaitu sebesar 7,93\%.

\section{Simpulan dan Saran Simpulan}

Bersumber pada pengkajian yang telah diuraikankan di atas dapat di simpulan secara umum ialah, keterlaksanaan model kooperatif tipe Structure Numbered Heads lebih lanjutnya pembelajaran yang dilaksanakan selama satu pertemuan terbilang bagus, 
Vol 2 No 2 Desember 2021

Jurnal AlphaEuclidEdu

Received: 02/02/2021; Resived: 13/09/2021; Accepted: 29/12/2021

kegitan belajar peserta didik pada materi operasi hitung bilangan, pecahan menerapkan model kooperatif tipe Structure Numbered Heads selama satu pertemuan tergolong aktif. Perkembangan hasil belajar siswa pada materi operasi hitung bilangan pecahan di kelas VII MTs. Al-Fathaanah Mempawah Hilir dengan model pembelajaran tipe Structure Numbered Heands tercapai secara klasikal yaitu terdapat 8 pelajar yang meraih KKM (Meraih nilai lebih dari atau sama dengan 75). Namun, masih terdapat 12 peserta didik yang memperoleh nilai dibawah KKM (Meraih nilai lebih dari atau sama dengan 75) yang dalam kegiatan pembelajaran matematika mereka kesulitan untuk mendalami materi yang disanpaikan oleh pengajar.

\section{Saran}

Bersumber pada hasil percobaan di lapangan ketika melakukan percobaan, masukan yang dapat dibagikan dalam percobaan ini adalah sebagai berikut: (1). Pada saat akhir pembelajaran/pertemuan untuk peneliti selanjutnya yang akan menerapkan model pembelajaran Structure Numbered Heads seharusnya diberikan penilaian kemudian dapat melihat hasil belajar atau penguasaan siswa pada setiap pertemuan. (2).Pembelajaran dengan menggubakan model pengajaran Structure Numbered Heads bagi penelaah seterusnya wajib terus berusaha membiasakan kegiatan menggali ilmu peserta didik sehingga semakin bersungguh- sungguh, terutama dibagian kegiatan oral activities, sehingga peserta didik menjadi semakin bersungguh-sungguh dalam mengemukakan pertanyaan dan memberikan pendapat/tanggapan. (3). Pembagian kelompok untuk peneliti berikutnya yang akan menerapkan model pembelajaran Structure Numbered Heads seharusnya memperhatikan tingkat kemampuan peserta didik dan cara statistik. yang sesuai, sehingga dalam satu kelompok anggotanya bisa heterogen ditinjau dari aspek kemampuan peserta didik. (4). Aktivitas belajar peserta didik untuk peneliti berikutnya yang akan menerapkan model pembelajaran Structure Numbered Heads sebaiknya dikenali secara khusus kemudian dapat mengamati transformasi kegiatan peserta didik secara personal.

\section{Referensi}

Hilbert \& Carpenter, T.P. 1992. Learning and teaching with understanding. In D.A Grouws (Ed). Handbook of research on Mathematics teaching and learning. NCTM. New York: Macmilan Publishing Company.

Hardianti, S., Asran, M., \& Syamsiati. (2019). Pengaruh Model Kooperatif Tipe Numbered Heads Together Terhadap Hasil Belajar IPS Kelas V SD. Journal of Chemical Information and Modeling, 53(9), 1-10.

Putra, M., \& Rery, R. U. (n.d.). Penerapan Model Pembelajaran Structured Numbered Heads ( Kepala Bernomor Terstruktur ) Untuk Meningkatkan Prestasi Belajar Peserta Didik Pada Pokok Bahasan Struktur Atom Dan Sistem Periodik Unsur Di Kelas X Mia Sman 5 Pekanbaru Penerapan Model Pembelajara. 1-8.

Putri, T. A. E., Jamiah, Y., \& Sayu, S. (2020). Kemampuan Komunikasi Matematis Siswa Dikaji Dari Self Confidence. Jurnal AlphaEuclidEdu, 1(2), 83. https://doi.org/10.26418/ja.v1i2.42873

Sari, M., Yusmin, E., \& T, A. Y. (2021). Kemampuan representasi matematis siswa pada materi segitiga 1 1,2,3. Jurnal Alpha Euclid Edu, 2(1), 122-128.

Lie, Anita. 2010. Cooperative Learning. Jakarta: PT. Gramedia Widiasarana. 
Vol 2 No 2 Desember 2021

Jurnal AlphaEuclidEdu

Received: 02/02/2021; Resived: 13/09/2021; Accepted: 29/12/2021

Nawawi, H. 2012. Metode Penelitian Bidang Sosial. Yogyakarta: Gajah Mada University Press.

Permendikbud Nomor 104 Tahun 2014 tentang penelitian hasil belajar oleh pendidik pada pendidikan dasar dan pendidikan menengah.

Van de Walle, J. A. 2008. Matematika Sekolah Dasar dan Menengah. Jakarta: Erlangga. 
Vol 2 No 2 Desember 2021

Jurnal AlphaEuclidEdu

Received: 28/09/2021; Resived: 23/11/2021; Accepted: 30/12/2021

\title{
PROSES BERPIKIR SISWA DALAM MEMECAHKAN MASALAH SISTEM PERSAMAAN LINEAR TIGA VARIABEL BERDASARKAN GAYA KOGNITIF DI SMK
}

\author{
Dea Angella, Edy Yusmin, Dian Ahmad \\ Program Studi Pendidikan Matematika, FKIP, Universitas Tanjungpura, Pontianak \\ Email: angelladea44@gmail.com
}

\begin{abstract}
This research aims to thingking process students in cognitive field independent styles in solving mathematical problems in the material three variable linear equation system and to describe the process students in cognitive field dependent styles in solving mathematical problems in thingking material three linear equation. The method used in this research was qualitative descriptive. This research his front used tests, interview and documentation. The test used to determine to cognitive style of each student and the material description of the system of three variable linear equations to determine the thought process. The interview method is used to supplement information. While the docementary is presented in a from that includes photographs during reserach and can be used adevidence that researchers have carried out the research process. The result of thingking of students with cognitive field independent style in solving mathematical problems in material system of linear equations three variable tend to be conceptual, this can be seen from the result of analysis that the subject is able to achieve the indicators of conceptual thingking process, three variable tend to be semiceptual, this can be seen from the result of analysis that most subject are able to achieve the indicators until the completion plan.
\end{abstract}

Keywords : Thinking Process, Cognitive Style, Problem Solving

\section{Pendahuluan}

Penelaahan ilmu hitung berdasarkan PerMenDikBud No. 22 Tahun 2016 sesuai Kurikulum 2013 terdiri dari: (1) menafsirkan rancangan ilmu hitung, menjelaskan implikasi serta menerapakan rancangan secara efektif, patut, teliti, serta cermat dalam menyelesaiakan kesulitan, (2) melakukan demonstrate bawaan dari ilmu hitung, menyalahgunakan ilmu hitung berisi mempersiapkan absreaksi, menentukan alasan, mencari informasi maupun menjelaskan ide serta afirmasi ilmu hitung,(3) mengatasi kesulitan yaitu kepandaian mengatasi kesulitan, menyusun show penyelesaikan ilmu hitung, menyempurnakan demonstrate ilmu hitung, serta menyampaikan pemecahan yang akurat, serta (4) memahami alasan analitis kontruksi bagan, graph, lambang, maupun perangkat lainnya yang mampu memperjelas persoalan maupun bentuknya.

Berdasarkan maksud penelaahan ilmu hitung adalah, mampu meringkas bahwa setelah mengikuti penelaahan ilmu hitung siswa wajib berupaya mengetahui rancangan serta mengaplikasikan rancangan ilmu hitung, melaksanakan penyelewengan ilmu hitung, mengatasi persoalan serta menjabarkan, mengkomunikasikan alasan kedalam kontruksi bagan, graph, representasi, atau perangkat lainnya. Menganalisis ilmu hitung adalah berupa menghitung semata, tetapi murid harus melakukan cara berlogika, berasumsi 
Vol 2 No 2 Desember 2021

Jurnal AlphaEuclidEdu

Received: 28/09/2021; Resived: 23/11/2021; Accepted: 30/12/2021

responsif beserta analitis, mampu mengerjaka kecurangann cabang ilmu hitung, berupaya melakasanakan abstraksi information, mengatasi kesulitan abstraksi cabang ilmu hitung berbeda bersama kesulitan aktivitas intern. Bahwa berasumsi cabang ilmu hitung melambangkan suatu cara berasumsi yang diperoleh murid (Widiyanto et al., 2021).

Berasumsi cabang ilmu hitung menurut Kieran (2004: 149), merupakan cara berasumsi yang melibatkan perkembangan cara berasumsi menggunakan aljabar. Kieran (2004: 141-142) juga menjelaskan bahwa kategori kepandaian berasumsi pada siswa meliputii: (1) kegiatan menggeneralisasi, mengimplikasikan penyusunan aforisme maupun pernyataan serta perbandingan materi ilmu hitung; (2) kegiatan konversi, berasosiasi pada perubahan karkater pernyataan ataupun perbandingan yang berbasis hukum; dan (3) kegiatan kooperatif mengimplikasikan aljabar seperti satu instrument bermanfaat internal menyelesaiakan komplikasi aljabar maupun komplikasi lain.

Berdasarkan hasil tes matematika pada kelas X mengenai materi persaamaan linear tiga variabel, diperoleh data bahwa hanya $72,00 \%$ siswa yang termasuk field dependent dan $27,00 \%$ siswa termasuk field independent dari 32 siswa yang mempunyai kategori tersebut. Dari hasil interview kepada beberapa guru yang berada di sekolah yang membimbing matematika kelas X di SMK Negeri 7 Pontianak pada tanggal 30 Maret 2021, murid invalid menafsirkan model pemecahan persoalan pada pelajaran sistem persamaan linear tiga variabel. Beberapa murid mengalaami kesulitan adalah kesulitan siswa dalam menentukan segala sesuatu yang diketahui dari persoalan dan segala sesuat yang ditanyakan dalam persoalan apa yang diketahui dari nilai yang diketahui pada elastis yang diperoleh atas satu perbandingan, beserta komplikasi analitis mengajukan perkara kontruksi pertanyaan fiksi, dan kesukaran analaitis mengerjakan aktivitas analitis menyempurnakan perbandingan ilmu hitung serupa atas multiplikasi desimal (Panjaitan et al., 2021); (Sulistyowati, 2021).

Apabila berkaitan melalui kepandaian berasumsi cabang ilmu hitung, mengindikassikan kepandaian berasumsi ilmu hitung murid masih kecil, karena masih belum memenuhi indikator berasumsi ilmu hitung. Kepandaian dalam berasumsi didapatkan kepada penelaahan ilmu hitung atas seluruh pelajaran analitis mengatasi kesulitan efektif kesulitan ilmu hitung maupun diluar ilmu hitung yang wajib dikerjakan memerlukan persepsi ilmu hitung, kapabilitas kemahiran berasumsi cabang ilmu hitung sangat penting untuk dikuasai oleh murid (Armiyansyah et al., 2021).

Kepandaian cara berasumsi murid dalam menyelesaikan kesulitan ilmu hitung sesuai dijelaskan kepada pengajar, bahwa pengajar lebih tertarik untuk melaksanakan penelitian tentang kepandaian cara berasumsi siswa dalam mengatasi kesulitan berdasarkan gaya kognitif soal atas pelaajran persamaan linear tiga variabel pada siswa kelas X SMK Negeri 7 Pontianak. Tujuan dari penelitian ini untuk mengetahui kepandaian berasumsi murid dalam mengatasi persoalan yang berasosisasi dengan pengajaran persamaan linear tiga variabel. 
Vol 2 No 2 Desember 2021

Jurnal AlphaEuclidEdu

Received: 28/09/2021; Resived: 23/11/2021; Accepted: 30/12/2021

\section{Metode Penelitian}

Prosedur yang digunakan analitis penelitian ini ialah prosedur deskriptif kualitatif karena pada penelitian ini ialah akan mendeskripsikan kapasitas berasumsi murid beranalitis menyelesaikan persoalan ilmu berdasarkan gaya kognitif analitis mengendalikan komplikasi murid.

Pokok kalimat antobjek penelitian sebanyak empat murid kelas X di SMK Negeri 7 Pontianak yang mempunyai gaya kognitif berbeda- beda, dua orang siswa mempunyai gaya kogintif independent dan dua orang siswa mempunya gaya kognitif dependent, setiap murid mempunyai kemampuannya dalam dirinya.. Pemilihan siswa dilihat dari kemampuan siswa dalam mengatasi kesulitan matematis dari tes geft dan wawancara.

Berikut ini jadwal kegiatan perizinan uji coba, uji coba dan pelaksanaan penelitian tertera pada tabel di bawah ini:

Tabel 1. Jadwal Kegiatan

\begin{tabular}{|c|c|c|c|}
\hline No. & Hari/Tanggal & Kegiatan & Tempat \\
\hline 1 & Kamis, 4 Maret 2021 & $\begin{array}{c}\text { Perizinan Uji Coba } \\
\text { Soal dan Penelitian }\end{array}$ & $\begin{array}{c}\text { SMK Negeri 7 } \\
\text { Pontianak }\end{array}$ \\
\hline 2 & Selasa, 9 Maret 2021 & $\begin{array}{c}\text { Pelaksanaan Uji Coba } \\
\text { Soal }\end{array}$ & $\begin{array}{c}\text { SMK Negeri 7 } \\
\text { Pontianak }\end{array}$ \\
\hline 3 & Jumat, 12 Maret 2021 & Pelaksanaan & SMK Negeri 7 \\
& & Penelitian & Pontianak \\
\hline
\end{tabular}

Metode pengambilan data analitis observasi adalah tes dan non tes (wawancara). Instrumen pengambilan data adalah pertanyaan eksperimen keahlian berasumsi ilmu hitung beserta eksemplar konsultasi. Eksperimen kapasitas berasumsi ilmu hitung terdiri dari empat soal berbentuk esai yang disusun berdasarkan indeks berasumsi ilmu hitung.

\section{Hasil dan Pembahasan}

Hasil

Hasil yang didapatkan oleh penelitian ialah hasil tes kemampuan berpikir geft dalam menyelesaikan soal materi persamaan linear tiga variabel pada empat siswa SMK Negeri 7 Pontianak. Pemberian tes keampuan berpikir geft berupa dua soal pada hari Jum'at, 12 Marer 2021 dengan durasi pengerjaan 40 menit.

Tabel 1. Data Hasil Jawaban Siswa pada Group Embedded Figures Test (GEFT) di Kelas X SMK Negeri 7 Pontianak.

\begin{tabular}{|c|c|}
\hline Jumlah Siswa & Jenis Gaya Kognitif \\
\hline 2 & FD \\
\hline 2 & F1 \\
\hline
\end{tabular}


Vol 2 No 2 Desember 2021

Jurnal AlphaEuclidEdu

Received: 28/09/2021; Resived: 23/11/2021; Accepted: 30/12/2021

Berdasarkan Tabel 1, terlihat bahwa dari enam siswa kelas $\mathrm{X}$ yang mampu menjawab sesuai dengan indikator kemampuan field independent dan field dependent dua siswa, siswa yang menjawab field dependent siswa membutuhkan bantuan guru atau teman sekelas, siswa yang menjawab denga field independent, siswa menyelesaiakn persoalannya sendiri tanpa bantuan teman sekelasnya.

\section{Pembahasan}

Cara belajar mengajar menitik beratkan pada upaya agar materi yang diberikan dapaat dipahami siswa dalam pemebelajaran yang dilakukan oleh guru dengan lebih mudah dapat dipahami oleh siswa yang selanjutnya dapat diterapkan dalam memecahkan persoalan baik yang dirumuskan secara berkelompok maupun persoalan dalam diri sendiri. Demikian, tujuan utama dalam pembelajaran ilmu hitung yaitu kelogisan berasumsi, pendirian tingkah laku murid serta kapasitas analitis implementasi ilmu hitung. Untuk itu, seorang guru harus merancang kegiatan pembelajaran dengan tepat dan mampu memfasilitasi kegiatan belajar siswa di kelas.

Dalam melaksanakan kegiatan di kelas, akan lebih baik jika seorang guru mengetahui cara berpikir dari siswanya. Dengan memahami metode berasumsi murid, guru menerima, melihat kelelahan murid dan mampu mendiskusikan persoalan yang sesuai dengan proses berasumsinya. Selain itu, guru sebaiknya juga mengetahui karkteristik siswanya, salah satunya yaitu perbedaan gaya kognitif murid yang akan mempengaruhi cara penerimaan dan pengolahan informasi yang akan diperoleh.

Dalam penelitian ini, gaya kognitif murid X TBSM dibedakan menjadi dua, yaitu field independent dan field dependent. Murid dengan gaya kognitif field independent cendrung lebih mandiri dalam menyelesaikan persoalan, sedangkan murid dengan gaya field dependent cendrung membutuhkan bantuan dalam menyelesaikan persoalan. Dari tiga puluh dua siswa yang mengikuti tes gaya kognitif terdapat data sebanyak empat murid mempunyai gaya kognitif field independent dan dua puluh dua murid memiliki gaya kognitif field dependent. Dari kuantitas tersebut, peneliti mengambil masing-masing empat murid, penelitian untuk mengetahui cara berasumsi dari masing - masing siswa dalam menyelesaiakan persoalan sistem persamaan linear tiga variabel. Langkah-langkah menyelesaiakan persoalan menurut Polya meliputi memahami masalah, merencanakan penyelesaian, dan mengevaluasi hasil. Adapun metode berasumsi siswa dalam peneltian ini dibedakan menjadi tiga yaitu, abstrak,semikonseptual, dan kamputasional. cara berasumsi abstrak yaitu cara berasumsir yang selalu mengatasi masalah dengan menggunakan langkah yang telah dimiliki berdasarkan hasil pelajarannya. cara bersumsi semikonseptual yaitu cara berasumsi yang cenderung menyelesaiakan suatu soal dengan menggunakan langkah tetapi karena pemahamannya terhadap materi tersebut masih kurang maka penyelesaiannya dicampur dengan menggunakan intuisi. Sedangkan cara berasumsi komputasional yaitu cara berpikir yang pada umumnya menyelesaiakan suatu soal tidak menggunakan langkah tetapi lebih mengandalkan intuisi. 
Vol 2 No 2 Desember 2021

Jurnal AlphaEuclidEdu

Received: 28/09/2021; Resived: 23/11/2021; Accepted: 30/12/2021

\section{Simpulan dan Saran}

\section{Simpulan}

Berdasarkan hasil analisis data, wawancara serta pembahasannya maka dapat disimpulkan secara umum bahwa metode berasumsi siswa analitis menyelesaikan persoalan ilmu hitung berdasarkan gaya kognitif. Adapun kesimpulan yang diperoleh dalam penelitian yang berjudul “ Proses Berpikir Siswa Dalam Memecahkan Masalah Matematika Materi Persamaan Linear Tiga Variabel Berdasarkan Gaya Kognitif di SMK Negeri 7 Pontianak" adalah sebagai berikut: 1) Cara berasumsi murid gaya kognitif field independent, menyelesaiakan persoalan ilmu hitung analitis pelajaran persamaan linear tiga variabel cenderung konseptual, yang dimaksud konseptual ini adalah siswa mampu memahami indikator cara berasumsi konseptualal ini dapat dilihat dari hasil analisis bahwa siswa mampu memenuhi indikator cara berasumsi konseptual. Siswa dengan gaya kognitif field independent memenuhi indikator mampu menyatakan dengan kalimat sendiri apa yang diketahui dan ditanyakan dalam soal atau mengubahnya dalam kalimat ilmu hitung, mampu membuat rencana penyelesaian dengan lengkap, mampu menyatakan langkah-langkah yang ditempuh dalam menyelesaikan soal menggunakan konsep yang telah dipelajari, dn mampu memeriksa kembali kebenaran atau mengoreksi kesalahan dari setiap langkah penyelesaian sehingga diperoleh hasil yang benar; 2) Cara berasumsi murid dengan gaya kognitif field dependent dalam mengerjaka persoalan ilmu hitung pada pelajaran persamaan linear tiga variabel cenderung semikonseptual, hal ini dapat dilihat dari hasil analisis bahwa sebagian besar murid memenuhi indeks cara berasumsi semikonseptual. Murid dengan gaya kognitif field dependent kurang mampu menyatakan dengan kalimat sendiri apa yang diketahui dan ditanyakan dalam soal atau mengubahnya dalam kalimat matematika, mampu membuat rencana penyelesaian namun tidak lengkap, kurang mampu menyatakan langkah-langkah yang ditempuh dalam menyelesaikan ssoal menggunakan konsep yang telah dipelajari, dan kurang mampu memeriksa kembali hasil kerjaannya supaya ada yang benar atau mengoreksi kesalahan dari setiap langkah pengerjaan sehingga diperoleh hasil yang benar.

\section{Saran}

Berdasarkan hasil temuan dalam penelitian ini, saran yang dapat peneliti sampaikan ialah: 1) Guru dapat menggunakan gaya kognitif sebagai patokan dalam membuat alat evaluasi. Dengan memperhatikan proses berpikir siswa berdasarkan gaya kognitif pada tes group embedded firgures test yang berbeda, pendidik dapat memberikan bantuan atau scaffholding yang tepat untuk meningkat respon siswa ke level yang lebih tinggi; 2) Guru bakal lebih sering memberikan siswa pemahaman, bimbingan dan latihan dalam menyelesaikan persoalan cerita agar murid terbiasa memahami persoalan cerita, merancang model matematika dari soal dan merencanakan penyelesaian serta memperoleh solusi yang diharapkan; 3) Guru harus memilih strategi yang membuat siswa tidak sekedar menghapal rumus tetapi juga memahaminya. Untuk penelitian selanjutnya, 
Vol 2 No 2 Desember 2021

Jurnal AlphaEuclidEdu

Received: 28/09/2021; Resived: 23/11/2021; Accepted: 30/12/2021

diharapkan memperhatikan instrumen soal agar lebih baik lagi serta menyempurnakan kekurangan pada penelitian ini.

\section{Referensi}

Ameron, Barbara Ann Van. (2002). Reinvention Of Early Algebra. Tesis. Universiteit Utrech, Nederlands.

Driscoll, M. 1999. Fostering Algebraic Thinking: A Guide for Teachers Grade 610.Portsmouth, NH, Heinemann. Tersedia di www.thetrc.org/trc/download/.../fosteringalg.pdf, [diakses tanggal 5 Juni 2020].

Julie, Ellis. (2004). What's Your Angle, Phytagoras?. (Online). (diakses tanggal 1 Agustus 2020).

Kriegler, S. (2011). "Just What is Algebraic Thingking?. Submitted for Algebraic Concepts in the Middle School."

Kieran, Carolyn. (2004). Algebraic Thinking in the Early Grades: What Is It? The Mathematics Educator. Vol. 8. No. 1.

NCERT, 1961. Algebraic Expressions and Identities. Government of India.

NCTM, 2000. Principles and Standars for School Mathematics. United States of America: The NCTM, Inc.

Armiyansyah, Sugiatno, \& Bistari. (2021). Hambatan siswa dalam belajar matematika dikaji dari kepercayaan matematis 1 1,2,3. Jurnal AlphaEuclidEdu, 2(1), 40-50.

Panjaitan, S., Hartoyo, A., \& Fitriawan, D. (2021). Eksplorasi Etnomatematika Kain Tenun Songket Suku Melayu Sambas. Jurnal AlphaEuclidEdu, 2(1), 19-31. https://jurnal.untan.ac.id/index.php/AlphaEuclidEdu/article/view/47890

Sulistyowati, E. (2021). Pengaruh Penggunaan Model Pembelajaran Kooperatif Tipe Inside Outside Circle ( Ioc ). Jurnal AlphaEuclidEdu, 2(1), 32-40.

Widiyanto, A., Hartoyo, A., \& Nursangaji, A. (2021). Kemampuan berpikir kreatif siswa berdasarkan adversity quotient pada materi dimensi dua 1. Jurnal AlphaEuclidEdu, 2(1), 64-73.

Sudjana, Nana, dan Ibrahim, 1989, Penelitian Kualitatif dan Kuantitatif. Jakarta: Rineka Cipta.

Sukmawati, Ati (2015). Berpikir Aljabar dalam Menyelesaikan Masalah Matematika. Jakarta: Rineka Cipta. 
Vol 2 No 2 Desember 2021

Jurnal AlphaEuclidEdu

Received: 08/09/2021; Resived: 13/10/2021; Accepted: 30/12/2021

\title{
ANALISIS KONSEP MATEMATIKA SEKOLAH DALAM PEMULASARAAN JENAZAH
}

\author{
Tsamara Banafsaj ${ }^{1}$, Ahmad Yani $\mathbf{T}^{2}$, Asep Nursangaji ${ }^{3}$ \\ Program Studi Pendidikan Matematika, FKIP, Universitas Tanjungpura, Pontianak \\ Email: tsamaraasa@gmail.com
}

\begin{abstract}
This research aim to identify the elementary and junior high school mathematic concepts which included the funeral procession. The process of funeral procession that was researched included measuring and cutting the shroud, bathing the corpse, shrouding the corpse, praying the corpse, and burying the corpse. The method of this research is a qualitative, and the form of this research is a literature study. Then the data were collected using documents in the form of books, articles, and notes on the results of the funeral procession by the fardhu kifayah team of Ummu Al-Athiyyah Al-Anshoriyyah. Based on the Miles and Huberman analysis method, elementary and junior high school mathematical concepts are found in the funeral procession, namely rectangles, mixed arithmetic operations, addition, subtraction, multiplication, division, number sequences, sets, linear inequalities of one variable, line segments, vertical lines, horizontal lines, parallel lines, perpendicular lines, point outside the line, 180 degree angel, and cuboids.
\end{abstract}

Keywords: Concept, School Mathematics, Funeral Procession

\section{Pendahuluan}

Matematika sekolah memiliki keterkaitan dengan setiap aktivitas di dalam kehidupan manusia. Karena, salah satu tujuan dari pembelajaran matematika sekolah itu sendiri adalah untuk mempersiapkan siswa agar dapat menggunakan matematika dan pola pikir matematika dalam kehidupan sehari-hari dan dalam berbagai ilmu pengetahuan (Soedjadi, 2000: 43). Pada kenyataannya, keterkaitan matematika sekolah dengan kehidupan manusia tidak hanya terbatas pada hal-hal dunia saja, namun juga dalam hal agama. Dari hasil penelitian Transyah (2018) terungkap bahwa dalam ibadah shalat, ada konsep-konsep matematika yang terkait, antara lain: penjumlahan bilangan cacah, perkalian bilangan cacah, kelipatan dua, himpunan, barisan aritmatika, ruas garis, konsep garis sejajar, dan sudut. Hasil penelitian Puspitasari (2017) terungkap bahwa di dalam sistem hukum waris Islam masyarakat Semudun juga terdapat konsep matematika sekolah yang terkait, yaitu: himpunan, bilangan bulat, operasi penjumlahan bilangan bulat, operasi pengurangan bilangan bulat, operasi perkalian bilangan bulat, operasi pembagian bilangan bulat, operasi pengurangan bilangan pecahan, dan operasi perkalian bilangan pecahan. Termasuk dalam hal agama adalah tentang pemulasaraan jenazah. Banyak orang yang tidak mengetahui bahwa pemulasaraan jenazah juga memiliki keterkaitan dengan konsep matematika sekolah.

Berdasarkan hasil wawancara prariset dengan satu di antara anggota Tim Fardhu Kifayah Ummu Al-Athiyyah Al-Anshoriyyah pada 6 Juli 2020, didapat informasi bahwa terdapat banyak keterkaitan antara matematika sekolah dengan pengurusan (pemulasaraan) jenazah. Sebab dari proses awal ada proses pengukuran, membagi bahan sesuai ukuran yang diperlukan, menggunakan alat ukur panjang secara manual seperti jengkal, memperkirakan berapa lama waktu menjahit kain kafan, mengkafani, dan 
Vol 2 No 2 Desember 2021

Jurnal AlphaEuclidEdu

Received: 08/09/2021; Resived: 13/10/2021; Accepted: 30/12/2021

memandikan agar selesai tepat waktu, dan pada saat memandikan penyiraman air kapur barus harus di angka ganjil terakhir.

Pemulasaraan Jenazah adalah rangkaian prosedur yang harus dilakukan seorang Muslim yang masih hidup yang sudah memenuhi ketentuan untuk melaksanakannya dalam rangka menunaikan hak jenazah. Rangkaian prosedur tersebut secara umum mencakup memandikan, mengafani, mensholatkan, dan memakamkan jenazah. Selain setiap diri diperintahkan untuk mempersiapkan diri dalam menghadapi kematian, juga diperintahkan untuk bisa memulasarakan jenazah sebagai bentuk pemenuhan hak jenazah orang lain. Karena, setiap manusia yang hidup di dunia pasti akan merasakan kematian. Sebagaimana dalam firman Allah, "Segala sesuatu pasti binasa, kecuali Allah." (Q.S. Al-Qashash : 88). Sehingga, tidak menutup kemungkinan bahwa nantinya siswa Muslim akan melaksanakan pemulasaraan jenazah.

Hukum memulasarakan jenazah adalah fardhu kifayah. Artinya, wajib bagi sebagian Muslim untuk mempelajari dan mempraktikkannya, dan jika tidak ada satupun orang dalam suatu kelompok yang mempelajari dan mempraktikkannya maka dapat dikenai dosa. Adanya keterkaitan antara matematika sekolah dengan pemulasaraan jenazah berdasarkan hasil wawancara di atas, menunjukkan bahwa di dalam pemulasaraan jenazah dapat dianalisis lebih lanjut mengenai apa saja konsep matematika sekolah yang terdapat di dalamnya. Sehingga, hasil analisis tersebut dapat dimanfaatkan sebagai contoh kontekstual dalam mengajarkan suatu konsep matematika di sekolah, khususnya sekolah Islam. Dengan mengetahui adanya konsep matematika sekolah tersebut, diharapkan pula dapat mempermudah siswa dalam melaksanakan pemulasaraan jenazah. Berdasarkan penjelasan di atas, peneliti tertarik untuk mengkaji penelitian terkait "Analisis Konsep Matematika Sekolah Dalam Pemulasaraan Jenazah".

\section{Metode Penelitian}

Metode penelitian yang digunakan dalam penelitian ini adalah penelitian kualitatif. Denzin dan Lincoln (dalam Umar Sidiq, 2019) mengemukakan bahwa penelitian kualitatif merupakan penelitian yang menggunakan latar belakang alamiah, dengan maksud menafsirkan fenomena yang terjadi dan dilakukan dengan jalan melibatkan berbagai metode yang ada dalam penelitian kualitatif. Metode yang biasanya dimanfaatkan adalah wawancara, pengamatan, dan pemanfaatan dokumen.

Adapun tujuan penelitian ini adalah untuk mengidentifikasi konsep matematika sekolah dalam pemulasaraan jenazah. Maka bentuk penelitian yang digunakan adalah studi literatur atau penelitian kepustakaan. Menurut Zed (dalam Eka Diah Kartiningrum, 2015), Studi literatur adalah serangkaian kegiatan yang berkenaan dengan metode pengumpulan data pustaka, membaca dan mencatat, serta mengolah bahan penelitian.

Sumber data dalam penelitian ini yaitu Buku Fiqih Jenazah Menurut Al-Qur'an dan As-Sunnah oleh Muhammad Nashiruddin Al-Albani, Buku Shalat Fiqih 4 Madzhab oleh Abdurrahman Al-Jaziri, Buku Kitab Ahkamul Janaiz oleh Abu Fadhli Rabbani, dan catatan hasil pelatihan pemulasaraan jenazah oleh Tim Fardhu Kifayah Al-Athiyyah AlAnshoriyyah, dan beberapa dokumen lainnya yang berkaitan dengan penelitian.

Prosedur penelitian dalam penelitian ini yaitu:

\section{Tahap Persiapan}

Tahap persiapan dalam penelitian ini antara lain (1) Membuat daftar dan mendeskripsikan tata cara memulasarakan jenazah; (2) Membuat daftar dan 
Vol 2 No 2 Desember 2021

Jurnal AlphaEuclidEdu

Received: 08/09/2021; Resived: 13/10/2021; Accepted: 30/12/2021

mendeskripsikan materi matematika sekolah SD/MI dan SMP/MTs; (3) Menyusun desain penelitian; (4) Membuat pedoman dan tabel pengamatan; (5) Seminar desain penelitian.

\section{Tahap Pelaksanaan}

Tahap pelaksanaan dalam penelitian ini berupa (1) Menganalisis konsep matematika sekolah yang terdapat dalam pemulasaraan jenazah; (2) Mengklasifikasikan konsep tersebut berdasarkan ruang lingkup materi; (3) Menyesuaikan konsep yang ditemukan dengan jenjang pendidikan siswa.

\section{Tahap Akhir}

Tahap akhir dalam penelitian ini yaitu (1) Menyusun hasil dan pembahasan berdasarkan hasil analisis data; (2) Membuat kesimpulan dan saran; (3) Menyusun laporan.

\section{Hasil Penelitian dan Pembahsan \\ Hasil Penelitian}

Berdasarkan hasil analisis peneliti, diperoleh data berupa rangkaian dalam pemulasaraan jenazah yang terdapat konsep matematika sekolah di dalamnya, yang secara ringkas dapat dilihat pada beberapa tabel berikut.

Tabel 1. Hasil Penelitian Konsep Matematika Sekolah Dalam Rangkaian Proses Mengukur dan Memotong Kain Kafan

\begin{tabular}{|c|c|c|c|}
\hline No & Kontekstual & Pokok Materi & Konsep Matematika Sekolah \\
\hline 1 & Bentuk Kain Kafan & $\begin{array}{l}\text { Geometri dan } \\
\text { Pengukuran }\end{array}$ & Persegi Panjang \\
\hline 2 & $\begin{array}{c}\text { Pembagian Kain } \\
\text { Kafan }\end{array}$ & Bilangan & $\begin{array}{l}\text { Operasi Hitung Campuran } \\
\text { Bilangan Cacah dan Desimal }\end{array}$ \\
\hline 3 & $\begin{array}{c}\text { Pembuatan Kain } \\
\text { Dasar }\end{array}$ & Bilangan & $\begin{array}{c}\text { Operasi Penjumlahan } \\
\text { Operasi Pengurangan } \\
\text { Operasi Perkalian } \\
\text { Operasi Pembagian } \\
\text { Operasi Hitung Campuran }\end{array}$ \\
\hline 4 & Pembuatan 7 utas tali & Bilangan & $\begin{array}{l}\text { Operasi Pembagian } \\
\text { Operasi Penjumlahan }\end{array}$ \\
\hline
\end{tabular}

Berdasarkan tabel 1, konsep matematika sekolah yang terdapat dalam rangkaian mengukur dan memotong kain kafan yaitu pada pokok materi Bilangan dan Geometri. Dalam pokok materi Bilangan, konsep matematika sekolah yang terkandung yaitu: (1) Operasi Hitung campuran; (2) Operasi penjumlahan; (3) Operasi Pengurangan; (4) Operasi Perkalian; dan (5) Operasi Pembagian. Sedangkan dalam pokok materi Geometri terdapat konsep persegi panjang.

Tabel 2. Hasil Penelitian Konsep Matematika Sekolah Dalam Rangkaian Proses Memandikan Jenazah

\begin{tabular}{|l|c|c|c|}
\hline No & Kontekstual & Pokok Materi & Konsep Matematika Sekolah \\
\hline
\end{tabular}


Vol 2 No 2 Desember 2021

Jurnal AlphaEuclidEdu

Received: 08/09/2021; Resived: 13/10/2021; Accepted: 30/12/2021

\begin{tabular}{|c|l|c|c|}
\hline $\mathbf{1}$ & $\begin{array}{l}\text { Banyaknya proses } \\
\text { memandikan jenazah }\end{array}$ & Bilangan & Barisan Bilangan \\
\hline $\mathbf{2}$ & $\begin{array}{l}\text { Banyaknya proses } \\
\text { memandikan jenazah } \\
\text { dengan air larutan sabun } \\
\text { atau daun bidara }\end{array}$ & Bilangan & Barisan Aritmatika \\
\hline $\mathbf{3}$ & $\begin{array}{l}\text { Waktu untuk memandikan } \\
\text { jenazah dengan air larutan } \\
\text { kamper }\end{array}$ & Bilangan & Barisan Bilangan \\
\hline
\end{tabular}

Berdasarkan tabel 2, konsep matematika sekolah yang terdapat dalam rangkaian memandikan jenazah yaitu terdapat pada pokok materi Bilangan saja, dengan konsep matematika barisan bilangan dan barisan aritmatika.

Tabel 3. Hasil Penelitian Konsep Matematika Sekolah Dalam Rangkaian Proses Mengafani Jenazah

\begin{tabular}{|c|c|c|c|}
\hline No & Kontekstual & Pokok Materi & Konsep Matematika Sekolah \\
\hline 1 & $\begin{array}{lr}\text { Banyaknya lapisan } \\
\text { kain kafan } \\
\text { jenazah }\end{array}$ & Bilangan & Operasi Penjumlahan \\
\hline
\end{tabular}

Berdasarkan tabel 3, konsep matematika sekolah yang terdapat dalam rangkaian mengafani jenazah yaitu pada pokok materi Bilangan, dengan konsep operasi penjumlahan.

Tabel 4. Hasil Penelitian Konsep Matematika Sekolah Dalam Rangkaian Proses Menshalatkan Jenazah

\begin{tabular}{|c|l|c|ll|}
\hline No & \multicolumn{1}{|c|}{ Kontekstual } & Pokok Materi & \multicolumn{1}{|l|}{ Konsep Matematika Sekolah } \\
\hline $\mathbf{1}$ & $\begin{array}{l}\text { Jumlah minimal dan } \\
\text { maksimal jama'ah } \\
\text { shalat jenazah }\end{array}$ & Aljabar & $\begin{array}{l}\text { Himpunan } \\
\text { Pertidaksamaan Linear Satu } \\
\text { Variabel }\end{array}$ \\
\hline $\mathbf{2}$ & $\begin{array}{l}\text { Jumlah barisan jama'ah } \\
\text { shalat jenazah }\end{array}$ & Aljabar & $\begin{array}{l}\text { Himpunan } \\
\text { Pertidaksamaan Linear Satu } \\
\text { Variabel }\end{array}$ \\
\hline $\mathbf{3}$ & $\begin{array}{l}\text { Posisi barisan shalat } \\
\text { jenazah }\end{array}$ & $\begin{array}{l}\text { Geometri dan } \\
\text { Pengukuran }\end{array}$ & $\begin{array}{l}\text { Ruas Garis } \\
\text { Garis Sejajar }\end{array}$ \\
\hline $\mathbf{4}$ & $\begin{array}{l}\text { Jumlah takbir dalam } \\
\text { shalat jenazah }\end{array}$ & Bilangan & Operasi Perkalian \\
\hline $\mathbf{5}$ & $\begin{array}{l}\text { Posisi berdiri imam } \\
\text { terhadap jenazah laki- } \\
\text { laki dan perempuan }\end{array}$ & $\begin{array}{l}\text { Geometri dan } \\
\text { Pengukuran }\end{array}$ & Titik di Luar Garis \\
\hline $\mathbf{6}$ & $\begin{array}{l}\text { Posisi berdiri seseorang } \\
\text { dalam shalat jenazah } \\
\text { terhadap jenazah }\end{array}$ & $\begin{array}{l}\text { Geometridan } \\
\text { Pengukuran }\end{array}$ & $\begin{array}{l}\text { Ruas Garis } \\
\text { Garis Vertikal } \\
\text { Garis Horizontal } \\
\text { Garis Tegak Lurus }\end{array}$ \\
\hline
\end{tabular}


Vol 2 No 2 Desember 2021

Jurnal AlphaEuclidEdu

Received: 08/09/2021; Resived: 13/10/2021; Accepted: 30/12/2021

\begin{tabular}{|l|l|l|}
\hline & & Sudut $180^{\circ}$ \\
\hline
\end{tabular}

Berdasarkan tabel 4, konsep matematika sekolah yang terdapat dalam rangkaian menshalatkan jenazah yaitu terdapat pada pokok materi Bilangan, Aljabar dan Geometri. Dalam pokok materi Bilangan, konsep matematika sekolah yang terkandung yaitu operasi perkalian. Kemudian dalam pokok materi Aljabar, terdapat konsep: (1) Himpunan dan (2) Pertidaksamaan linear satu variabel. Sedangkan dalam pokok materi Geometri terdapat konsep: (1) Ruas Garis; (2) Garis sejajar; (3) Titik di luar garis; (4) Garis tegak lurus; (5) Garis Vertikal; (6) Garis Horizontal; dan (7) Sudut $180^{\circ}$.

Tabel 5. Hasil Penelitian Konsep Matematika Sekolah Dalam Rangkaian Proses Memakamkan Jenazah

\begin{tabular}{|c|c|c|c|}
\hline No & Kontekstual & Pokok Materi & Konsep Matematika Sekolah \\
\hline $\mathbf{1}$ & Bentuk lubang kubur & $\begin{array}{c}\text { Geometri dan } \\
\text { Pengukuran }\end{array}$ & Balok \\
\hline
\end{tabular}

Berdasarkan tabel 5, konsep matematika sekolah yang terdapat dalam rangkaian memakamkan jenazah yaitu terdapat pada pokok materi Geometri saja, dengan konsep matematika balok.

\section{Pembahasan \\ Mengukur dan Memotong Kain Kafan \\ Bentuk Kain Kafan}

Kain kafan yang digunakan adalah kain yang memiliki bentuk menyerupai bangun datar persegi panjang ketika dihamparkan. Kain tersebut memiliki ciri-ciri yang sangat mendekati ciri-ciri bangun datar persegi panjang, yaitu memiliki dua pasang sisi yang masing-masing sama panjang dan sejajar dengan pasangannya. Selain itu, kain kafan memiliki ciri yang sama dengan persegi panjang dalam hal sudut, yaitu keempat sudutnya berbentuk siku-siku karena sisi panjang dan sisi lebarnya saling berpotongan tegak lurus. Pada pembahasan ini, sisi panjang kain adalah sisi yang bersesuaian dengan tinggi badan jenazah, dan sisi lebar kain adalah sisi yang bersesuaian dengan lebar badan jenazah.

\section{Pembagian Kain Kafan}

Pada pembagian kain kafan, terkandung operasi hitung campuran. Operasi hitung campuran yang dimaksud adalah operasi perkalian bilangan cacah dan penjumlahan bilangan cacah dan desimal. Konsep-konsep ini saling berhubungan satu sama lain.

Konsep operasi penjumlahan terdapat pada panjang setiap pola yang jika dijumlahkan akan setara dengan panjang kain utuh. Namun, satuan panjang pola yang disajikan tidak semuanya sama. Padahal, panjang setiap pola dapat dijumlahkan jika satuannya sama. Panjang pola ada yang dinyatakan dalam satuan meter dan ada pula yang dinyatakan dalam satuan sentimeter, sedangkan panjang kain kafan utuh dinyatakan dalam satuan meter. Oleh karena itu, untuk dapat menjumlahkan panjang setiap pola, maka satuan panjang masing-masing pola dikonversi terlebih dahulu ke dalam meter, yang kemudian disesuaikan dengan panjang kain utuh dalam satuan meter.

Dalam tangga satuan panjang, untuk mengonversi suatu satuan panjang ke suatu satuan panjang lain yang tingkatnya lebih bawah, maka setiap satu kali melangkah ke 
Vol 2 No 2 Desember 2021

Jurnal AlphaEuclidEdu

Received: 08/09/2021; Resived: 13/10/2021; Accepted: 30/12/2021

bawah, ia dikalikan dengan 10. Sedangkan untuk mengonversi suatu satuan panjang ke suatu satuan panjang lainnya yang tingkatnya lebih atas ia dibagi dengan 10 . Untuk mengonversi sentimeter ke meter memerlukan dua kali naik tangga. Maka, $1 \mathrm{~cm}=((1$ : 10) : 10) $\mathrm{m}=0.01 \mathrm{~m}$.

Pada proses pembagian kain kafan, kain dipotong pada sisi panjang kain atau pola pemotongannya sejajar dengan sisi lebar kain. Misal panjang kain utuh adalah x meter dan panjang masing-masing polanya adalah a meter yang dibuat sebanyak 5 lembar, $\mathrm{b}$ meter, dan $\mathrm{c}$ meter. Maka, $\mathrm{x}$ meter $=5 \times$ a meter $+\mathrm{b}$ meter $+\mathrm{c}$ meter. Perhitungan ini mengandung konsep operasi perkalian dan penjumlahan. Sebuah perkalian bilangan $a \times b$ diartikan sebagai penjumlahan bilangan $b$ sebanyak a kali.

Jadi, $a \times b=b+\underbrace{b+b+\ldots+b}$

Sebanyak a kali

Konsep hubungan antar satuan panjang serta operasi hitung campuran pada pembagian kain kafan disajikan dalam tabel berikut ini.

Tabel 6. Konsep Operasi Hitung Campuran Bilangan Cacah dan Desimal

\begin{tabular}{|c|c|c|c|}
\hline No & Panjang Kain Utuh & $\begin{array}{c}\text { Panjang Pola Setelah } \\
\text { Dikonversi }\end{array}$ & $\begin{array}{c}\text { Operasi Hitung } \\
\text { Campuran Bilangan } \\
\text { Cacah dan Desimal }\end{array}$ \\
\hline \multirow[t]{3}{*}{1} & $\begin{array}{ll}\text { Kain kafan } & \text { untuk } \\
\text { jenazah laki-laki } & \end{array}$ & & \\
\hline & $\begin{array}{l}\text { Kain bahan Mori } \\
\text { panjang } 13 \mathrm{~m}\end{array}$ & $\begin{array}{l}\text { Bahan kain dasar } 2.5 \\
\text { m sebanyak } 5 \text { lembar, } \\
\text { cawat } 0.5 \mathrm{~m}\end{array}$ & $\begin{array}{l}5 \times 2.5+0.5=(2.5+2.5+ \\
2.5+2.5+2.5)+0.5=12.5 \\
+0.5=13\end{array}$ \\
\hline & $\begin{array}{l}\text { Kain bahan Drill panjang } \\
7.5 \mathrm{~m}\end{array}$ & $\begin{array}{l}\text { Bahan kain dasar } 2.5 \\
\text { m sebanyak } 3 \text { lembar }\end{array}$ & $\begin{array}{l}3 \times 2.5=2.5+2.5+2.5= \\
7.5\end{array}$ \\
\hline \multirow[t]{4}{*}{2} & $\begin{array}{l}\text { Kain kafan untuk } \\
\text { jenazah perempuan }\end{array}$ & & \\
\hline & $\begin{array}{l}\text { Kain bahan Mori } \\
\text { panjang } 13 \mathrm{~m}\end{array}$ & $\begin{array}{l}\text { Bahan kain dasar } 2.5 \\
\text { m sebanyak } 3 \text { lembar, } \\
\text { jilbab } 0.9 \mathrm{~m} \text {, sarung } \\
1.5 \mathrm{~m} \text {, jubah } 2.5 \mathrm{~m} \text {, } \\
\text { cawat } 0.6 \mathrm{~m}\end{array}$ & $\begin{array}{l}3 \times 2.5+0.9+1.5+2.5+ \\
0.6=(2.5+2.5+2.5)+0.9 \\
+1.5+2.5+0.6=7.5+0.9 \\
+1.5+2.5+0.6=13\end{array}$ \\
\hline & $\begin{array}{l}\text { Kain kafan bahan Mori } \\
\text { panjang } 15 \mathrm{~m}\end{array}$ & $\begin{array}{l}\text { Bahan kain dasar } 2.5 \\
\text { m sebanyak } 4 \text { lembar, } \\
\text { jilbab } 0.9 \mathrm{~m} \text {, sarung } \\
1.5 \mathrm{~m} \text {, jubah } 2 \mathrm{~m} \text {, } \\
\text { cawat } 0.6 \mathrm{~m}\end{array}$ & $\begin{array}{l}4 \times 2.5+0.9+1.5+2+0.6 \\
=(2.5+2.5+2.5+2.5)+ \\
0.9+1.5+2+0.6=10+ \\
0.9+1.5+2+0.6=15\end{array}$ \\
\hline & $\begin{array}{l}\text { Kain kafan bahan Mori } \\
\text { panjang } 16 \mathrm{~m}\end{array}$ & $\begin{array}{l}\text { Bahan kain dasar } 2.5 \\
\text { m sebanyak } 4 \text { lembar, } \\
\text { jilbab } 0.9 \mathrm{~m} \text {, sarung } \\
1.5 \mathrm{~m} \text {, jubah } 2.5 \mathrm{~m} \text {, } \\
\text { cawat } 0.6 \mathrm{~m} \text {, waslap }\end{array}$ & $\begin{array}{l}4 \times 2.5+0.9+1.5+2.5+ \\
0.6+0.5=(2.5+2.5+2.5 \\
+2.5)+0.9+1.5+2.5+ \\
0.6+0.5=10+0.9+1.5+ \\
2+0.6+0.5=16\end{array}$ \\
\hline
\end{tabular}


Vol 2 No 2 Desember 2021

Jurnal AlphaEuclidEdu

Received: 08/09/2021; Resived: 13/10/2021; Accepted: 30/12/2021

\begin{tabular}{|c|c|c|}
\hline & $0.5 \mathrm{~cm}$ & \\
\hline $\begin{array}{l}\text { Kain kafan bahan Drill } \\
\text { panjang } 10 \mathrm{~m}\end{array}$ & $\begin{array}{l}\text { Bahan kain dasar } 2.5 \\
\text { m sebanyak } 2 \text { lembar, } \\
\text { jilbab } 1.5 \mathrm{~m} \text {, sarung } \\
1.5 \mathrm{~m} \text {, jubah } 2 \mathrm{~m} .\end{array}$ & $\begin{array}{l}2 \times 2.5+1.5+1.5+2= \\
(2.5+2.5)+1.5+1.5+2= \\
5+1.5+1.5+2=10\end{array}$ \\
\hline
\end{tabular}

\section{Pembuatan Kain Dasar}

Pada rangkaian ini, terkandung konsep operasi pembagian, operasi penjumlahan, operasi pengurangan, dan operasi hitung campuran. Konsepnya terdapat pada cara pembuatan kain dasar dari bahan yang disiapkan sehingga sisi lebar dari kain dapat cukup menutupi lebar tubuh jenazah. Sedangkan pada sisi panjang dari kain tidak dilakukan pemotongan. Adapun kebutuhan kain dasar jenazah yaitu laki-laki 3 lembar dan perempuan 2 lembar, sehingga hasil akhir dari setiap bahan kain dasar yang dipotong dan dijahit adalah terbentuk 3 lembar kain dasar untuk jenazah laki-laki, dan 2 lembar kain dasar untuk jenazah perempuan. Pembahasannya adalah sebagaimana dalam tabel berikut.

Tabel 7. Konsep Matematika Sekolah Dalam Pembuatan Kain Dasar

\begin{tabular}{|c|c|c|c|}
\hline No & $\begin{array}{l}\text { Jenis dan } \\
\text { Ukuran } \\
\text { Kain Kafan }\end{array}$ & Langkah-langkah & $\begin{array}{c}\text { Konsep } \\
\text { Matematika } \\
\text { Sekolah }\end{array}$ \\
\hline & $\begin{array}{l}\text { Kain kafan untuk } \\
\text { jenazah laki-laki }\end{array}$ & & \\
\hline \multirow[t]{4}{*}{1} & \multirow[t]{4}{*}{$\begin{array}{l}\text { Bahan } \quad \text { Mori } \\
\text { ukuran } 13 \mathrm{~m} \times 90 \\
\mathrm{~cm}\end{array}$} & $\begin{array}{l}\text { Lembar-1 bahan kain dasar dibagi } \\
\text { menjadi } 2 \text { bagian sama besar, dengan } \\
\text { arah pemotongan sejajar sisi panjang. } \\
\text { Artinya, sisi lebar dibagi } 2 \text {. }\end{array}$ & $90 \mathrm{~cm}: 2=45 \mathrm{~cm}$ \\
\hline & & $\begin{array}{l}\text { Hasil potongan tersebut masing- } \\
\text { masing disatukan dengan lembar-2 } \\
\text { dan } 3 \text { bahan kain dasar, dengan cara } \\
\text { dipertemukan sisi-sisi lebarnya. } \\
\text { Artinya, sisi lebar bertambah. }\end{array}$ & $\begin{array}{l}90 \mathrm{~cm}+45 \mathrm{~cm}= \\
135 \mathrm{~cm}\end{array}$ \\
\hline & & $\begin{array}{l}\text { Lembar-4 dan } 5 \text { masing-masing } \\
\text { dipotong selebar } 2 \text { kali } 3 \text { jari tangan } \\
\text { untuk dibuat menjadi tali, dengan } \\
\text { arah pemotongan sejajar dengan sisi } \\
\text { panjang. Lebar } 3 \text { jari tangan } \\
\text { dianggap } 5 \mathrm{~cm} \text {. Artinya, sisi lebar } \\
\text { kain berkurang. }\end{array}$ & $\begin{array}{l}90 \mathrm{~cm}-(2 \times 5 \mathrm{~cm})= \\
90 \mathrm{~cm}-(5 \mathrm{~cm}+5 \\
\mathrm{cm})=90 \mathrm{~cm}-10 \\
\mathrm{~cm}=80 \mathrm{~cm}\end{array}$ \\
\hline & & $\begin{array}{l}\text { Hasil potongan tersebut disatukan, } \\
\text { dengan cara dipertemukan sisi-sisi } \\
\text { lebarnya. Artinya, sisi lebar } \\
\text { bertambah. }\end{array}$ & $\begin{array}{l}80 \mathrm{~cm}+80 \mathrm{~cm}= \\
160 \mathrm{~cm}\end{array}$ \\
\hline 2 & 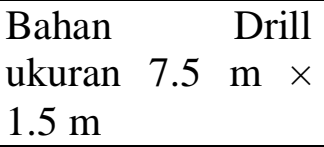 & $\begin{array}{l}\text { Lembar-1 dipotong selebar } 2 \text { kali } 3 \\
\text { jari tangan untuk dibuat menjadi tali, } \\
\text { dengan arah pemotongan sejajar }\end{array}$ & $\begin{array}{l}1.5 \mathrm{~m}-(2 \times 5 \mathrm{~cm})= \\
1.5 \mathrm{~m}-(5 \mathrm{~cm}+5 \\
\mathrm{cm})=1.5 \mathrm{~m}-10 \mathrm{~cm}\end{array}$ \\
\hline
\end{tabular}


Vol 2 No 2 Desember 2021

Jurnal AlphaEuclidEdu

Received: 08/09/2021; Resived: 13/10/2021; Accepted: 30/12/2021

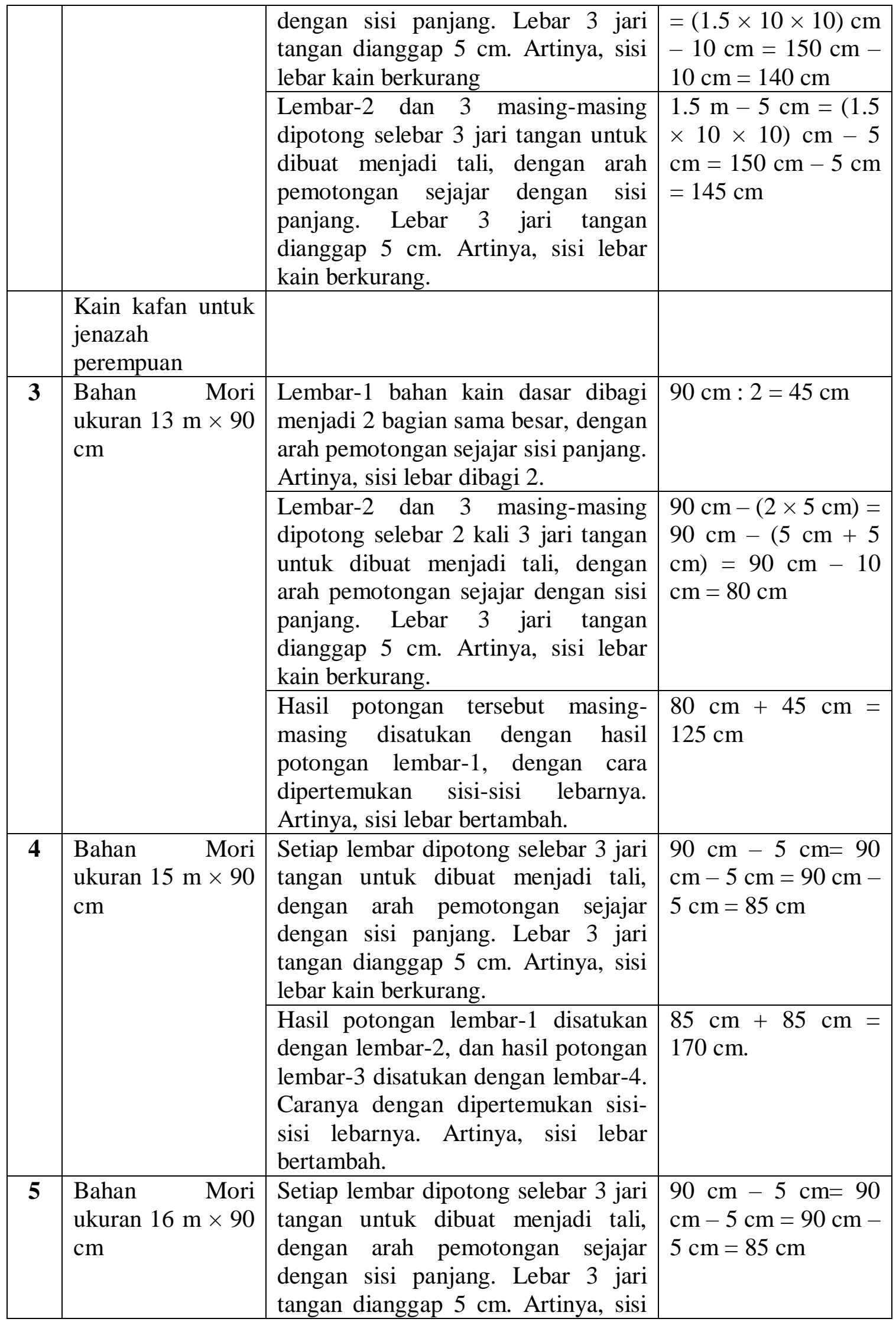


Vol 2 No 2 Desember 2021

Jurnal AlphaEuclidEdu

Received: 08/09/2021; Resived: 13/10/2021; Accepted: 30/12/2021

\begin{tabular}{|c|c|c|c|}
\hline & & lebar kain berkurang. & \\
\hline & & $\begin{array}{l}\text { Hasil potongan lembar-1 disatukan } \\
\text { dengan lembar-2, dan hasil potongan } \\
\text { lembar-3 disatukan dengan lembar-4. } \\
\text { Caranya dengan dipertemukan sisi- } \\
\text { sisi lebarnya. Artinya, sisi lebar } \\
\text { bertambah. }\end{array}$ & $\begin{array}{l}85 \mathrm{~cm}+85 \mathrm{~cm}= \\
170 \mathrm{~cm} .\end{array}$ \\
\hline
\end{tabular}

\section{Pembuatan 7 Utas Tali}

Tujuh utas tali dibuat dari hasil melipat dan memotong empat utas tali utuh sesuai bagian-bagian tali yang dibutuhkan untuk mengikat tubuh jenazah. Pembuatan 7 utas tali dijelaskan sebagai berikut.

Utasan-1 dibiarkan utuh, artinya melambangkan bilangan

Utasan-2 dipotong menjadi 2 bagian sama panjang, artinya melambangkan bilangan $\frac{1}{2}$ dan $\frac{1}{2}$.

Utasan-3 dipotong menjadi 2 bagian, bagian pertama sepanjang $\frac{3}{4}$ dari panjang utasan-3 dan bagian kedua sepanjang $\frac{1}{4}$ dari panjang utasan-3, artinya melambangkan bilangan $\frac{3}{4}$ dan $\frac{1}{4}$

Utasan-4 dipotong menjadi 2 bagian, bagian pertama sepanjang $\frac{3}{4}$ dari panjang utasan- 4 dan bagian kedua sepanjang $\frac{1}{4}$ dari panjang utasan-4, artinya melambangkan bilangan $\frac{3}{4}$ $\operatorname{dan} \frac{1}{4}$

Pembuatan 7 utas tali tersebut sesuai dengan konsep pembagian, lebih khususnya yaitu pembagian dengan pembagi bilangan dua. Dua bagian sama panjang diperoleh dengan membagi 1 dengan 2 . Untuk $\frac{3}{4}$ dan $\frac{1}{4}$, diperoleh dengan dua tahap, yaitu membagi 1 dengan 2, kemudian membagi hasil baginya dengan 2 .

Selain itu, rangkaian ini mengandung konsep operasi penjumlahan bilangan cacah dan pecahan pada jumlah panjang 7 utas tali sehingga terbukti benar ketujuhnya berasal dari 4 utas tali. Ketujuh bilangan tersebut jika dijumlahkan hasilnya adalah 4.

$$
\begin{aligned}
1+\frac{1}{2}+\frac{1}{2} & +\frac{3}{4}+\frac{1}{4}+\frac{3}{4}+\frac{1}{4}=\frac{4}{4}+\frac{2}{4}+\frac{2}{4}+\frac{3}{4}+\frac{1}{4}+\frac{3}{4}+\frac{1}{4} \\
& =\frac{(4+2+2+3+1+3+1)}{4} \\
& =\frac{16}{4} \\
& =4
\end{aligned}
$$

\section{Memandikan Jenazah}

\section{Banyaknya Proses Memandikan Jenazah}

Berdasarkan hadits riwayat Al-Bukhori dan Muslim, Rasulullah bersabda:

"Mandikan dia sebanyak tiga kali atau lima kali atau tujuh kali atau lebih banyak dari itu, jika kalian memandangnya perlu, dengan air dan daun bidara." Ummu "Athiyah bertanya, "Dalam bilangan ganjil?" Beliau menjawab, "Iya! Dan 
Vol 2 No 2 Desember 2021

Jurnal AlphaEuclidEdu

Received: 08/09/2021; Resived: 13/10/2021; Accepted: 30/12/2021

campurkanlah airnya dengan tumbuhan kafur (kapur barus) atau sedikit darinya di akhir siraman!".

Dari hadits tersebut terdapat beberapa bilangan yang jika diurutkan menjadi: 3, 5, 7, sampai dengan tak dibatasi jumlah maksimalnya. Bilangan-bilangan tersebut membentuk konsep pola tertentu yang dikenal dengan sebutan barisan bilangan. Adapun barisan yang dibentuk adalah barisan bilangan ganjil lebih dari sama dengan 3 pada jumlah proses memandikan jenazah, yaitu $3,5,7, \ldots$.

\section{Banyaknya Proses Memandikan Jenazah Dengan Air Larutan Sabun Atau Daun Bidara}

Ketika jenazah sudah dimandikan dengan air larutan sabun atau daun bidara sebanyak 2 kali namun jenazah masih belum bersih, maka jenazah kembali dimandikan sebanyak 2 kali pemandian dengan air larutan sabun atau daun bidara sehingga jumlah total memandikan saat ini adalah 4 kali. Namun jika jenazah masih belum bersih, jenazah kembali dimandikan sebanyak 2 kali pemandian dengan air larutan sabun atau daun bidara sehingga jumlah total memandikan saat ini adalah 6 kali. Begitu seterusnya.

Hal ini sesuai dengan konsep barisan aritmatika. Karena, barisan bilangan yang terbentuk suku-sukunya berurutan, dan setiap bilangan memiliki nilai selisih atau nilai beda yang tetap.

Jumlah proses memandikan jenazah dengan air larutan sabun atau daun bidara dilakukan sebanyak 2, 4, 6, .., n kali pada setiap dua kali pemandian. Artinya, ketika dua pemandian pertama, jenazah dimandikan dengan air larutan sabun atau daun bidara sebanyak dua kali. Ketika dua pemandian kedua jenazah dimandikan dengan air larutan sabun atau daun bidara sebanyak empat kali, Ketika dua pemandian ketiga jenazah dimandikan dengan air larutan sabun atau daun bidara sebanyak enam kali. Dan seterusnya.

Jumlah pemandian dengan air larutan sabun atau daun bidara pada setiap dua pemandian ke-n yaitu:

$$
\begin{gathered}
\mathrm{U}_{1}=a \\
\mathrm{U}_{2}=a+b \\
\mathrm{U}_{3}=a+2 b \\
\mathrm{U}_{\mathrm{n}}=a+(n-1) b
\end{gathered}
$$

\section{Waktu Untuk Memandikan Jenazah Dengan Air Larutan Kamper}

Berdasarkan hadits riwayat Al-Bukhori dan Muslim, Rasulullah bersabda: "Mandikan dia sebanyak tiga kali atau lima kali atau tujuh kali atau lebih banyak dari itu, jika kalian memandangnya perlu, dengan air dan daun bidara."

Ummu 'Athiyah bertanya, "Dalam bilangan ganjil?" Beliau menjawab, "Iya! Dan campurkanlah airnya dengan tumbuhan kafur (kapur barus) atau sedikit darinya di akhir siraman!'”.

Dan berdasarkan (Al Jaziri, 2017) bahwa di akhir pemandian, jenazah dimandikan dengan air larutan kamper atau wewangian lainnya. Dari dua hal di atas, maka pemandian dengan air larutan kamper dilakukan satu kali pada pemandian yang terakhir. Yaitu pada pemandian ke-3, ke-5, ke-7, dan seterusnya. Hal ini sesuai dengan konsep barisan bilangan. Adapun barisan yang dibentuk adalah barisan bilangan ganjil lebih dari sama dengan 3 , yaitu: $3,5,7, \ldots$. 
Vol 2 No 2 Desember 2021

Jurnal AlphaEuclidEdu

Received: 08/09/2021; Resived: 13/10/2021; Accepted: 30/12/2021

\section{Mengafani Jenazah}

\section{Banyaknya Lapisan Kain Kafan Pada Jenazah}

Berdasarkan Al-Jaziri (2019: 664-665), jenazah laki-laki dikafankan dengan tiga lapis kain. Sedangkan jenazah perempuan dikafankan dengan 5 lapis kain. Menurut Vera (2020) tiga lapis kain pada jenazah laki-laki itu terdiri dari 3 lembar kain dasar. Sedangkan pada jenazah perempuan, 5 lapis kain terdiri dari 2 lembar kain dasar, 1 lembar kain jilbab, 1 lembar kain jubah, dan 1 lembar kain sarung.

Banyaknya lapisan kain kafan pada jenazah mengandung konsep operasi penjumlahan sebagai berikut.

Tabel 8. Konsep Operasi Penjumlahan Bilangan Cacah Pada Banyaknya Lapisan Kain Kafan Pada Jenazah

\begin{tabular}{|l|l|c|}
\hline No & \multicolumn{1}{|c|}{$\begin{array}{c}\text { Banyaknya Lapisan Kain Kafan Pada } \\
\text { Jenazah }\end{array}$} & \multicolumn{1}{|c|}{$\begin{array}{c}\text { Penjumlahan Bilangan } \\
\text { Cacah }\end{array}$} \\
\hline $\mathbf{1}$ & $\begin{array}{l}\text { Jenazah laki-laki dikafani dengan 3 lapis } \\
\text { kain kafan }\end{array}$ & $1+1+1=3$ \\
\hline $\mathbf{2}$ & $\begin{array}{l}\text { Jenazah perempuan dikafani dengan 5 lapis } \\
\text { kain kafan }\end{array}$ & $2+1+1+1=5$ \\
\hline
\end{tabular}

\section{Menshalatkan Jenazah}

\section{Jumlah Minimal dan Maksimal Jama'ah Shalat Jenazah}

Dalam kasus umum, jumlah minimal jama'ah atau orang yang shalat jenazah di belakang imam adalah 3 orang. Adapun jumlah maksimal jama'ah adalah tidak dibatasi.

Hal ini sesuai dengan konsep pertidaksamaan linear satu variabel $\mathrm{x} \geq 3$, yaitu apabila akan dilaksanakan shalat jenazah, maka jumlah jama'ah yang harus hadir adalah minimal 3 orang, dengan x dimisalkan sebagai jumlah jama'ah.

Selain itu, konsep matematika yang terkandung di dalamnya adalah himpunan, yaitu himpunan jama'ah yang hadir untuk melaksanakan shalat jenazah. Ini sejalan dengan himpunan bilangan asli yang lebih atau sama dengan 3. Misalkan $\mathrm{H}$ adalah himpunannya, maka $H=\{x \mid x \geq 3, x$ adalah bilangan cacah $\}=\{3,4,5,6, \ldots\}$.

\section{Jumlah Barisan Jama'ah Shalat Jenazah}

Berdasarkan perkataan Nashiruddin Al-Albani, dalam shalat jenazah disunnahkan membuat tiga barisan atau lebih. Perkataan beliau ini sesuai dengan hadits riwayat AthThabrani, dari Abu Umamah ia berkata,

"Rasulullah pernah menshalatkan jenazah bersama tujuh orang jama'ah. Beliau menjadikan tiga orang dalam satu barisan (pertama), diikuti dua orang pada satu barisan (kedua), serta dua orang lain dalam satu barisan (ketiga)."

Hal ini sesuai dengan pertidaksamaan linear satu variabel $\mathrm{x} \geq 3$, yaitu apabila akan dilaksanakan shalat jenazah, jama'ah disunnahkan membentuk minimal tiga barisan atau lebih.

Selain itu, terdapat pula konsep himpunan, yaitu himpunan barisan jama'ah dalam shalat jenazah. Ini sejalan dengan himpunan bilangan asli yang lebih atau sama dengan 3. Misalkan $\mathrm{H}$ adalah himpunannya, maka $\mathrm{H}=\{\mathrm{x} \mid \mathrm{x} \geq 3$, $\mathrm{x}$ adalah bilangan cacah $\}=$ $\{3,4,5,6, \ldots\}$.

Hadits riwayat Ath-thabrani di atas kemudian dijelaskan alasannya mengapa 7 orang jama'ah dapat membentuk 3 barisan, dengan perkataan Al-Qadhi Ali bin 
Vol 2 No 2 Desember 2021

Jurnal AlphaEuclidEdu

Received: 08/09/2021; Resived: 13/10/2021; Accepted: 30/12/2021

Muhammad bin Ali Asy-Syaukai dalam kitab Nailul Authar, beliau berkata bahwa batas sebuah barisan disebut shaf adalah setiap barisnya minimal terdiri dari dua orang dan tidak ada batas maksimalnya.

Hal ini sesuai dengan konsep pertidaksamaan linear satu variabel $\mathrm{x} \geq 2$, yaitu apabila akan dilaksanakan shalat jenazah, jumlah jama'ah pada setiap barisan adalah minimal 2 orang.

Maka dalam kasus umum yaitu jumlah orang yang hadir untuk shalat jenazah adalah tidak kurang dari 6 orang, jumlah minimal barisan jama'ah shalat jenazah yang disunnahkan untuk dibentuk adalah tiga baris. Sedangkan jumlah maksimalnya adalah tidak dibatasi.

Hal ini sesuai pula dengan konsep pertidaksamaan linear satu variabel $\mathrm{x} \geq 6$, yaitu apabila akan dilaksanakan shalat jenazah, jama'ah dapat membentuk tiga barisan ketika jumlah jama'ah mencapai minimal 6 orang.

\section{Posisi Barisan Shalat Jenazah}

Posisi barisan jama'ah shalat jenazah mengandung konsep garis. Garis merupakan himpunan titik-titik yang berderetan. Pada shalat jenazah, jama'ah shalat berdiri saling berderetan dalam satu baris, hingga deretannya tersebut berhenti pada seseorang yang berdiri di kedua ujung barisan kanan dan kiri sesuai panjang barisan. Jika satu orang dalam barisan tersebut diibaratkan sebagai sebuah titik, maka semua orang dalam barisan terebut diibaratkan sebagai titik-titik yang berderetan hingga menjadi sebuah garis.

Ketika barisan pertama sudah dipenuhi dengan sejumlah orang, maka dibuatlah barisan kedua, ketiga, keempat, dan seterusnya di belakang barisan pertama. Dengan posisi setiap barisan sejajar dan tubuh jama'ah shalat menghadap ke kiblat dan jenazah. Hal ini sesuai dengan konsep garis sejajar, dimana barisan-barisan tersebut berjarak sama dalam satu bidang datar dan tidak pernah berpotongan meskipun diperpanjang sampai tak hingga.

\section{Jumlah Takbir Dalam Shalat Jenazah}

Takbir dilakukan secara berulang sebanyak 4 kali. Hal ini sesuai dengan konsep perkalian yang merupakan penjumlahan berulang. Misalkan perkalian a x b adalah penjumlahan bilangan $b$ sebanyak a kali, jadi

$$
\begin{gathered}
a \times b=b+b+b+\ldots+b \\
\text { Sebanyak a kali }
\end{gathered}
$$

Oleh karena itu, misal a adalah jumlah pengulangan takbir dalam shalat jenazah. Dan $b$ adalah jumlah takbir dalam 1 rakaat. Maka, perkalian bilangan cacah pada takbir shalat jenazah yaitu: $4 \underbrace{\times 1=1+1+1+1}=4$

\section{Posisi Berdiri Imam Terhadap Jenazah Laki-Laki dan Perempuan}

Dalam Al-Jaziri (2019) dijelaskan bahwa saat shalat jenazah, imam shalat berdiri di samping jenazah yang berbaring dengan posisi kepala jenazah di sisi utara dan kakinya di sisi selatan. Jika jenazah laki-laki, maka imam berdiri dengan posisi badan menghadap kiblat sekaligus ke arah sisi kepala jenazah. Dan jika jenazah perempuan, maka imam berdiri dengan posisi badan menghadap kiblat sekaligus ke arah sisi pinggul jenazah.

Pada posisi tersebut, mengandung konsep titik di luar garis. Jika dilihat dari atas, maka kedudukan jenazah yang berbaring dapat diibaratkan sebagai sebuah garis. Dan 
Vol 2 No 2 Desember 2021

Jurnal AlphaEuclidEdu

Received: 08/09/2021; Resived: 13/10/2021; Accepted: 30/12/2021

imam yang berdiri di sampingnya dapat diibaratkan sebagai sebuah titik. Sehingga tempat berdiri imam tidak menjadi bagian dari tempat berbaringnya jenazah, sebagaimana konsep titik di luar garis.

\section{Posisi Berdiri Seseorang Dalam Shalat Jenazah Terhadap Jenazah}

Pada saat berdiri, jika dilihat dari samping, maka posisi berdiri tegak tersebut menyerupai konsep ruas garis. Yaitu garis yang dibatasin oleh dua titik di kedua ujungnya. Termasuk di dalamnya terdapat pula konsep garis vertikal, yaitu garis yang tegak. Garis vertikal di sini adalah garis yang diilustrasikan dengan posisi berdiri seseorang di atas lantai yang melaksanakan shalat jenazah, dan posisinya tegak lurus dengan lantai tempat jenazah dibaringkan yang diilustrasikan sebagai garis horizontalnya. Artinya, jenazah yang berbaring dapat diibaratkan sebagai garis horizontal. Sebagaimana konsep garis tegak lurus, orang yang shalat dan jenazah dapat diibaratkan sebagai dua buah garis yang saling berpotongan tegak lurus.

Selain itu, orang yang berdiri dalam shalat jenazah, posisi tubuhnya membentuk sudut $180^{\circ}$. Dengan pinggang diibaratkan sebagai titik pangkal dari dua buah garis yang dibentuk. Kemudian bagian tubuh dari pinggang ke atas hingga kepala diibaratkan sebagai garis pertama, dan bagian tubuh dari pinggang ke bawah hingga ke kaki diibaratkan sebagai garis kedua. Karena ketika berdiri, posisi kepala dan kaki dianggap lurus dalam satu bidang, maka sudut yang terbentuk antara bagian tubuh atas dengan bagian tubuh atas dengan pinggang sebagai titik pangkalnya adalah $180^{\circ}$.

\section{Memakamkan Jenazah}

\section{Bentuk dan Ukuran Lubang Kubur}

Lubang kubur yang digali bentuknya menyerupai sebuah bangun ruang yaitu balok. Bentuk lubang tersebut memiliki ciri-ciri yang sama dengan balok, yaitu memiliki 6 buah sisi, yang berbentuk persegi panjang. Kemudian 3 pasang sisinya saling sejajar.

Adapun elemen-elemen pada balok yaitu sisi panjang, lebar dan tinggi juga terdapat pada lubang kubur. Sisi panjang pada lubang bersesuaian dengan tinggi badan jenazah, sisi lebar bersesuaian dengan lebar badan jenazah, dan sisi tinggi bersesuaian dengan kedalaman kuburan, yaitu setinggi berdirinya orang dewasa sambil mengangkat tangan ke atas.

\section{Simpulan dan Saran Simpulan}

Berdasarkan hasil penelitian yang dilakukan, dapat ditarik kesimpulan sesuai dengan jawaban dari rumusan masalah yaitu konsep matematika sekolah yang terdapat di dalam pemulasaraan jenazah adalah sebagai berikut: (1) Konsep Persegi panjang kelas I dan II SD; (2) Konsep Operasi hitung bilangan campuran kelas VI SD; (3) Konsep Operasi Penjumlahan kelas I, II, dan III SD; (4) Konsep Operasi pengurangan kelas I dan II SD; (5) Konsep Operasi perkalian kelas II dan V SD; (6) Konsep Operasi pembagian kelas II SD; (7) Konsep Barisan bilangan kelas VIII SMP; (8) Konsep Himpunan kelas VII SMP; (9) Konsep Pertidaksamaan Linear satu variabel kelas VII SMP; (10) Konsep Ruas garis kelas II SD; (11) Konsep Garis vertikal kelas II SD; (12) Konsep Garis horizontal kelas II SD; (13) Konsep Garis sejajar kelas IV SD; (14) Konsep Garis tegak lurus kelas IV SD; (15) Konsep Titik di luar garis kelas VII SMP; (16) Konsep Sudut $180^{\circ}$ kelas III SD; dan (17) Konsep balok kelas I dan II SD. 
Vol 2 No 2 Desember 2021

Jurnal AlphaEuclidEdu

Received: 08/09/2021; Resived: 13/10/2021; Accepted: 30/12/2021

\section{Saran}

Saran-saran yang dapat peneliti berikan setelah melakukan penelitian yaitu: (1) Kepada peneliti lain yang hendak meneruskan penelitian ini, hendaknya dapat memperbanyak buku referensi agar lebih banyak konsep matematika yang dapat digali; (2) Kepada guru yang mengambil manfaat dari penelitian ini, hendaknya dapat menyampaikan pentingnya pemulasaraan jenazah dengan metode dan situasi yang sesuai dengan kondisi kelas. Serta tidak lupa menyampaikan kepada siswa bahwa dalam pemulasaraan jenazah, terdapat konsep matematika seperti yang dipelajarinya di kelas.

\section{Referensi}

Al-Albani, Muhammad Nashiruddin. 2018. Fiqih Jenazah Menurut Al-Qur'an dan As-Sunnah. Jakarta: Pustaka Imam Syafi'i.

Al-Jaziri, Abdurrahman. 2019. Shalat dalam Fiqih 4 Mazhab. Jakarta: Noura Books.

Diah, Eka Kartiningrum. 2015. Panduan Menyusun Studi Literatur. Mojokerto: Lembaga Penelitian dan Pengabdian Masyarakat.

Fadhli Rabbani, Abu. 2017. Ahkamul Jana'iz Panduan Lengkap Mengurus Jenazah. Bogor: Media Tarbiyah.

Faishal bin Abdul Aziz Alu Mubarak. 2014. Riyadush Shalihin \& Penjelasannya. Jakarta: Ummul Qura.

Hobri.; Susanto.; Syaifuddin, Mohammad.; Maylistiyana, Dhika Elvira.; Hosnan.; Cahyanti, Anggraeny Endah.; Syahrinawati, Khoirotul Alfi. 2018. Senang Belajar Matematika Untuk SD/MI Kelas IV. Jakarta: Kemendikbud.

Mustofa, Amin.; Buchori.; Juliatun, Erna.; Hidayah, Isti. 2008. Senang Matematika Untuk SD/MI Kelas 2 Jilid 2. Jakarta: Depdiknas.

Permendikbud Nomor 21 Tahun 2016. Standar Isi Pendidikan Dasar dan Menengah. Jakarta: Lampiran Permendikbud nomor 21 tentang Muatan Matematika.

Pusfitasari, Eka. 2017. Eksplorasi Konsep Matematika Dalam Sistem Hukum Waris Islam Masyarakat Semudun. Skripsi. Untan Pontianak.

Sidiq, Umar.; Choiri, Moh Miftahul. 2019. Metode Penelitian Kualitatif Di Bidang Pendidikan. Ponorogo: CV. Nata Karya.

Soedjadi, R. 2000. Kiat Pendidikan Matematika Di Indonesia. Jakarta: Depdiknas.

Transyah, Eri Agus. 2018. Analisis Contoh Kontekstual Konsep Matematika Sekolah Yang Terdapat Dalam Ibadah Shalat. Skripsi. Untan Pontianak. 
Vol 2 No 2 Desember 2021

Jurnal AlphaEuclidEdu

Received: 08/09/2021; Resived: 13/10/2021; Accepted: 30/12/2021

\title{
ANALISIS GAYA BELAJAR VISUAL DITINJAU DARI KEMAMPUAN PEMECAHAN MASALAH SISTEM PERSAMAAN LINEAR DUA VARIABEL
}

\author{
Aribah Errina, Mohamamad Rif'at, Silvia Sayu \\ Program Studi Pendidiikan Matematika FKIP Untan Pontianak \\ Mahasiswa: errinaaribah@ gmail.com
}

\begin{abstract}
This review means to depict the investigation of visual learning styles as far as critical thinking capacity of understudies' two-variable direct condition framework at MTS Negeri 3 Mempawah. The examination strategy utilized is enlightening subjective as contextual analyses. The subjects in this study were class VIII students at MTS Negeri 3 Mempawah. The number of students who were used as research subjects were 38 students who had studied the material for a two-variable system of linear equations. In this study, six students were selected consisting of two students who had SPLDV Problem Solving Ability in terms of high, medium, low learning styles. The object of this exploration is Visual Learning Style as far as Critical thinking Capacity. In light of the aftereffects of information examination, meetings and conversation, it can be concluded that Analysis of Visual Learning Styles Judging from the SPLDV Problem-Solving Ability of MT.S Negeri 3 Mempawah Students" shows that students' problem-solving abilities are relatively balanced with learning styles. As a rule, understudies who have high numerical critical thinking capacities have great visual learning styles, understudies with moderate critical thinking capacities have great visual learning styles, understudies with low numerical critical thinking capacities have great visual learning styles.
\end{abstract}

Keywords: Critical Thinking, Two Variable Direct Condition System, Visual Learning Style

\section{Pendahuluan}

Menurut Gagne dan Briggs (1988:182) hakikat pembelajaran secara umum adalah serangkaian latihan yang dimaksudkan untuk memberdayakan sistem pembelajaran agar terjadi. Pembelajaran menyarankan setiap tindakan yang dimaksudkan untuk membantu orang memperoleh kemampuan tertentu. Pembelajaran dapat diartikan sebagai suatu siklus yang dicari agar siswa dapat meningkatkan kapasitas terpendamnya, baik intelektual, penuh perasaan maupun psikomotorik dengan sukses dan produktif untuk mencapai perubahan tingkah laku yang normal. Pembelajaran di sekolah memiliki empat hal yang harus dipikirkan, yaitu penataan, pelaksanaan, penilaian dan pengawasan. Latihan pembelajaran tidak hanya berpusat pada upaya untuk memperoleh informasi sebanyak mungkin yang dapat diharapkan secara wajar, tetapi juga bagaimana memanfaatkan semua informasi yang diperoleh untuk mengelola keadaan baru atau menangani masalah luar biasa yang terkait dengan bidang studi yang diteliti. Matematika adalah salah satu ilmu dasar yang memainkan peran penting dalam kehidupan sehari-hari. Oleh karena itu, sejumlah besar energi untuk mengejar soal harus secara konsisten memikirkan peningkatan matematika, penerapan dan penggunaan matematika untuk mengatasi masalah-masalah biasa. Salah satu standar kapasitas numerik adalah menangani masalah numerik.

Kapasitas berpikir kritis numerik adalah bagian penting dari belajar matematika. Namun, sebenarnya kemampuan berpikir kritis numerik siswa sekolah menengah masih 
Vol 2 No 2 Desember 2021

Jurnal AlphaEuclidEdu

Received: 08/09/2021; Resived: 13/10/2021; Accepted: 30/12/2021

sangat rendah. Hal ini dapat dilihat dari konsekuensi ikhtisar PISA dan TIMSS. Konsekuensi dari tinjauan PISA untuk kapasitas numerik secara konsisten, Indonesia secara konsisten mendapat skor di bawah normal dunia dan posisi di bawahnya. Dalam penelitian tersebut, salah satu bagian dari kapasitas intelektual yang dievaluasi adalah kapasitas berpikir kritis numerik. Konsekuensi dari studi PISA 2015, Indonesia berada di posisi 63 dari 70 negara peserta dengan skor normal 386 sedangkan skor normal global 490 (OECD, 2016). Hasil studi TIMMS sangat sedikit tidak sama dengan hasil PISA. Pada tahun 2015 Indonesia menempati posisi ke-45 dari 50 negara dengan skor 397. Artinya, kondisi Indonesia dalam setiap investasinya selalu mendapat skor di bawah batas normal. Mahasiswa yang mengikuti PISA dan delegasi TIMSS dari Indonesia merupakan mahasiswa pilihan terbaik di Indonesia. Dari hasil review, cenderung terlihat bahwa efek samping dari mahasiswa terbaik masih rendah, belum lagi mahasiswa standar lainnya.

Berpikir kritis pada dasarnya adalah suatu usaha untuk menemukan jalan keluar dari suatu kesulitan untuk mencapai suatu tujuan yang tidak dapat dicapai dengan cepat (Polya, 1973); (Teresa et al., 2020). Sesuai dengan itu berpikir kritis adalah interaksi yang dilakukan oleh seorang individu untuk mengurusi masalah yang dihadapinya sampai masalah tersebut pada titik ini bukan masalah bagi individu. Ini berarti bahwa sesuatu adalah masalah bagi seseorang, pada saat yang berbeda itu bukan masalah bagi orang yang bersangkutan. Mengingat persepsi peneliti selama Praktek Pengalaman Lapangan (PPL) dan pertemuan dengan pengajar matematika yang telah dilakukan di MTs Negeri 3 Mempawah tergantung pada hasil yang diperoleh dalam ukuran pembelajaran matematika, masih banyak siswa yang mengalami masalah yang menangani masalah numerik. Hal ini terlihat dari konsekuensi ulangan harian siswa pada materi sebelumnya, khususnya Sistem Persamaan Dua Variabel, yang menunjukkan bahwa dari 64 siswa, 47 siswa atau 73,4\% siswa tidak memenuhi Kriteria Ketuntasan Minimal (KKM). Kriteria nilai tersebut biasanya dimanfaatkan oleh pendidik matematika untuk mengetahui siswa lulus atau tidak nya dalam pencapaian hasil belajar dengan nilai yang ditetapkan 75 .

Menurut Peker (2009: 335); (Halimah et al., 2018), berbagai penelitian telah menunjukkan bahwa secara dominan siswa memiliki kesulitan dalam belajar matematika serta lemah dalam prestasi bidang matematika seperti kemampuan pemecahan masalah yang tentunya membutuhkan penalaran. Seperti yang ditunjukkan oleh Peker (2009:335), penelitian yang berbeda menunjukkan bahwa siswa secara transendental mengalami masalah dalam belajar matematika dan lemah dalam pencapaian dalam aritmatika, misalnya, kemampuan berpikir kritis yang jelas membutuhkan pemikiran. Ada banyak karakteristik siswa yang mempengaruhi hal tersebut seperti usia, jenis kelamin, motivasi, gaya belajar, perkembangan kognitif, perkembangan sosio-emosional, perkembangan moral dan karakter. Namum pada penelitian ini peneliti lebih terfokus pada gaya belajar siswa. Gaya belajar dapat dikelompokkan menjadi tiga yaitu gaya belajar visual, gaya belajar mendengar, dan gaya belajar sensasi. 1) gaya belajar visual menjelaskan bahwa seseorang dengan gaya belajar ini pada awalnya harus melihat bukti dan kemudian memiliki pilihan untuk mempercayainya, misalnya melalui representasi, gambar, rekaman, dan lain-lain; 2) Selain itu, gaya belajar mendengar adalah gaya belajar yang bergantung pada pendengaran untuk memiliki pilihan untuk memahami dan mempercayainya; 3) Gaya belajar sensasional adalah gaya belajar dimana seorang individu menggunakan bagian-bagian tertentu dari tubuhnya sebagai perangkat belajar yang ideal (DePotter dan Hernacki, 2009: 116); (Armiyansyah et al., 2021). 
Vol 2 No 2 Desember 2021

Jurnal AlphaEuclidEdu

Received: 08/09/2021; Resived: 13/10/2021; Accepted: 30/12/2021

Penelitian sebelumnya tentang kapasitas berpikir kritis dan gaya belajar, khususnya akibat dari ujian Dewi Mentari (2019) yang menyimpulkan bahwa subjek diverger, konvergen, akomodator, dan asimilator menunjukkan berbagai kapasitas dalam sistem berpikir, khususnya subjek konvergen dan asimilator keduanya menggunakan contoh yang sama. juga, koneksi untuk mengembangkan tebakan atau tebakan dan spekulasi terkait dengan informasi yang dimiliki, namun subjek asimilator lebih metodis. Berangkat dari landasan yang digambarkan di atas, maka penulis tertarik untuk mengarahkan sebuah kajian yang berjudul "Analisis Gaya Belajar Visual Ditinjau Dari Kemampuan Pemecahan Masalah Sistem Persamaan Linier Dua Variabel Siswa di MTS Negeri 3 Mempawah".

\section{Metode Penelitian}

Eksplorasi semacam ini adalah penelitiank kualitatif. Untuk mencapai tujuan penelitian, peneliti mengumpulkan informasi yang diperoleh, kemudian menyusun eksplorasi yang menghasilkan struktur cerita yang ditunjukkan dengan apa yang terjadi selama pemeriksaan di lapangan (Nawawi, 2015: 67). Oleh karena itu, strategi yang akan digunakan dalam eksplorasi ini adalah metode deskriptif. Jenis eksplorasi yang digunakan dalam tinjauan ini adalah investigasi kontekstual. Subjek dalam review ini adalah siswa kelas VIII di MTS Negeri 3 Mempawah. Jumlah siswa yang dijadikan sebagai subjek ujian adalah 38 siswa yang telah membaca materi sistem persamaan dua variabel.

Dalam tinjauan ini dipilih enam mahasiswa yang terdiri dari dua mahasiswa yang memiliki Kapasitas Berpikir Kritis SPLDV tinggi Dilihat dari Gaya Belajarnya, dua mahasiswa yang memiliki Kapasitas Berpikir Kritis sedang, dan dua mahasiswa yang memiliki Kapasitas Berpikir Kritis rendah. Alasan ilmuwan memilih enam siswa sebagai subjek ujian adalah agar analis dapat menyelam lebih jauh ke dalam Gaya Belajar Visual sejauh kemampuan berpikir Kritis SPLDV siswa.

Objek penelitian ini adalah Pengambilan Visual dalam Gaya Memutuskan Kemampuan Berpikir Kritis siswa SPLDV tinggi, sedang dan rendah. prosedur yang digunakan untuk mengumpulkan informasi adalah strategi korespondensi yang menyimpang, metode pengujian yang disusun, dan strategi korespondensi langsung. Strategi korespondensi backhanded adalah sebagai polling gaya belajar ke atas dari 15 pernyataan yang akan diberikan sebelum siswa mengerjakan soal kemampuan berpikir kritis SPLDV. Strategi tes yang disusun adalah melalui pemberian kemampuan berpikir kritis. Strategi korespondensi langsung adalah metode pengumpulan informasi melalui pertanyaan yang disampaikan secara lisan. Dalam ulasan ini, strategi korespondensi langsung sebagai pertemuan. Instrumen Ujian seperti Poll Gaya Belajar, Soal Tes Kapasitas Berpikir Kritis, dan rapat.

\section{Tahap Persiapan}

Sarana yang ditempuh pada tahap persiapan antara lain: (1) Mengarahkan pra penelitian pada siswa kelas VIII di MTS Negeri 3 Mempawah. (2) Menyusun rencana proposisi pemeriksaan yang mencakup presentasi, audit hipotetis, teknik penelitian, dan rencana instrumen eksplorasi. (3) Mengembangkan instrumen eksplorasi seperti survei gaya belajar siswa, soal tes kemampuan berpikir kritis, dan aturan rapat. (4) Lokakarya 
Vol 2 No 2 Desember 2021

Jurnal AlphaEuclidEdu

Received: 08/09/2021; Resived: 13/10/2021; Accepted: 30/12/2021

rencana eksplorasi. (5) Ubah konfigurasi pemeriksaan tergantung pada efek samping bengkel. (6) Melakukan persetujuan isi pada instrumen pemeriksaan. (7) Memeriksa dan mempertimbangkan kembali instrumen penelitian tergantung pada hasil persetujuan. (8) Mengarahkan uji coba instrumen survei gaya belajar siswa dan inkuiri tes kemampuan berpikir kritis kepada 35 siswa kelas VIII di MTS Negeri 3 Mempawah. (9) Menyelidiki dan memodifikasi instrumen penelitian tergantung pada konsekuensi pendahuluan. (10) Menyebutkan kewenangan memimpin penelitian di MTS Negeri 3 Mempawah.

\section{Tahap Pelaksanaan}

Langkah-langkah yang dilakukan pada tahap pelaksanaan antara lain: (1) Pemberian survey gaya belajar kepada 35 siswa kelas VIII MTS Negeri 3 Mempawah. (2) Merinci konsekuensi dari polling gaya belajar siswa dan mengklasifikasikan survei gaya belajar siswa. (3) Pemberian soal tes kemampuan berpikir kritis SPLDV. (4) Menyelidiki efek samping dari jawaban tes kemampuan berpikir kritis SPLDV siswa. (5) Pertemuan langsung. (6) Mengarahkan pemeriksaan hasil rapat. (7) Menggambarkan informasi eksplorasi. (8) Mencapai kesimpulan untuk menjawab rencana masalah.

\section{Tahap Akhir Penelitian}

Tahap terakhir adalah mengumpulkan laporan pemeriksaan.

\section{Hasil Penelitian dan Pembahasan}

Instrumen yang digunakan dalam pengumpulan informasi adalah polling gaya belajar, tes kemampuan berpikir kritis, dan pertemuan. Jajak pendapat tersebut terdiri dari 15 hal proklamasi yang terdiri dari tiga penanda survei gaya belajar, khususnya visual, pendengaran, dan sensasi. Efek samping dari penyelidikan survei gaya belajar membawa pengumpulan gaya belajar. Tes kapasitas berpikir kritis adalah sebagai penggambaran yang terdiri dari empat pertanyaan dimana setiap pertanyaan mengandung setiap penanda kapasitas berpikir kritis. Dalam aksi pertemuan tersebut, ahli mengungkap lebih banyak tentang kemampuan berpikir kritis yang tidak ditemukan dalam hasil tes yang disusun. Penyelidikan informasi dilakukan secara subjektif di mana analis memperkenalkan informasi sebagai akun, tabel, dan garis besar.

\section{Analisis data angket gaya belajar}

Setelah klasifikasi dilakukan seperti yang ada pada lampiran, siswa dikelompokan dalam msing-masing tipe gaya belajar. Konsekuensi dari koleksi siswa tergantung pada efek samping dari survei gaya belajar dapat ditemukan pada tabel di bawah ini.

Tabel 1. Pengelompokan Siswa Berdasarkan Hasil Angket Gaya Belajar

\begin{tabular}{|c|c|c|c|c|c|c|}
\hline \multirow{2}{*}{ No. } & \multirow{2}{*}{ Kode siswa } & \multicolumn{3}{|c|}{ Skor } & \multirow{2}{*}{ Gaya Belajar } & \multirow{2}{*}{ Keterangan } \\
\cline { 3 - 5 } & V & A & K & & Jawaban dominan visual \\
\hline 1 & KSH & 15 & 12 & 10 & Visual & Jawaban dominan visual \\
\hline 2 & RSA & 16 & 8 & 9 & Visual & Jawaban dominan visual \\
\hline 3 & APN & 15 & 10 & 11 & Visual & Jawaban dominan visual \\
\hline 4 & RMD & 17 & 10 & 11 & Visual & Jawaban dominan visual \\
\hline 5 & WN & 16 & 12 & 10 & Visual & Jawaban dominan visual \\
\hline 6 & AKR & 17 & 9 & 11 & Visual & Jawn visual \\
\hline 7 & RH & 17 & 9 & 8 & Visual & Jawaban dominan venann \\
\hline
\end{tabular}


Vol 2 No 2 Desember 2021

Jurnal AlphaEuclidEdu

Received: 08/09/2021; Resived: 13/10/2021; Accepted: 30/12/2021

\begin{tabular}{|c|c|c|c|c|c|c|}
\hline 8 & QA & 16 & 9 & 8 & Visual & Jawaban dominan visual \\
\hline 9 & NN & 15 & 8 & 11 & Visual & Jawaban dominan visual \\
\hline 10 & EGA & 16 & 9 & 8 & Visual & Jawaban dominan visual \\
\hline
\end{tabular}

Berdasarkan analisis data yang sudah dilakukan pada hasil pengisian kuesioner angket gaya belajar 10 siswa kelas VIII yang menjadi subjek di MTS Negeri 3 Mempawah cenderung gaya belajar visual.

\section{Analisis Data Kemampuan Pemecahan Masalah}

Setelah siswa koleksi keyakinan melalui efek dari jajak pendapat gaya belajar yang diberikan kepada siswa, siswa diberikan tes kemampuan berpikir kritis numerik. Kapasitas berpikir kritis numerik yang terdiri dari empat pertanyaan penggambaran dengan empat petunjuk, khususnya: (1) Memahami Masalah; (2) Membuat Pengaturan Finishing; dan (3) Melaksanakan Pengaturan; (4) Meninjau Balasan. Efek samping dari tes kapasitas berpikir kritis numerik diperkenalkan pada Tabel di bawah ini.

Tabel 2. Hasil Tes Kemampuan Pemecahan Masalah

\begin{tabular}{|c|c|c|c|c|c|c|c|c|}
\hline \multirow{2}{*}{$+\mathrm{No}$} & \multirow{2}{*}{ Inisial Siswa } & \multicolumn{4}{|c|}{ Butir Soal } & \multirow{2}{*}{ Skor Total } & \multirow{2}{*}{ Persentase } & \multirow{2}{*}{ Kriteria } \\
\hline & & 1 & 2 & 3 & 4 & & & \\
\hline 1 & RMD & 4 & 4 & 4 & 3 & 15 & 93,75 & Tinggi \\
\hline 2 & RSA & 4 & 3 & 3 & 3 & 13 & 81,25 & Tinggi \\
\hline 3 & $\mathrm{WN}$ & 3 & 4 & 3 & 3 & 13 & 81,25 & Tinggi \\
\hline 4 & KSH & 3 & 3 & 3 & 2 & 11 & 68,75 & Sedang \\
\hline 5 & $\mathrm{RH}$ & 3 & 3 & 3 & 2 & 11 & 68,75 & Sedang \\
\hline 6 & NN & 3 & 3 & 3 & 2 & 11 & 68,75 & Sedang \\
\hline 7 & APN & 3 & 3 & 2 & 2 & 10 & 62,5 & Sedang \\
\hline 8 & AKR & 3 & 3 & 2 & 2 & 10 & 62,5 & Sedang \\
\hline 9 & QA & 3 & 3 & 2 & 1 & 9 & 56,25 & Rendah \\
\hline 10 & EGA & 2 & 2 & 2 & 2 & 8 & 50 & Rendah \\
\hline
\end{tabular}

Berdasarkan hasil tes kemampuan berpikir kritis numerik siswa yang disajikan pada Tabel 2, pada umumnya setelah skor per angka dijumlahkan, siswa yang memiliki kemampuan berpikir kritis numerik tinggi adalah 3 siswa atau 30\%, siswa yang memiliki kemampuan berpikir kritis numerik sedang adalah 5 siswa atau setengahnya, dan siswa yang memiliki kemampuan berpikir kritis numerik rendah adalah 2 siswa atau $20 \%$.

Analisis Data Tes Kemampuan Pemecahan Masalah Matematis Ditinjau dari Angket Gaya Belajar

Penelusuran akibat tes kemampuan berpikir kritis numerik untuk melihat kemampuan berpikir kritis numerik siswa pada materi sistem persamaan linear dua variabel sejauh gaya belajar disajikan pada tabel.

Tabel 3. Hasil Tes Kemampuan Pemecahan Masalah Matematis dan Gaya Belajar Kelas VIII Mts.N 3 Mempawah

\begin{tabular}{|l|l|l|l|l|l|l|}
\hline No. & & Butir Soal & Skor Total & Persentase & Kriteria \\
\hline
\end{tabular}


Vol 2 No 2 Desember 2021

Jurnal AlphaEuclidEdu

Received: 08/09/2021; Resived: 13/10/2021; Accepted: 30/12/2021

\begin{tabular}{|c|c|c|c|c|c|c|c|c|c|}
\hline & $\begin{array}{c}\text { Kode } \\
\text { siswa }\end{array}$ & $\begin{array}{c}\text { Skor } \\
\text { Visual }\end{array}$ & 1 & 2 & 3 & 4 & & & \\
\hline 1 & RSA & 80 & 4 & 3 & 3 & 3 & 13 & 81,25 & Tinggi \\
\hline 2 & RMD & 85 & 4 & 4 & 4 & 3 & 15 & 93,75 & Tinggi \\
\hline 3 & WN & 80 & 3 & 4 & 3 & 3 & 13 & 81,25 & Tinggi \\
\hline 4 & KSH & 75 & 3 & 3 & 3 & 2 & 11 & 68,75 & sedang \\
\hline 5 & APN & 75 & 3 & 3 & 2 & 2 & 10 & 62,5 & sedang \\
\hline 6 & AKR & 85 & 3 & 3 & 2 & 2 & 10 & 62,5 & sedang \\
\hline 7 & RH & 85 & 3 & 3 & 3 & 2 & 11 & 68,75 & sedang \\
\hline 8 & NN & 75 & 3 & 3 & 3 & 2 & 11 & 68,75 & sedang \\
\hline 9 & QA & 80 & 3 & 3 & 2 & 1 & 9 & 56,25 & Rendah \\
\hline 10 & EGA & 80 & 2 & 2 & 2 & 2 & 8 & 50 & Rendah \\
\hline
\end{tabular}

Berdasarkan Tabel 3 diperoleh informasi atau data bahwa terdapat tiga siswa yang tergolong memiliki gaya belajar visual dengan tiga siswa memiliki kemampuan berpikir kritis numerik tinggi, lima siswa memiliki kemampuan berpikir kritis numerik sedang, dan dua siswa memiliki kemampuan berpikir kritis numerik rendah.

\section{Pembahasan}

Mengingat efek samping dari ujian eksplorasi survei gaya belajar, tes kemampuan berpikir kritis numerik, dan pertemuan, cenderung terlihat bahwa kapasitas gaya belajar setiap siswa bergeser. Selain itu, siswa yang memiliki gaya belajar yang sama juga dapat memiliki kemampuan berpikir kritis yang berbeda. Hal ini sesuai dengan penilaian Bandler dan Processor (dalam DePorter 2002: 85) yang menyatakan bahwa hampir setiap orang pada umumnya akan membuat mereka belajar gaya yang berperan dalam mengambil, menyiapkan, dan berkorespondensi.

Pharsing (2007: 85). Diungkapkan bahwa ketika siswa menggunakan gaya belajar yang sesuai dengan mereka dalam sistem pembelajaran akan sangat mempengaruhi mereka, memberikan solusi yang nyaman, tetapi juga pada akhirnya akan menjadi obat dalam jangka panjang bagi siswa untuk mendominasi di sekolah. Sejalan dengan itu, pengajar perlu mengenali ragam gaya belajar yang digerakkan oleh siswa seperti yang diungkapkan oleh Martinez-pons (2001: 7) dalam penelitian otak mendidik dan belajar bahwa dalam belajar penting bagi seorang guru untuk melakukan periode yang mendasari pembelajaran, khususnya tahap di mana seorang guru mengetahui dan memahami pengaturan dasar yang dimiliki siswa. Aturan dasar yang diingat untuk tahap ini adalah mengetahui bagaimana jenis gaya belajar siswa sehingga sangat baik dapat dipertimbangkan dan berkontribusi bagi instruktur untuk dapat merancang pembelajaran dengan tujuan untuk lebih mengembangkan kemampuan berpikir kritis numerik siswa.

Dalam keadaan hasil belajar ini, siswa lebih percaya pada masalah aplikasi numerik, termasuk belajar melalui materi kerangka kondisi langsung dua variabel. Hal ini juga menegaskan hipotesis pembelajaran signifikan, khususnya matematika yang dipelajari disesuaikan dan dikaitkan dengan informasi yang dimiliki siswa saat ini dan menjadi signifikan jika dikaitkan dengan gaya belajar visual. Setelah merinci informasi tes jajak pendapat dan tes kapasitas berpikir kritis numerik, mereka terus mengarahkan pertemuan. Alasan dan kapasitas pertemuan dalam penelitian adalah untuk memperoleh 
Vol 2 No 2 Desember 2021

Jurnal AlphaEuclidEdu

Received: 08/09/2021; Resived: 13/10/2021; Accepted: 30/12/2021

data secara lugas untuk memperjelas sesuatu yang spesifik atau keadaan dan kondisi. untuk menyelesaikan dan memperoleh informasi yang tepat untuk menggambarkan hasil informasi yang tepat. Selanjutnya pembahasan lebih mendalam tentang kapasitas berpikir kritis numerik sejauh gaya belajar pada materi sistem persamaan linear dua variabel di MTs.N 3 Mempawah.

\section{Kemampuan pemecahan masalah matematis bagi siswa yang memiliki gaya belajar visual tinggi, sedang dan rendah}

Seorang siswa yang menjadi subjek ujian dari kelompok gaya belajar visual pada penanda pemahaman masalah memperoleh data bahwa ada skor yang dapat diterima dengan klasifikasi tinggi. Siswa-siswa ini memperoleh pencapaian kemampuan berpikir kritis numerik sebesar 93,75\% pada kelas tinggi, 68,75\% pada klasifikasi sedang, dan setengahnya pada kelas rendah.

\section{Kesimpulan dan Saran \\ Kesimpulan}

Berdasarkan hasil penelusuran informasi, pertemuan dan percakapan, maka cenderung diduga bahwa "Analisis Gaya Belajar Visual Ditinjau dari Kemampuan Pemecahan Masalah SPLDV Siswa MT.S Negeri 3 Mempawah" menunjukkan bahwa kemampuan berpikir kritis siswa sangat rendah. umumnya diimbangi dengan gaya belajar. Pada umumnya siswa yang memiliki kemampuan berpikir kritis numerik tinggi memiliki gaya belajar visual yang baik, sedangkan siswa dengan kemampuan berpikir kritis sedang memiliki gaya belajar visual yang baik, serta siswa dengan kemampuan berpikir kritis numerik yang rendah memiliki gaya belajar visual yang baik.

\section{Saran}

Gagasan yang perlu diteruskan oleh para ilmuwan tergantung pada konsekuensi dari tinjauan ini yaitu pendidik matematika diandalkan untuk memikirkan akibat dari ulasan ini dan mengisinya sebagai informasi atau referensi dalam pembelajaran aritmatika, khususnya dalam mengembangkan lebih lanjut kemampuan berpikir kritis numerik siswa pada materi kerangka kondisi langsung dua variabel. Hal ini dapat diketahui dalam satu cara seperti memberikan pertanyaan non-rutin kepada siswa atau mempersiapkan siswa untuk pertanyaan konfigurasi (presentasi masalah). Siswa diandalkan untuk bekerja pada wawasan dan pemahaman ide-ide mereka seperti pelatihan pertanyaan non-rutin diidentifikasi dengan pengaturan kondisi langsung dari dua faktor untuk lebih mengembangkan kemampuan berpikir kritis.

\section{Referensi}

DePorter, Bobbi dan Hernacki, Mike. 2009. Quantum Learning: Membiasakan Belajar Nyaman dan Menyenangkan. Bandung: Kaifa Learning.

Gagne dan Briggs. 1979. Pengertian Pembelajaran. Diakses melalui link http://www.scribd.com/doc/50015294/13/B-Pengertian pembelajaranmenurutbeberapa-ahli (diakses pada tanggal 10 januari 2021).

Nawawi, Hadari. (2012). Metode Penelitian Bidang Sosial. Yogyakarta: Gajah Mada University Press.

Peker, M. (2009). "Pre-Service Teachers' Teaching Anxiety about Mathematics and Their Learning Styles". Eurasia Journal of Mathematics, Science, \& Technology Eductaion. 5 (4), 335-345. 
Vol 2 No 2 Desember 2021

Jurnal AlphaEuclidEdu

Received: 08/09/2021; Resived: 13/10/2021; Accepted: 30/12/2021

Polya. G. (1973) How to Solve It: A New Aspect of Mathematical Method (Second ed). New Jersey: Princeton University Press. Tersedia: https://notendur.hi.is/hei2/teaching/Polya HowToSolveIt.pdf (20 Januari 2021).

Prashing, B (2007). The Power Of Learning Stayles. Memacu anak melejitkan prestasi dengan mengenali gaya belajarnya. Terjemahan nina fauziah. The Power Of Diversity New Ways Of Learning and Teaching Through Learning Styles. 1998. Bandung: kaifa.

Siswono,Tatag Yuli Eko. 2008. Model Pembelajaran Matematika Berbasis Pengajuan Masalah dan Pemecahan Masalah untuk Meningkatkan Kemampuan Berpikir Kreatif. Surabaya: Unesa University Press.

Armiyansyah, Sugiatno, \& Bistari. (2021). Hambatan siswa dalam belajar matematika dikaji dari kepercayaan matematis 1 1,2,3. Jurnal AlphaEuclidEdu, 2(1), 40-50.

Halimah, M., Solfarina, \& Langitasari, I. (2018). Visual imagery strategy as effort to acquire comprehension. Jurnal Profesi Keguruan, 5(1), 135-141.

Teresa, H., Zubaidah, Z., \& Nursangaji, A. (2020). Kemampuan Menyelesaikan Soal Pisa Pada Konten Change and Relationship. Jurnal AlphaEuclidEdu, 1(2), 60. https://doi.org/10.26418/ja.v1i2.42879 
Vol 2 No 2 Desember 2021

Jurnal AlphaEuclidEdu

Received: 24/10/2021; Resived: 24/11/2021; Accepted: 31/12/2021

\title{
IMPLEMENTASI MOODLE SEBAGAI MEDIA PEMBELAJARAN JARAK JAUH
}

\author{
Indah Nopita Sari ${ }^{1 *}$, Annisa Prima Exacta ${ }^{2}$ \\ ${ }_{1,2}$ Pendidikan Matematika FKIP Universitas Bangun Nusantara Sukoharjo \\ Email: indahnovitasari567@gmail.com*, annisa.p.exacta@gmail.com
}

\begin{abstract}
This study aims to determine the results of implementing the Moodle application as a distance learning medium for students who cannot do face-to-face learning, due to the COVID-19 pandemic. This type of research is a qualitative descriptive with a frequency distribution, which is concluded based on the data obtained during the study. The sample studied was 21 students. The results of the study found that there were $16.9 \%$ of students answered strongly agree; $45.5 \%$ of students answered agree; $30.7 \%$ of students answered disagree; $6.9 \%$ of students answered strongly disagree. Some students who answered disagreed or strongly disagreed had problems, namely not having a cellphone/laptop, unstable internet network, and expensive data packages. Educators must carefully prepare the material to be delivered and students must look for a stable network location. In conclusion, using Moodle as a distance learning medium is very effective, to support learning activities that cannot be carried out during the COVID-19 pandemic. The availability of infrastructure is very necessary so that learning objectives can be realized.
\end{abstract}

Keyword: Learning in the network, Moodle

\section{Pendahuluan}

Corona virus disease 2019 atau sering dikenal covid-19 sebagai pandemi berskala global mulai ditetapkan pada tanggal 11 Maret 2020 oleh World Health Organization (WHO), sehingga banyak negara yang menetapkan kebijakan social distancing dan physical distancing untuk menghambat penyebaran Covid-19. Penyakit berbahaya ini menelan korban jiwa yang sangat banyak. Covid-19 Tidak hanya berdampak pada total kematian saja, namun juga berdampak lain. Misalnya dampaknya terhadap ekonomi, kehidupan social, pariwista dan berdampak pada sistem Pendidikan(Kristina Sara et al., 2020). Dampak yang paling terasa pada sistem Pendidikan yaitu dari sistem pembelajaran tatap muka (PTM) berubah menjadi sistem pembelajaran jarak jauh (PJJ). Dalam hal ini sistem pendidikan di indonesia perlu inovasi pembelajaran yang dapat meningkatkan keaktifan dan hasil belajar siswa(Saputri et al., 2019). keberadaan media pembelajaran berpengaruh terhadap peningkatan pemahaman matematis siswa(Matematika, 2019). Maka dari itu mendorong berbagai institusi Pendidikan di Indonesia untuk mengembangkan sistem pembelajaran jarak jauh ini(Chyan, 2021).

Pembelajaran jarak jauh (PJJ) merupakan media pembelajaran menggunakan teknologi, baik berbasis device maupun internet. Salah satu pembelajaran jarak jauh (PJJ) yang sering digunakan adalah berbentuk website online yang dapat diakses fleksibel oleh siswa dari manapun dan kapanpun(Wachid Abdulmajid et al., 2017). Pembelajaran ini akan membentuk semangat belajar mandiri karena siswa dituntut untuk dapat menguasai materi sendiri di rumah, dan juga mendorong interaksi antar siswa, apalagi bagi siswa yang biasanya tidak berani mengungkapkan pendapatnya, mereka akan dapat lebih bebas menyampaikan pendapat/pertanyaan melalui tulisan(Hartatik et al., 2021). Platform pembelajaran jarak jauh (PJJ) yang dapat digunakan oleh tenaga pendidik untuk mengembangkan media pembelajaran jarak jauh sangat banyak diantaranya google classroom, zoom meeting, google meet, moodle, dan lain-lain(Fauzi \& Rahmatih, 2021). 
Vol 2 No 2 Desember 2021

Jurnal AlphaEuclidEdu

Received: 24/10/2021; Resived: 24/11/2021; Accepted: 31/12/2021

Moodle merupakan kepanjangan dari Modular Object-Oriented Dynamic Learning Environment, yaitu aplikasi perangkat lunak yang diproduksi untuk melakukan kegiatan pembelajaran yang flesibel berbasis internet dan website(Sinaga et al., n.d.). Adanya pembelajaran jarak jauh berbasis moodle yang standar platform menggunakan internet bisa menjadi solusi permasalahan tersebut karena sifatnya yang memungkinakan saling terhubung dari berbagai aspek baik interaksi pelajar dan akses refrensi dari internet.

Moodle dapat di download secara gratis pada web yang menyediakan(Tiara Dewi, Muhammad Amir Masruhim, 2016). Strategi penggunaan moodle dalam proses pembelajaran dapat membantu tenaga pendidik ketika tidak dapat memberikan pemantapan materi kepada siswa, pemantapan materi ini dapat di unduh pada fasilitas yang telah disediakan pada moodle. fasilitas yang dimiliki diantaranya pengajuan tugas, forum diskusi, arsip unduhan, ulasan, obrolan, kalender online, pesan, dan kuis online(Sari \& Zulmaulida, 2021). Dengan menggunakan moodle seorang tenaga pendidik dan peserta didik dapat melaksanakan pembelajaran jarak jauh, serta dapat dengan mudah diakses menggunakan laptop ataupun handphone. Pembelajaran dengan menggunakan elearning berbasis moodle menjadikan pembelajaran menjadi menyenangkan dan interaktif serta dapat terkontrol dengan baik selama proses pembelajaran(Inggriyani et al., 2019). Moodle sebagai media pembelajaran memegang peranan penting sebagai media belajarmengajar yang efektif dan efisien(Fahmi \& Priwantoro, 2017).

\section{Metode Penelitian}

Penelitian ini merupakan Penelitian Deskriptif Kualitatif. Penelitian ini mendeskripsikan suatu populasi, kondisi atau kejadian secara sistematis dan akurat. Penelitian ini yang dilakukan dengan setting tertentu yang ada di dalam kehidupan riil (alamiah) dengan maksud menginvestigasi dan memahami fenomena: apa yang terjadi, mengapa terjadi, dan bagaimana terjadinya?(Fadli, 2021).

Objek dalam penelitian adalah siswa kelas X TBO di SMK Bina Patria 1 Sukoharjo yang terdiri dari 21 siswa. Tempat penelitian beralamatkan Gamping, Joho, Kec. Sukoharjo, Kabupaten Sukoharjo, Jawa Tengah 57513. Teknik pengumpulan data menggunakan angket. dimana angket disesuikan dengan kebutuhan, berisi kuisoner tertutup. Pembuatan angket menggunakan media google formulir. Penyebaran link angket kepada siswa dilakukan melalui grup WhatsApp. Kuisoner terdiri dari 20 pernyataan. Jenis instrument dalam penelitian ini adalah menggunakan likert scale, yaitu jawaban yang dipilih oleh responden terdiri dari 4 (empat) pilihan tingkatan yaitu : sangat setuju, setuju, tidak setuju, dan sangat tidak setuju. Jawaban responden akan dikonversikan ke dalam bentuk angka 1-4 sebagaimana dapat lihat pada tabel 1 .

Tabel 1. Penilaian Likert Scale

\begin{tabular}{|l|l|l|}
\hline Jawaban & Singkatan & Nilai \\
\hline Sangat Setuju & SS & 4 \\
\hline Setuju & S & 3 \\
\hline Tidak Setuju & TS & 2 \\
\hline Sangat Tidak Setuju & STS & 1 \\
\hline
\end{tabular}

Tujuan penyebaran dari kuisoner adalah untuk menangkap motivasi, minat dan pendapat narasumber terutama pengalaman narasumber peralihan dari dunia nyata ke dunia virtual selama menggunakan aplikasi moodle. motivasi dan minat narasumber akan 
Vol 2 No 2 Desember 2021

Jurnal AlphaEuclidEdu

Received: 24/10/2021; Resived: 24/11/2021; Accepted: 31/12/2021

mendorong untuk melakukan pembelajaran dengan baik(Aurora \& Effendi, 2019). angket dibagi dalam beberapa bagian. pertama untuk menyelidiki informasi latar belakang umum. Kedua, berisikan pertanyaan seputar komunikasi, bahasa dan teknologi. Ketiga, menyelidiki informasi tentang masyarakat dan opini. Keempat, berisikan info sifat realitas kehidupan nyata(Achmad,2018: 136).

Cara menghitung skor total tiap item dan menghitung persentase perolehan skor total per item (Andriani et al., 2021). Rumus yang digunakan sebagai berikut:

$$
\begin{array}{ll|}
\cline { 2 - 2 } & \\
& P N R S=\frac{\sum_{i=1}^{n} N R S}{N R S \text { maksimum }} \times 100 \% \\
P N R S & =\text { Persentase Nilai Respon Siswa } \\
\sum_{i=1}^{n} N R S & =\text { Total Nilai Respon Siswa pada setiap item pernyataan } \\
N R S \text { mak } & =\text { n x skor pilihan terbaik } \\
\mathrm{n} & =\text { Banyak siswa }
\end{array}
$$

Penelitian ini menggunakan menentukan kategori presentase respon siswa sesuai tabel 2 (Andriani et al., 2021).

Tabel.2 Kategori Persentase Respon Siswa

\begin{tabular}{|l|l|}
\hline Presentase Respon Siswa & Kategori \\
\hline $80 \% \leq N R S$ & Sangat Positif \\
\hline $60 \% \leq \mathrm{NRS}<80 \%$ & Positif \\
\hline $40 \% \leq N R S<60 \%$ & Cukup positif \\
\hline $50 \% \leq \mathrm{NRS}<70 \%$ & Kurang Positif \\
\hline $\mathrm{RS}<50 \%$ & Tidak Positif \\
\hline
\end{tabular}

Triangulasi penelitian ini menggunakan triangulasi sumber yaitu mengkonfirmasikan data yang diperoleh dari suatu sumber dengan sumber lainnya dengan cara membandingkannya lalu dianalisis sehingga menghasilkan kesimpulan.

\section{Hasil dan Pembahasan}

Berdasarkan hasil penelitian dari angket respon siswa yang terdapat 21 pernyataan dengan dihitung persentase setiap item akan disajikan melalui melalui tabel dibawah ini.

Tabel.3 Hasil Analisis Angket dari Siswa

\begin{tabular}{|l|l|c|c|c|l|}
\hline \multirow{2}{*}{ No. } & \multicolumn{1}{|c|}{ Indikator } & \multicolumn{3}{|c|}{ Presentase \% } & \\
\cline { 3 - 5 } & & SS & S & TS & STS \\
\hline 1. & $\begin{array}{l}\text { Saya senang menggunakan moodle saat belajar } \\
\text { secara online }\end{array}$ & 42,9 & 28,6 & 28,6 & 0,0 \\
\hline 2. & $\begin{array}{l}\text { Saya mudah mengakses materi pelajaran pada } \\
\text { moodle }\end{array}$ & 9,5 & 61,9 & 28,6 & 0,0 \\
\hline 3. & Saya mudah mengirimkan tugas pada moodle & 14,3 & 57,1 & 28,6 & 0,0 \\
\hline 4. & $\begin{array}{l}\text { Saya mudah memahami materi yang disampaikan } \\
\text { lewat moodle }\end{array}$ & 9,5 & 57,1 & 33,3 & 0,0 \\
\hline 5. & Saya dapat melihat nilai tugas dan quis pada moodle & 14,3 & 42,9 & 38,1 & 4,8 \\
\hline
\end{tabular}


Vol 2 No 2 Desember 2021

Jurnal AlphaEuclidEdu

Received: 24/10/2021; Resived: 24/11/2021; Accepted: 31/12/2021

\begin{tabular}{|l|l|l|l|l|l|}
\hline 6. & Saya dapat belajar dari sumber lain pada moodle & 9,5 & 66,7 & 19,0 & 4,8 \\
\hline 7. & $\begin{array}{l}\text { Saya dapat berinteraksi dengan teman sekelas } \\
\text { melalui diskusi di moodle }\end{array}$ & 14,3 & 38,1 & 33,3 & 14,3 \\
\hline 8. & $\begin{array}{l}\text { Saya dapat berinteraksi dengan guru melalui diskusi } \\
\text { di moodle }\end{array}$ & 4,8 & 47,6 & 38,1 & 9,5 \\
\hline 9. & $\begin{array}{l}\text { Saya selalu mengakses pembelajaran di moodle } \\
\text { dengan mudah }\end{array}$ & 4,8 & 57,1 & 23,8 & 14,3 \\
\hline 10. & $\begin{array}{l}\text { Saya dapat mengakses pembelajaran di moodle } \\
\text { kapan saja }\end{array}$ & 9,5 & 61,9 & 23,8 & 4,8 \\
\hline 11. & $\begin{array}{l}\text { Saya membutuhkan paket data dalam mengakses } \\
\text { pembelajaran di moodle }\end{array}$ & 38,1 & 52,4 & 4,8 & 4,8 \\
\hline 12. & Biaya paket data mahal harganya & 23,8 & 52,4 & 19,0 & 4,8 \\
\hline 13. & Saya kekurangan biaya membeli paket data & 33,3 & 28,5 & 33,3 & 0,0 \\
\hline 14. & Saya belum mempunyai laptop/handphone & 14,3 & 23,8 & 38,1 & 23,8 \\
\hline 15. & Saya tidak bisa mengakses pembelajaran di moodle & 14,3 & 33,3 & 42,9 & 9,5 \\
\hline 16. & Tempat tinggal saya belum ada jaringan internet & 4,8 & 23,8 & 52,4 & 19,0 \\
\hline 17. & Jaringan internet tidak lancar & 14,3 & 47,6 & 28,6 & 9,5 \\
\hline 18. & $\begin{array}{l}\text { Saya harus mencari lokasi yang ada jaringan internet } \\
\text { untuk mengakses pembelajaran di moodle }\end{array}$ & 14,3 & 52,4 & 23,8 & 9,5 \\
\hline 19. & $\begin{array}{l}\text { Mengakses pembelajaran di moodle membuat saya } \\
\text { stress }\end{array}$ & 23,8 & 23,8 & 52,4 & 0,0 \\
\hline 20. & $\begin{array}{l}\text { Mengakses pembelajaran di moodle, memberikan } \\
\text { wawasan tentang metode pembelajaran }\end{array}$ & 23,8 & 47,6 & 23,8 & 4,8 \\
\hline & Rata-rata & 16,9 & 45,5 & 30,7 & 6,9 \\
\hline
\end{tabular}

Berdasarkan tabel di atas menjelaskan bahwa pada pernyataan siswa senang menggunakan moodle saat belajar secara online pada indikator 1, diambil hasil presentase tertinggi $42,9 \%$ siswa menjawab sangat setuju. Pernyataan siswa mudah mengakses materi pelajaran pada moodle pada indikator 2, diambil hasil presentase tertinggi $61,9 \%$ siswa menjawab setuju. Penyataan siswa mudah mengirimkan tugas pada moodle pada indikator 3, diambil hasil presentase tertinggi 57,1\% siswa menjawab setuju. Pernyataan siswa dapat melihat nilai tugas dan quis pada moodle pada indikator 4 , diambil hasil presentase tertinggi 57,1\% siswa menjawab setuju.

Penyataan siswa dapat melihat nilai tugas dan quis pada moodle pada indikator 5 , diambil hasil presentase tertinggi $42,9 \%$ siswa menjawab setuju. Pernyataan siswa dapat belajar dari sumber lain pada moodle pada indikator 6 , diambil hasil presentase tertinggi $66,7 \%$ siswa menjawab setuju. Penyataan siswa dapat berinteraksi dengan teman sekelas melalui diskusi di moodle pada indikator 7, diambil hasil presentase tertinggi 38,1\% siswa menjawab setuju. Penyataan siswa dapat berinteraksi dengan guru melalui diskusi di moodle pada indikator 8 , diambil hasil presentase tertinggi 47,6\% siswa menjawab setuju. Pernyataan siswa selalu mengakses pembelajaran di moodle dengan mudah pada indikator 9, diambil hasil presentase tertinggi 57,1\% siswa menjawab setuju. Penyataan siswa dapat mengakses pembelajaran di moodle kapan saja pada indikator 10, diambil hasil presentase tertinggi 61,9\% siswa menjawab setuju.

Masih berdasarkan tabel diatas menjelaskan bahawa pada indikator 11 siswa membutuhkan paket data dalam mengakses pembelajaran di moodle, mendapakan hasil 
Vol 2 No 2 Desember 2021

Jurnal AlphaEuclidEdu

Received: 24/10/2021; Resived: 24/11/2021; Accepted: 31/12/2021

presentase tertinggi 52,4\% siswa menjawab setuju. Pada indikator 12 siswa membeli biaya paket data mahal harganya, mendapatkan hasil presentase tertinggi 52,4\%. Pada indikator 13 siswa kekurangan biaya membeli paket data, mendapatkan hasil presentase tertinggi 33,3\% sebagian siswa menjawab sangat setuju dan tidak setuju. Pada indikator 14 siswa belum mempunyai laptop/handphone, mendapatkan hasil presentase tertinggi $38,1 \%$ siswa menjawab tidak setuju. Pada indikator 15 siswa tidak bisa mengakses pembelajaran di moodle, mendapatkan hasil presentase tertinggi 42,9\% siswa menjawab tidak setuju. Pada indikator 16 siswa yang tempat tinggalnya belum ada jaringan internet, mendapatkan hasil presentase tertinggi 52,4\% siswa menjawab tidak setuju. Pada indikator 17 siswa yang jaringan internet tidak lancar, mendapatkan hasil tertinggi 47,6\%. Pada Indikator 18 siswa harus mencari lokasi yang ada jaringan internet untuk mengakses pembelajaran di moodle, mendapatkan hasil presentase tertinggi 52,4\% siswa menjawab setuju. Pada indikator 19 siswa stress saat sedang mengakses moodle, mendapatkan hasil presentase tertinggi 52,4\% siswa menjawab tidak setuju. Pada indikator 20 siswa yang mengakses pembelajaran di moodle, memberikan wawasan tentang metode pembelajaran, mendapatkan hasil presentase tertinggi $47,6 \%$ siswa menjawab setuju.

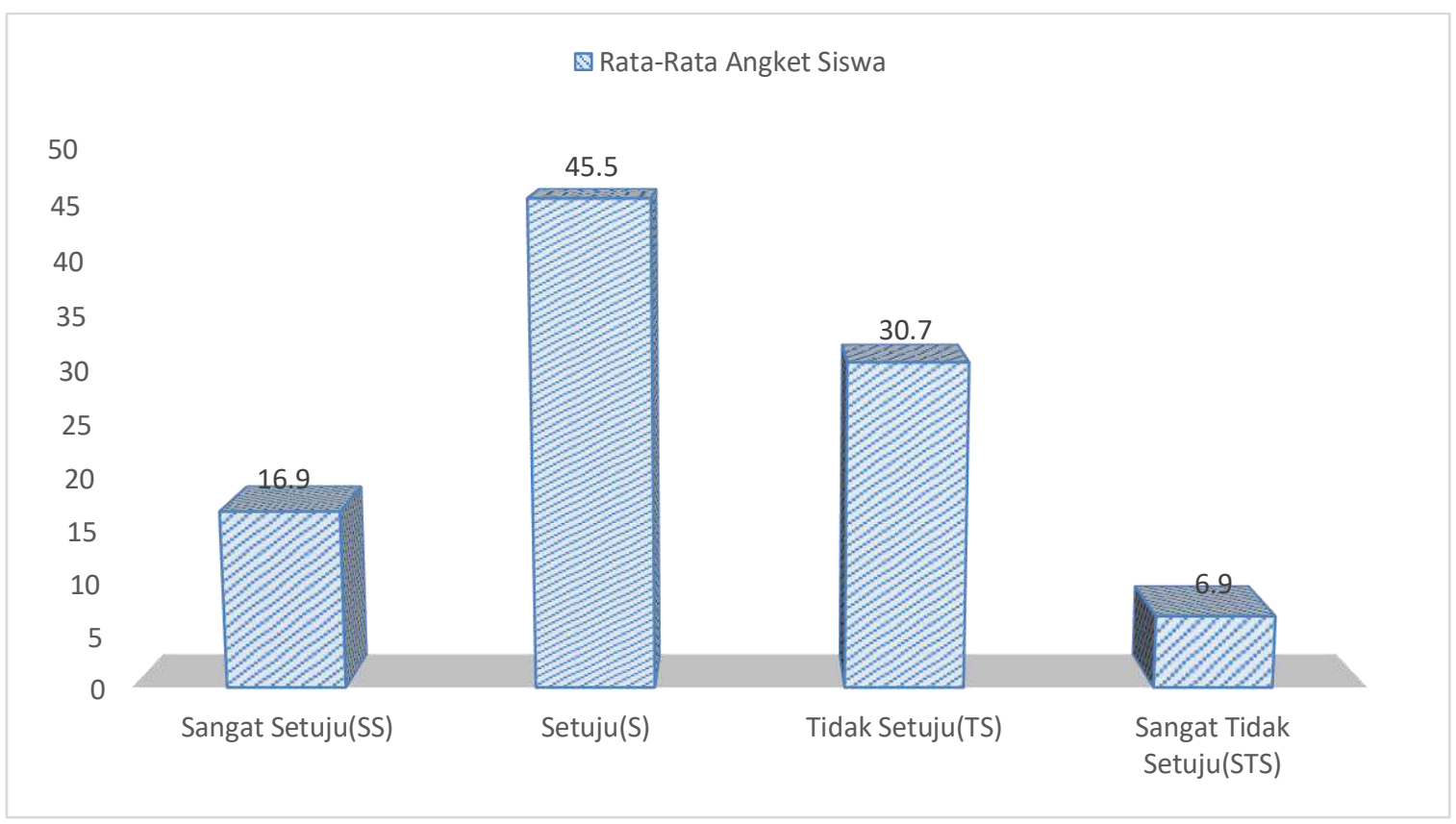

Hasil dari diagram diatas sebagai berikut; $16,9 \%$ siswa yang menjawab sangat setuju; 45,5\% siswa yang menjawab setuju; 30,7\% siswa menjawab tidak setuju; 6,9\% siswa menjawab sangat tidak setuju menggunakan pembelajaran jarak jauh (PJJ) berbasis moodle pada saat pandemi Covid-19. Bagi beberapa siswa yang menjawab tidak setuju dan sangat tidak setuju, itu diakibatkan karena siswa yang bersangkutan belum memiliki laptop/handphone dan jaringan internet yang kurang lancar dikarenakan tempat tinggalnya jauh dari perkotaan.

Berdasarkan hasil penelitian menunjukkan bahwa pembelajaran jarak jauh berbasis moodle merupakan media pembelajaran yang efektif digunakan untuk menangkap motivasi, minat dan pendapat narasumber saat pandemi covid-9. Dimana guru dan siswa masih dapat melakukan pembelajaran, walaupun tidak bertatap muka langsung di kelas 
Vol 2 No 2 Desember 2021

Jurnal AlphaEuclidEdu

Received: 24/10/2021; Resived: 24/11/2021; Accepted: 31/12/2021

dan dilakukan secara jarak jauh. Hal ini dibuktikan dengan hasil 45,5\% siswa menjawab setuju yang berarti termasuk kriteria respon cukup positif melakukan pembelajaran jarak jauh berbasis moodle pada saat pandemi covid-9. Hasil penelitian ini sesuai dengan hasil penelitian lain yang memberikan hasil, pembelajaran jarak jauh berbasis moodle di STMIK Insan Pembangunan dipengaruhi oleh kemudahan penggunaan (perceived ease of use), kegunaan (perceived usefullnes), sikap terhadap penggunaan dan niat untuk menggunakan(Fadhilaturrahmi et al., 2021). Menurut peneliti (Mukahar, 2020) menyimpulkan moodle memjadikan minat belajar peserta didik meningkat, dikarenakan peserta didik menjadi tertarik dan bersemangat dalam mengikuti pembelajaran. Hal ini juga selaras dengan penelitian (Latifah \& Wulandari, 2021) bahwa metode pembelajaran berbasis daring cukup efektif meningkatkan hasil belajar matematika siswa.

Ditemukan juga beberapa kendala yang dialami oleh para siswa, terutama siswa dari orangtua dengan keadaan ekonominya kurang mampu, yang belum mampu untuk membeli leptop maupun handphone serta pulsa data. Para siswa mengeluhkan jaringan internet yang tidak lancar karena daerah mereka belum ada akses jaringan internet yang kuat. Hasil penelitian ini juga sama dengan beberapa hasil peneliti lain yang menyatakan bahwa sebanyak $80 \%$ siswa menyatakan susah mendapatkan sinyal dan boros penggunaan paket data ini disebabkan karena banyak mahasiswa yang tinggal jauh dari daerah perkotaan, dan 50\% siswa yang belum mempunyai laptop/handphone (Astini, 2020). Menurut (Puji et al., 2021) bahwa kendala yang dihadapi peserta didik selama pembelajaran jarak jauh yaitu jaringan internet tidak stabil, pulsa kuota terbatas, sulit fokus, dan aplikasi yang rumit.

Media pembelajaran jarak jauh, memang membutuhkan ketersediaan sarana dan prasarana yang memadai sehingga tujuan pembelajaran dapat tercapai. Moodle juga memberikan kesempatan kepada siswa untuk belajar secara mandiri dan fleksibel dengan mempelajari materi yang sudah disediakan didalam sistem, sehingga siswa dapat belajar kapan saja dan dimana saja. Moodle didesain agar mudah dikembangkan oleh pengguna dengan latar belakang apapun. Penyeleggara Pendidikan dalam penerapan pembelajaran jarak jauh perlu mempersiapakan, antara lain: 1) memberikan pelatihan kepada tenaga pendidik yang akan menggunakannya; 2) menyiapkan Hosting; 3) menyiapkan tenaga teknisi/operator yang memahami hal tersebut. Untuk peserta didik perlu penyiapkan handphone/laptop serta jaringan internet yang stabil. Untuk tenaga pendidik juga harus mau belajar menggunakannya dan bersedia menyiapkan bahan bahan materi yang akan diajarkan. Dengan tersedianya sarana dan prasana, maka tujuan pembelajaran dapat tercapai secara maksimal

\section{Kesimpulan}

Pembelajaran jarak jauh (PJJ) yang selama ini dilakukan menuntut adanya inovasi pembelajaran dalam dunia Pendidikan. Salah satu inovasi yang berkembang pesat saat ini adalah penggunaan pembelajaran jarak jauh berbasis moodle. Berdasarkan hasil penelitian ini disimpulkan bahwa pembelajaran jarak jauh berbasis moodle efektif dijadikan sebagai media pembelajaran jarak jauh pada saat pandemi covid-19. Fitur yang banyak disuguhkan oleh moodle dapat dimanfaatkan oleh siswa untuk belajar secara mandiri dan fleksibel. Ketersediaan sarana dan prasarana sangat diperlukan untuk menunjang kegiatan pembelajaran, maka peserta didik maupun tenaga pendidik harus mempersiapkannya secara matang agar pembelajaran dapat tercapai secara maksimal. 
Vol 2 No 2 Desember 2021

Jurnal AlphaEuclidEdu

Received: 24/10/2021; Resived: 24/11/2021; Accepted: 31/12/2021

\section{Referensi}

Andriani, D., Prasetyo, K. H., \& Astutiningtyas, E. L. (2021). Respon Siswa Terhadap Pembelajaran Dalam Jaringan (Daring) Pada Mata Pelajaran Matematika. Absis: $\begin{array}{llll}\text { Mathematics } \quad \text { Education } & \text { Journal, }\end{array}$ https://doi.org/10.32585/absis.v2i1.830

Aurora, A., \& Effendi, H. (2019). JTEV (JURNAL TEKNIK ELEKTRO DAN VOKASIONAL) Pengaruh Penggunaan Media Pembelajaran E-learning terhadap Motivasi Belajar Mahasiswa di Universitas Negeri Padang. Universitas Negeri Padang. JTEV, 5(2), 11-16. http://ejournal.unp.ac.id/index.php/jtev/index

Chyan, P. (2021). PERANCANGAN LEARNING MANAGEMENT SYSTEM SEBAGAI PENDUKUNG PEMBELAJARAN JARAK JAUH. Rabit : Jurnal Teknologi Dan Sistem Informasi Univrab, 6(1), 7-13. https://doi.org/10.36341/rabit.v6i1.1521

Fadhilaturrahmi, Ananda, R., \& Yolanda, S. (2021). Jurnal basicedu. Jurnal Basicedu, 5(3), 1683-1688.

Fadli, M. R. (2021). Memahami desain metode penelitian kualitatif. Humanika, 21(1), 33-54. https://doi.org/10.21831/hum.v21i1.38075

Fahmi, S., \& Priwantoro, S. W. (2017). Aksiologiya: Jurnal Pengabdian Kepada Masyarakat Pendampingan Pembuatan E-Learning Dengan Moodle Yang Dipadukan Dengan Software Matematika Geogebra Untuk Guru. Jurnal Pengabdian Kepada Masyarakat, 1(2), 135-141.

Fauzi, A., \& Rahmatih, A. N. (2021). E-LEARNING BERBASIS MOODLE SEBAGAI MEDIA PEMBELAJARAN MATEMATIKA DITINJAU DARI. 4(6), 1543-1550. https://doi.org/10.22460/jpmi.v4i6.1543-1550.

Hartatik, T., Hidajat, D., \& Prima, A. (2021). Analisis Keefektifan Google Classroom Dalam Pembelajaran Daring. 3(1), 40-47.

Inggriyani, F., Fazriyah, N., \& Purbasari, A. (2019). Penggunaan E-learning Berbasis Moodle bagi KKG Sekolah Dasar di Kecamatan Lengkong Kota Bandung. Jurnal SOLMA, 8(2), 268. https://doi.org/10.29405/solma.v8i2.3695

Kristina Sara, Ferdianandus Lidang Witi, \& Anastasia Mude. (2020). Implementasi ELearning Berbasis Moodle di Masa Pandemi Covid 19. Journal of Administration and Educational Management (ALIGNMENT), 3(2), 181-189. https://doi.org/10.31539/alignment.v3i2.1813

Latifah, N., \& Wulandari, A. A. (2021). Meningkatkan hasil belajar matematika siswa melalui pembelajaran dengan google meet. 2(2), 46-52.

Matematika, P. P. (2019). IMPLEMENTASI PEMBELAJARAN MENGGUNAKAN MEDIA POCKETBOOK BERBASIS DISCOVERY LEARNING TERHADAP KEMAMPUAN PEMAHAMAN MATEMATIS SISWA Prodi Pendidikan Matematika , IKIP PGRI Pontianak LEARNING IMPLEMENTATION USING POCKETBOOK MEDIA BASED ON DISCOVERY LEARNING ON STUDENTS '. 1 (November).

Mukahar, A. (2020). Pengaruh Media Pembelajaran (Moodle Mobile Learning, LKS) dan Minat Peserta Didik terhadap Hasil Belajar Mata Pelajaran Administrasi Server. Teknologi Dan Kejuruan: Jurnal Teknologi, Kejuruan, Dan Pengajarannya, 
Vol 2 No 2 Desember 2021

Jurnal AlphaEuclidEdu

Received: 24/10/2021; Resived: 24/11/2021; Accepted: 31/12/2021

43(1), 11-19. http://journal2.um.ac.id/index.php/teknologikejuruan/article/view/16637

Puji, T., Indriayudea, J., Estu, T., \& Prima, A. (2021). Analisis Respon Siswa SMK PGRI Sukoharjo Terhadap Pembelajaran Matematika Melalui Media Online. 2(2), 68-76.

Saputri, L. K., Sungkono, J., Studi, P., Matematika, P., Widya, U., \& Klaten, D. (2019). MATEMATIKA MENGGUNAKAN METODE MIND MAP PADA SISWA THE EFFORTS OF ACTIVITY AND STUDENT LEARNING OUTCOME WITH MIND MAP VII GRADE SMP NEGERI 2 TRUCUK. 1(cycle I).

Sari, D. D., \& Zulmaulida, R. (2021). Pengaruh Media Pembelajaran Berbasis MOODLE terhadap Hasil Belajar Matematika Siswa SMP Kelas VIII. 7(2), 75-84.

Sinaga, L., Saragih, L., Sitorus, V. B., \& Panjaitan, L. N. (n.d.). Pemanfaatan Learning Management System dengan Moodle dalam Menunjang Pembelajaran Daring Interaktif. 244-252.

Suni Astini, N. K. (2020). Tantangan Dan Peluang Pemanfaatan Teknologi Informasi Dalam Pembelajaran Online Masa Covid-19. Cetta: Jurnal Ilmu Pendidikan, 3(2), 241-255. https://doi.org/10.37329/cetta.v3i2.452

Tiara Dewi, Muhammad Amir Masruhim, R. S. (2016). 済無No Title No Title No Title. Laboratorium Penelitian Dan Pengembangan FARMAKA TROPIS Fakultas Farmasi Universitas Mualawarman, Samarinda, Kalimantan Timur, 2(April), 5-24.

Wachid Abdulmajid, N., Pramuntadi, A., Ari Budi Riyanto, dan, \& Rochmah, E. (2017). PENERAPAN E-LEARNING SEBAGAI PENDUKUNG ADAPTIVE LEARNING DAN PENINGKATAN KOMPETENSI SISWA SMK DI KABUPATEN BANTUL (Vol. 5, Issue 2). http://jurnal.ustjogja.ac.id/index.php/tamanvokasi 
Vol 2 No 2 Desember 2021

Jurnal AlphaEuclidEdu

Received: 21/09/2021; Resived: 30/10/2021; Accepted: 31/12/2021

\title{
POTENSI PESERTA DIDIK TIPE QUITTER MENYELESAIKAN SOAL OPEN-ENDED MATERI SEGIEMPAT DAN SEGITIGA
}

\author{
${ }^{1}$ Natalia, ${ }^{2}$ Sugiatno, ${ }^{3}$ Silvia Sayu \\ ${ }^{1,2,3}$ Program Studi Pendidikan Matematika FKIP UNTAN \\ Email: natalia00055@gmail.com
}

\begin{abstract}
This study aims to determine the potential description of quitter type students in solving an open-ended question in the material of Quadrilateral and Triangle at SMP Negeri 20 Pontianak. The research method used is a descriptive method with a qualitative approach and a case study research form. The number of subjects in this study was 27 students of class VIII F SMP Negeri 20 Pontianak. The data collection tool used was the Adversity Response Profile $(A R P)$ to get quitter type subjects, open-ended test questions, and interview guides with the help of teaching aids to probe deeper into the potential of quitter-type students. The results of the research on the written test showed that the potential of 2 quitter subjects in solving open-ended questions was still low with a percentage of only $22.22 \%$. However, when interviewed with the help of teaching aids, additional information was obtained that the two quitter subjects showed better potential in solving open-ended questions and were able to provide more than one solution and more than one correct answer.
\end{abstract}

Keywords: Open-Ended question-Solving Potential, Adversity Quotient Quitter Type, Quadrilateral, and Triangle.

\section{Pendahuluan}

Permasalahan mengenai penggembangan potensi peserta didik menjadi perhatian utama dalam program pendidikan. Sekolah sebagai lembaga pendidikan formal bertanggung jawab membantu mempersiapkan peserta didik agar dapat meningkatkan pengetahuan, keterampilan, dan keahlian sesuai dengan potensinya masing-masing. Tuntutan mengenai penggembangan potensi peserta didik dan cara meningkatkannya menjadi tantangan besar bagi guru untuk mewujudkannya.

Terkait dengan tujuan pendidikan untuk mengembangkan potensi peserta didik, Permendikbud No. 22 tahun 2016 yang mengatur tentang Standar Pendidikan Nasional terkait Standar Proses menyatakan bahwa hendaknya proses pendidikan dilaksanakan secara interaktif, inspiratif, menyenangkan, menantang, memotivasi peserta didik untuk berpartisipasi aktif, serta membuat ruang yang cukup bagi perkembangan kreativitas, serta kemandirian sesuai dengan bakat, minat, dan perkembangan fisik serta psikologis peserta didik. Demi tercapainya regulasi tersebut, guru harus menentukan strategi pembelajaran yang dapat memberikan kebebasan berpikir peserta didik secara aktif dan kreatif. Karena segala sesuatu yang peserta didik pelajari hampir seluruhnya bergantung pada pengalaman guru dalam mengajar di dalam kelas setiap harinya, untuk itu hendaknya peserta didik diberikan soal-soal yang dapat menggembangkan potensi mereka secara aktif.

Salah satu solusi yang ditawarkan yaitu dengan memberikan soal-soal Openended yang mempunyai beragam metode dan jawaban penyelesaian sehingga membuat peserta didik secara interaktif menuangkan ide-ide sesuai dengan kesulitan dan kemampuan yang dimiliki (Lestari \& Yudhanegara, 2015). Tujuan diberikannya soal 
Vol 2 No 2 Desember 2021

Jurnal AlphaEuclidEdu

Received: 21/09/2021; Resived: 30/10/2021; Accepted: 31/12/2021

open-ended bukan di lihat dari hasil akhirnya melainkan proses untuk mencapai hasil tersebut, peserta didik dapat mengembangkan metode atau cara penyelesaian yang berbeda saat menyelesaikan soal sehingga dengan beragamnya jawaban yang diberikan dapat terlihat potensi-potensi yang selama ini masih terpendam dalam diri peserta didik.

Namun pada kenyataannya saat menyajikan soal dalam pembelajaran matematika, guru jarang memberikan soal-soal open-ended kepada peserta didik. Hal ini dapat diketahui dari hasil wawancara dengan seorang guru matematika di SMPN 20 Pontianak pada tanggal 8 Agustus 2020 yaitu Ibu Kusnengsih,S.Pd yang menggatakan bahwa beliau belum pernah memberikan soal-soal open-ended melainkan memberikan soal pilihan ganda yang hanya menuntut satu jawaban saja. Soal yang diberikan di sekolah cenderung hanya menekankan pada penghapalan rumus dengan tidak memberikan kebebasan berpikir secara mandiri dan kreatif kepada peserta didik. Akibatnya peserta didik menjadi kurang tertantang dengan soal yang diberikan sehingga mereka tidak aktif menggali potensi yang dimilikinya. Oleh karena itu, potensi peserta didik dalam menyelesaikan soal open-ended perlu dilatih dan dikembangkan agar peserta didik dapat menafsirkan suatu permasalahan dari berbagai sudut pandang yang berbeda dan menghasilkan ide-ide baru dalam menyelesaikan suatu masalah yang jarang diberikan oleh kebanyakan orang.

Satu di antara materi matematika yang dapat diadaptasi menjadi soal open-ended adalah materi bangun datar segiempat dan segitiga. Materi ini termasuk dalam ruang lingkup aspek geometri yang dipelajari di kelas VII SMP. Salah satu kompetensi dasar yang harus dicapai oleh peserta didik pada materi tersebut yaitu peserta didik dapat menyelesaikan soal kontekstual yang berkaitan dengan luas dan keliling segiempat dan segitiga. Demi tercapainya kompetensi yang diharapkan, peserta didik tidak cukup hanya diberikan soal tertutup saja tetetapi diperlukan juga pemberian soal open-ended yang dapat menggembangkan potensi peserta didik secara lebih aktif melalui permasalahan-permasalahan matematika yang menekankan pada pola pikir kreatif guna menyelesaikan soal dengan banyak cara dan banyak jawaban yang benar.

Dalam proses pembelajaran guru harus menyadari bahwa semakin banyak peserta didik maka semakin tinggi pula kemajemukan yang ada di kelas. Hal ini sejalan dengan pendapat Darling-Hammond dkk (Gollub, 2002:59) yang menyatakan dalam pendidikan, guru harus siap menghadapi keragaman substansial dalam pengalaman peserta didik di sekolah seperti bahasa, budaya, kekhasan, gaya belajar, bakat dan kecerdasan. Berdasarkan pengalaman PPL disekolah, peneliti menyadari sekali adanya keragaman yang terjadi di kelas terutama perbedaan kecerdasan peserta didik saat menghadapi kesulitan dalam pembelajaran matematika yang diperkenalkan oleh Stoltz sebagai Adversity Quotient (AQ). Menurut Stoltz Adversity Quotient merupakan salah satu kecerdasan selain IQ dan EQ yang dapat menilai seberapa baik seseorang dapat bertahan atau tidak saat menghadapi kesulitan dan tantangan (Stoltz, 2000). Demikian pula dalam pembelajaran matematika yang penuh dengan tantangan, guru harus mempertimbangkan AQ peserta didik agar pembelajaran matematika dapat menjadi sukses. Kesulitan yang muncul menjadi tantangan tersendiri bagi peserta didik yang tidak mampu menghadapi kesulitan, sehingga dapat memengaruhi tingkat keberhasilannya dalam pembelajaran matematika.

Stoltz (2000: 18) membagi tiga tipe individu di lihat dari tanggapannya menghadapi kesulitan yaitu, quitter (individu dengan AQ rendah), camper (individu 
Vol 2 No 2 Desember 2021

Jurnal AlphaEuclidEdu

Received: 21/09/2021; Resived: 30/10/2021; Accepted: 31/12/2021

dengan AQ sedang), dan climber (individu dengan AQ tinggi). Quitter ditujukan untuk individu yang mudah putus asa dan kurang memiliki dorongan kuat dalam menerima tantangan dalam hidupnya. Camper ditujukan kepada individu yang mudah puas dengan apa yang dicapai dan tidak mau mengorbankan apa yang telah diperolehnya sehingga memilih mundur ketika merasa tidak berdaya lagi. selanjutnya, Climber ditujukan kepada orang yang selalu bersikeras untuk selalu berjuang ketika dihadapkan dengan bermacam kesulitan yang menghambatnya (Wulandari et al., 2020); (Jamiah, 2020).

Melihat fenomena yang sering terjadi di kelas, guru cenderung lebih fokus pada peserta didik tipe climber dan camper serta mengabaikan peserta didik tipe quitter sehingga membuat mereka kurang terakomodir dalam pembelajaran. Hal yang perlu diperhatikan adalah memberikan kesempatan bagi peserta didik tipe quitter untuk membuka kembali peluang keberhasilan dalam pembelajarannya. Peserta didik quitter sangat membutuhkan bantuan guru karena mereka cenderung mudah menyerah, cepat putus asa, pasif, dan tidak bersemangat mencapai puncak penyelesaian suatu masalah. Berdasarkan pada prinsip pembelajaran (NCTM 2000:12) yaitu dalam pembelajaran matematika semua peserta didik terlepas dari karakteristik pribadi, latar belakang, atau tantangan, harus memiliki kesempatan dan dukungan untuk belajar yang setara. Oleh karena itu, sebagai guru wajib memahami perbedaan AQ yang ada didalam peserta didik guna merancang strategi pembelajaran yang sesuai, sehingga potensi yang ada dalam diri peserta didik tipe quitter yang cenderung mudah menyerah, putus asa, pasif, dan tidak bersemangat mencapai puncak dapat dikembangkan dengan maksimal.

Berdasarkan permasalahan di atas, penting bagi guru untuk memberikan soalsoal yang dapat mengembangkan potensi peserta didik dengan tetap memperhatikan adversity quotient karena setiap peserta didik mempunyai potensi dan kemampuan mengatasi kesulitan yang berbeda-beda. Oleh karena itu, dirasa perlu untuk diteliti lebih lanjut terkait potensi menyelesaikan soal open-ended yang ada pada peserta didik tipe quitter. Melalui penelitian ini peneliti tertarik untuk mengambil judul "Potensi Peserta Didik Menyelesaikan Soal Open-Ended Dikaji Dari Adversity Quotient Tipe Quitter Dalam Materi Segiempat dan Segitiga di SMP Negeri 20 Pontianak".

Bersumber pada latar belakang masalah yang telah diuraikan, maka rumusan masalah dari penelitian ini adalah "Bagaimana potensi peserta didik tipe Quitter menyelesaikan soal Open-Ended dalam materi Segiempat dan Segitiga di SMP Negeri 20 Pontianak ?'. Secara umum, tujuan dari riset ini adalah untuk mengetahui gambaran potensi peserta didik tipe quitter menyelesaikan soal open-ended dalam materi segiempat dan segitiga di SMP Negeri 20 Pontianak.

\section{Metode Penelitian}

Berdasarkan tujuan penelitian yang dipaparkan, riset ini menggunakan metode deskriptif dengan pendekatan kualitatif. Bentuk penelitian yang digunakan adalah bentuk penelitian studi kasus. Menurut Susilo Rahardjo dan Gudnanto (2011) studi kasus diartikan sebagai cara yang diterapkan untuk memahami objek secara lebih mendalam dengan dipraktekkan secara integratif serta komprehensif. Menurut Gall dkk. (2003), penelitian korelasional bertujuan untuk menentukan relasi antar variabel dengan pemakaian formula statistik korelasional.

Subjek dalam penelitian ini adalah adalah peserta didik kelas VIII F SMP Negeri 20 Pontianak yang memiliki AQ tipe quitter dan telah mempelajari materi segiempat 
Vol 2 No 2 Desember 2021

Jurnal AlphaEuclidEdu

Received: 21/09/2021; Resived: 30/10/2021; Accepted: 31/12/2021

dan segitiga. Sedangkan objek dalam penelitian ini adalah potensi peserta didik tipe quitter menyelesaikan soal open-ended, khususnya dalam materi segiempat dan segitiga. Teknik pengumpulan data yang digunakan adalah teknik tes dan komunikasi langsung. Teknik tes yang dimaksud dalam penelitian ini berupa tes soal open-ended untuk melihat potensi open-ended peserta didik pada materi segiempat dan segitiga. Tes juga dilakukan untuk menggelompokkan tipe adversity quotient yaitu: climber, camper, dan quitter melalui pemberian ARP (Adversity Response Profile) yang memuat empat dimensi AQ yaitu kendali diri (control), asal- usul dan pengakuan (origin dan ownership), jangkauan (reach), dan daya tahan (endurance). Teknik komunikasi tak langsung berupa wawancara semi terstruktur dengan bantuan alat peraga berupa tangram. Penggunaan alat peraga dalam wawancara ini guna membantu peneliti dalam menggali potensi peserta didik menyelesaikan soal open ended yang tidak dapat terlihat melalui tes tertulis.

Instrumen penelitian yang digunakan untuk melihat potensi peserta didik menyelesaikan soal open-ended diantaranya kisi-kisi soal tes open-ended, soal tes openended, alternatif penyelesaian, dan rubrik penskoran yang telah divalidasi oleh satu orang dosen Pendidikan Matematika FKIP Universitas Tanjungpura dan satu orang guru matematika SMPN 20 Pontianak. Instrumen yang digunakan untuk mengukur adversity quotient berupa kisi-kisi ARP (Adversity Response Profile), dan ARP (Adversity Response Profile) yang telah divalidasi oleh satu orang dosen Bimbingan dan Konseling FKIP Universitas Tanjungpura dan satu orang guru matematika SMPN 20 Pontianak. Karena dalam kondisi pandemi COVID-19 pengumpulan data penelitian dilakukan secara online melalui aplikasi Whatsapp. Setelah terkumpul, data tersebut dianalisis.

Prosedur yang dilakukan dalam penelitian ini terdiri dari tiga tahap sebagai berikut:

\section{Tahap Persiapan}

Langkah-langkah yang dilakukan pada tahap persiapan antara lain: (a) Melakukan observasi awal melalui wawancara dengan guru matematika SMPN 20 Pontianak; (b) Menyusun instrumen penelitian berupa ARP (Adversity Responsse Profile), tes soal open-ended, serta pedoman wawancara; (c) Melakukan validasi instrumen penelitian serta melakukan revisi instrumen penelitian berdasarkan hasil validasi; (d) Melakukan uji coba terhadap instrumen penelitian; (e) Menganalisis dan merevisi data hasil uji coba instrumen.

\section{Tahap Pelaksanaan}

Yang dilakukan pada tahap pelaksanaan yaitu: (a) Memberikan instrumen penelitian berupa tes soal open-ended dan angket ARP (Adversity Response Profile) kepada peserta didik; (b) Menganalisis hasil ARP dan menggolongkan peserta didik sesuai dengan tipe AQ, dalam penelitian ini akan diambil peserta didik dengan tipe quitter; (c) Menganalisis jawaban hasil tes soal open-ended peserta didik tipe quitter; (d) Melakukan wawancara terhadap peserta didik tipe quitter terkait jawaban hasil tes peserta didik.

\section{Tahap Pelaporan}

Langkah-langkah yang dilakukan pada tahap ini yaitu: (a) Membuat kesimpulan dengan cara merangkum data hasil pendeskripsian penelitian; (b) Menyusun laporan setelah semua data yang diperlukan lengkap. 
Vol 2 No 2 Desember 2021

Jurnal AlphaEuclidEdu

Received: 21/09/2021; Resived: 30/10/2021; Accepted: 31/12/2021

\section{Hasil dan Pembahasan}

\section{Hasil Penelitian}

\section{Adversity Quotient Peserta Didik}

Adversity Responsse Profile (ARP) diberikan kepada 27 peserta didik dan berisi 13 pernyataan yang masing-masing pernyataan diikuti oleh dua pertanyaan (26 item) yang memuat 4 indikator untuk mengukur tingkat AQ. Data hasil ARP diolah menggunakan program Ms. Excel 2010. Penskoran ARP bersifat normatif, yang artinya semakin tinggi skor AQ seseorang kemungkinan semakin tinggi pula kemampuannya dalam merespon kesulitan. Berikut jumlah skor dan kategori tingkat AQ subjek penelitian.

Tabel 1. Skor ARP dan Kategori Adversity Quotient Peserta Didik

\begin{tabular}{|c|c|c|c|}
\hline Kategori Adversity Quotient & $\begin{array}{l}\text { Kode Peserta } \\
\text { Didik }\end{array}$ & Jumlah & Persentase \\
\hline Climber & $\begin{array}{c}\text { S1, S2, S4, S5, } \\
\text { S7, S11, S13, S16, } \\
\text { S18, S20, S22, S24, } \\
\text { S25, S26 }\end{array}$ & 14 orang & $51,8 \%$ \\
\hline Camper & $\begin{array}{c}\text { S3, S6, S8, S9, } \\
\text { S10, S12, S15, S17, } \\
\text { S19,S23, S27 }\end{array}$ & 11 orang & $40,7 \%$ \\
\hline Quitter & $\mathrm{S} 14, \mathrm{~S} 21$ & 2 orang & $7,4 \%$ \\
\hline
\end{tabular}

Tabel 1 menunjukkan 14 orang peserta didik memiliki AQ yang tinggi (tipe climber), 11 orang memiliki AQ sedang (tipe camper) dan 2 orang memiliki AQ rendah (tipe quitter). Dalam penelitian ini hanya difokuskan kepada peserta didik dengan tingkat AQ rendah (tipe quitter) maka hanya 2 orang subjek yang akan dianalisis lebih lanjut hasil jawaban tes soal open-ended.

\section{Potensi Peserta Didik Tipe Quitter Menyelesaikan Soal Open-Ended}

Untuk mengetahui potensi peserta didik dalam menyelesaikan soal open-ended diukur menggunakan tes soal open-ended. Tes yang diberikan berupa dua soal uraian materi segiempat dan segitiga yang telah divalidasi dan diuji cobakan. Data hasil tes keterampilan problem solving matematis, diolah menggunakan Ms. Excel 2010. Skor hasil tes soal open-ended peserta didik tipe quitter disajikan di dalam tabel berikut.

Tabel 2. Hasil Tes Potensi dalam Menyelesaikan Soal Open-Ended Peserta Didik Tipe Quitter

\begin{tabular}{|c|c|c|c|c|c|c|c|}
\hline \multirow{2}{*}{ No } & \multirow{2}{*}{ Subjek } & \multicolumn{3}{|c|}{ Skor } & \multirow{2}{*}{ Jumlah } & \multirow{2}{*}{$\%$} & \multirow{2}{*}{ Kategori } \\
\hline & & 1 & $2 a$ & $2 b$ & & & \\
\hline 1 & S14 & 1 & 2 & 0 & 3 & $16,66 \%$ & Kurang \\
\hline 2 & S21 & 2 & 2 & 1 & 5 & $27,77 \%$ & Cukup \\
\hline \multicolumn{2}{|c|}{ Jumlah } & 3 & 4 & 1 & 8 & $44,44 \%$ & \\
\hline \multicolumn{2}{|c|}{ Rata-rata } & \multicolumn{2}{|c|}{3,5} & 0,5 & 4 & $22,22 \%$ & \\
\hline
\end{tabular}


Vol 2 No 2 Desember 2021

Jurnal AlphaEuclidEdu

Received: 21/09/2021; Resived: 30/10/2021; Accepted: 31/12/2021

Tabel 2 menunjukkan bahwa rata-rata persentase skor secara keseluruhan yaitu sebesar 22,22\% dan termasuk dalam kategori kurang. Skor per indikator yang diperoleh yaitu pada aspek terbuka jawabannya dengan rata-rata persentase skor sebesar 3,5\% dan aspek terbuka hasil akhirnya dengan rata-rata skor sebesar $0,5 \%$. Hal ini menunjukkan bahwa potensi peserta didik tipe quitter dalam menyelesaikan soal open-ended masih relatif rendah, ini dapat terlihat dari hasil pekerjaan peserta didik yang hanya menyelesaikan soal dengan 1 jawaban serta 1 cara penyelesaian yang rutin dilakukan.

\section{Hasil Wawancara}

Berdasarkan Tabel 4.1 dan Tabel 4.2 selanjutnya kedua subjek penelitian akan diambil untuk dilakukan wawancara mendalam. Karena pada hasil tes soal open-ended secara tertulis peserta didik tipe quitter belum mampu menunjukkan potensinya dalam menyelesaikan soal, maka pada saat wawancara peneliti menggunakan bantuan alat peraga berupa tangram untuk membantu menggali potensi peserta didik dalam menjawab soal open-ended. Adapun perubahan kemampuan peserta didik tipe quitter dalam menyelesaikan soal open-ended setelah wawancara disajikan di dalam tabel berikut.

Tabel 3. Perubahan Potensi Peserta Didik Tipe Quitter

\begin{tabular}{|c|c|c|}
\hline $\begin{array}{c}\text { Subjek } \\
\text { Penelitian }\end{array}$ & $\begin{array}{c}\text { Jawaban Subjek Sebelum } \\
\text { Wawancara }\end{array}$ & $\begin{array}{c}\text { Jawaban Subjek Saat } \\
\text { Wawancara }\end{array}$ \\
\hline \multirow{3}{*}{ S14 } & $\begin{array}{l}\text { Hanya memberikan satu } \\
\text { jawaban dengan ukuran keramik } \\
1 \mathrm{~cm} \times 1 \mathrm{~cm} \text {, dan tidak bisa } \\
\text { mencari luas dari permukaan } \\
\text { lantai }\end{array}$ & $\begin{array}{l}\text { Mampu memberikan dua } \\
\text { jawaban yang berbeda yaitu } \\
\text { menjawab dengan ukuran } \\
\text { keramik } 1 \mathrm{~cm} \text { x } 1 \mathrm{~cm} \text { dan } 1 \mathrm{~cm} \mathrm{x} \\
2 \mathrm{~cm} \text {, dan mencari luas } \\
\text { permukaan lantai dengan benar }\end{array}$ \\
\hline & $\begin{array}{l}\text { Hanya membuat satu gambar } \\
\text { persegi dari potongan } 3 \text { dan } 5\end{array}$ & $\begin{array}{l}\text { Mampu membuat dua gambar } \\
\text { persegi yang berbeda yaitu } \\
\text { persegi } 1 \text { (potongan } 3 \text { dan 5) dan } \\
\text { persegi } 2 \text { (potongan } 3,5 \text { dan } 7 \text { ) }\end{array}$ \\
\hline & Tidak memberikan jawaban & $\begin{array}{l}\text { Mampu mencari luas persegi } \\
\text { dengan dua cara penyelesaian }\end{array}$ \\
\hline \multirow{3}{*}{ S21 } & $\begin{array}{l}\text { Hanya memberikan satu } \\
\text { jawaban dengan ukuran keramik } \\
1 \mathrm{~cm} \text { x } 2 \mathrm{~cm} \text {, dan menjawab luas } \\
\text { dari permukaan lantai dengan } \\
\text { benar }\end{array}$ & $\begin{array}{l}\text { Mampu memberikan tiga } \\
\text { jawaban yang bervariasi yaitu } \\
\text { menjawab dengan ukuran } \\
\text { keramik } 1 \mathrm{~cm} \times 2 \mathrm{~cm}, 1 \mathrm{~cm} \times 1 \mathrm{~cm} \text {, } \\
\text { dan } 1 \mathrm{~cm} \times 4 \mathrm{~cm}\end{array}$ \\
\hline & $\begin{array}{l}\text { Hanya membuat satu gambar } \\
\text { persegi dari potongan } 3,5 \text { dan } 7\end{array}$ & $\begin{array}{l}\text { Mampu membuat tiga gambar } \\
\text { persegi yang berbeda yaitu } \\
\text { persegi } 1 \text { (potongan } 3,5 \text { dan } 7 \text { ) } \\
\text { persegi } 2 \text { (potongan } 3 \text { dan } 5 \text { ) } \\
\text { persegi } 3 \text { (potongan } 1 \text { dan 2) }\end{array}$ \\
\hline & $\begin{array}{l}\text { Memberikan satu cara } \\
\text { penyelesaian tetapi keliru }\end{array}$ & $\begin{array}{l}\text { Mampu mencari luas persegi } \\
\text { dengan dua cara penyelesaian }\end{array}$ \\
\hline
\end{tabular}


Vol 2 No 2 Desember 2021

Jurnal AlphaEuclidEdu

Received: 21/09/2021; Resived: 30/10/2021; Accepted: 31/12/2021

Berdasarkan Tabel 3, dari hasil wawancara yang sudah dilakukan ditemukan bahwa kedua peserta didik tipe quitter ini menunjukkan potensi menyelesaikan soal open-ended yang baik setelah dibantu dengan alat peraga. Dalam menyelesaikan soal open-ended, kedua peserta didik quitter ini mengerti dengan maksud soal tersebut namun ketika saat mengerjakannya mereka menemukan kesulitan atau berbeda dari soal rutin yang biasa mereka temui mereka memilih berhenti dan tidak mengerjakan soal tersebut.

\section{Pembahasan}

Berdasarkan Tabel 1, adversity quotient peserta didik dikelompokkan dalam 3 tingkatan, yaitu climber, camper, dan quitter. Karena dalam penelitian ini hanya diambil peserta didik tipe quitter, secara umum dari 27 orang peserta didik terdapat 2 orang yang termasuk dalam tipe quitter dengan persentase sebesar 7,4\% dan masing-masing skor ARP nya 42 dan 53. Dari hasil analisis skor ARP, subjek S14 memperoleh skor ARP sebesar 42 dengan masing-masing skor dimensi Control 16, Origin-Ownership 10, Reach 8, dan Endurance 8. Sedangkan subjek S21 memperoleh skor ARP sebesar 53 dengan masing-masing skor dimensi Control 17, Origin-Ownership 11, Reach 12, dan Endurance 6. Grafik perbandingan skor CO2RE masing-masing subjek sebagai berikut.

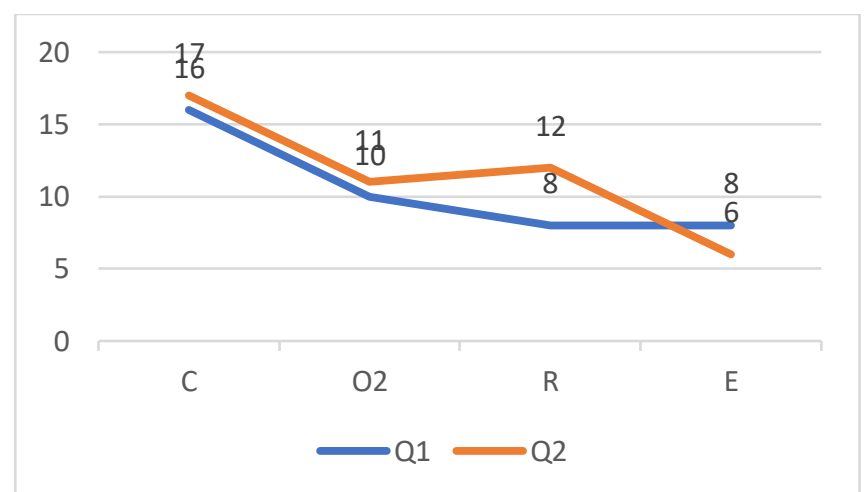

Gambar 1. Grafik Perbandingan Skor CO2RE Subjek S14 dan S21

Berdasarkan analisis data hasil tes, diperoleh bahwa potensi peserta didik tipe quitter dalam menyelesaikan soal open-ended masih rendah. Hal tersebut dapat di lihat dari Tabel 2 yang menunjukkan rata-rata persentase hasil tes potensi kedua peserta didik tipe quitter dalam menyelesaikan soal open-ended secara keseluruhan hanya sebesar $22,22 \%$. Jika di lihat lebih spesifik, skor per indikator potensi peserta didik saat menyelesaikan soal open-ended pada aspek terbuka jawabannya dan aspek terbuka prosesnya termasuk dalam kategori rendah.

Pada soal nomor 1 dan 2a dengan indikator soal yang terbuka jawabannya (mempunyai banyak jawaban yang benar), subjek S14 memperoleh skor 1 dan 2 sementara subjek S21 memperoleh skor 2 dan 2. Berdasarkan rubrik penskoran tes soal open-ended peserta didik memperoleh skor 1 jika memberikan 1 jawaban namun kurang jelas dan belum selesai, dan memperoleh skor 2 jika dapat memberikan 1 jawaban dengan benar, jelas dan lengkap. Hal ini mengindikasikan bahwa subjek S14 dan S21 hanya mampu menyelesaikan soal open-ended dengan 1 jawaban saja. Hal serupa juga ditemukan oleh Sudarman (2011) dalam penelitiannya, ia mengungkapkan bahwa 
Vol 2 No 2 Desember 2021

Jurnal AlphaEuclidEdu

Received: 21/09/2021; Resived: 30/10/2021; Accepted: 31/12/2021

peserta didik tipe quitter saat menggerjakan tugas menunjukkan sikap yang tidak bersemangat, usaha yang minim, dan bekerja seadanya.

Pada soal nomor $2 \mathrm{~b}$ dengan indikator soal yang terbuka prosesnya (mempunyai banyak cara penyelesaian yang benar), subjek S14 memperoleh skor 0 dan subjek S21 memperoleh skor 1. Berdasarkan rubrik penskoran peserta didik memperoleh skor 0 jika tidak memberikan jawaban dan skor 1 jika menjawab dengan menggunakan 1 cara penyelesaian, tetetapi tidak selesai dan keliru. Dari skor ini tampak bahwa subjek S14 sama sekali tidak menuliskan cara mencari luas persegi yang dibuatnya, ini dikarenakan subjek tidak memahami dengan baik maksud dari soal tersebut dan saat mengerjakan soal ini dia mendapati kesulitan ia memilih untuk berhenti dan tidak mengerjakannya sama sekali. Hal ini sesuai dengan teori Stoltz (2000:18) yang menyatakan bahwa individu dengan tipe quitter cenderung memilih untuk menghindari kewajiban, mundur dan berhenti saat menjumpai kesulitan.

Menyadari setiap manusia lahir membawa potensinya masing-masing, sama halnya dengan peserta didik tipe quitter juga mempunyai potensi yang dapat digali dan dikembangkan melalui proses pembelajaran. Jika di lihat dari jawaban hasil tes, peserta didik tipe quitter belum menunjukkan potensinya dalam menyelesaikan soal openended. Sesuai dengan pernyataan Stoltz (2000:34) yang meyakini bahwa quitter tidak selalu ditakdirkan untuk kehilangan kesempatan namun dengan berbagai bantuan dan dorongan, quitter akan mendapat kekuatan untuk bertahan dalam menghadapi kesulitan yang sedang ia hadapi. Untuk itu, pada saat wawancara peneliti berusaha untuk menggali potensi peserta didik tipe quitter lebih dalam dengan variasi bantuan alat peraga berupa tangram.

Berdasarkan hasil wawancara, ditemukan fakta bahwa subjek S14 dan S21 menunjukkan potensi menyelesaikan soal open-ended yang lebih baik ketika diwawancara dengan bantuan alat peraga dibandingkan dengan hasil tes tertulis.

\section{Kesimpulan dan Saran Kesimpulan}

Berdasarkan analsisis hasil tes, diperoleh kesimpulan bahwa potensi peserta didik tipe quitter menyelesaikan soal open-ended dalam materi segiempat dan segitiga pada tes tertulis masih rendah dengan persentase hanya sebesar $22,22 \%$. Hal ini tampak pada hasil tes tertulis yang menunjukkan bahwa peserta didik tipe quitter hanya mampu menyelesaikan soal dengan satu cara penyelesaian dan satu jawaban saja. Namun ketika diwawancara lebih dalam dan dibantu dengan alat peraga diperoleh informasi tambahan bahwa peserta didik quitter menunjukkan potensi yang lebih baik yakni mampu menjawab lebih dari satu cara penyelesaian dan lebih dari satu jawaban dengan benar.

\section{Saran}

Adapun saran-saran yang dapat peneliti berikan adalah sebagai berikut: (1) Bagi peserta didik, diharapkan dapat meningkatkan kemampuan adversity quotient agar tidak mudah menyerah saat menjumpai kesulitan dalam pembelajaran matematika sehingga potensi-potensi yang dimiliki dapat dimanfaatkan dengan baik. (2) Bagi guru, hendaknya dalam mengajar lebih memperhatikan perbedaan adversity quotient yang ada pada peserta didik agar dapat merancang pembelajaran sesuai dengan kebutuhan dan kesulitan peserta didik sehingga potensi perseta didik dapat tergali dengan maksimal. (3) Bagi peneliti selanjutnya, diharapkan dapat melakukan penelitian dengan 
Vol 2 No 2 Desember 2021

Jurnal AlphaEuclidEdu

Received: 21/09/2021; Resived: 30/10/2021; Accepted: 31/12/2021

menggunakan strategi dan tindakan khusus lainnya sehingga dapat menggali potensi peserta didik tipe quitter lebih maksimal.

\section{Referensi}

Gollub, J. P. (2002). Learning and Understanding: Improving Advanced Study of Mathematics and Science in U.S High Schools. Washington, DC: National Academy Press.

Jamiah, Y. (2020). Penguatan Karakter Siswa Perbatasan Melalui Internalisasi Kearifan Lokal Dalam Pembelajaran Matematika. Jurnal AlphaEuclidEdu, 1(2), 69. https://doi.org/10.26418/ja.v1i2.43306

Wulandari, A. C., Sugiatno, S., \& Bistari, B. (2020). Tantangan Belajar Matematika Dalam Materi Aritmatika Sosial Pada Peserta Didik Berkebutuhan Khusus. Jurnal AlphaEuclidEdu, 1(2), 135. https://doi.org/10.26418/ja.v1i2.42898

Lestari dan Yudhanegara. 2015. Penelitian Pendidikan Matematika. Bandung : PT. Refika Aditama.

National Council of Teachers of Mathematics. (2000). Principles and standards for school mathematics. Reston, VA: NCTM.National Council of Teachers of Mathematics (2005). The Open-Ended Approach: A New Proposal for Teaching Mahematics. Reston, VA: NCTM.

Prihadhi, Endra K. (2004). My Potensi. Jakarta: Elek Media Komputindo.

Stoltz, Paul G. (2000). Adversity Quotient: Mengubah hambatan menjadi peluang. Alih bahasa T. Hermaya. Jakarta: PT Gramedia Widiasarana Indonesia (Grasindo).

Sudarman. (2011). Proses Berpikir Siswa Quitter Pada Sekolah Menengah Pertama Dalam Menyelesaikan Masalah Matematika. Jurnal Edumatica 1(2)

Susilo Rahardjo \& Gudnanto. (2011). Pemahaman Individu Teknik Non Tes. Kudus: Nora Media Enterprise.

Gall, Meredith D., Joyce P. Gall, and Borg, W. (2003). Educational research : an Introduction. Boston : pearson education Inc. 
Vol 2 No 2 Desember 2021

Jurnal AlphaEuclidEdu

Received: 21/12/2020; Resived: 24/08/2021; Accepted: 31/12/2021

\title{
IDENTIFIKASI MISKONSEPSI DALAM MENYELESAIKAN SOAL PERTIDAKSAMAAN LINEAR SATU VARIABEL YANG MEMUAT NILAI MUTLAK
}

\author{
Yulya Kusumawati ${ }^{1}$, Halini $^{2}$, Hamdani ${ }^{3}$ \\ ${ }^{1,2,3}$ Program Studi Pendidikan Matematika, FKIP, Universitas Tanjungpura, Pontianak \\ Email: yulya.kusumawati16@gmail.com
}

\begin{abstract}
This research aims to describe the forms of student misconceptions and the factors that cause misconceptions experienced by students in solving linear inequality problems with one variable containing absolute values in class X SMA Muhammadiyah 1 Pontianak. The subjects of this research were students of class X IPA 3 SMA Muhammadiyah 1 Pontianak, totaling 25 students. The research uses descriptive method as the research method. Case study is a form of research used. The results of the research revealed that the research subjects experienced five forms of misconception, namely notation misconceptions experienced by 1 student or by 4\%, generalizing misconceptions experienced by 3 students or by $12 \%$, misconceptions of the application of rules experienced by 6 students or by 24\%, calculation misconceptions experienced by 2 students or by $8 \%$, and specialization misconceptions experienced by 3 students or $12 \%$. The misconceptions experienced by these students are caused by wrong intuition and incomplete reasoning, where students' intuitive thoughts that arise spontaneously when solving problems are still wrong and students' reasoning or logic is still wrong in drawing conclusions and being too broad in generalizing.
\end{abstract}

Keywords: Misconceptions, Two-Tier Diagnostic Test, One Variable Linear Inequality

\section{Pendahuluan}

Pembelajaran matematika yaitu suatu cara siswa dan juga sumber belajar yang saling berinteraksi untuk mempermudah siswa dalam mempelajari matematika. Pembelajaran matematika sendiri memilikitujuan supaya siswa memiliki kompetensi dalam bidang matematika (Firdaus, 2017). Disisi lain, tujuan dari pembelajaran matematika yaitu supaya siswa dapat mengerti konsep matematika, dapat memanfaatkan cara bernalar yang dimilikinya dalam menyampaikan ide dan pernyataan dari matematika, merepresentasikan suatu ide matematika menggunakan simbol atau yang lainnya untuk menjelaskan suatu permasalahan matematika, dan mampu memecahkan masalah matematika (Depdiknas, 2006).

Pembelajaran matematika terdiri dari konsep-konsep yang berurutan, sehingga dapat diartikan bahwa konsep sederhana pada matematika dipakai untuk memahami konsep yang lebih kompleks pada matematika (Ramadhan dkk, 2017: 145). Pernyataan Ramadhan dkk dapat diartikan bahwa konsep-konsep dalam matematika sangat berkaitan. Jika konsep matematika sebelumnya kurang dikuasai maka kemungkinan akan sulit untuk menguasai konsep berikutnya. Sunardi (dalam Isyam dkk, 2019: 75) menyatakan konsep sebagai ide atau gagasan yang bersifat maya dan dipakai untuk mengklasifikasikan beberapa objek apakah objek tersebut merupakan contoh atau bukan contoh. Konsep matematika harus dipahami dengan benar dan tepat karena konsep tersebut akan dipakaiuntuk menyelesaikan masalah yang akan datang. Tayubi (2005: 5) mengemukakan bahwa dalam memahami suatu 
Vol 2 No 2 Desember 2021

Jurnal AlphaEuclidEdu

Received: 21/12/2020; Resived: 24/08/2021; Accepted: 31/12/2021

konsep oleh siswa (konsepsi) bisa saja mengalami kesalahan sehingga konsepsi siswa berbeda dengan konsep yang telah disepakati olehpara ahli atau dengan kata lain siswa dapat dikatakan mengalami miskonsepsi.

Miskonsepsi didefinisikan oleh Suparno(2013: 8) sebagai konsepsi oleh siswa yang tidak selaras dengan konsep yang disepakati ahli-ahli. Miskonsepsi tersebut dapat meneyebabkan siswa sering mengalami kesulitan saat proses pembelajaran. Beberapahal ini dapat menyebabkan siswa mengalami miskonsepsi yakni pengetahuan awal yang dimiliki oleh siswa, pengajar, buku bacaan, dan lingkungannya. Pada tabel berikut ini disajikan penjelasan dari masing-masing penyebab miskonsepsi.

Tabel 1. Penyebab Miskonsepsi Siswa

\begin{tabular}{|c|c|c|}
\hline & Sebab Utama & Sebab Khusus \\
\hline \multirow[t]{8}{*}{1.} & \multirow[t]{8}{*}{ Siswa } & Prakonsepsi \\
\hline & & Pemikiran asosiatif \\
\hline & & Pemikiran humanistik \\
\hline & & Reasoning yang tidak lengkap \\
\hline & & Intuisi yang salah \\
\hline & & Tahap perkembangan kognitif siswa \\
\hline & & Kemampuan atau bakat siswa \\
\hline & & Minat belajar siswa \\
\hline \multirow[t]{4}{*}{2.} & \multirow[t]{4}{*}{ Guru atau Pengajar } & Bukan lulusan dari bidang ilmu matematika \\
\hline & & $\begin{array}{l}\text { Tidak membiarkan siswa mengungkapkan gagasan } \\
\text { atau idenya }\end{array}$ \\
\hline & & Tidak kompeten, tidak menguasai bahan \\
\hline & & Hubungan antara guru dan siswa tidak baik \\
\hline & \multirow[t]{6}{*}{ Buku Teks } & Penjelasan kelinu \\
\hline & & Salah tulis, terutama dalam penulisan rumus \\
\hline & & Tingkat penulisan buku terlalu tinggi bagi siswa \\
\hline & & Siswa tidak tahu membaca buku teks \\
\hline & & $\begin{array}{l}\text { Buku fiksi sains kadang-kadang konsepnya } \\
\text { menyimpang demi menarik pembaca }\end{array}$ \\
\hline & & Kartun sering memuat miskonsepsi \\
\hline & \multirow[t]{7}{*}{ Konteks } & Pengalaman diri siswa \\
\hline & & Bahasa sehari-hari yang berbeda \\
\hline & & Teman diskusi yang salah \\
\hline & & Keyakinan dan agama \\
\hline & & Penjelasan orang tua/orang lain yang keliru \\
\hline & & Konteks hidup siswa (TV, radio,film yang keliru) \\
\hline & & Perasaan senang/tidak senang; bebas/tertekan \\
\hline & \multirow[t]{9}{*}{ Cara Mengajar } & Hanya berisi ceramah dan menulis \\
\hline & & Langsung ke dalam bentuk matematika \\
\hline & & Tidak mengungkapkan miskonsepsi siswa \\
\hline & & Tidak mengoreksi PR yang salah \\
\hline & & Model analogi \\
\hline & & Model praktikum \\
\hline & & Model diskusi \\
\hline & & Model demonstrasi yang sempit \\
\hline & & Non-multiple intelligences \\
\hline
\end{tabular}

Tabel 1 menunjukkan sebab utama dan sebab khusus miskonsepsi siswa. Berdasarkan tabel 1 di atas, penyebab miskonsepsi yang diungkap dalam penelitianini hanya salah satunya saja yaitu penyebab miskonsepsi yang berasal dari siswa terkait prakonsepsi, pemikiran asosiatif, pemikiran humanistik, reasoning yang tidak lengkap, dan intuisi yang 
Vol 2 No 2 Desember 2021

Jurnal AlphaEuclidEdu

Received: 21/12/2020; Resived: 24/08/2021; Accepted: 31/12/2021

salah.

Menurut Leading English Education and Resource Network (LEARN) (dalam Ramadhani, 2014: 17) dan Ashlock (dalam Purwanti, 2019: 9), miskonsepsi yang berasal dari siswa dipisahkan menjadi berbagai bentuk seperti pada tabel berikut.

Tabel 2. Bentuk Miskonsepsi

\begin{tabular}{|c|c|c|}
\hline No. & Bentuk Miskonsepsi & Keterangan \\
\hline 1 & miskonsepsi pengertian huruf & $\begin{array}{l}\text { berupa mengabaikan keberadaan huruf, } \\
\text { tidak dapat membedakan antara huruf yang } \\
\text { digunakan sebagai satuan dan sebagai } \\
\text { variabel, berpikir bahwa huruf sebagai suatu } \\
\text { objek, mempercayai ada aturan yang } \\
\text { digunakan untuk menggunakan angka dari } \\
\text { suatu huruf, berfikir bahwa suatu huruf } \\
\text { memiliki nilai tertentu, berpikir bahwa huruf } \\
\text { yang berbeda mewakili angka yang berbeda, } \\
\text { dan berpikir bahwa suatu huruf merupakan } \\
\text { perwakilan dari suatu bilangan asli }\end{array}$ \\
\hline & miskonsepsi notasi & $\begin{array}{l}\text { berupa kesalahan penggabungan huruf dan } \\
\text { angka disebabkan siswa berfikir simbol } \\
\text { operasi bukan merupakan bagian dari } \\
\text { jawaban dan juga dapat berupa mengabaikan } \\
\text { penggunaan tanda kurung ketika dibutuhkan }\end{array}$ \\
\hline 3 & miskonsepsi penggeneralisasian & $\begin{array}{l}\text { berupa tidak memahami pernyataan penting } \\
\text { dari sebuah metode, ketidakmampuan } \\
\text { menggeneralisasi karena kurang memahami } \\
\text { operasi aritmatika, dan tidak mampu } \\
\text { menggeneralisasi karena siswa tidak mampu } \\
\text { untuk menentukan metode yang } \\
\text { digunakannya }\end{array}$ \\
\hline 4 & miskonsepsi pengaplikasian aturan & $\begin{array}{l}\text { berupa mengabaikan tanda ketika } \\
\text { memanipulasi }\end{array}$ \\
\hline 5 & miskonsepsi perhitungan & $\begin{array}{l}\text { berupa kesalahan dalam perhitungan yang } \\
\text { didasarkan atas pembentukan pola yang } \\
\text { salah dalam perhitungan }\end{array}$ \\
\hline 6 & miskonsepsi penspesialisasian & $\begin{array}{l}\text { berupa menggunakan konsep yang sama } \\
\text { pada permasalahan yang berbeda }\end{array}$ \\
\hline
\end{tabular}

Tabel 2 menjelaskan ada enam bentuk miskonsepsi yang berkemungkinan terjadi pada siswa. Matematika memuat berbagai materi, salah satunya yaitu materi pertidaksamaan dan persamaan linear satu variabel yang memuat nilai mutlak. Adapun kemampuan dasar yang harus dicapai pada materi ini yaitu menjelaskan pertidaksamaan dan persamaan nilai mutlak linear satu variabel dan juga persamaan danpertidaksamaan linear aljabar yang lain, serta menemukan solusi dari persoalan terkait pertidaksamaan dan persamaan nilai mutlak linear satu variabel (Sinaga, 2017: 18).

Menurut informasi dari salah satu guru kelas X SMA Muhammadiyah 1 Pontianak, masih banyak siswa kelas $\mathrm{X}$ yang keliru dalammenyelesaikan soal matematika khususnya di materi pertidaksamaan dan persamaan linear satu variabel yang memuat nilai mutlak. Untuk memperkuat informasi tersebut, peneliti memberikan soal tes terkait materi tersebut kepada 10 siswa kelas X SMA Muhammadiyah 1 Pontianak. Jawaban 10 siswa itu menunjukkan masih banyak siswa yang keliru dalam menemukan solusi soal itu seperti jawaban siswa A terhadap soal yang diberikan oleh peneliti berikut.

6. Tinggi siswa di kelas $\mathrm{X}$ dikatakan sedang apabila tingginya mencapai $160 \mathrm{~cm}$, akan tetapi tinggi siswa ditoleransi boleh beda paling besar $5 \mathrm{~cm}$ dari tinggi yang dikatakan sedang. Tentukan model matematika dari permasalahan tersebut. 
Vol 2 No 2 Desember 2021

Jurnal AlphaEuclidEdu

Received: 21/12/2020; Resived: 24/08/2021; Accepted: 31/12/2021

\section{Gambar 1. Soal Tes Nomor 6}

Gambar 1 di atas menunjukkan soalnomor 6 yang diberikan oleh peneliti ke peserta didik. Di bawah ini jawaban darisiswa A.

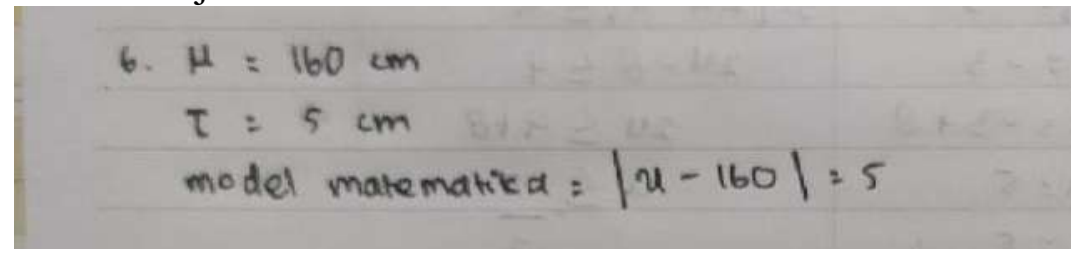

Gambar 2. Jawaban Tertulis Siswa A Terhadap Soal Nomor 6

Gambar 2 menunjukkan bahwa siswa salah dalam menentukan model matematika yang sesuai dengan permasalahan. Tanda penghubung yang seharusnya dipakai adalah tanda penghubung kurang dari sama dengan $(\leq)$. berikut.

Kesalahan lain dilakukan dengan siswa B terhadap soal yang diberikan oleh peneliti

\section{Tentukan nilai $x$ yang memenuhi pertidaksamaan nilai mutlak $|2 x-8| \leq 4$. Gambar 3. Soal Tes Nomor 3}

Gambar 3 di atas menunjukkan soal nomor 3 yang diberikan oleh peneliti ke peserta didik. Di bawah ini jawaban yang diberikan oleh siswa B.

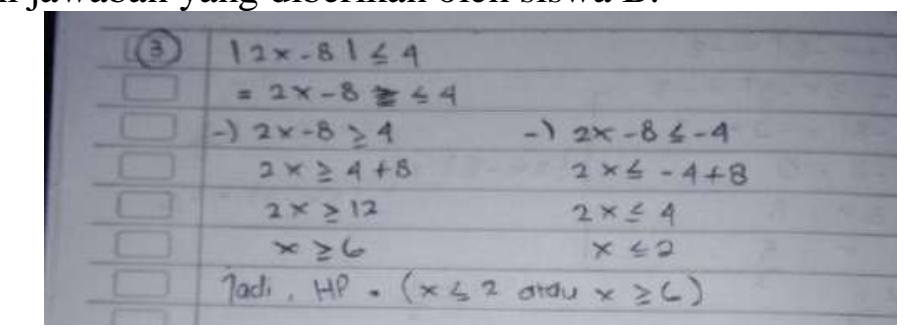

Gambar 4. Jawaban Tertulis Siswa B Terhadap Soal Nomor 3

Gambar 4 memperlihatkan siswa salah keliru mengaplikasikan aturan untuk menyelesaikan permasalahan tersebut. Aturanyang seharusnya digunakan yaitu bagi setiap $a, x$ bilangan real, jika $|x| \leq a$ maka $-a \leq x \leq a$. Dari jawaban siswa A dan siswa B dapat dilihat bahwa masih terdapat kekeliruan. Salah satu kesalahan yang dibuat yakni salah dalam menentukan model matematika. Fakta tersebut selaras dengan sebuah penelitian relevan yang dilaksanakan oleh Ibrahim (2020) dimana menunjukkan kekeliruan siswa berikut.

Dari fakta tersebut, menunjukkan bahwa ternyata masih ada kompetensi dasar yang belum tercapai yaitu menemukan solusi terkait persoalan pertidaksamaan dan persamaan nilai mutlak linear satu variabel. Apabila kekeliruan seperti pada fakta di atas itu terus menerus terjadi maka siswa dapat diduga mengalami miskonsepsi. Miskonsepsi yang terjadi dapat dideteksi melalui two-tier diagnostic test yang merupakan tes diagnostik dengan dua tingkatan. 
Vol 2 No 2 Desember 2021

Jurnal AlphaEuclidEdu

Received: 21/12/2020; Resived: 24/08/2021; Accepted: 31/12/2021

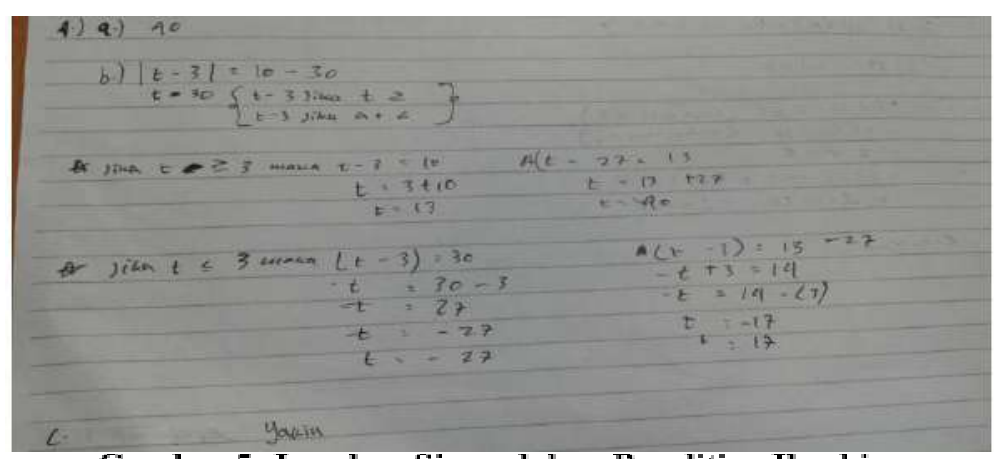

Gambar 5. Jawaban Siswa dalam Penelitian Ibrahim

Menurut penjelasan di atas, peneliti tertarik untuk menggali lebih dalam mengenai miskonsepsi peserta didik dalam menyelesaikan soal pertidaksamaan linear satu variabel yang memuat nilai mutlak. Dengan demikian, dalam penelitian ini dideskripsikan: (1) bentuk-bentuk miskonsepsi yang terjadi pada peserta didik dalam memecahkan persoalan pertidaksamaan linear satu variable yang memuat nilai mutlak di kelas X SMA Muhammadiyah 1 Pontianak, serta (2) mendeskripsikan factor penyebabmiskonsepsi peserta didik.

\section{Metode Penelitian}

Penelitian ini menggunakan metode deskriptif. Bentuk penelitiannya studi kasus. Subjek penelitian ini ialah siswa kelas X IPA 3 SMA Muhammadiyah 1 Pontianak sebanyak 25 siswa. Teknik yang digunakna untuk mengumpulkan data dalam penelitian ini ialah teknik tes beserta non tes. Sementara itu, alat yang digunakan sebagai pengumpul data di penelitian ini two-tier diagnostic test. Jumlah soal yang diberikan kepada siswa yaitu 8 butir yang sudah divalidasi oleh dosen dan guru matematika kelas X SMA Muhammadiyah 1 Pontianak. Jawaban siswa terhadap soal tersebut dapat diklasifikasikan ke dalam 3 kategori dengan ketentuan berdasarkan kombinasi dari jawaban two-tier diagnostic test seperti pada tabel berikut.

Tabel 3. Kombinasi Jawaban Two-Tier Diagnostic Test

\begin{tabular}{lc}
\hline \multicolumn{1}{c}{ Pola jawaban Siswa } & Kategori tingkat Pemahaman \\
\hline Jawaban inti tes benar-alasan benar & Memahami (M) \\
\hline Jawaban inti tes benar-alasan salah & Miskonsepsi (Mi) \\
\hline Jawaban inti tes salah-alasan benar & Tidak Memahami (TP) \\
\hline
\end{tabular}

Tabel 3 menunjukkan apabila kombinasi jawaban siswa berpola benar-benar maka siswa dapat diklasifikasikan ke dalamkategori memahami atau paham konsep (M), apabila kombinasi jawaban siswa berpola benar-salah dan salah benar maka siswa diklasifikasikan ke dalam kategori miskonsepsi (Mi), dan apabila kombinasi jawaban siswa berpola salahsalah makasiswa diklasifikasikan ke dalam kategori tidakpaham konsep (TP).

Selain dengan tes diagnostik, peneliti juga menggunakan pedoman wawancara sebagai alat pengumpulan data. Peneliti menggunakan pedoman wawancara non terstruktur untuk menggali informasi dari siswa. Langkah-langkah penelitian ini ialah sebagai berikut.

\section{Tahap Persiapan}

Tahap ini melipuiti: (1) menjalankan pra-survey di SMA Muhammadiyah 1 Pontianak, (2) merangkai alat-alat penelitian, (3) menjalankan validasi alat-alat penelitian, (4) memperbaiki alat-alat penelitian sesuai dengan hasil validasi, (5) mengadakan uji coba alat-alat penelitian, (6) menelaah data hasil uji coba alat-alat penelitian, (7) memperbaiki alat-alat penelitian sesuai sesuai dengan hasil uji coba, dan (8) menetapkan waktu penyelenggaraan penelitian. 
Vol 2 No 2 Desember 2021

Jurnal AlphaEuclidEdu

Received: 21/12/2020; Resived: 24/08/2021; Accepted: 31/12/2021

Tahap Pelaksanaan

Tahap ini melpiuti: (1) memberikan tes diagnostik kepada subjek penelitian; (2) menyortir siswa yang memahami (M), miskonsepsi (Mi), serta yang tidak memahami (TP); seta (3) melakukan wawancara kepada siswa yang terdeteksi miskonsepsi untuk mngetahui bentuk beserta penyebabnya.

\section{Tahap Akhir}

Tahap ini melpiuti: (1) menganalisis hasil jawaban soal tes beserta wawancara, (2) hasil penelitian dideskripsiakn, serta (3) menarik simpulan.

\section{Hasil dan Pembahsan}

\section{Hasil Penelitian}

Soal two-tier diagnostic test yang berjumlah 8 butir soal diberikan kepada 25 peserta didik dengan tujuan untuk mengetahui banyak siswa yang mengalami miskonsepsi di setiap butir soalnya. Berdasarkan jawaban siswa terhadap two-tier diagnostic test diperoleh hasil seperti pada tabel ini.

\begin{tabular}{ccccc}
\multicolumn{5}{c}{$\begin{array}{c}\text { Tabel 4. Rekapitulasi Jumlah Siswa Berdasarkan Two-Tier } \\
\text { Diagnostic Test pada Tiap Butir Soal }\end{array}$} \\
\hline $\begin{array}{c}\text { Butir } \\
\text { Soal }\end{array}$ & $\begin{array}{c}\text { Kategori Siswa } \\
\text { Konsep }\end{array}$ & Miskonsepsi & $\begin{array}{c}\text { Paham } \\
\text { Konsep }\end{array}$ & $\begin{array}{c}\text { Tidak } \\
\text { Menjawab }\end{array}$ \\
\cline { 2 - 5 } & 0 & 0 & 24 & 1 \\
\hline 1 & 1 & 1 & 22 & 1 \\
\hline 2 & 1 & 7 & 15 & 2 \\
\hline 3 & 1 & 2 & 21 & 1 \\
\hline 4 & 0 & 2 & 22 & 1 \\
\hline 5 & 8 & 2 & 14 & 1 \\
\hline 6 & 1 & 3 & 20 & 1 \\
\hline 7 & 15 & 0 & 9 & \\
\hline 8 & & & & 1 \\
\hline
\end{tabular}

Tabel 4 memperlihatkan banyak siswa pada masing-masing kategori pemahaman konsep. Berikut ini disajikan tabel rekapitulasi siswa yang miskonsepsi pada butir soal nomor 2, 3, 4, 5, 6, dan 7 .

\begin{tabular}{l}
\multicolumn{6}{l}{ Tabel 5. Rekapitulasi Siswa yang Mengalami Miskonsepsi pada Tiap Butir Soal } \\
\begin{tabular}{ccccc}
\hline Butir Soal & Jumlah & Kode Siswa & $\%$ \\
\hline 2 & 1 & FAG & $4 \%$ \\
\hline 3 & 7 & AFY, BA, FV, MZ, NHB, PA, WA & $28 \%$ \\
\hline 4 & 2 & FAG, RAS & $8 \%$ \\
\hline 5 & 2 & FAG, WA & $8 \%$ \\
\hline 6 & 2 & FT, NB & $8 \%$ \\
\hline 7 & 3 & AAP, DE, MFAV & $12 \%$ \\
\hline Jumlah & 17 & & \\
\hline
\end{tabular}
\end{tabular}

Menurut tabel 5 peserta didik paling banyak miskonsepsi di butir soal nomor 3 yakni 7 siswa atau sebanyak 28\%. Berdasarkan jawaban peserta didik terhadap soal two-tier diagnostic test serta hasil wawancara antara peneliti dengan peserta didik yang mengalami miskonsepsi diperoleh beberapa bentuk miskonsepsi dan penyebab miskonsepsi yang disajikan di tabelberikut. 
Vol 2 No 2 Desember 2021

Jurnal AlphaEuclidEdu

Received: 21/12/2020; Resived: 24/08/2021; Accepted: 31/12/2021

Tabel 6. Rekapitulasi Bentuk dan Penyebab Miskonsepsi Siswa

\begin{tabular}{lcccc}
\hline \multicolumn{1}{c}{ Bentuk Miskonsepsi } & Kode Siswa & Jumlah & $\%$ & $\begin{array}{c}\text { Penyebab } \\
\text { Miskonsepsi }\end{array}$ \\
\hline $\begin{array}{l}\text { Miskonsepsi Pengertian } \\
\text { Huruf }\end{array}$ & - & 0 & $0 \%$ & - \\
\hline Miskonsepsi Notasi & AAP & 1 & $4 \%$ & $\begin{array}{c}\text { Intuisi yang } \\
\text { Salah }\end{array}$ \\
\hline $\begin{array}{l}\text { Miskonsepsi } \\
\text { Penggeneralisasian }\end{array}$ & DE, FAG, MFAV & 3 & $12 \%$ & $\begin{array}{c}\text { Reasoning } \\
\text { yang Tidak } \\
\text { Lengkap dan } \\
\text { Intuisi yang } \\
\text { Salah }\end{array}$ \\
\hline $\begin{array}{l}\text { Miskonsepsi } \\
\text { Pengaplikasian Aturan }\end{array}$ & AFY, BA, FV, MZ, & 6 & $24 \%$ & $\begin{array}{c}\text { Reasoning } \\
\text { yang Tidak } \\
\text { Lengkap }\end{array}$ \\
\hline Miskonsepsi Perhitungan & FAG, WA & 2 & $8 \%$ & $\begin{array}{c}\text { Reasoning } \\
\text { yang Tidak } \\
\text { Lengkap }\end{array}$ \\
\hline $\begin{array}{l}\text { Miskonsepsi } \\
\text { Penspesialisasian }\end{array}$ & FT, NB, RAS & 3 & $12 \%$ & $\begin{array}{c}\text { Reasoning } \\
\text { yang Tidak } \\
\text { Lengkap }\end{array}$ \\
\hline
\end{tabular}

Tabel 6 menunjukkan bahwa peserta didik paling banyak mengalami miskonsepsi pengaplikasian aturan. Terdapat 6 siswa atau sebanyak 24\% siswa mengalami miskonsepsi pengaplikasian aturan dan kebanyakan miskonsepsi siswa disebabkan oleh rasoning yang tidak lengkap.

\section{Pembahasan}

Menurut data di tabel 6, diperolehinformasi bahwa ada lima bentuk miskonsepsiyang terjadi pada peserta didik kelas X IPA 3 SMA Muhammadiyah 1 Pontianak yakni miskonsepsi notasi, penggeneralisasian, pengaplikasian aturan, perhitungan dan penspesialisasian dengan penyebab intuisi yang salah dan reasoning yang tidak lengkap. Intuisi yang salah timbul secara spontan pada saat siswa sedang menyelesaikan soal. Hal ini selaras dengan pendapat Suparno (2013: 29) yang menyatakan bahwa miskonsepsi dapat disebabkan oleh pemikiran intuisi siswa yang sering membuat siswa tidak kritis terhadap pemikirannya tersebut. Intuisi yang dialami siswa muncul secara spontan dalam bentuk gagasan yang belum pernah dianalisis sebelumnya. Sedangkan reasoning yang tidak lengkap dapat dikarenakan siswa belum sepenuhnya memahami materi yang dijelaskan. Pernyataan itu sejalan dengan Comins (dalam Suparno, 2013: 38) menjelaskan bahwa miskonsepsi dapat disebabkan oleh reasoning yang salah atau tidak lengkap yang terjadi karena penalaran atau logika peserta didik salah dalam membuat keseimpulan atau generalisasi. Selain itu, pengamatan siswa yang tidak lengkap dan tidak akurat juga dapat menyebabkan kesimpulan yang salah dan mengakibatkan miskonsepsi.

Tabel 5 memperlihatkan bahwa AAP terdeteksi miskonsepsi pada soal butir 7 serta bentuk miskonsepsinya ialah notasi yang tertera di tabel 6 . Tabel 6 juga memperlihatkan bahwa penyebab miskonsepsinya ialah intuisi yang salah. AAP menyelesaikan soal nomor 7 dengan menggabungkan angka dan huruf yang beradadi dalam kurung mutlak sehingga $\mid x-$ $80 \mid<20$ menjadi $|-80 x|<20$ dan AAP memilih alasan pada opsi C yaitu jawaban diperoleh dengan menggabungkan suku-suku yang tidak sejenis. Seharusnya $|x-80|<20$ menjadi $-20<x-80<20, x-80$ tidak bisa digabung menjadi $-80 x$. Hasil jawaban AAP menunjukkan bahwa AAP menyamakan angka dan huruf yang posisinya sebagai nilai mutlak tersebut. Kemudian FAG merubah $|2 x+4|-|3 x+6| \geq 0$ menjadi $2 x+4 \geq 0$ dan $3 x$ $+6 \geq 0$, lalu menentukan nilai $x$ dari masing-masing pertidaksamaan yaitu untuk $2 x+4 \geq 0$ kedua ruasnya dikurang 4 dapatlah $2 x \geq-4$ kemudian kedua ruasnya dikali dengan 1 dapatlah $x \geq$ variabel di dalam kurung mutlak tersebut serta AAP mengerjakan soal tersebut 
Vol 2 No 2 Desember 2021

Jurnal AlphaEuclidEdu

Received: 21/12/2020; Resived: 24/08/2021; Accepted: 31/12/2021

sesuai dengan -2 dan untuk $3 x+6 \geq 0$ kedua ruas gagasannya sendiri yang muncul secara spontan ketika mneyelesaikan soal.

Terlihat dari tabel 6 ada sebanyak 3 siswa yaitu DE, FAG, dan MFAV yang mengalami miskonsepsi penggeneralisasian. DE menyelesaikan soal nomor 7 tidak menggunakan konsep nilai mutlak tetapi dengan menggunakan rumus jarak dimana 20 sebagai jarak dan 80 sebagai kecepatan, kemudian DE menghitung jarak dibagi dengan kecepatan sehingga diperoleh hasil $20 / 80=1 / 4$. DE memperoleh gagasan tersebut dari pikiran atau penalarannya sendiri yang kurang lengkap. Reasoning atau penalaran DE yang kurang lengkap ini menyebabkan DE mengalami miskonsepsi. Dari jawaban DE, dapat terlihat bahwa DE kurang memahami konsep nilai mutlak.

Gagasan DE dalam menyelesaiakan soal nomor 7 mirip dengan cara yang MFAV lakukan yakni tidak menggunakan konsep nilai mutlak tetapi langsung dengan operasi pembagian yaitu $20 \mathrm{~km} / 80 \mathrm{~km}$ sehingga diperoleh 1/4. Cara tersebut muncul dalam benak MFAV secara spontan ketika MFAV menyelesaikan soal. Hal ini berarti cara tersebut diperoleh dari intuisi MFAV yang salah sehingga mengakibatkan MFAV tidak dapat mengambil kesimpulan atau menggeneralisasi dengan tepat metode apa yang dapat digunakan untuk menyelesaikan soal nomor 7. Jawaban MFAV menunjukkan MFAV belum memahami dengan tepat konsep nilai mutlak.

Lain halnya dengan FAG, FAG terdeteksi mengalami miskonsepsi penggeneralisasian di soal butir 5. FAG menyelesaikan soal butir 5 dengan menggunakan aturan yang tak sesuai yaitu $|2 x+4| \geq|3 x+6|$ menjadi $|2 x+4|-|3 x+6| \geq 0$ tanpa mengkuadratkan kedua dikurang dengan 6 diperoleh $3 x \geq-6$ kemudian kedua ruas dikali dengan diperoleh $x \geq-2$. Seharusnya pada $|2 x+4| \geq|3 x+6|$ kedua ruas dikuadratkan terlebih dahulu agar kurung mutlaknya tidak ada baru kemudian dilanjutkan dnegan operasi-operasi pertidaksamaan untuk memperoleh nilai $x$. Cara tersebut FAG peroleh dari intuisinya sendiri. Intuisi FAG yang masih salah ini mengakibatkan FAG tidak dapat mengambil kesimpulan atau menggeneralisasi dengan benar metode yang seharusnya diterapkan untuk menyelesaikan soal nomor 5 sehingga dapat diperoleh kesimpulan bahwa FAG kurang paham tentang konsep nilai mutlak.

Siswa dengan kode AFY, BA, FV, MZ, NHB, dan PA terdeteksi mengalami miskonsepsi pengaplikasian aturan pada soal nomor 3. AFY, BA, FV, MZ, NHB, dan PA menyelesaikan soal nomor 3 dengan cara yang benar, tetapi terdapat kesalahan yaitu $-20 x>$ 20 menjadi $x>-1$, seharusnya $-20 x>20$ menjadi $x<-1$. AFY, BA, FV, MZ, NHB, dan PA yakin bahwa pengerjaannya sudah benar. Hal ini disebabkan karena informasi yang diperoleh saat pembelajaran kurang detail dan berlanjut terjadi ketika siswa menyelesaikan soal dimana reasoning siswa atau penalarannya tidak lengkap sehingga menyebabkan miskonsepsi. Dari jawabannya, keenam siswa tersbeut masih kurang memamhami sifat pertidaksamaan linear dimana ketika kedua ruas dikali atau dibagi dengan bilangan negatif maka tanda pertidaksamaan akan berubah.

Dalam tabel 6 juga diperoleh informasi mengenai siswa yang mengalami miskonsepsi perhitungan sebanyak 2 siswa yaitu FAG dan WA. FAG terdeteksi mengalami miskonsepsi perhitungan pada soal butir 2 serta 4 . FAG menyelesaikan soal butir 2 serta 4 dengan cara yang benar, tetapi terdapat kesalahan menghitung seperti pada nomor 2 yaitu $x^{2}+8 x+16-$ $x^{2}+12 x-36<0$ menjadi $x^{2}+20 x-20<0$ dan pada nomor 4 yaitu $x^{2}+2 x+1-x^{2} \leq 0$ menjadi $x^{2}+2 x+1 \leq 0$ sehingga pada jawaban FAG masih terdapat variabel $x^{2}$, seharusnya variabel tersebut sudah tidak ada karena sudah dikurangkan dengan variabel yang sejenis. FAG yakin bahwa perhitungannya tersebut sudah benar sehingga dapat disimpulkan bahwa FAG kurang memahami operasi aljabar.

Sementara itu, WA terdeteksi mengalami miskonsepsi perhitungan di soal butir 3 
Vol 2 No 2 Desember 2021

Jurnal AlphaEuclidEdu

Received: 21/12/2020; Resived: 24/08/2021; Accepted: 31/12/2021

serta 5. WA menyelesaikan soal butir 3 serta 5 dengan cara yang benar, tetapi pada soal nomor 3 terdapat kesalahan menghitung yaitu $x-4-(x+6)=2 x-10$, seharusnya $x-4-$ $(x+6)=-10$. Kemudian pada soalnomor 5 terdapat kesalahan menghitung yaitu $2 x+4-$ $(3 x+6)=10-x$, seharusnya $2 x+4-(3 x+6)=-x-2$. Sedangkan WA yakin bahwa perhitungannya sudah benar. Hal ini disebabkan karena penalaran yang WA milikiketika mengerjakan soal tidak lengkapsehingga menimbulkan miskonsepsi. Darijawaban WA pada nomor 3 dan 5 menandakan bahwa WA kurang memahami operasi aljabar.Dari tabel 6 memberikan informasi bahwa sebanyak 3 siswa yaitu FT, NB, dan RAS mengalami miskonsepsipenspesialisasian. FT dan NB terdeteksimengalami miskonsepsi di soal butir 6. FT dan NB menyelesaikan soal butir 6 dengan menggunakan salah satu aturan atau sifatpertidaksamaan linear satu variabel seperti $x-20<80$ menjadi $x-20+20<80+$ 20 dan hasil akhirnya $x<100$, sedangkan soal yang diberikan adalah soal pertidaksamaan nilai mutlak. Jawaban seharusnya ialah $x-20<80$ menjadi $-80<x-20<80$ dan hasil akhirnya $-60<x<100$. FT dan NB menyamakan cara penyelesaian soal pertidaksamaan nilai mutlak dengan soal pertidaksamaan linear satu variabel sehingga dapat disimpulkan bahwa FT dan NB kurang memahami konsep nilai mutlak. Hal ini disebabkan oleh penalarannya ketika menyelesaiakn soal tersebut tidak lengkap.

Siswa dengan kode RAS terdeteksi miskonsepsi penspesialisasian di nomor 4. RAS menyelesaikannya dengan menggunakan salah satu sifat pertidaksamaan nilai mutlak "Jika $|x| \leq a$ maka $-a \leq x \leq a$ ". Jawaban RAS yakni $|x+1| \leq|x|$ dirubah menjadi $-x \leq x$ $+1 \leq x$. Padahal sifat tersebut tidak sesuai untuk digunakan dalam menyelesaikan soal nomor 4. Seharusnya $|x+1| \leq|x|$ kedua ruasnya dikuadratkan sehingga menjadi $|x+1|^{2} \leq$ $|x|^{2}$. RAS menyamakan cara penyelesaian soal pertidaksamaan nilai mutlak linear satu variabel yang memuat 1 kurung mutlak dengan soal pertidaksamaan nilai mutlak linear satu variabel yang memuat 2 kurung mutlak sehingga dapat disimpulkan bahwa RAS kurang memahami konsep nilai mutlak.

\section{Simpulan dan Saran Simpulan}

Menurut uraian di atas diperoleh kesimpulan bahwa terdapat lima bentuk miskonsepsi siswa dalam menyelesaikan soal pertidaksamaan linear satu variabel yang memuat nilai mutlak di kelas X SMA Muhammadiyah 1 Pontianak yaitu miskonsepsi notasi sebanyak 1 siswa, penggeneralisasian sebanyak 3 siswa, pengaplikasian aturan sebnayak 6 siswa, perhitungan sebanyak 2 siswa, serta penspesialisasian sebanyak 3 siswa. Selain itu, disimpulkan juga bahwa penyebab miskonsepsi yang dialami siswa ialah intuisi yang salah dan reasoning yang tidak lengkap, dimana pemikiran intuisi siswa yang muncul secara spontan saat menyelesaikan soal masih salah dan penalaran atau logika siswa yang masih salah dalam mengambil kesimpulan serta terlalu luas dalam menggeneralisasi. Intuisi yang salah dan reasoning yang tidak lengkap ini diduga terjadi karena siswa kurang memahami konsep nilai mutlak, kurang memahami sifat-sifat pertidaksamaan, dan kurang memahami operasi aljabar sehingga pemahaman siswa terhadap materi yang diajarkan tidak lengkap.

\section{Saran}

Menurut hasil penelitian, peneliti menyarankan: (1) alangkah baiknya untuk peneliti selanjutnya meneliti materi lainnya yang lebih kompleks seperti materi persamaan atau pertidaksamaan kuadrat agar penelitian mengenai identifikasi miskonsepsi dalam menyelesaikan soal nilai mutlak selanjutnya lebih berkembang; (2) bagi penelitiselanjutnya, sebaiknya meneliti miskonsepsi dengan menggunakan alat pengumpulan data yang lebih canggih lagi seperti tes diagnostik yang terdiri dari empat tingkatan (four-tier diagnostic test) karena alat tersebut dapat mendeteksi bentuk miskonsepsi dan penyebab miskonsepsi 
Vol 2 No 2 Desember 2021

Jurnal AlphaEuclidEdu

Received: 21/12/2020; Resived: 24/08/2021; Accepted: 31/12/2021

lebih akurat dari two-tier diagnostic test; dan (3) bagi pendidik, sebaiknya penyampaian mengenai konsep nilai mutlak lebih diperjelas lagi dan dicek kembali apakah siswa sudah memahami materi prasyarat.

\section{Referensi}

Depdiknas. 2006. Peraturan Menteri Pendidikan Nasional Republik Indonesia tentang Standar Isi untuk Satuan Pendidikan Dasar dan Menengah. Jakarta: Depdiknas.

Firdaus, H. 2017. "Tujuan pembelajaranMatematika di Sekolah Dasar". https://www.blogbarabai.com/2017/09/ tujuan-pembelajaran-matematikadi.html\#: :text=Tujuan\%20pembelajar $\quad$ an\%20matematika\%20di\%20sekolah\% 20dasar\%20secara\%20umum\%20adala $\quad$ h\%20agar,penataran\%20nalar\%20dala m\%20penerapan\%20matematika.\&text =Memecahkan\%20masalah\%2C\%20m elakukan\%20penalaran\%2C\%20dan\% 20mengomunikasikan\%20gagasan\%20 secara\%20matematika. Diakses pada 19 Agustus 2020 pukul 16.00 WIB. Ibrahim, Febrian, \& Ramadhona, R. 2020. Miskonsepsi Siswa dalam Menyelesaikan Soal PertidaksamaanNilai Mutlak Linear Satu Variabeldengan Menggunakan Three Tier Test. Student Online Journal. 1(1): 529-538.

Isyam, Y. A. N. 2019. Identifikasi Miskonsepsi Siswa dalam Menyelesaikan Soal TIMSS Konten Aljabar Ditinjau dari Tingkah Kecemasan Matematika. Kadikma. 10(1):74-84.

Purwanti, P. 2019. "Miskonsepsi Siswa pada Materi Operasi Hitung Bentuk Aljabar Di Kelas VII SMP Kemala Bhayangkari”. Skripsi. FKIP. Pendidikan Matematika. Universitas Tanjungpura. Pontianak.

Ramadhan, M., Sunardi, \& Kurniawati, D. 2017. Analisis Miskonsepsi Siswa dalam Menyelesaikan Soal Matematika Berstandar PISA dengan Menggunakan Certainty of Response Index (CRI). Kadikma. 8(1): 145-153.

Ramadhani, W. H. 2014. "Miskonsepsi Siswapada Materi Operasi Bentuk Aljabar Di Kelas VII SMP Haebat Islam Kubu Raya". Skripsi. FKIP. Pendidikan Matematika. Universitas Tanjungpura. Pontianak.

Rohmah, Z., \& Handhika, J. 2018. Two-Tier Test Diagnostic sebagai Identifikasi Miskonsepsi Tahap Awal Materi Kinematika Gerak Lurus Siswa Kelas X MAN 1 Kota Madiun. Prosiding Seminar Nasional Quantum. ISSN:2477-1511.

Sinaga, Bornok. 2017. Buku Guru Matematika SMA/SMK/MAK Kelas X. Buku Sekolah Elektronik (BSE). Jakarta: Pusat Kurikulum dan Perbukuan, Balitbang, Kemendikbud.

Suparno, P. 2013. Miskonsepsi \& Perubahan Konsep dalam Pendidikan Fisika. Jakarta: Grasindo.

Tayubi, Y. R. 2005. Identifikasi Miskonsepsi pada Konsep-Konsep Fisika Menggunakan Certainty of Response Index (CRI). Mimbar Pendidikan. 24(3): 4-9. 

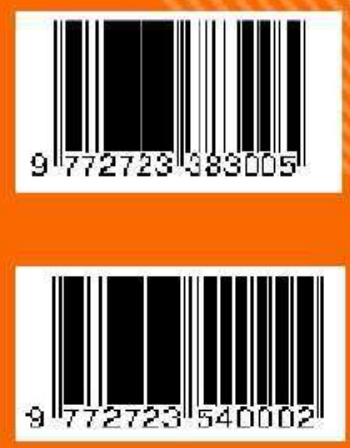